\title{
A TAXONOMIC REVISION OF THE GENUS STICHERUS (GLEICHENIACEAE - PTERIDOPHYTA) IN THE NEOTROPICS
}

\author{
Dissertation \\ zur Erlangung des Doktorgrades \\ der Mathematisch-Naturwissenschaftlichen Fakultäten \\ der Georg-August-Universität zu Göttingen
}

\author{
vorgelegt von \\ Maria Jasivia Gonzales Rocabado \\ aus La Paz, Bolivien
}

Göttingen, den 26.05.2003 
D7

Referent: Prof Dr. S.R. Gradstein

Korreferent: PD Dr. M. Kessler

Tag der mündlichen Prüfung: 


\section{DISCLAIMER}

The nomenclatural changes proposed in the text are not intended to be formal proposals. They will be valid in the published versions of the dissertation. 
Content

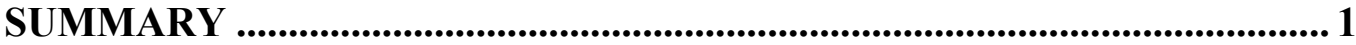

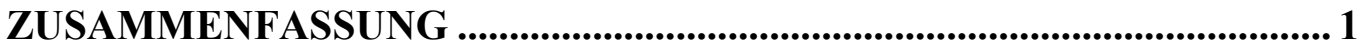

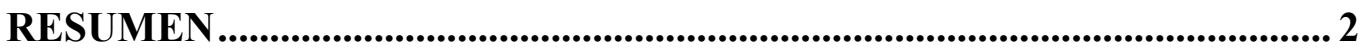

INTRODUCTION AND TAXONOMIC HISTORY ..................................... 3

Key to the genera of Gleicheniaceae ........................................................................5 5

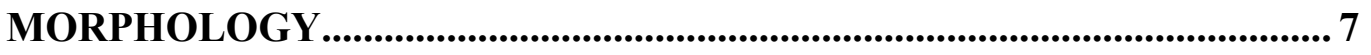

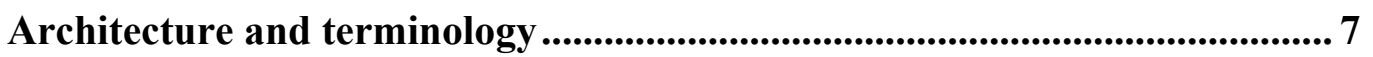

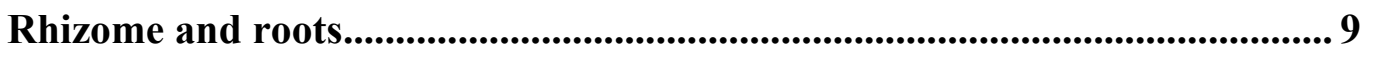

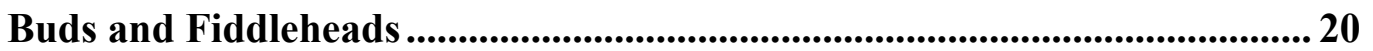

Sori, sporangia, and spores ............................................................................ 22

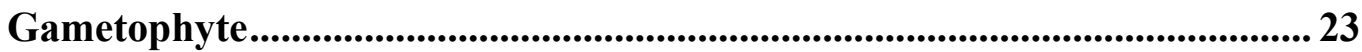

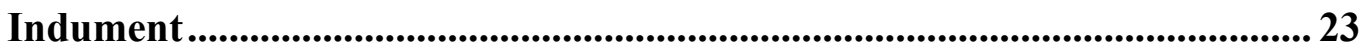

SPECIES CONCEPT AND HYBRIDIZATION........................................29

INTRAGENERIC RELATIONSHIPS ........................................................... 31

SYSTEMATIC TREATMENT ............................................................................. 34

Key to the Neotropical species of Sticherus and some of the interspecific

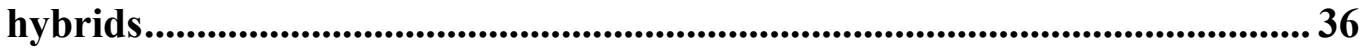

1. Sticherus bifidus (Willd.) Ching ............................................................. 43

2. Sticherus decurrens (Raddi) J. Gonzales, comb. nov ............................... 46

3. Sticherus ferrugineus (Desv.) J. Gonzales, comb. nov............................ 48

4. Sticherus cubensis (Underw.) J. Gonzales, comb. nov. ........................... 50

5. Sticherus chocoensis J. Gonzales, sp. nov ............................................ 51 
6. Sticherus interjectus (Jermy and T. Walker) J. Gonzales, comb. nov...... 56

7. Sticherus nigropaleaceus (J. W. Sturm) J. Gonzales, comb. nov. ............ 58

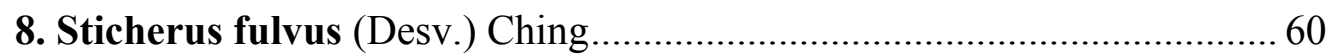

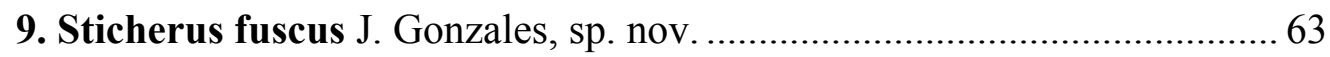

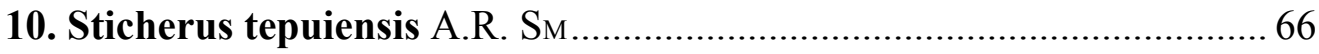

11. Sticherus aurantiacus Østergaard \& B. Øllgaard ................................. 68

12. Sticherus maritimus (Hieron.) Nakai................................................... 70

13. Sticherus rufus J. Gonzales \& A. R. Sm sp. nov. .................................. 71

14. Sticherus arachnoideus Østergaard \& B. Øllgaard................................ 74

16. Sticherus lanosus (H. Christ) J. Gonzales, comb. nov. ........................... 82

17. Sticherus hispaniolensis J. Gonzales, sp. nov....................................... 84

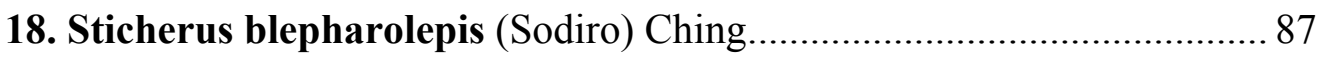

19. Sticherus jacha J. Gonzales, sp. nov .................................................... 90

20. Sticherus velatus (Kunze) Copel......................................................... 93

21. Sticherus squamosus (Fée) J. Gonzales, comb. nov. ............................. 95

22. Sticherus lanuginosus (Fée) Nakai.......................................................... 97

23. Sticherus compactus (H. Christ) Nakai................................................ 100

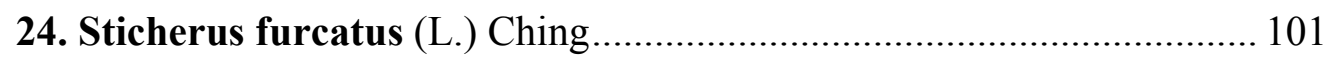

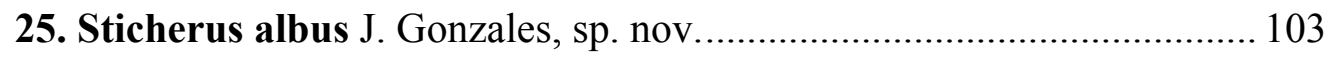

26. Sticherus pallescens (Mett.) Vareschi .................................................. 106

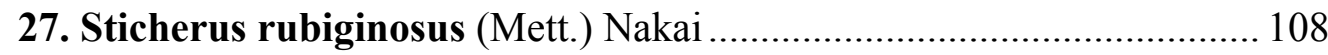

28. Sticherus brittonii (Maxon) Nakai ...................................................... 110

29. Sticherus farinosus (Kaulf.) J. Gonzales, comb. nov........................... 111

30. Sticherus strictissimus (H. Christ) Copel........................................... 113

31. Sticherus remotus (Kaulf.) Chrysler. .................................................. 114

32. Sticherus melanoblastus (Alston) Østergaard \& B. Øllgaard............... 116

33. Sticherus peruvianus (Maxon) A. R. Sm., M. Kessler \& J. Gonzales.. 118

34. Sticherus revolutus (Kunth) Ching ……............................................ 119

35. Sticherus nervatus J. Gonzales, sp. nov............................................. 122

36. Sticherus pruinosus (Mart.) Ching...................................................... 125

37. Sticherus underwoodianus (Maxon) Nakai.......................................... 127

38. Sticherus jamaicensis (Underw.) Nakai ............................................... 129

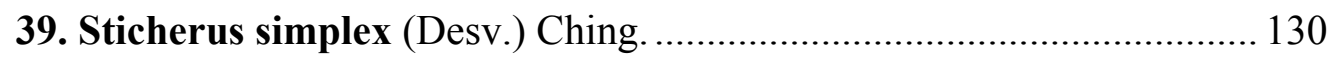

41. Sticherus boliviensis (Maxon \& C.V. Morton) J. Gonzales comb. nov.133 
42. Sticherus longipinnatus (Hook.) Ching ........................................... 135

43. Sticherus nudus (Moritz) Nakai ........................................................... 136

44. Sticherus ovatus J. Gonzales, sp. nov….............................................. 139

45. Sticherus brevitomentosus Østergaard \& B. Øllgaard ........................ 141

46. Sticherus pteridellus (H. Christ) Copel............................................. 143

47. Sticherus hypoleucus (Sodiro) Copel............................................... 144

48. Sticherus gracilis (Mart.) Copel. ......................................................... 146

49. Sticherus gnidioides (Mett.) Nakai.................................................... 148

50. Sticherus retroflexus (J. Bommer ex H. Christ) Copel......................... 149

51. Sticherus orthocladus (H. Chist) Chrysler......................................... 151

52. Sticherus hastulatus (Rosenst.) Nakai ................................................ 152

53. Sticherus intermedius (Baker) Chrysler ............................................ 153

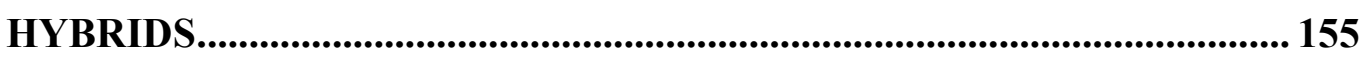

54. Sticherus x pseudobifidus (Jermy \& T. Walker) J. Gonzales, comb. nov. 155

55. Sticherus $x$ subremotus (Jermy \& T. Walker) J. Gonzales, comb. nov.156

56. Sticherus $x$ leonis (Maxon) J. Gonzales, comb. nov. 158

57. Sticherus gnidioides (Mett.) Nakai x Sticherus pteridellus (H. Christ)

Copel. 159

58. Sticherus hypoleucus (Sodiro) Copel. x Sticherus remotus (Kaulf.)

Chrysler 159

59. Sticherus ferrugineus (Desv.) J. Gonzales x Sticherus furcatus (L.) Ching 160

61. Sticherus melanoblastus (Alston) Østergaard \& B. Øllgaard x Sticherus tomentosus (Cav. ex Sw.) A.R. Smith 160

62. Sticherus simplex (Desv.) Ching x Sticherus revolutus (Kunth) Ching161 


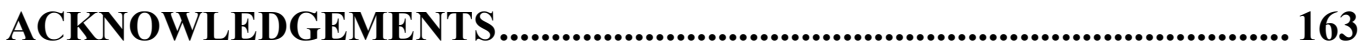

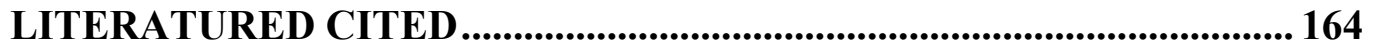

INDEX OF SCIENTIFIC NAMES...................................169 


\section{FIGURE CAPTIONS}

Fig. 1 Schematic representation of the branching arquitecture of Sticherus and the terminology used here. 8

Fig. 2. Rhizomes of Sticherus species......................................10

Fig. 3. Rhizome scales of Sticherus species..................................12

Fig. 4. Pinna arquitecture of Sticherus species.............................15

Fig 5. Abaxial axis and segment surface of Sticherus species.................17

Fig. 6. Abaxial axis and segment surface of Sticherus species..................18

Fig 7. Abnormal, monstruous specimens of Sticherus........................19

Fig 8. Aphlebiae, buds, and fiddleheads of Sticherus.......................21

Fig. 9. Scale shape of Sticherus.........................................25

Fig. 10. Shape of midvein and veinlet scales-abaxial surface of segments of Sticherus..............................................................26

Fig. 11. Mixed cell texture of the scales and several different patterns of cell hardening in Sticherus..................................................28

Fig. 12. Sticherus chocoensis J. Gonzales sp. nov., a) abaxial axis scales; b) bud scales, c1) midvein scales; c2) adaxial axis scales; d) arachnoid scales ; Fernández, García \& Velayos 8515 (holotype, BM)

Fig. 13. Sticherus fuscus J. Gonzales sp. Nov.............................67

Fig. 14. Sticherus rufus J. Gonzales \& A. R. Smith sp. Nov...................76 
Fig.15. Scale length and width of axis (a), bud (b), and midvein (c) scales of five closely related species in Sticherus tomentosus...........................82

Fig. 16. Sticherus hispaniolensis J. Gonzales, sp. Nov........................89

Fig. 17. Sticherus jacha J. Gonzales, sp. Nov ..............................95

Fig. 18. Sticherus albus J. Gonzales, sp. nov...............................108

Fig 19. Sticherus nervatus J. Gonzales, sp. nov.........................127

Fig. 20. Sticherus ovatus J. Gonzales, sp. nov..............................143 


\section{Summary}

Sticherus (Gleicheniaceae, Pteridophyta) is a pantropical genus of about 95 species, characterized by dormant buds with scales, 1-forked veinlets in the segments, (2)3-5(7) sporangia per sorus, and pinnatifid or pinnate ultimate axes. Its taxonomic history, morphology, and intrageneric relationships are discussed. In the Neotropics, I recognize 53 species and nine hybrids. Eight species are described as new: S. albus J. Gonzales, S. chocoensis J. Gonzales, S. fuscus J. Gonzles, S. hispaniolensis J. Gonzales, S. jacha J. Gonzales, S. nervatus J. Gonzales, S. ovatus J. Gonzales, and S. rufus J. Gonzales \& A.R. Smith. The following new combinations are proposed: S. boliviensis (Maxon \& C.V. Morton) J. Gonzales, S. cubensis (Underw.) J. Gonzales, S. decurrens (Raddi) J. Gonzales, S. farinosus (Kaulf.) J. Gonzales, S. ferrugineus (Desv.) J. Gonzales, S. lanosus (H. Christ) J. Gonzales, S. nigropaleaceus (J. W. Sturm) J. Gonzales, S. squamosus (Fée) J. Gonzales, S. x interjectus (Jermy and T. Walker) J. Gonzales, S. x leonis (Maxon) J. Gonzales, S. x pseudobifidus (Jermy \& T. Walker) J. Gonzales, and $S$. x subremostus (Jermy \& T. Walker) J. Gonzales.

\section{Zusammenfassung}

Sticherus (Gleicheniaceae, Pteridophyta) ist eine pantropische Farngattung mit ca. 95 Arten. Sie ist durch schuppenbesetzte Ruheknospen in den Gabelwinkeln, einfach geteilte Blattnerven in den Segmenten, (2)3-5(7) Sporangien pro Sorus, und einfach gefiederte bis fiederschnittige Achsen gekennzeichnet. Ihre taxonomische Geschichte, Morphologie und intragenerische Verwandtschaften werden diskutiert. Ich erkenne 53 Arten und neun Hybriden in den Neotropen an. Acht Arten werden neu beschrieben: $S$. albus J. Gonzales, S. chocoensis J. Gonzales, S. fuscus J. Gonzales, S. hispaniolensis J. Gonzales, S. jacha J. Gonzales, S. nervatus J. Gonzales, S. ovatus J. Gonzales und S. rufus J. Gonzales \& A.R. Smith. Die folgenden acht neuen Kombinationen werden vorgeschlagen: S. boliviensis (Maxon \& C.V. Morton) J. Gonzales, S. cubensis (Underw.) J. Gonzales, S. decurrens (Raddi) J. Gonzales, S. farinosus (Kaulf.) J. Gonzales, $S$. ferrugineus (Desv.) J. Gonzales, S. lanosus (H. Christ) J. Gonzales, S. 
nigropaleaceus (J. W. Sturm) J. Gonzales, S. squamosus (Fée) J. Gonzales, S. x interjectus (Jermy and T. Walker) J. Gonzales, S. x leonis (Maxon) J. Gonzales, $S$. x pseudobifidus (Jermy \& T. Walker) J. Gonzales und S. x subremostus (Jermy \& T. Walker) J. Gonzales.

\section{Resumen}

Sticherus (Gleicheniaceae, Pteridophyta) es un género pantropical con aproximadamente 95 especies. Está caracterizado por tener yemas cubiertas de escamas, segmentos con vénulas una vez divididas, (2)3-5(7) esporangios por soro, y los ejes distales pectinados-pinnatifidos o pinnatisectos. Se discute su historia taxonómica, morfología y sus relaciones intregenéricas. En el Neotrópico yo reconocozco 53 especies y nueve híbridos. Ocho especies son descritas como nuevas: S. albus J. Gonzales, S. chocoensis J. Gonzales, S. fuscus J. Gonzales, $S$. hispaniolensis J. Gonzales, S. jacha J. Gonzales, S. nervatus J. Gonzales, S. ovatus J. Gonzales y S. rufus J. Gonzales \& A.R. Smith. Además propongo las siguientes nuevas combinaciones: S. boliviensis (Maxon \& C.V. Morton) J. Gonzales, S. cubensis (Underw.) J. Gonzales, S. decurrens (Raddi) J. Gonzales, S. farinosus (Kaulf.) J. Gonzales, S. ferrugineus (Desv.) J. Gonzales, S. lanosus (H. Christ) J. Gonzales, S. nigropaleaceus (J. W. Sturm) J. Gonzales, S. squamosus (Fée) J. Gonzales, S. x interjectus (Jermy and T. Walker) J. Gonzales, S. x leonis (Maxon) J. Gonzales, $S$. x pseudobifidus (Jermy \& T. Walker) J. Gonzales y $S$. x subremostus (Jermy \& T. Walker) J. Gonzales. 


\section{Introduction and Taxonomic history}

The family Gleicheniaceae is an ancient, distinctive fern family easily recognized by its pseudodichotomous branching pattern with periodically or permanentely dormant laminar buds at the fork of a pair of axes. The family contains 5 genera, Diplopterygium (Diels) Nakai with about 25 species of which only one is widespread in tropical America, Dicranopteris Bernh. with 12 species of which four occur in the Neotropics, Gleichenella Ching with one Neotropical species, Gleichenia J. E. Smith with about ten species confined to the Old World, and Sticherus C. Presl of pantropical distribution with about 90 species of which 54 are found in the Neotropics. The family Gleicheniaceae is a conspicuous element of disturbed habitats, e.g., roadsides, landslides and sometimes agricultural areas, specially in humid montane habitats, but a few species also regularly occur in lowland forest and inside closed forests.

The first species of Gleicheniaceae today placed in Sticherus was described by C. Linnaeus in 1759 as Acrostichum furcatus L. In 1793 J.E. Smith established the genus Gleichenia J. Sm. to include all species today placed in the family Gleicheniaceae. Two further genera, Mertensia Willd. (Willdenow, 1804) and Dicranopteris Bernh. (Bernhardi, 1806) were soon erected to accomodate the species of Gleicheniaceae with hairs instead of scales and twice-forked or more divided veins. However, the name Mertensia had already been used by Roth in 1797 for a genus in the Boraginaceae and cannot therefore be applied in the Gleicheniaceae. The distinction between a scaly or hairy indument is of great importance in the family and has been used by most researchers working on the family to define two major groups. In 1836, C. Presl described the genus Sticherus C. Presl to include the scaly species with pectinate (not bipinnate) leaves and relatively flat segments on which the sori are located on the lamina surface (rather than hidden in grooves as in Gleichenia). However, the genus Sticherus was not widely accepted and most species today placed in this genus were originally described under either Gleichenia, Mertensia, or Dicranopteris. Indeed, in 1844 W.J. Hooker described Gleichenia subg. Mertensia Hook. whose circumscription follows that of Sticherus. This subgenus thus did not correspond to the delimitation of Mertensia as defined by Willdenow. Further genera described in the Gleicheniaceae are Calymella C. Presl (1836), Gleicheniastrum C. Presl 
(1848), Mesososrus Hassk. (1856), Hicriopteris C. Presl (1851), Gleichenella Ching (1940), Acropterygium (Diels) Nakai (1950), and Diplopterygium Nakai (1950).

The circumscription of genera within the Gleicheniaceae has varied widely between authors (Tab. 1). Diels (1900) placed all species in only one genus with several subgenera and sections. This classification was essentially followed by Christensen (1905), who, however, named the subgeneric taxa sections and subsections. Underwood (1907) separated the family into a neotropical genus (Dicranopteris) and a paleaeotropical one (Gleichenia). This classification is not consistent with morphological characters and has not been followed by other authors. In 1947, Copeland recognized four genera in the family, while three years later Nakai (1950) recognized seven. Neither of them used subgeneric species groups. Holttum (1957) returned to a broader generic concept, accepting two genera and six subgenera, a classification that was followed by Tryon \& Tryon (1982). Kramer (1990), in the last work to consider the family as a whole, in turn accepted four genera. It should be noted that the different concepts of the various authors not only referred to the taxonomic rank given to specific species groups, but also to the way in which such groups were delimited. Thus, some species were placed in different taxonomic groupings by different authors, the most obvious being Underwood's geographical genus delimitation. A full description of these problems, which mostly do not involve species of Sticherus, would be beyond the scope of this study.

Recent floristic treatments (Moran, 1995; Østergaard \& Øllgaard, 2001) essentially follow Kramer's (1990) classification, except for Østergaard \& Øllgaard (2001) treating Gleichenella as distinct from Dicranopteris. Given the marked morphological differences between these two genera, this classification is also followed here. However, it appears that all classifications of the Gleicheniaceae provided to date are partly artificial and more detailed studies are clearly needed for defining natural species groups within the family. Ongoing molecular studies by C. Pryor and others should provide a necessary background for a thorough generic revision of the Gleicheniaceae in the near future. It therefore appears to be premature to provide detailed descriptions of the genera. With these caveats in mind, a preliminary key to the genera of Gleicheniaceae is provided below. 


\section{Key to the genera of Gleicheniaceae}

1 Dormant buds with hairs; veinlets 2- to 4-forked; sporangia ca.

8-25 per sorus.

2 Pinnae furcations equal or nearly so, with a pair accessory, pinnatifid pinnae at the base of each proximal furcation Dicranopteris

2 Pinnae furcations unequal, lacking a pair of accessory pinnae Gleichenella

1 Dormant buds with scales; veinlets simple or 1-forked; sporangia

(2)3-5(7) per sorus.

3 Veinlets simple; segment margins strongly revolute, segments appearing channelled; ultimate segments 3-15 mm long Gleichenia

3 Veinlets 1-forked; segment margins flat to moderately revolute, segments flat; ultimate segments 5-50 mm long.

4 Ultimate axes bipinnate Diplopterygium

4 Ultimate axes pinnatifid or once pinnate Sticherus

Previous taxonomic treatments of Sticherus in the Neotropics are limited to local and regional floras, e.g., Sturm (1859) for Brazil, Sodiro (1893) for Ecuador, Underwood (1907) mostly for Mesoamerica, Vareschi (1969) for Venezuela, Stolze (1976) for Guatemala, Duek (1976) for Cuba, Smith (1981) for Chiapas, Mexico, Proctor (1985) for Jamaica, Smith $(1985,1995)$ for Venezuela, Mickel \& Beitel (1988) for Oaxaca, Mexico, Lellinger (1989) for Costa Rica, Panama and the Colombian Chocó, Tryon \& Stolze (1989) for Peru, Ortega (1991) for Portuguesa, Venezuela, Palacios-Ríos (1992) for Veracruz, Mexico, Moran (1995) for Mesoamerica, and Østergaard \& Øllgaard (2001) for Ecuador. 
Tab. 1. Comparison of the taxonomic arrangements of the Gleicheniaceae by various authors (modified after Holttum, 1957). Note that Stromatopteris Mett. is here considered be in a separate family, Stromatopteridaceae, while Platyzoma R. Br. is now placed in the Pteridaceae (Tryon \& Tryon, 1982; Kramer 1990). Both genera were included in Gleicheniaceae by several of the authors listed below.

\begin{tabular}{|c|c|c|c|c|c|c|}
\hline Diels (1900) & Christensen (1905) & Copeland (1947) & Nakai (1950) & Holttum (1957) & Kramer (1990) & This study \\
\hline Gleichenia & $\begin{array}{l}\text { Gleichenia } \\
\text { sect. Eugleichenia }\end{array}$ & & & Gleichenia & & \\
\hline subg. Eu-Gleichenia & subsect. Gleicheniastrum & Gleichenia & Gleichenia & subg. Gleichenia & Gleichenia & Gleichenia \\
\hline subg. Eu-Gleichenia & subsect. Protogleichenia & Gleichenia & Gleichenia & subg. Gleichenia & Gleichenia & Gleichenia \\
\hline $\begin{array}{l}\text { subg. Eu-Gleichenia } \\
\text { subg. Mertensia }\end{array}$ & $\begin{array}{l}\text { subsect. Calymella } \\
\text { sect. Dicranopteris }\end{array}$ & Gleichenia & Calymella & subg. Gleichenia & Gleichenia & Gleichenia \\
\hline sect. Diplopterygium & subsect. Diplopterygium & Hicriopteris & Hicriopteris & subg. Diplopterygium & Diplopterygium & Diplopterygium \\
\hline sect. Holopterygium & subsect. Holopterygium & Sticherus & Sticherus & $\begin{array}{l}\text { subg. Mertensia } \\
\text { Dicranopteris }\end{array}$ & Sticherus & Sticherus \\
\hline sect. Heteropterygium & subsect. Heteropterygium & Dicranopteris & Dicranopteris & subg. Dicranopteris & Dicranopteris & Dicranopteris \\
\hline sect. Heteropterygium & subsect. Heteropterygium & Dicranopteris & Gleichenella & subg. Dicranopteris & Dicranopteris & Gleichenella \\
\hline sect. Acropterygium & subsect. Acropterygium & Dicranopteris & Acropterygium & subg. Acropterygium & Dicranopteris & Dicranopteris \\
\hline
\end{tabular}




\section{Morphology}

\section{Architecture and terminology}

The most striking feature of the family Gleicheniaceae in general and the genus Sticherus in particular is its unique pseudodichotomously divided architecture and indeterminate leaf growth. During leaf development, the main axis deriving from the rhizome, i.e., the petiole, eventually branches, forming two lateral pinnae and a temporarily dormant apical bud. Once the pinnae are fully developed, the apical bud grows on, forming the rachis, which eventually undergoes the same process of bifurcation and bud-production. This process is repeated over and over again, potentially forming a leaf several meters long with many layers of pinnae that are all similar to each other. The pinnae in turn usually undergo several further hierarchical pseudodichotomous branching events and finally form segments on the distal axes and sometimes also on the axes one or two branching hierarchies below. The number of divisions of the pinnae is usually fairly consistent within a given species, but may vary even within a single pinna. Each bifurcation has a dormant bud that generally is not activated (Holttum, 1957; Punetha, 1988). However, when the main axis is damaged, the pinna axes may increase their growth.

This branching pattern and the resulting architecture, with a variable number of pseudichotomies and the homogeneous appearance of divisions of different order, make it impractical to use the traditional terms applied to the hierarchy of branching. This problem was already addressed by Underwood (1907), Wagner (1952), and other earlier workers, but it was Holttum (1957) who coined a suitable descriptive terminology that was expanded upon by Østergaard \& Øllgaard (1996) (Fig. 1). here use this terminology with a few modifications. The axes within a pinna were named branches by Østergaard \& Øllgaard. However, by definition, branches are leafbearing axes attached to a stem, while in the present case, the entire structure starting from the rhizome is a single leaf. I thus refrain from using the term branch for a structure within a leaf and prefer the term axis. Axes in turn can be annotated hierarchically, i.e., $1^{\text {st }}$ axis, $2^{\text {nd }}$ axis, etc., starting from the petiole or rachis. This order corresponds to that of Underwood (1907) but differs from that of Østergaard \& Øllgaard in that their $1^{\text {st }}$ order axis starts after the first bifurcation of the pinna, rather than at the base of the pinna. The ultimate branches of Østergaard \& Øllgaard are 


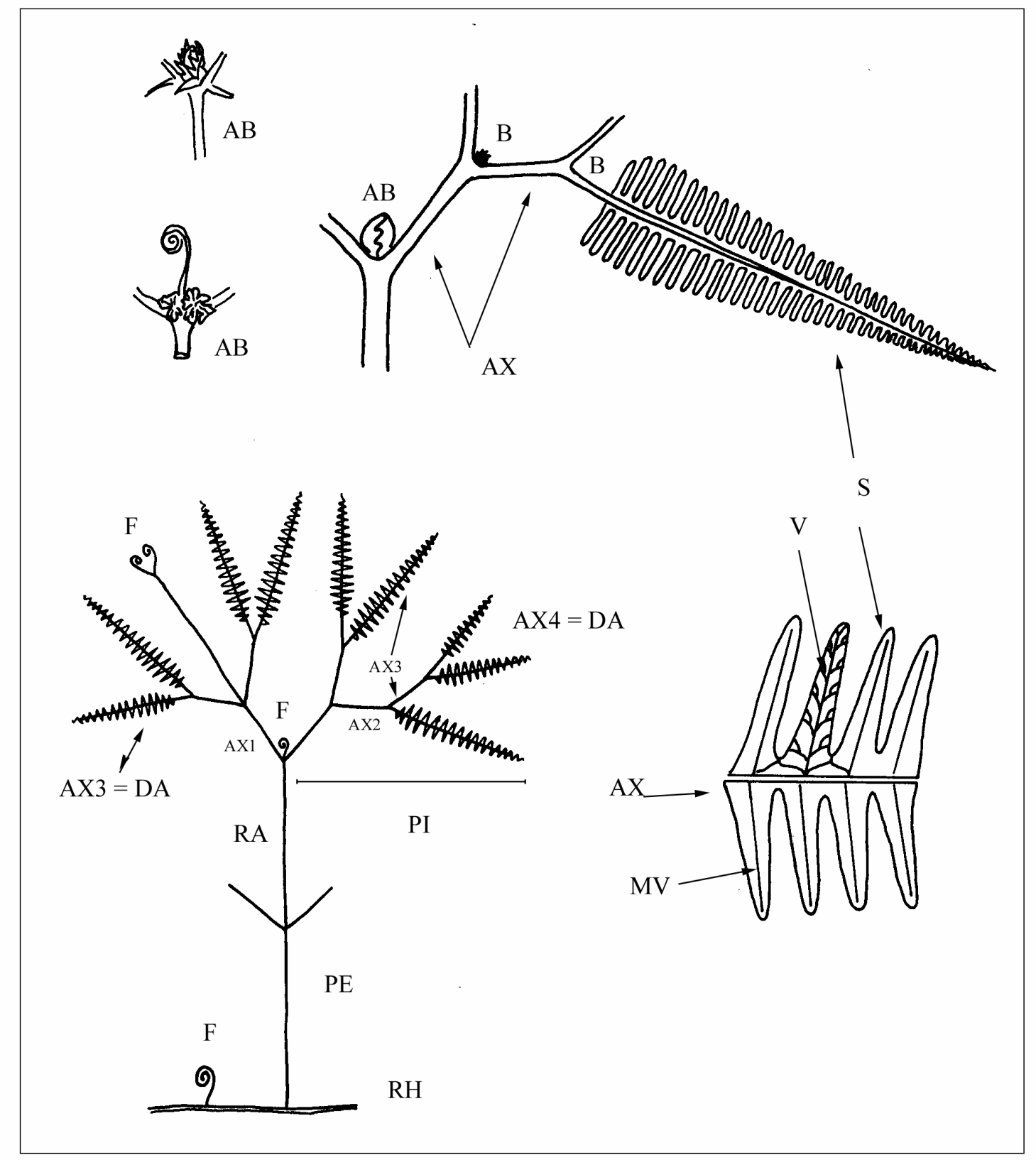

Fig. 1. Schematic representation of the branching arquitecture of Sticherus and the terminology used here. $\mathrm{AP}=$ aphlebiae, $\mathrm{AX}=$ axes (of different branching hierarchy), $\mathrm{B}=$ bud, $\mathrm{DA}=$ distal axis, $\mathrm{F}=$ fiddlehead, $\mathrm{M}=$ midvein, $\mathrm{PE}=$ petiole, $\mathrm{PI}$ $=$ pinna, $\mathrm{RA}=$ rachis, $\mathrm{RH}=$ rhizome, $\mathrm{S}=$ segment, $\mathrm{V}=$ veinlet. Modified after Østergaard \& Øllgaard (1996). 
here called distal axes. The buds of the rachis and the lateral axes were differentiated by Østergaard \& Øllgaard into rachis buds for those of the rachis, and dormant buds for those of the lateral axes. Due to the general similarity of these buds and the difficulty of recognizing these different buds in the frequently fragmentary herbarium material, I simply call them buds. In some cases, however, it may be convenient to distinguish between the distal buds, i.e., that of the ultimate axis division, and the proximal buds at a lower level of division. In addition to the term bud, I also employ the term fiddlehead for the young, unexpanded, circinate apex developing rachises or pinna axes, i.e., for growing buds (Lellinger, 2002). The foliaceous appendages borne on the acroscopic side between the rachis and the $1^{\text {st }}$ axis were named pseudostipules by Østergaard \& Øllgaard but are here called aphlebiae, following Heer (1875), who coined this term to refer to these structures in fossilized Gleicheniaceae.

\section{Rhizome and roots}

Rhizomes in Sticherus are short- to long-creeping, 1-10 mm in diameter (Fig. 2), and dichotomously forked. In some species, specially in larger ones, the rhizomes cover distances of up to 3-10 m, while in some shorter ones, e.g., S. retroflexus (Fig. $2 \mathrm{~b}$ ) and S. hypoleucus, the rhizomes are agglomerate, forming dense, intertwined masses. In all species the rhizomes are rooted superficially and where the plants form dense thickets, e.g., on landslides, the rhizomes of many individual plants mix to produce a dense net in the upper 3-5 $\mathrm{cm}$ of the soil. The vascular bundles are protostelic, i.e., they have a single ring of phloem surrounding a solid core of xylem (Chrysler, 1943).

The roots are radially arranged around the entire rhizome. Sometimes they are more numerous just after rhizome bifurcations, as is also the case with the leaves. The roots of two species of Sticherus and several other Gleicheniaceae were studied by Schneider (1996). They are 0.37-0.9 mm thick, with a central cylinder 0.16-0.22 $\mathrm{mm}$ in diameter. The rhizodermis consists of not differentiated, elongate cells and produces few root hairs. The cortex consists of a single-layered, sclerenchymatous hypodermis and 2-5 further cell layers. The wall thickness of theses layers decreases inwards, as does the intensity of the brown wall coloration. The sclereids of the hypodermis have a hexagonal outline, while those of the inner cortex are tangentially 


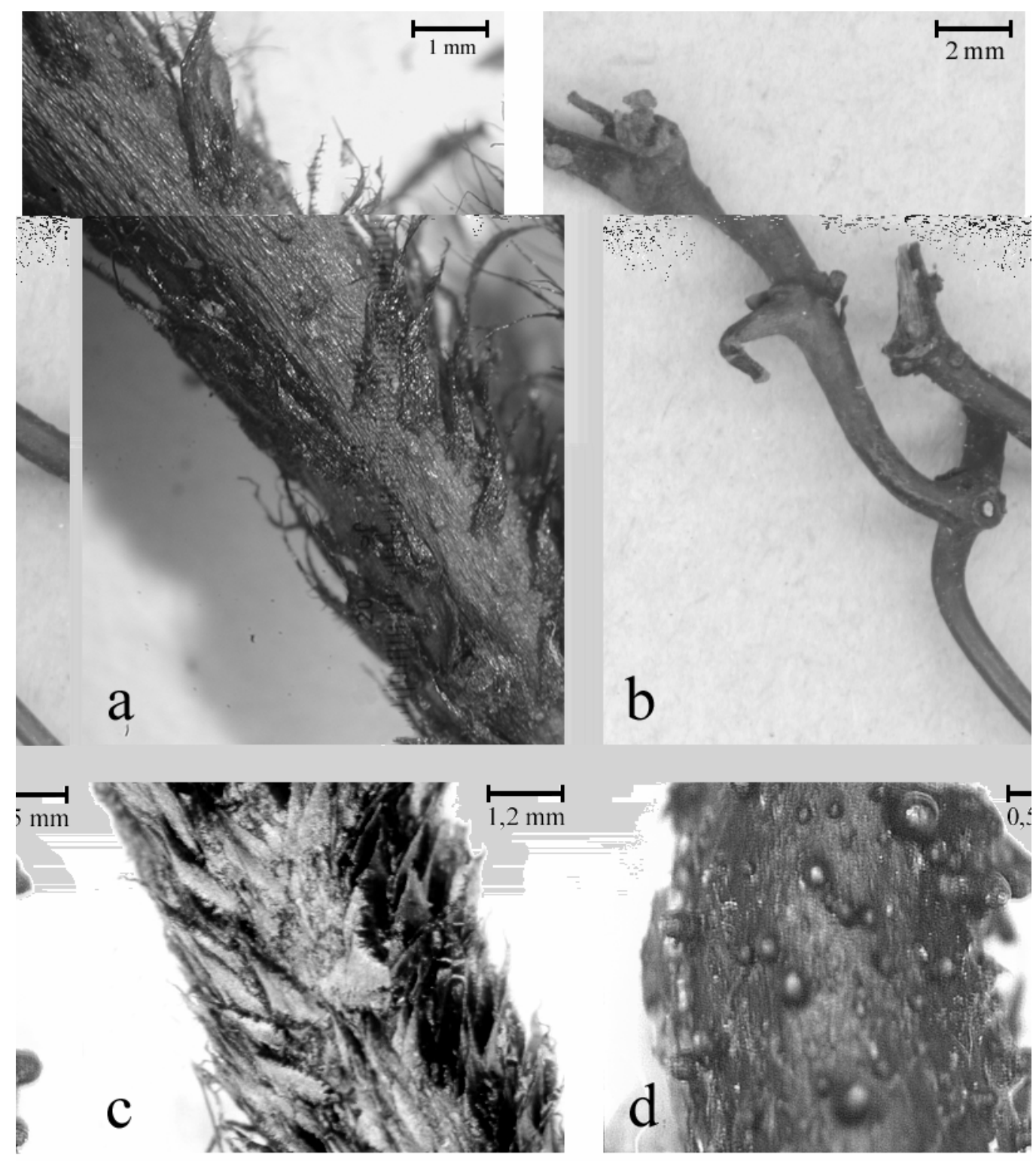

Fig. 2. Rhizomes of Sticherus species: a) deciduously scaly, S. ferrugineus (Gonzales 3407); b) glabrous, S. retroflexus (Gonzales 3426); c) densely scaly, S. tomentosus (Zogg \& Gassner 13667); d) with squamophores, S. melanoblastus (Østergaard 10823).

elongated and flat. The central cylinder is tri- or tertrarch, with 2-4 tracheids in the protoxylem, and 5-12 in the metaxylem. The pericycle is always single-layered.

Leaves are arranged along the entire rhizome, but they are more densely clustered just behind bifurcations (Hagemann \& Schulz, 1978). In larger species with long-creeping rhizomes, the leaves are usually about $10 \mathrm{~cm}$ apart, while in shorter ones with agglomerate rhizomes they may be only up to $2 \mathrm{~cm}$ distant from each 
other. The surface of the rhizomes is dark brown, reddish or orange in color, and usually rugose, scarred or muricate, but rarely also lustrous (Fig. 2a). Some species have squamophores (Fig. 2d), i.e., hump-like epidermal projections bearing the scales. In these case, when the scales are abraded, the rhizomes remain covered with abundant, short, blunt tubercles. The taxonomic value of the squamophores in Sticherus was first recognized by Østergaard \& Øllgaard (2001). All species of Sticherus bear scales on the rhizome (Fig. 2a, c), but in many species these are deciduous and hardly, if ever, found on herbarium material. The scales are generally lanceolate (Fig. 2a-d), ovate (Fig. 2e-f), rigid, dark brown to reddish orange, and have setose margins (Fig. 3a-b). Sticherus maritimus is unique on bearing a single apical gland on each rhizome scale (Fig. 2b). 


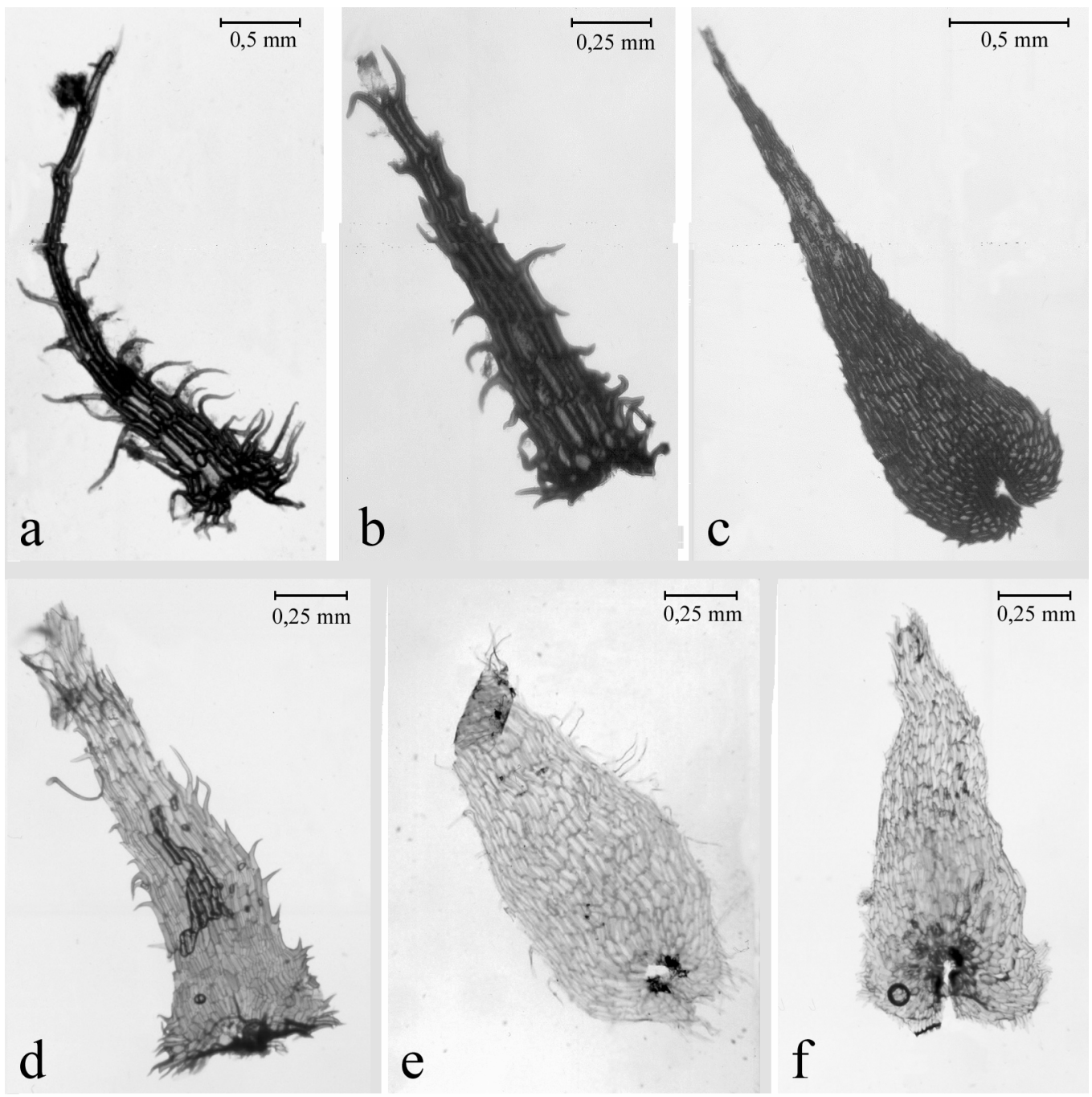

Fig. 3. Rhizome scales of Sticherus species: a) rigid scales, $S$. interjectus (Walker 10332); b) subclathrate with glandular apex, S. maritimus (Haught 5321); c) basally rounded with dentate margins, $S$. hypoleucus (Mickel 2235 b); d) stoutly hyaline, $S$. nudus (Grant 10757); e) ovate, hyaline, S. ovatus (Ariste 158), f) hyaline $S$. pteridellus (Gómez 7072). 


\section{Leaves}

The unique leaf architecture of Sticherus was described above (architecture and terminology). Briefly, the leaf consists of a central axis producing pairs of opposite lateral pinnae at regular intervals. The pinnae in turn are pseudodichtomously divided into axes that are usually unpectinate proximally and pectinate distally. All bifurcations bear dormant buds. The leaves have indeterminate growth but usually only reach 0.5-3 $\mathrm{m}$ in length, specially in open, sunny situations. Under shady forest conditions, however, plants may climb upwards by using their spreading pinnae as a support and the elongate rachis to reach higher levels (Wagner, 1988). The longest leaves documented in Sticherus are about $5 \mathrm{~m}$ in length, but other Gleicheniaceae are known to reach $30 \mathrm{~m}$ in length (Holttum, 1957).

The petiole is continuous, i.e., not articulate, as thick or somewhat thinner than rhizome, and terete to adaxially flattened. The vascular bundles are protostelic, forming a "C" with curved extremes (Chrysler, 1944). The petiole surface is crustaceous (hard, thin, and brittle) to cartilagineus (hard and tough) and pale orange to greenish. The petioles generally do not bear scales, but often they are subpaleaceous, i.e., on the base they have some scales resembling those of rhizome, even though they usually have a somewhat laxer consistence.

Beyond the proximal pinna pair, the central axis is called rachis. In diameter it is similar to or slightly more slender than the petiole. In some species, e.g., in $S$. tomentosus and its allies, the rachis bears some scales derived from the bud and fiddlehead (see there), in others, it is glabrous. Usually, the rachis bears aphlebiae at the pinna bases.

The pinnae are composed of hierarchically arranged axes. In some species, the pinnae are only once-forked, while in others, they may be up to six-forked. Only S. simplex is an exception, with simple, pectinate, leaves lacking lateral axes. The number of bifurcations is of taxonomic importance (Fig. 4a-d), but there is a certain degree of variation within a given species, e.g., from three- to five-forked in $S$. lanuginosus (Fig. 4b). The length of the axes varies within and between species. Important characters are provided by the length and thickness of the axes, and specially by the relative length of axes of different order, e.g., of the $1^{\text {st }}$ axis relative to the $2^{\text {nd }}$. In some species, e.g., S. tomentosus and S. compactus, the thick axes impart a robust appearance to the whole plant, while in others, e.g., S. aurantiacus, 
the very long distal axes are conspicuously longer than the proximal ones. Other important characters are provided by the angle between the axes. This angle is somewhat variable within a given plant and even more within a species, and is difficult to quantify, but strongly impacts the appearance of a plant (Fig. 4a-d). In some species, e.g., S.tomentosus (Fig. 4a), the angle is usually around $90^{\circ}$, while in others, e.g., S. lanuginosus (Fig. 4b), it is generally around $45^{\circ}$. In some species, the angle between the axes varies on a single pinnae. In S. revolutus, e.g., the proximal axes form angles of about $90^{\circ}$, while among the distal axes the angles are around $45^{\circ}$. Further characters are provided by the placement of the segments. All species have fully pectinate distal axes. The proximal axes usually lack segments, but in some species they bear scattered internal segments. The presence of segments on the intermediate axes is more variable and often of taxonomic significance. In some species, e.g., S. pteridellus, these axes lack segments, while in others, e.g., S. rufus, they are pectinate. There is some variation of this character within some species, however. The length and shape of the segments may provide a given axis with a distinctive outline. For example, S. rufus has linear axis outlines, S. tomentosus lanceolate outlines, and $S$. melanoblastus truncate-lanceolate outlines. The apices of the pectinate axes usually bear gradually reduced segments, but in some cases, there are conform apical segments. This variation, however, appears to take place mostly within species, and a single plant may have both extremes and intermediate cases. All the above characters provide the respective plants with characteristic appearances that, with experience, can be used for identification. In many herbarium specimens, however, the pinnae are incomplete and usually show only the distal axes, and careful examination is necessary to understand the architecture of the whole plant. Often, it is difficult even to decide if the lowermost axis visible on a herbarium sheet is the rachis or a proximal axis of the pinna. 

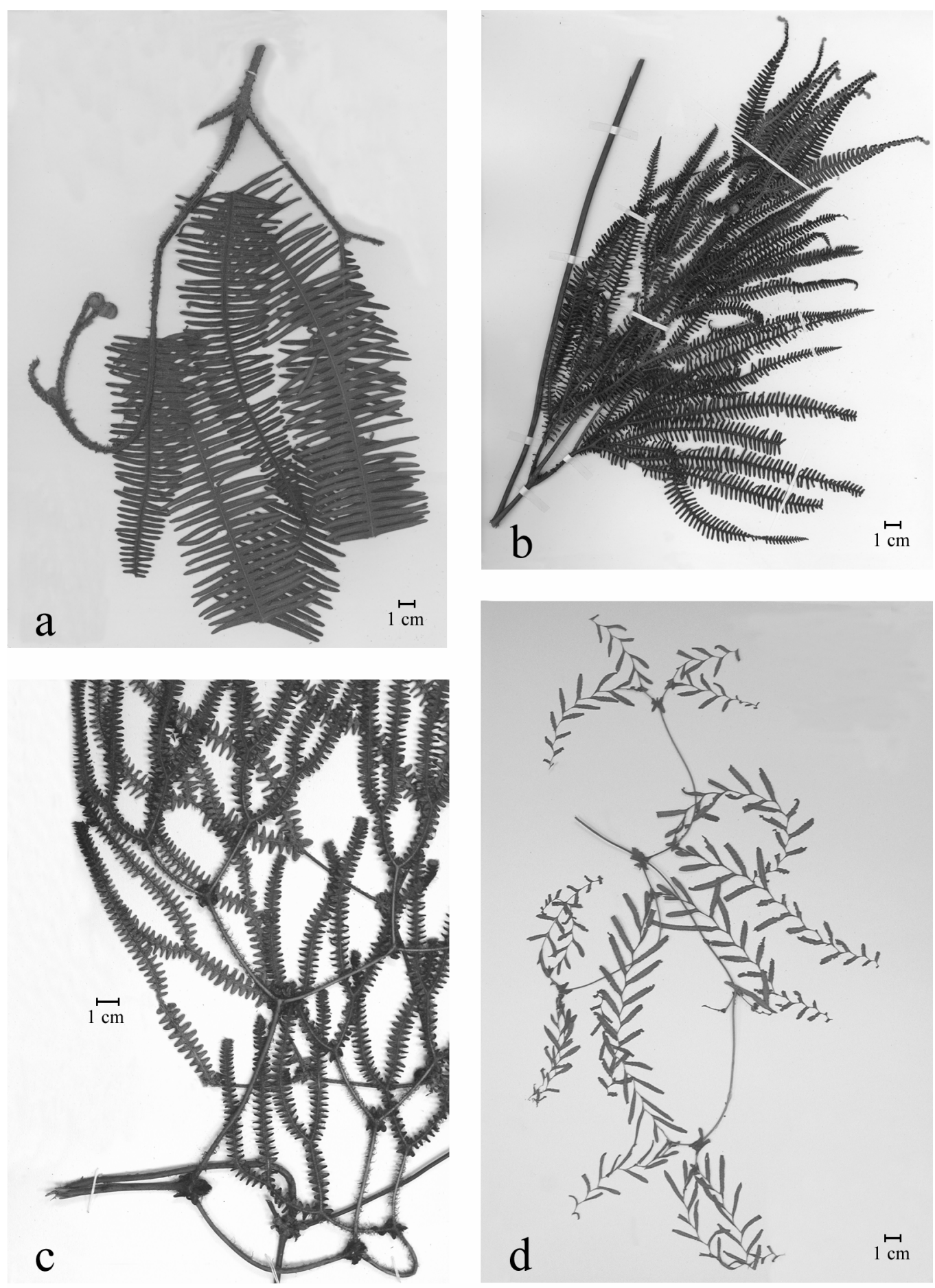

Fig. 4. Pinna arquitecture of Sticherus species: a) S. tomentosus (Luteyn 9734); b) S. lanuginosus (Pabst 7077); c) S. revolutus (Gonzales 3381); S. retroflexus (Beitel $77110)$. 
The segments on an axes may be arranged in a pinnatifid pattern, i.e., they are joined above the lowermost veinlet pair, deeply pinnatifid (Fig. 5a, c, f; 6c), i.e., joined below the lowermost veinlet pair, pectinate (Fig. 5b, d), i.e., fully separate or sometimes joined by a membranaceous ridge, or remote (Fig. 4d; 5e; 6e-f), i.e., fully separated along the axis. These arrangements may also be observed within a single plant, with the segments on proximal axes generally being more distant from each other than on the distal axes. This variability is specially pronounced in some hybrid specimens, e.g., S. interjectus.(Fig. 6a). The individual segments have different shapes. Sometimes they are acicular (Fig. 5a), i.e., gradually reduced from the base to the apex, linear, i.e., with parallel margins for most of the length, oblong, i.e., with narrowed bases (Fig. 5c, f), or triangular (Fig. 5d; 6c-d) to rounded (Fig. 5b) in species with partly or generally strongly reduced segments. The segment base may be adnate (Fig. 5 a-f; 6 a-d) to markedly hastulate (Fig. 6 e-f), i.e., widened specially acroscopically. The heteroblastic variation in segment shape and pinnule development has been described in detail in Dicranopteris linearis (Burm.) Underw. (Wagner, 1957; Bierhorst, 1971), and while no comparable studies exist for Sticherus, there certainly are many similarities between the genera. Occasionally, segments in Sticherus may be pectinate. Such monstruous forms have been interpreted by Holttum (1957) as a reversal to a more ancestral condition, suggesting that the simple segments of Sticherus are phylogenetically derived from more highly dissected segments as, e.g., in Diplopterygium. However, Maxon $(1909,1912)$ described a different monstruous form on S. bifidus from Jamaica (Fig 7a-b), in which the segments are reduced to crenate wings along the axes (Fig 7b). He also interpreted this as a reversal to an ancestral condition, in direct conflict with Holttum's (1957) hypothesis. Usually, the margins are entire, but in S. retroflexus and its allies there are undulate (Fig $4 d ; 6 e)$. Further, the margins are generally slightly to markedly revolute, but this appears to vary with segment age and environmental conditions. Older segments and segments from dry, sunny places are generally more coriaceous and have more strongly revolute margins. In many species, fertile segments are also more strongly revolute than sterile ones. In may species of Sticherus, the abaxial segment surface may show a bluish white, glaucuous wax cover. While it appears that some species never have this cover, there is no species in which it is always present, and it is therefore of limited taxonomic 
value. Apparently, its development is environmentally determined, possibly by high irradiation or drought, but this remains to be studied.
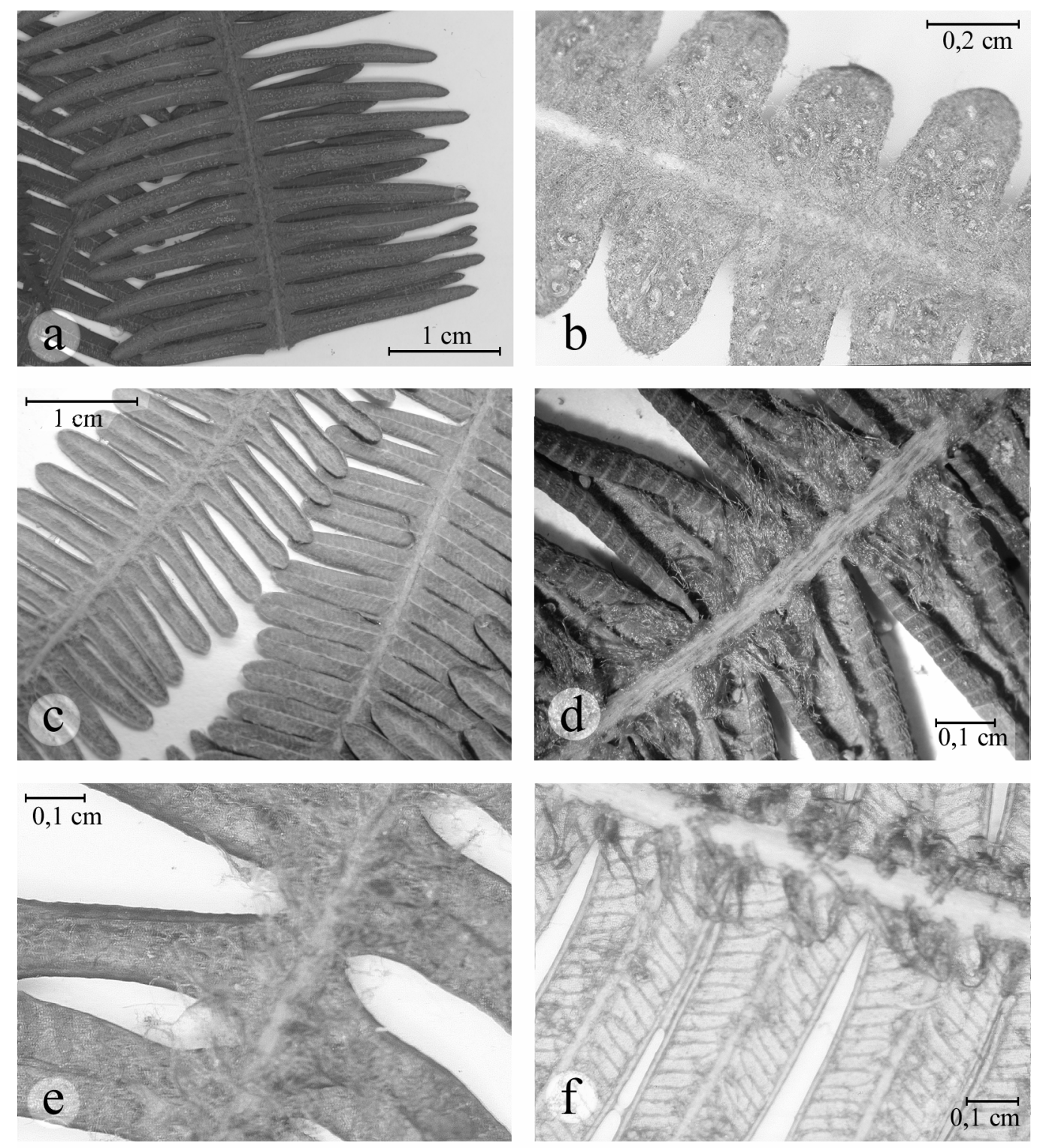

Fig 5. Abaxial axis and segment surface: a-c, densely scaly; d-f, only axis and midvein scaly: a) S. tomentosus (Luteyn 9734); b) S. maritimus (Haught 5321); c) S. arachnoideus (Øllgaard \& Navarrete 105775); d) S. revolutus (Grant 9427); e) S. boliviensis (Kessler 10614); f) S. rubiginosus (Alston 8192). 

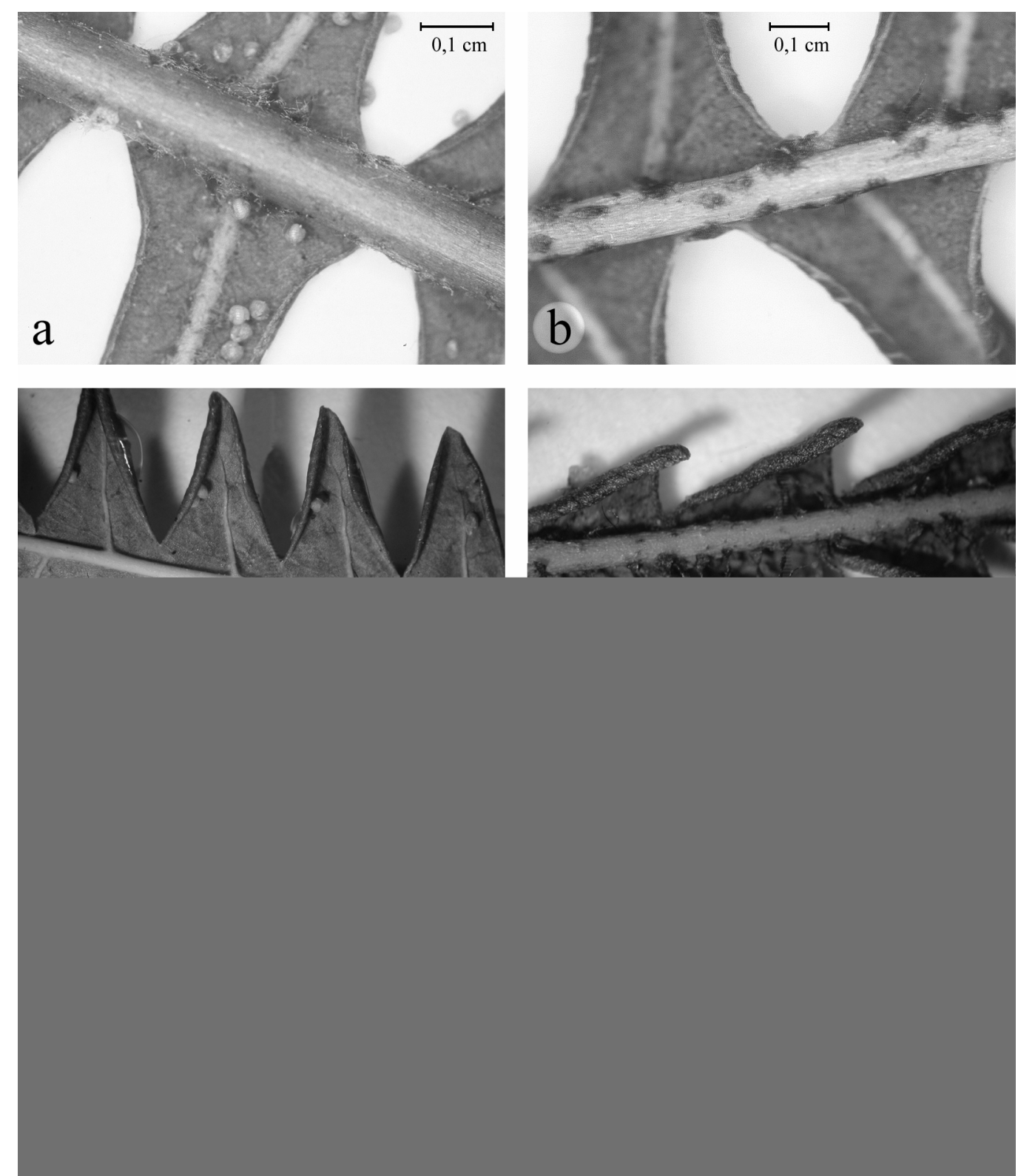

Fig. 6. Abaxial axis and segment surface: a-b, d, axes scatteredly scaly; c, e-f glabrous: a) S. interjectus (Walker 10332); b) S. pteridellus (Goméz 7072); c) S. hypoleucus (Mickel 2235 b); d) S. gnidioides (Palacios 6951); e) S. retroflexus (Gonzales 3426); f) S. hastulatus (Moran 4063). 

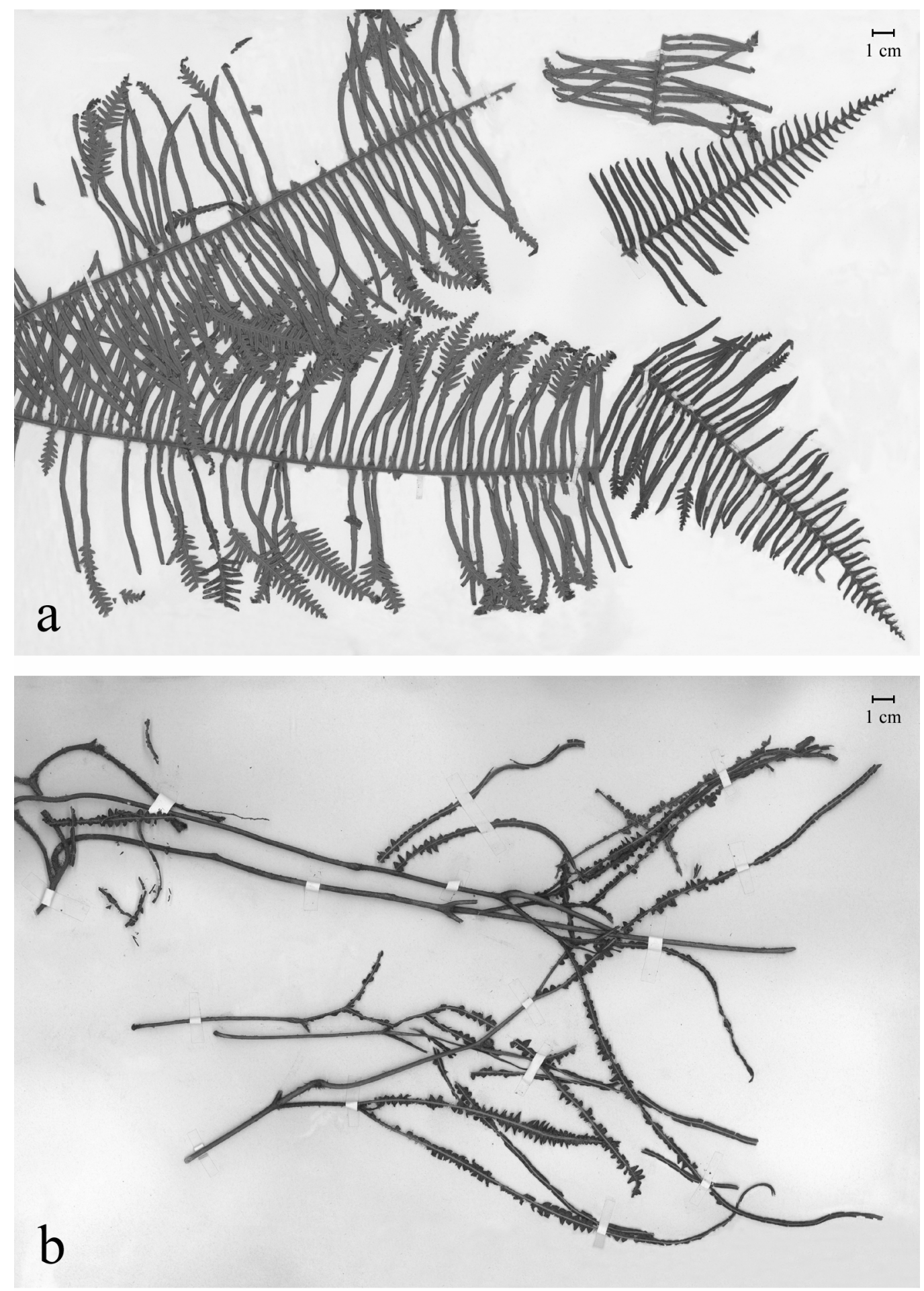

Fig 7. Abnormal, monstruous specimens of Sticherus: a) S. aff. bifidus, Guadalupe, 1843, L. Herminier s.n. (BM); b) S. aff. rubiginosus, presumably Colombia, Lehmann 1027 (NY).

The segment venation in Sticherus consists of an undivided midvein and once-forked lateral veinlets. The midvein is always rather thick and raised and usually is whitish. In contrast, the veinlets are much less pronounced. They are raised 
in some species and level with the lamina surface in others and their coloration varies from whitish to darker than the lamina. The veinlets are sometimes well-separated from each other and have divergent branches, while in other species they are closely spaced with pararllel branches. There is always a difference in the scale indument of the midvein and veinlets.

In some species of Sticherus, the abaxial lamina surface bears papillae, i.e., minute, round protuberances. In some species, e.g., S. farinosus, their presence is of taxonomic importance, but in others, e.g., S. lechleri and S. boliviensis, their presence appears to depend on environmental factors. Perhaps, leaves exposed to strong insolation develop papillae as a protective measure, but this remains to be studied.

Aphlebiae are present on many species of Sticherus. These foliaceous appendages protecting the dormant buds are borne on the acroscopic side of the pinnae between the rachis and the first axis (Fig. 1; 8a-d). They are usually best developed at the junction of the pinnae with the rachis, but may also be found on the proximal axis divisions. The presense or absense (Fig. 8e-f) of aphlebiae, and their shape and degree of dissection is of great taxonomic importance. They can be entire, forked, lobed, or pinnatifid. The term aphlebiae was coined to reffer to these structures in fossil Gleicheniaceae (Heer, 1875; Fount Quer, 1993). Other authors have called them Schutzfiedern (protective segments) (Troll, 1939), foliaceous appendages (Tryon \& Stolze, 1989), or pseudostipules (Østergaard \& Øllgaard, 1996).

\section{Buds and Fiddleheads}

Latent buds are borne between axes bifurcations and are often protected by aphlebiae (Fig. 8a, c-f). They are always covered in scales that may differ in shape, size, texture, and coloration from those of other organs of a plant and provide important taxonomic characters. The scales may be appressed, e.g., in S. bifidus, or spreading, e.g., in S. hypoleucus, and accordingly the appearance of the bud may vary considerably. Developing buds form fiddleheads, and these often provide much important information for identification. This is specially true on fragmentary herbarium material, where the fiddlehead may give clues as to the total pinna 
architecture and the density and type of the scale indument. These characters may be
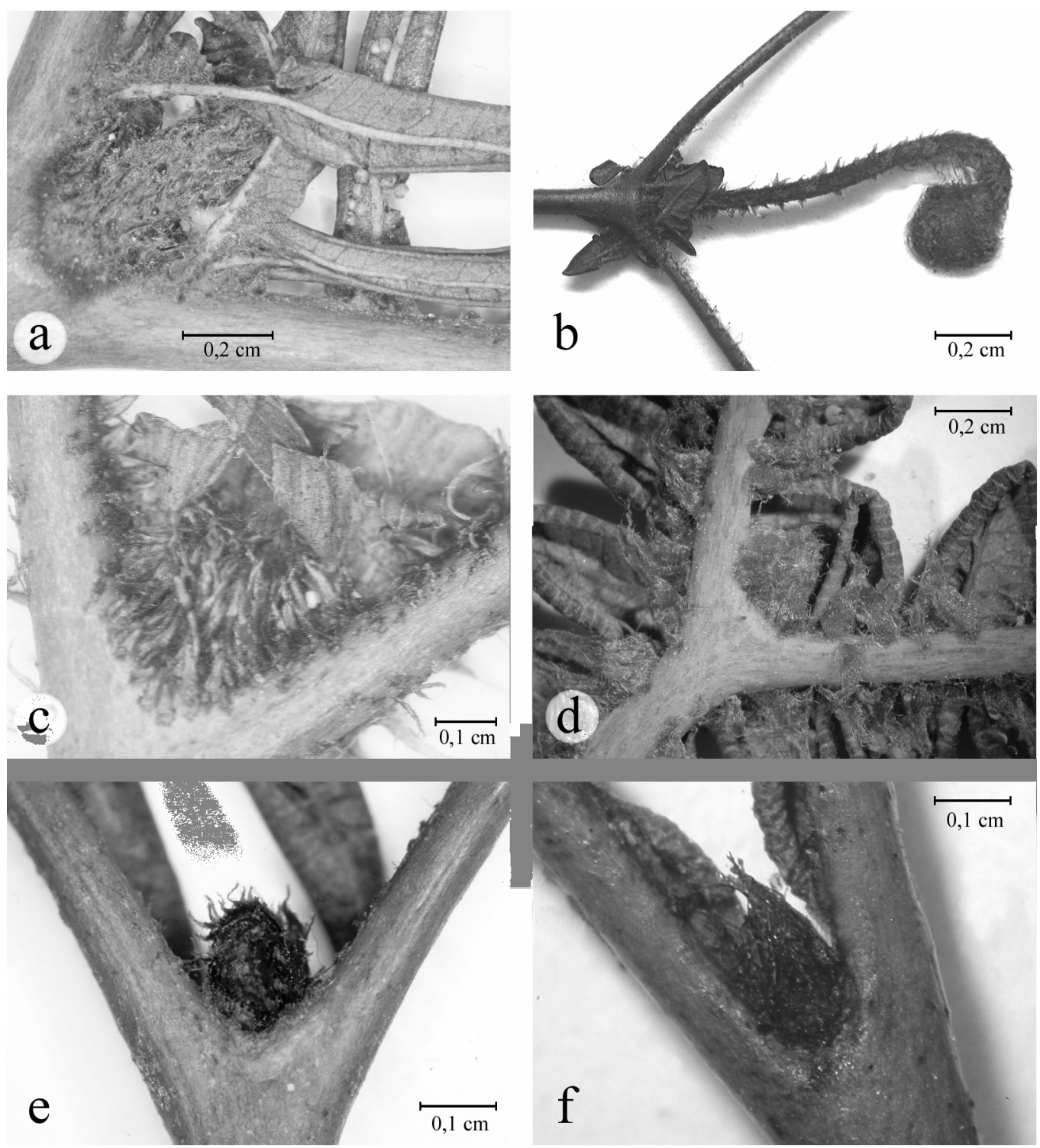

Fig 8. Aphlebiae, buds, and fiddleheads of Sticherus: a) trimerous, S. interjectus (Walker 10332); b) pinnatifid, S. revolutus (Gonzales 3615); c) simple, S. compactus (Smith 2255); d) simple, S. nervatus (Kessler 12113); e) aphlebiae lacking, $S$. tepuiensis (Steyenmark 109036); f) only with internal proximal segments, $S$. pteridellus (Triana s.n.).

difficult to assess on fragmentary specimens. The size of the fiddleheads is not always proportional to the size of the pinnae. In some species, e.g. S. bifidus, $S$. chocoensis, and S. interjectus, the fiddleheads are highly compressed and relatively short, while in others, e.g., S. maritimus and S. simplex, even young fiddleheads are disproportionately large. In general, it is important in the Gleicheniaceae to 
distinguish between the fiddleheads formed by entire develping leaves emerging from the rhizome, and fiddleheads formed by pinnae (Fig. 1) or the rachis (Fig. 1; $8 b)$.

\section{Sori, sporangia, and spores}

The sori of Sticherus are rounded and exindusiate. They are located on the basiscopic branch of the veinlets and may be inframedial to medial. They bear (2)35(7) sporangia per sorus. In some species, the sori are nested with groups of arachnoid scales. This is specially conspicuous in species with otherwise glabrous abaxial segment surfaces, e.g., S. blepharolepis and S. melanoblastus. According to Kramer \& Green (1990) in Gleicheniaceae the sori on a given segment develop simulataneously, but in many specimens of Sticherus it is evident that the proximal sori mature first and sometimes the distal ones fail to fully develop.

The sporangia of Sticherus bear an obliquous annulus with several illdefined stomium cells. The sporangial stalk is very short and consists of few cells.

The spores are ellipsoidal, 27-47 ?m long, and monolete with a linear apperture 2/3-3/4 the length of the spores (Tryon \& Lugardon, 1990). The surface is finely rugulate and usually perforate, but sometimes also finely granulate. The exospore consists of three layers between the apperture (Lugardon, 1971, cited in Tryon \& Lugardon, 1990) and the flange, while the perispore is thin with short, irregularly disposed rodlets (Tryon \& Lugardon, 1990). The perispore is brittle and readily detached from the exospore. The characteristic exospore structure with a middle layer is also found in Gleichenia and Dicranopteris in the Gleicheniaceae, as well as in Cheiropleuraceae, Dipteridaceae, Matoniaceae, and Stromatopteridaceae, and supports a basic relationship between these families. The homogeneity of the spores within Sticherus prevents their use for taxonomic purposes.

Germination experiments conducted with probably $S$. ferrugineus (presumably misidentified by the authors as S. bifidus, but no vouchers specimens have been seen) by Haufler \& Adams (1982), showed a marked decline of the germination capacity with spore age. Stored at room temperature, the percentage of germinating spores declined from $8-9 \%$ one week after deciscence to $0 \%$ after 11 weeks. Haufler \& Adams hypothesized that this short viability was due to the thin spore walls. 


\section{Gametophyte}

The morphology and development of the gametophytes has been described by Stokey (1950) and Haufler \& Adams (1982). Briefly, cell divisions following germination result in a three-dimensional mass of cells which secondarily initiates the two-dimentional thallus. This thallus is symmetrical, cordate, with a thick midrib and numerous red-brown rhizoids. Massive antheridia develop on both the dorsal and ventral sides of the thallus, about 10 weeks after sowing (Haufler \& Adams, 1982). At this time, multicellular trichomes develop near the meristematic region of the gametophyte. Archegonia with long, 8- to 10-celled necks are developed on the ventral surface just posterior to the notch region about two weeks later. At about 1 year of age, the inner portion of the gametophyte begins to die and cells along the margins of the wings often begin dividing such that three-dimensional cell masses are formed, which in turn develop typical, two-dimensional, cordate thalli. Stokey (1950), additionally observed filaments of cells after germination, an observation that was not corroborated by Haufler \& Adams (1982). Haufler \& Adams (1982) found no response of gametophyte development to antheridiogen A of Pteridium aquilinum (L.) Kuhn, antheridiogen B of Lygodium japonicum (Thunb.) Sw., and $\mathrm{GA}_{3}$.

The rather primitive gametophyte morphology and development pattern with initial three-dimensional stages of the Gleicheniaceae has been interpreted as supporting a basal placement of the family among the homosporous ferns (Atkinson \& Stokey, 1964; Haufler \& Adams, 1982).

\section{Indument}

The indument of Sticherus consists entirely of scales. These are highly variable and provide many of the most important characters for defining species and relationships between species (Holttum, 1957). Following Lellinger (2002) a scale is a multicellular, usually flat, lanceate or lanceolate to circular, basifixed, dorsifixed, or peltately attached outgrowth a few to typically many cells wide at the base, but sometimes one cells wide distally or at the apex. In Sticherus, one may occasionally find single-cell wide, branched structures that by definition would correspond to hairs, but as they show a continuous gradation towards the typical scales, I here call 
them scales. The distinction between hairs and scales, both of which are trichomes, i.e., epidermal outgrowths (Font Quer, 1993), is generally a gradual one.

Important characters to consider when describing scales are their size, shape, cell texture, and pattern of scale hardening, color, and placement on the plant.

The size of scales in Sticherus varies from $0.05 \mathrm{~mm}$ to $3 \mathrm{~mm}$. This variation is related to different species as well as to scale shape and the placement of the scales on a given but. The largest scales are usually found on the buds, and the shortest on the abaxial segment surface. The most constant sizes on a given plant and on specimens of a given species, are found on the axes and on the midvein, while on the buds the scale size can vary considerably depending on the development stage.

The shape of the scales can be linear, lanceolate, oval, ovate, orbicular, rhomboid, or triangular (Fig. 9a-h). The scale base can be truncate (Fig. 9a), rounded (Fig. 9b-c), sagitate (Fig. 3a), cordate (Fig. 3c, f), and auriculate (Fig. 3d), while the apex is aristate (Fig. 9c, d, f, h), mucronate, setose, long-aristate with a single apical hair (Fig. 9d-f)or a tuft (Fig. 9b) of several hairs (Fig. 9g), or with a single apical gland (Fig. 3b, 9e). The margins may either be entire or bear cilia, i.e., long, lax marginal outgrowths, or setae, i.e, short, stiff ones. These cilia and setae in turn vary in their length and thickness, and in whether they are straight or curved. In the species descriptions, I have expressed the length of these structures relative to the length of the entire scale. In Sticherus, there appears to be a general relationship between scale shape and the development of the margins. Ovate scales, e.g., in $S$. retroflexus, S. nudus, (Fig. 3e-f) and their allies, usually have entire margins, while lanceolate scales are generally ciliate or setose. In many cases, the scales are reduced to hair-like structures (Fig. 18 c2; 19c) (Holttum, 1957). In the most extreme cases, e.g., on the adaxial axis of $S$. revolutus, some of these consist of a simple linear arrangement of cells and would therefore correspond to hairs. However, there are always intermediate forms towards scales. Such intermediate forms are forked hairs or highly dissected scales with a minute scale body and long, linear outgrowths (Fig. 10a-h). Since all these forms are always found together on a given plant, a distinction between hairs and scales is inappropriate. Another type of scale reduction results in arachnoid scales that consist of a line of 2-10 globose cells on which each cells has a long outgrowth (Fig. 10i-1). 


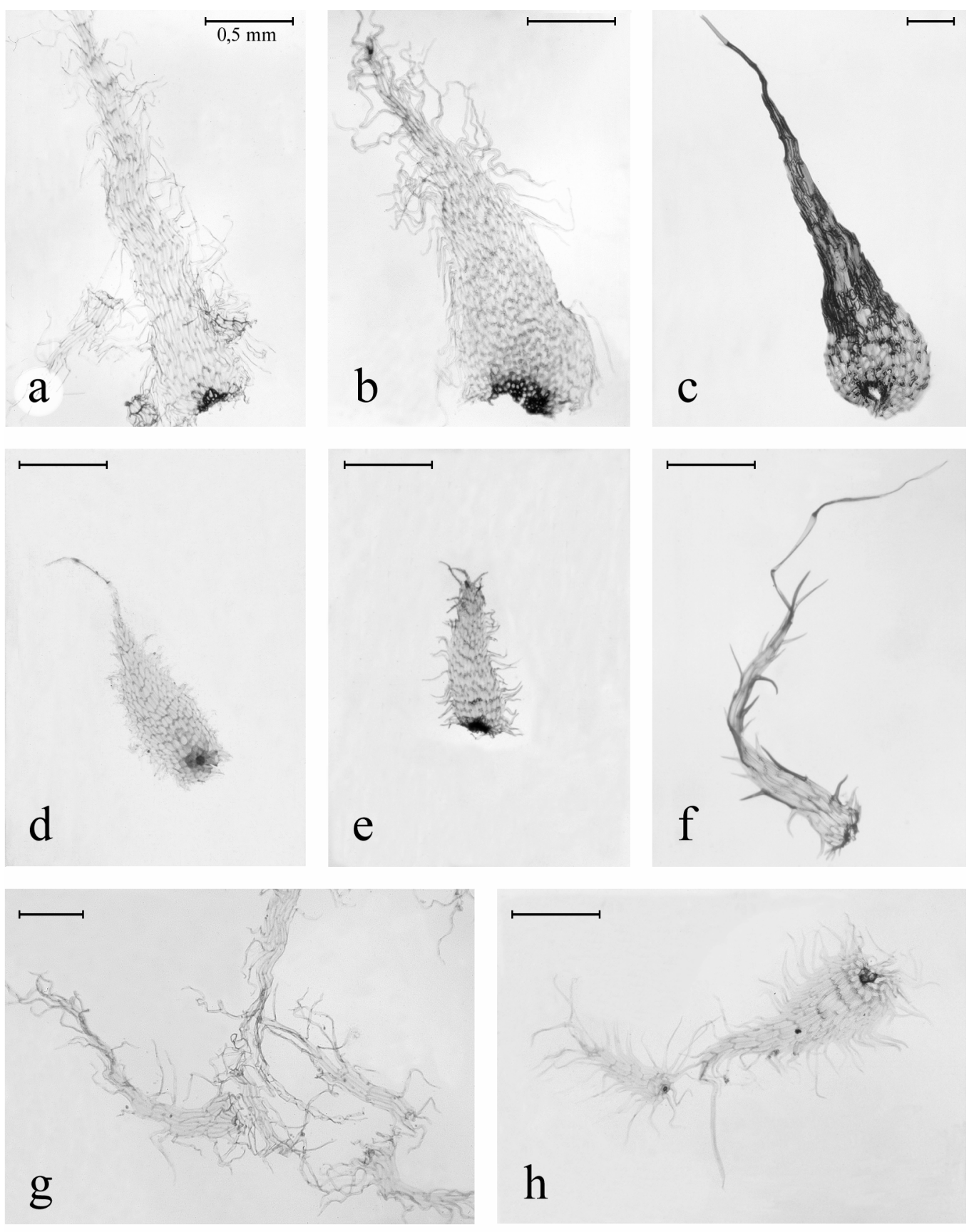

Fig. 9. Scale shape of Sticherus: a) bud scales narrowly lanceolate, S. ferrugineus (Hampshire \& Whinterfood 71), bud scales lanceolate, S. bifidus (Solomon 18884); bud scales subulate with entire margins, S. hypoleucus (Brade 503); d) abaxial axis scales ovate with an apical hair, S. pteridellus (Goméz 7072); e) bud scales lanceolate with glandular apices, S. maritimus (Haught 5321); f) abaxial axis scales linearlanceolate to filiform, S. longipinnatus (Tuomisto 5295); g) abaxial axes scales fimbriate, S. aurantiacus (Fay 2525); h) abaxial axis scales subulate with entire margins, S. interjectus (Walker 10332). 


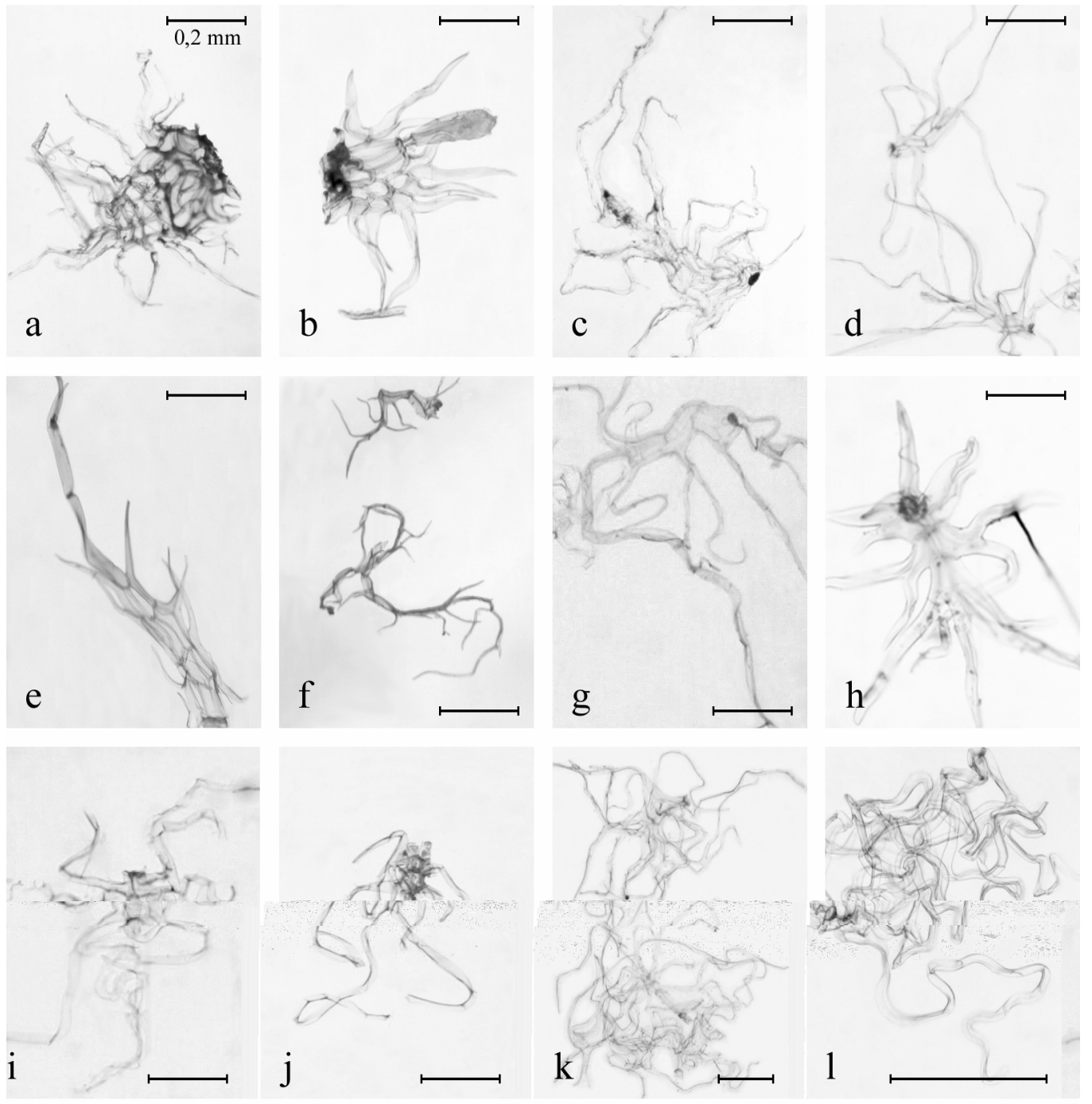

Fig. 10. Shape of midvein and veinlet scales (abaxial segments surface), a-c triangular scales, d-g linear scales: a) S. peruvianus (Asplund 13658); b) glandular scales, S. maritimus (Haught 5321); c) S. bifidus (Solomon 18884); d) S. ferrugineus (Hampshire \& Whinterfood 71); e) S. rubiginosus (Alston 8192); f) S. boliviensis (Smith \& Smith 13126); S. velatus (Mexia 4250B); h) veinlet scales star-shape, $S$. peruvianus (Asplund 13658); arachnoid scales: I) S. velatus (Mexia 4250B); j) S. tepuiensis (Steyenmark 109036); k) S. maritimus (Haught 5321); 1) S. bifidus (Solomon 18884).

The cell texture of the scales can vary from hyaline to rigid. For the species descriptions, the following terms have been used.

Hyaline scales have thin-walled, clear cells with translucent lumina, and are usually have a thickness of only one cell layer (Fig. 9a, b, d, e, g, h). The color varies 
from whitish to pale orange. The scales may or may not be well-defined, and sometimes have a grated appearance. These scales are usually lax and when they have ciliate margins they have a lanose appearance.

Stoutly hyaline scales have a thickness of two cell layers at the base and thus appear bicolorous (darker at the base, paler at the margins and apex) (Fig. 9c; 11a).

Rigid scales have the cell walls hardenened and dark-colored. Often, the lumina are filled with air and these bubbles also appear dark (Fig 3 a-c). Entirely rigid scales are mostly narrowly lanceolate and are typically found on the rhizomes.

Scales of mixed texture are partly hyaline and partly rigid (Fig. 11 a-i). There are several different patterns of cell hardening. In some cases, the hardening is limited to the scale margins, including the setae (Fig. 9f; 11h). In some cases, only parts of the scale margin are hardened (Fig. 11g), and then have setae, while the hyaline cell portion bears cilia. This is found, e.g., in S. rubiginosus, S.strictissimus, and $S$. compactus. Other species show hardened scale bases. Sometimes, e.g., in $S$. ferrugineus, S. palmatus, and S. peruvianus (Fig. $11 \mathrm{~b}-\mathrm{c}$ ), the hardening is limited to the base, while in other cases, e.g., in S. tomentosus and its allies, it may encompass most or even all of the scale. Yet another pattern consists of a central hardening, that may extend to the base (Fig. 11d). In some such species, e.g., S. aurantiacus and the bud scales of $S$. interjectus, the margins always remain clear, while in others, e.g., $S$. melanoblastus and $S$. tepuiensis, the margins become partly hardened but the base remains hyaline (Fig. 11e). In other species, e.g., S. rtemotus, S. nigropalleaceus, and S. decurrens, the hardening starts at the scale apex (Fig. 11f), extending onto the scale center, resulting in a scale with a dark, setose apex and a hyaline, ciliate base. Finally, there are species with a mosaic pattern (Fig. 11i), e.g., S. fulvus, where the cell hardening does not start from a defined area and extends from there, but rather occurs at several to many different parts of the scale, without a clear pattern. The patterns of cell hardening appear to be species specific and provide important characters for identification. It is always necessary to examine numerous scales on a given plant in order to locate scales of different degree of hardening and thereby understand the pattern involved. The most consistent patterns are usually found on the scales of the abaxial axis, and to a lesser degree on the bud. Hybrid specimens or species of hybridogenic origin may show mixed patterns of scale hardening. For example, S. interjectus, the allotetraploid offspring of $S$. ferrugineus and $S$. remotus, 
has basally hardened bud scales, as in $S$. ferrugineus, but apically hardened abaxial axis scales, as in $S$. remotus.
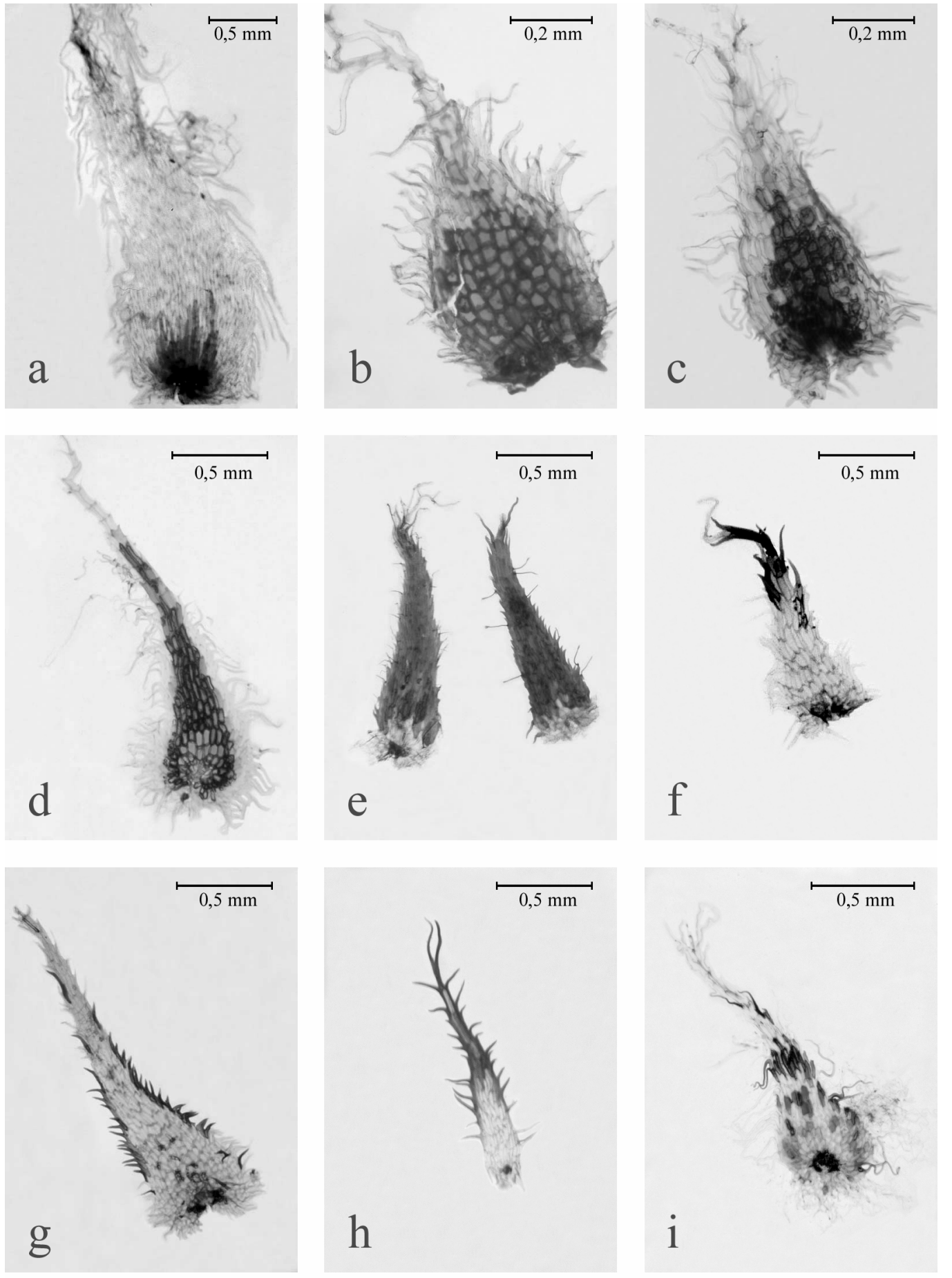

Fig. 11. Mixed cell texture of the scales and several different patterns of cell hardening in Sticherus. Hardened scale bases: a) bud scales, S. tomentosus (Ewan 16675); b) bud scales and c) abaxial axis scales, S. peruvianus (Asplund 13658); d) bud scales with central hardening, S. interjectus (Walker 10332); abaxial axis scales with hardened apices and margins, and hyaline bases, e) S. tepuiensis (Steyenmark 109036); f) with partly hardened margins, S. interjectus (Walker 10332); g) S. 
compactus (Valdespino 144); h) S. rubiginosus (Fay 2579); i) mosaic hardening pattern, S. fulvus (Watt 25).

In addition to the cell texture, there is also variation in the cell shape. This can vary from rounded, specially in ovate scales, to hexagonal and linear, specially in lanceolate scales.

Scale color is closely correlated to cell texture. Hyaline scales are whitish to pale orange, stoutly hyaline scales are bicolorous, and rigid scales are partly or wholly dark brown, depending on the pattern of cell hardening.

Scales are found in Sticherus on various parts of the plant. On the rhizome, they are usually lanceolate and rigid. The petiole is mostly glabrous, except at the base, where some scales similar to those of the rhizome are often found. The bud is always moderately to densely scaly. The scales are lanceolate to ovate and may be hyaline, rigid, or mixed. The abaxial axes may be glabrous to moderately scaly, with lanceolate to star-shaped, hyaline to mixed scales, while the adaxial side has hair-like to arachnoid scales. The midveins generally have scales, but in some rare cases may be glabrous. There is great variation in scale type, from variously lanceolate (rectangular, rhomboid, triangular) to star-shaped and fimbriate, and from hyaline to mixed. The scales of the abaxial segment surface are always similar to those of the adaxial axis in a given species, but are generally slightly less rigid. In some species, the abaxial segment surface is glabrous, while in others the scales are restricted to the immediate surroundings of the sori. The adaxial segment surface is generally glabrous, except in S. melanoblastus, which bears some archanoid and hair-like scales.

\section{Species concept and Hybridization}

I applied the Phylogentic Species Concept (Nelson \& Platnick, 1981; Nixon \& Wheeler, 1990; Luckow, 1995) based on morphological characters. A species is thus defined as the shortest aggregation of populations diagnosable by a unique combination of character states in comparable individuals (Nixon \& Wheeler, 1990). Among ferns, the application of species concepts is generally complicated by the special genetic traits among homosporous plants (Haufler, 2002) and the occurrence of various speciation mechanisms, e.g., hybridogenic speciation, polyploidy, and agamospory (Barrington et al., 1989; Gastony \& Windham, 1989). These 
mechanisms are often difficult to detect, leading to cryptic species that are morphologically almost alike but reproductively and evolutionarily independent (Paris et al., 1989). Elucidation of such complex systems requires in-depth biosystematic studies, ideally involving extensive chromosome counts, biochemical and/or molecular analysis, and hybridisation experiments, in addition to a thorough morphological analysis. The present study was based on an intensive study or macroand micromorphological characters. As such, the species delimitations proposed here are to be understood as hypothesis that may be subjected to testing once more data is available.

One of the main considerations in species delimitation was the recognition of hybrids. Hybridization and polyploidization within the Gleicheniaceae was documented by Sorsa (1968) who found chromosome numbers of $\mathrm{n}=20,22,34,56$, 68 in the genus Gleichenia (taken in the broad sense of Holttum, see Table 1). He interpreted these numbers as triploids, tretraploids, and hexaploids based on ancestral chromosome number of $\mathrm{n}=11$ and 17 . However, this study is limited to few species and of little help in understanding relationships within Sticherus. More detailed studies of reticulate speciation and hybridisation have been conducted in other fern genera, mainly in Europe and North America (e.g., Asplenium:Van der Heedee et al., 2003; Botrychium: Wagner \& Wagner, 1983; Isoetes: Hickey et al. 1989; Polystichum: Mullenniex \& Mester, 1999).

Hybridization appears to be a common phenomenon in Sticherus, but our knowledge about it is limited. The only study in this respect was conducted by Jermy \& Walker (1986) in Trinidad. In a detailed cytotaxonomic analysis they documented that the diploid parent taxa $S$. ferrugineus and $S$. remotus hybridised to produce the tetraploid $S$. interjectus. This species in turn recrossed with the parent taxa to form the sterile triploid hybrids $S$. x pseudobifidus (S. interjectus x $S$. ferrugineus) and $S$. x subremotus ( $S$. interjectus $\mathrm{x}$ S. remotus). The triploid hybrids are both quite variable morphologically, sometimes have darkened, presumably malformed spores, and have several striking features among the scales. Notably, the scales appear more crumpled (rather than flat as in the parent species), are more appressed to the surfaces, and have more irregular cell patterns. Also, the hardened scale portions are arranged in a more irregular pattern and do not follow the regular patterns visible in "good" species. These scale malformations presumably reflect the genetic incompatibility of the hybrids. 
It is important in this respect to distinguish two different forms and outcomes of hybridisation (Wagner, 1969, 1983; Barrington et al. 1989; Haufler, 2002). In one case, the resulting tetraploid (resp. hexaploid, octoploid, etc.) offspring is a viable species that is reproductively incompatible with the parent taxa. It shows consistent morphological characters and can be assumed to be evolutionarily independent from its parent taxa. The triploid hybrids, on the other hand, are presumably sterile or nearly so and do not form independently generatively reproducing populations, even though they may possibly persist vegetatively for long times. I here refer to the first type of hybrids as "species of hybridogenic origin" or nothospecies sensu Wagner $(1969,1983)$, whereas the second type is simply called "hybrids". It should also be emphasized that the formation of orthospecies sensu Wagner $(1969,1983)$, i.e., speciation via gradual differentiation of allopatric populations, is an important speciation mechanism in Sticherus.

Unfortunately, comparative studies of these complex speciation and hybridisation processes among other populations of Sticherus in different geographical areas are lacking. However, my own field observations in Costa Rica and Bolivia, and the abundant herbarium material available from some well-collected locations, suggest that hybrid swarms commonly occur in Sticherus. This is supported by observations of specimens that are morphologically intermediate between other co-occurring species but lack distinctive characters of their own, and that show morphological irregularities, specially among the scales as described above for $S$. x pseudobifidus and $S$. x subremotus. I have therefore used the study by Jermy and Walker (1986) as a model of how to recognize possible hybridisation within the genus, and have interpreted such intermediate, irregularly malformed specimens as hybrids. In several cases, the separation of such putative hybrid specimens resulted in clearly defined parent taxa, that at a first glance appeared to grade into each other.

\section{Intrageneric relationships}

The only attempts at subdividing the genus Sticherus into infrageneric taxa was undertaken by Nakai (1950) who recognized four section based primarily on the plant architecture. Three of these section included only one species each. Section Caudipteris Nakai included S. simplex (Desv.) Nakai the only species in the genus with simple, undivided leaves. Sticherus retroflexus Copel. was placed in section 
Retroflexa Nakai characterized by short-creeping rhizomes and deflexed pinnules with somewhat decurrent bases. Section Nectopteris Nakai included Sticherus myriapoda Nakai which has a winding, climbing main axis. All other species were placed in section Holopterygium (Diels) Nakai. For practical purposes, this classification is of little use, since it merely picks out three distinctive species with unique characters, leaving the bulk of the genus in one large, unresolved section. Scale characters further suggest that both $S$. simplex and $S$. retroflexus are closely related to other species placed by Nakai in section Holopterygium. The classification of Nakai therefore does not reflect natural relationships.

I here refrain from formally defining infrageneric taxa such as sections or subgenera within Sticherus, because there are no apparent, clearly defined groups. While some species clearly are closely related to each other and form species-groups, these groups are almost always linked by intermediate species, and numerous species do not show any obvious relationships to others. This situation is further complicated by the apparently high incidence of hybridisation within the genus, which apparently is not limited to closely related species. Molecular studies will be needed to clarify the relationships between the species.

Based primarily on scale characters, the following 12 informal species groups can be established. These are useful for identification purposes and the key to the species provided here essentially follows these characters. These groups may also partly correspond to natural entities. It should be emphasized, however, that within each of these groups there is considerable variation in other characters, e.g., the branching pattern or the presence/absence of squamophores, and future studies may show these characters to indicate true relationships more faithfully than the scale characters used here. This order also corresponds to the order of the species in the treatment.

A. Group of S. bifidus: midvein scales hyaline, lax to semi-rigid, triangular; abaxial segments with arachnoid scales; plants usually slender. S. bifidus, S. chocoensis, $S$. cubensis, $S$. decurrens, $S$. ferrugineus, $S$. interjectus, $S$. nigropaleaceus, $S . x$ pseudobifidus, and $S$. x subremotus. 
B. Group of S. fulvus: midvein scales hyaline, lax to semi-rigid, triangular; abaxial segments with arachnoid scales, whitish to dark orange, proximal internal segments semicircular to winglike, S. aurantiacus, S. fulvus, S. fuscus, and S. tepuiensis.

C. Grupo of S. maritimus: densely scaly, the scales grated hyaline, whitish to dark orange, last axis linear: S. arachnoideus, S. rufus, and S. maritimus

D. Group of S. tomentosus: midvein scales grated, stoutly hyaline, long-lanceolate to linear; abaxial segments with or without arachnoid scales; plants usually robust., $S$. blepharolepis, S. hispaniolensis, S. lanosus, and S. tomentosus. S. jacha is intermediate between groups $\mathrm{D}$ and $\mathrm{F}$.

E. Group of S. lanuginosus: midvein scales fimbriate; abaxial segments with or without reduced fimbriate scales. S. lanuginosus, $S$. squamosus, and $S$. velatus.

F. Group of S. melanoblastus: scales hardening from the base; midvein scales lanceolate; veinlets strongly raised; abaxial segment surface with scattered, coarsely star-shaped scales or glabrous. S. melanoblastus, S. peruvianus, and S. remotus.

G. Group of S. rubiginosus: scales hardening from the margins; midvein scales linear-lanceolate; veinlets weakly raised; abaxial segments surface with fimbriate scales or glabrous or papillate. S. brittonii, S. farinosus, S. strictissimus, and $S$. rubiginosus.

H. Group of S. revolutus: midvein scales stoutly hyaline, linear; abaxial segments with scattered fimbriate scales or glabrous. S. lechleri, S. pruinosus, and S. revolutus. S. boliviensis is intermediate between groups $\mathrm{E}$ and $\mathrm{H}, \mathrm{S}$. nervatus is intermediate between groups $\mathrm{F}$ and $\mathrm{H}, \mathrm{S}$. jamaicensis is intermediate between groups $\mathrm{K}$ and $\mathrm{E}$, and S. underwoodianus is intermediate between groups D and E.

I. Group of $S$. furcatus: midvein scales hyaline, star-shaped. S. compactus and $S$. furcatus. 
J. Group of S. pallescens: bud and midvein scales opaque, whitish; scales of different plant parts only differing in size; abaxial segments glabrous. S. albus and $S$. pallescens.

K. Group of S. nudus: bud scales grated, hyaline, ovate; midvein scales ovate; abaxial segments with fimbriate scales or glabrous. S. nudus, S. ovatus, and S. pteridellus. S. brevitomentosus is intermediate between groups $\mathrm{B}$ and $\mathrm{F}$.

L. Group of S. hypoleucus: bud scales spreading, narrowly lanceolate, stoutly hyaline with setose margins; abaxial segment surface usually glabrous. S. gnioides, $S$. gracilis, and S. hypoleucus.

M. Group of S. retroflexus: only with bud and rhizome scales, otherwise glabrous; axes flexuous; segments hastulate; pinnae with basal accessory segments. $S$. hastulatus, S. intermedius, S. orthocladus, and S. retroflexus.

N. S. longipinnatus: close to group I, but with anchor-shaped, stoutly hyaline midvein scales.

\section{Systematic treatment}

Sticherus C. Presl, Tent. Pterid. 51. 1836. Lectotype. Sticherus laevigatus (Willd.) C. Presl - designated by Christensen, Index Fil. 54. 1906.

Mertensia Willd., Kongl. Vet. Acad. Nya Handl. 167. 1804. nom. ileg., non Mertensia Roth (1797). Lectotype. Mertensia dichotoma (Thunb.) Willd. designated by Bernhardi, Neues J. Bot. 1: 38. 1805.

Gleichenia subgen. Mertensia Hook., Sp. Fil. 1: 4. 1844. non Mertensia Willd. (1804), nec Roth (1797). Type: Gleichenia truncata (Willd.) Spreng. (三Mertensia truncata Willd.). 
Gleichenia (subgen. Mertensia) sect. Holopterygium Diels, Nat. Pflanzenfam. 1: 353. 1900. - Dicranopteris sect. Holopterygium (Diels) Underw., Bull Torrey Bot. Club 34: 251. 1907. Type. Gleichenia pubescens (Humb. \& Bonpl. ex Willd.) Kunth in H.B.K. (三 Mertensia pubescens Humb. \& Bonpl. ex Willd.).

Plants slender to robust. Rhizomes protostelic, 1-10 mm thick, burried near the soil surface, dark brown to reddish, brittle to rugose, sometimes with squamophores that persist when the scales fall off, deciduously to densely scaly, the scales usually denser at bifurcations and near petiole bases, 1-6 mm long, ovate to narrowly lanceolate, the margins usually setose, cell texture usually rigid to semiclathrate with well differentiated cells, orange, golden-orange to reddish-brown. Petioles 1-8 mm thick and ca. $15-50 \mathrm{~cm}$ long, castaneous to stramineous, lustrous to rugose, usually supaleaceous with scattered scales resembling the rhizome scales but more hyaline. Rachises 5-45 cm long between pinnae, usually paleaceous with longer bud scales, aphlebiae absent, simple, or trimerous to pinnatifid. Fiddleheads $2-10 \mathrm{~mm}$ in diameter, glabrous to densely scaly, usually matted whitish to orange or speckled with dark brown rows. Buds appressed or opening rapidly, scales 1-8 mm long, ovate to narrowly lanceolate, rounded to truncate bases, with fringed, pilose, or glandular apices, the margins cliate to setose, whitish to dark orange or bicolorous, cell texture hyaline, rigid, or mixed, cell shape rounded, hexagonal, or linear. Pinnae $15-70 \mathrm{~cm}$ long, axes adaxially flat or protruding, simple or usually 1- to 6-forked, often unequally, $1^{\text {st }}$ axes linear to lanceolate, pectinate or not, distal axes pectinate, pinnatifid, pinnatisect, or remote, usually with 2-3 segments per cm; adaxially glabrous to densely scaly, the scales linear, hair-like, star-shaped, or of rectangular outline, usually lax-hyaline, whitish to orange, laterally abaxially scatteredly to densely scaly, the scales ovate to narrowly lanceolate, usually shorter and more hyaline than the bud scales, 1-6 mm long, cell texture hyaline to mixed, the margins usually ciliate with few to abundant, straight or tortuosus cilia $1 / 20-1 \times$ the scale length. Segments 3-50 x 4-5 mm, linear to oblong, usually chartaceous, usually margins narrowly revolute or flat; adaxially usually glabrous, when scaly, the scales deciduous, similar to the scales of the midvein and abaxial segment surfaces; abaxially glabrous, papillate, and/or scatteredly to densely scaly, usually with arachnoid scales or simple trichomes; veinlets 1-forked, thin or thick, diverging to parallel, castaneous or blackish, obscure to raised, midvein usually thick, raised, 
whitish to orange, with differentiated scales on the surface, scales in Y-shaped, linear, filiform, square, rhomboid, star-shaped, or lanceolate, usually long ciliate, cell texture lax-hyaline, semirigid to mixed, whitish, dark orange or bicolorous. Sori inframedial or medial, nested within arachnoid scales or unnested, 3-35 pairs per segment, (2)3-4(7) globose sporangia per sorus, paraphyses absent. Spores monolete, ellipsoidal, surface rugulate, usually perforate; $x=34$.

\section{Key to the Neotropical species of Sticherus and some of the interspecific hybrids}

1. Pinnae simple, pectinate-pinnatisect 39. S. simplex

1. Pinnae 1- to 5-forked.

2. Segments rounded, oval or triangular, less than $1 \mathrm{~cm}$ long.

3. Abaxial segment surface glabrous or papillose.

4. Bud scales ciliate. 48. S. gracilis

4. Bud scales entire.

5. Segments less than $3 \mathrm{~mm}$ long, pinnatisect 49. S. gnidioides

5. Segments more than $5 \mathrm{~mm}$ long, pinnatifid 47. S. hypoleucus

3. Abaxial surface of segments scaly.

6. Abaxial segment surface densely scaly with dark orange, arachnoid scales.... 12. S. maritimus

6. Abaxial segments surface glabrous or only midvein with scales.

7. Bud and abaxial axis scales concolous, entirely hyaline.

9. Bud and abaxial axis scales stoutly hyaline with rigid margins; midvein scales with whitish Yshaped hair-like scales.... 30. S. strictissimus

9. Bud and abaxial axis scales stoutly hyaline to bicolorous with dark centers and hyaline margins; midvein scales linear to contorte. 41. S. boliviensis

7. Bud and abaxial axis scales bicolorous, with hardened parts.

10. Rachis and proximal axis with pinnatifid aphlebiae; only the last two axes segmented; axes adaxially with segmented hair-like scales; rhizome with squamophores. 34. S. revolutus

10. Rachis and proximal axis lacking aphlebiae; all axes segmented, or only the $1^{\text {st }}$ proximal axis not segmented; axes adaxially glabrous or with long linear scales; rhizome lacking scquamophores.

$11.1^{\text {st }}$ axis longer than the $2^{\text {nd }}$; veinlets raised; abaxial axes densely scaly, the scales usually covering whole segment; scales broadly lanceolate, basally cordate. 
11. $1^{\text {st }}$ axis shorter than the $2^{\text {nd }}$; veinlets obscure; abaxial axes moderate scaly to glabrous; scales narrowly lanceolate, basally truncat.... 36. S. pruinosus

2. Segments oblong or linear or basally conspicuously hastulate, more than $1 \mathrm{~cm}$ long.

12. Abaxial segment surface densely scaly with arachnoid scales.

13. Last axes with reduced, winglike internal proximal segments.

14. Bud scales bicolorous with stoutly hyaline to rigid centers and hyaline margins, ciliate; midvein scales linear, lax-hyaline.

11. S. aurantiacus

14. Bud scales completely dark or bicolorous with hyaline bases and rigid apices, usually setose; midvein scales star-shaped to linear, with mixed cell texture.

15. Proximal axes arched; midvein scales appressed, grated-hyaline; fiddleheads loosely scaly, greenish. 10. S. tepuiensis

15. Proximal axes straight; midvein scales matted, lay-hyaline; fiddleheads densely scaly, whitish to orange 8. S. fulvus

13. Last axes with internal segments lacking or gradually reduced.

16. Aphlebiae lacking; last axes lacking proximal internal segments, lanceolate, basally equally or unequally truncate.

17. Last axis pinnatifid; veinlets slightly raised; bud scales lanceolate, acuminate, margins with delicate and numerous cilia. 1. S. bifidus

17. Last axis pinnatisect; veinlets raised; bud scales rounded, entire or irregularly cilate.

18. Bud scales bicolorous with dark centers and hyaline margins, lanceolate, basaly cordate; midvein scales apressed, short-lancelate to linear, hyaline; rhizome scales lanceolate, rigid 45. S. brevitomentosus

18. Bud scales concolorous, grated-hyaline, rounded, glandular; midvein scales imbricate, rounded scales; rhizome scales ovate, hyaline 44. S. ovatus

16. Aphlebiae trimerous to simple; last axes with proximal segmets gradually reduced, lanceolate or linear.

19. Bud scales completely dark or bicolorous with dark apices or scatterd dark patches, margins setose and/or ciliate.

20. Abaxial axis scales completely dark or bicolorous with hyaline bases and dark apices; abaxial segment surface scales dark orange; segments oblong, to $2 \mathrm{~cm}$ long... 
20. Abaxial axis scales hyaline scales or occasionally with rigid apices; abaxial segment surface scales whitish to pale orange; segments linear, to $3 \mathrm{~cm}$ long.

21. Aphlebiae slightly pinnatifid; Bolivia and Brazil 2. S. decurrens

21. Aphlebiae narrow, trimerous; Caribbean and northern South America.

22. $1^{\text {st }}$ axis to $4 \mathrm{~cm}$ long, opposite pairs of axes roughly equal in length; all axes pinnatifid..... 4. S. cubensis

22. $1^{\text {st }}$ axis over $5 \mathrm{~cm}$ long, opposite pairs of axes strongly unequal in length; proximal axes remotely pectinate and distally pinnatifid 54. S. x pseudobifidus

19. Bud scales concolorous, soutly hyaline or bicolorous with dark bases, margins with delicate or short, thick cilia.

23. All scales dark orange to cinnamon; midvein scales lanceolate or star-shaped, cell texture hyaline to stoutly hyaline.

24. Pinnae more than 3-forked; all axes pectinnate, linear; segments oblong, to $2 \mathrm{~cm}$ long, equally arranged 13. S. rufus

24. Pinnae to 3-forked; only last axis full ectinate, lanceolate; segments linear, over $2.5 \mathrm{~cm}$ long.

25. Segments linear, to $2 \mathrm{~mm}$ wide; midvein cales star-shaped; aphlebiae narrow, trimerous; fiddleheads matted with appresed scales.

25. Segments oblong, over $3 \mathrm{~mm}$ wide; midvein ... scales lanceolate; aphlebiae pinnatifid to trimerous; fiddleheads densely scaly with erect, spreadig scales

15. S. tomentosus

23. All scales whitish to pale orange; midvein scales rectangular to linear, cell texture lax hyaline.

26. Midvein scales linear, contorted to filamentous, margins erose; abaxial axis and bud scales fimbriate. 20. S. velatus

26. Midvein scales rectangular or triangular to irregularly shaped, margins long cliate; abaxial axis and bud scales lanceolate with delicate to thick cilia.

27. Segments linear; bud scales narrowly lanceolate, grated-hyaline, sometimes basally semirigid but not dark in color 3. S. ferrugineus

27. Segments oblong; bud sclaes lanceolate, stoutly hyaline, basally darker. 
28. Pinnae to 3-forked; only last axis fully pectinate, linear; segments to $2 \mathrm{~cm}$ long, segments within a pinna of roughly equal size; bud scales with abundant, delicate cilia 14. S. arachnoideus

28. Pinnae more than 3-forked; proximal axes internally pectinate, last axis lanceolate, usually narrower than the proximal ones; segments unequal in length, 1-3 cm long; bud scales with short and delicate, or thick cilia.

29. Segments abaxially densely scaly; bud scales stoutly hyaline with dark, but not rigid margins, margins with short, delicate cilia; Greater Antilles 17. S. hispaniolensis

29. Segmets abaxially moderately scaly; bud scales stoutly hyaline to basally hardened, margins with thick cilia. Central Andes and southeastern Brazil 16. S. lanosus

12. Abaxial surface segments glabrous or only midvein scaly.

30. Segments abaxially completely glabrous.

31. Bud scales lanceolate, ciliate; segments ovate, basally adnate.

32. Pinnae robust, axes over $2 \mathrm{~mm}$ thick; segments linear, over $2.5 \mathrm{~cm}$ long; proximal axes abaxially densely scaly, last axes and segments glabrous. 26. S. pallescens

32. Pinnae slender, axes to $2 \mathrm{~mm}$ thick; segments oblong, to $2.5 \mathrm{~cm}$ long; proximal axes abaxially glabrous or scatteredly scaly.

33. Proximal axes not pectinate; aphlebia broad; only last two distal axes scaly; rhizome with squamophores; Central Andes 40. S. lechleri

33. Proximal axes internally pectinate; aphlebiae narrow; all axes pectinate; rhizome lacking squamophores; West Indies... 38. S. jamaicensis

31. Bud scales ovate, entire; segments linear to triangular, basally hastulate, shortly petiolate or adnate

34. Petioles over $3 \mathrm{~mm}$ thick; all axes segmented; proximal axes with auriculate segments; distal axes with adnate segments. 53. S. intermedius

34. Petioles to $2 \mathrm{~mm}$ thick.

$35.1^{\text {st }}$ axes segmentes, segments adnate; axis to $130^{\circ}$ apart, slightly flexuose; rhizomes rugose.

$35.1^{\text {st }}$ axes not segmeted; segments semiadnate to auriculate; axes over $130^{\circ}$ apart, slightly to strongly flexuose; rhizome lustrous

36. Axes strongly flexuose; segment bases emiadnate, basiscopically auriculate; segments 2-3 cm long. 50. S. retroflexus 
36. Axes slightly flexuose; segment bases shortly petiolate, auriculate; segments $0.4-2.5 \mathrm{~cm}$ long 52. S. hastulatus

30. Segments abaxially with midvein scales and/or veinlet scales and/or papillose.

37. All scales dark brown-cinnamon in color, spreading, subulate, short-ciliate, subclathrate; midvein scales anchor-shaped with a long apical and two lateral cilia; pinnae 2-forked; $1^{\text {st }}$ axis very short, $2^{\text {nd }}$ axis long, widely lanceolate. 42. S. longipinnatus

37. Scales whitish to blackish, usually appressed, lanceolate to ovate, when subulate then bicolorous, entire or ciliate; midvein scales not anchor-shaped; pinnae 2- to more-forked.

38. Abaxial axis scales scattered; all scales ovate, entire or short-ciliate, hyaline; aphlebiae lacking.

$39.1^{\text {st }}$ axis arching, usually the longer than the $2^{\text {nd }}$; segments oblong, $1.5-3 \mathrm{~cm}$ long, 2-3.5 mm wide; rhizome scales lanceolate, rigid 43. S. nudus

39. $1^{\text {st }}$ axis straight, similar in length to the $2^{\text {nd }}$; segments linear, obtuse, $1.5-2 \mathrm{~cm}$ long, 2-2.5 $\mathrm{mm}$ wide; rhizome scales ovate, hyaline 46. S. pteridellus

38. Abaxial axis scales scattered to dense; all scales lanceolate, ciliate or setose, hyaline to bicolorous; aphlebiae present or lacking.

40. Axes remotely pinnatisect; segments linear; aphlebiae long, narrowly trimerous to pinnatifid; veinlets obscure; abaxially axis scales scattered; apically darkened.

41. All axes remotely pinnatisect; bud scales rigid, completely dark, setose. 31. S. remotus

41. Only proximal axes remotely pinnatisect; bud scales mixed, hyaline with rigid parts.

42. $1^{\text {st }}$ axes shorter than the $2^{\text {nd }}$, opposite axes of similar length; bud scales narrowly lanceolate, setose, rigid; southeastern Brazil and Bolivia.

42. $1^{\text {st }}$ axes longer or shorter than the $2^{\text {nd }}$, 7. S. nigropaleaceus opposite axes of unequal length; bud scales lanceolate, ciliate, rigid with hyaline margins; northern South America.

43. Bud scales lanceolate-subulate with a long apical hair; midvein scales star-shaped, hyaline 6. S. interjectus

43. Bud scales lanceolate; midvein scales laxely star-shaped, lax-hyaline. 55. S. x subremotus

40. Axes pinnatisect to pinnatifid; segments linear to oblong; aphlebiae lacking, simple, or widely pinnatifid; veinlets raised or obscure;abaxial axis scales hyaline or centrally darkened. 
44. Aphlebiae lacking; axes remotely pinnatisect separated by a narrow membrane, lacking maximal internal segments; last axes truncatelanceolate; abaxial axis scales scattered, semirigid, dark; bud scales dark. 32. S. melanoblastus

44. Aphlebiae present; axes remotely pinnatisect to pinnatifid, proximal internal segments gradually reduced; abaxial axis scales scattered to dense, hyaline to rigid; bud scales bicolorous.

45. Abaxial axes protruding, scatteredly scaly; midvein scales star-shaped.

46. Axes remotely pinnatisect; abaxial axis scales margins rigid with thin setae.

47. Veinlets thick, raised; midvein scales thick, whitish, scattered, Y-shaped to linear.

47. Veinlets slender, not raised; midvein scales star-shaped, proximally with some rigid cilia, distally hyaline

23. S. compactus

46. Axes pinnatisect; abaxial axis scales, margins hyaline, short-ciliate.

48. Axes ca. $1 \mathrm{~mm}$ thick; aphlebiae to $0.5 \mathrm{~cm}$ long; segment margins ciliate; midvein and veinlet scales whitish

24. S. furcatus

48. Axes ca. $2 \mathrm{~mm}$ thick; aphlebiae ca. $1 \mathrm{~cm}$ long; segment margins glabrous; midvein scales dark orange, veinlets glabrous 56. S. x leonis

45. Abaxial axes not protruding, densely scaly; midvein scales lanceolate, linear, or filamentous.

49. Pinnae more than 4-forked; bud and abaxial axis scales fimbriate; midvein and veinlet scales filamentous, contorted.

50. Proximal axes thick, very short, spreading at angles to $45^{\circ}$; midvein scales hyaline, whitish; segments $0.5-2 \mathrm{~cm}$ long; ca. 3 segments per $\mathrm{cm}$ 22. S. lanuginosus

50. Proximal axes slender, unequal in size, spreading at ca. $90^{\circ}$; midvein scales stoutly hyaline, dark orange to cinnamon; segments 1-3 cm long; ca. 2 segments per $\mathrm{cm}$ 21. S. squamosus

49. Pinnae to 3-forked; bud scales ciliate; midvein scales linear to lanceolate.

51. $1^{\text {st }}$ axes ca. $2 \mathrm{~mm}$ thick; abaxial axis scales whitish to bicolorous; veinlets thin, parallel; midvein scales lanceolate to rectangular.

52. Only proximal abaxial axes scaly; abaxial segment surface usually glabrous, or with scattered square, short, hyaline, brown scales 
52. All abaxial axes scaly; abaxial segment surface scaly, the scales lancelate to square.

53. Midvein scales lanceolate, hyaline, whitish; veinlets glabrous; axes pectinate, with 2-3 segments per cm; sori lacking scales. Caribbean region 25. S. albus

53. Midvein scales square, apically fringed, bicolorous to whitish; veinlets glabrous or with scattered filaments or linear, contorted scales; axes remotely pinnatisect to pinnafid, with 1.5-2 segments per $\mathrm{cm}$; sori nested in scales; Central Andes.

54. Axes remotely pinnatisect; segmets channelled; veinlets with scattered filaments or linear, contorted scales; abaxial axis scales usually bicolorous, basally brown, rigid, margins whitish with irregularly arranged cilia 19. S. jacha

54. Axes pinnatifid; segmets flat; veinlets glabrous; abaxial axis scales whitish, hyaline, margins with delicate cilia 18. S. blepharolepis

51. $1^{\text {st }}$ axes ca. $1 \mathrm{~mm}$ thick; abaxial axis scales brown; veinlets obscure or thick and raised; midvein scales lanceolate to linear.

55. Abaxial axis scales lanceolate, basally rounded; midvein scales lanceolate; proximal axes slightly arched, not pectinate 33. S. peruvianus

55. Abaxial axis scales narrowly lanceolate, basally truncate; midveins linear to contorted; proximal axes straight, pinnatifid to pinnatisect.

56. Veinlets thick, abaxially raised; bud scales rigid to stoutly hyaline, dark brown to dusty orange; abaxial axis scales stoutly hyaline with usually rigid margins.

57. Veinlets with simple, whitish hair-like scales; abaxial segment surface densely papillose; West Indies 29. S. farinosus

57. Veinlets with hair-like, contorted to linear, orange scales; abaxial segment surface smooth; Central and South America 27. S. rubiginosus

56. Veinlets obscure or slightly raised; bud scales hyaline, brilliant orange to dark orange. 
58. Aphlebiae widely pinnatifid to trifoliate; only last two distal axes pectinate; abaxial axis and bud scales lanceolate with a long, usually segmented apical hair; rhizome with squamophores.

59. Axes pinnatisect; segment margins revolute; midveins densely scaly; abaxial axes densely scaly; adaxial axes with segmented, hair-like scales. 34. S. revolutus

59. Axes pinnatifid; segment margins flat; midveins glabrous; abaxial axes scatteredly scaly to glabrous; adaxial axes with linear scales 40. S. lechleri

58. Aphlebiae narrowly pinnatifid; abaxial axis and bud scales lanceolate, apically fringed; all axes pectinate, proximal ones only with internal segments; rhizome lacking squamophores.

60. Midveins proximally densely scaly; axes with ca. 2.5 segments per $\mathrm{cm}$ 37. S. underwoodianus

60. Midveins glabrous, occasionally with scattered scales; axes with ca. 3 segmets per $\mathrm{cm}$ 38. S. jamaicensis

1. Sticherus bifidus (Willd.) Ching, Sunyatsenia 5: 282. 1940.

Mertensia bifida Willd., Kongl. Vetensk. Acad. Nya Handl. 25: 168. 1804. Gleichenia bifida (Willd.) Spreng., Syst. Veg. 4: 27. 1827. Dicranopteris bifida (Willd.) Maxon, N. Amer. Fl. 16: 60. 1909. Type. Venezuela, Distrito Federal, Caracas, Bredemeyer s.n. (holotype, B, Willd. 19468).

Mertensia pubescens Humb. \& Bonpl. ex Willd., Sp. Pl. ed 4,5: 73. 1810. Gleichenia pubescens (Humb. \& Bonpl. ex Willd.) Kunth in H.B.K., Nov. Gen. Sp. Pl. 1: 29. 1816. Dicranopteris pubescens (Humb. \& Bonpl. ex Willd.) Conz., Fl. Taxon. Mexic. 1: 129. 1939. Sticherus pubescens (Humb. \& Bonpl. ex Willd.) Nakai, Bull. Natl. Sci. Mus. 29: 25. 1950. Type. Venezuela, Sucre, Cunamá, Santa Cruz, Humboldt \& Bonpland s.n. (holotype, B -Willd. 19467).

Plants medium-sized, slender. Rhizome 1.5-2.5(3) mm thick, dark brown to reddish brown, the scales deciduous, concentrated at bifurcations and at petiole bases, linear- 
lanceolate, long-acuminate with 2 apical setae, $1-3 \times 0.2-0.6 \mathrm{~mm}$, the margins with short, thin setae, cell texture rigid, usually with hyaline bases dark brown. Petiole ca. 20-70 cm long and 1.6-4.5 mm thick, light-castaneous, stramineus, basally with scattered scales resembling those of the rhizome. Rachis $15-25 \mathrm{~cm}$ long between pinnae, subpaleaceus, aphlebiae absent. Fiddlehead (2.5)3-8 mm in diameter, densely scaly, the scales appressed, matted, whitish to pale orange. Bud small, appressed, the scales lanceolate with rounded bases, apically glandular or with short cilia, 1.5-4.6 x 0.4-0.6 mm, basally $15-25$ cell rows wide, whitish to light orange, the margins with numerous, delicate, contorted cilia 1/7-1/4 x the scale length, cell texture grated, lax-hyaline, with rounded cells. Pinnae (25)35-50(70) cm long, 1- to 3 -forked (often unequally), $1^{\text {st }}$ (and sometimes $2^{\text {nd }}$ ) axis linear to narrowly lanceolate, shorter than the $2^{\text {nd }}, 2.5-4(8) \mathrm{cm}$ long and 1-2 mm thick, usually not pectinate or with scattered internal segments, last axis 10-30(50) cm long and ca. $1 \mathrm{~mm}$ thick, pectinate-pinnatifid, 2-4(5) $\mathrm{cm}$ wide with segments, with 2-3 segments per $\mathrm{cm}$, the proximal internal segments lacking on the first $1-2 \mathrm{~cm}$, and the proximal external segments truncate; adaxially with mixed scales, one type triangular, 0.2-0.3 x 0.05$0.1 \mathrm{~mm}$, the second type linear, 1.4-2 x 0.3-0.5 mm, both scale types deciduous with age, whitish to light orange (specially on young pinnae), cell texture grated laxhyaline, the cells rectangular to irregular; abaxially the scales arranged laterally, lanceolate to ovate, $(0.6) 1.5-3 \times(0.2) 0.4-0.8 \mathrm{~mm}$, basally up to 7 cell rows wide, whitish, the margins with delicate cilia $1 / 5 \mathrm{x}$ the scale length, cell texture grated laxhyaline with rectangular cells. Segments 1.5-3(4) cm long and 1.8-2(3) mm wide, linear from a dilatate bases, apically pointed, chartaceous, the margins narrowly revolute; adaxially glabrous; abaxially densely scaly, the scales covering 70-100\%, arachnoid, 0.05-0.3 $\mathrm{mm}$ in diameter; veinlets thin, parallel, slightly raised; midvein scales triangular to rhomboid and occasionally linear, 0.2-0.4 x $0.1 \mathrm{~mm}$, whitish to light orange, the margins with abundant cilia $1 / 2-1 \times$ the scale length, cell texture grated lax-hyaline with irregular cells. Sori inframedial, nested within arachnoid scales, 15-38 pairs per segment, 3-4 sporangia per sorus.

Distribution and ecology. Widespread in mountains of Cuba, Trinidad and Tobago, Panama, Colombia, Venezuela, Guyana, Ecuador, Peru, Bolivia, and southeastern Brazil. Locally abundant in montane forests, clearings, and along roadsides, often 
forming large, pure colonies but also mixed within other shrubby vegetation, at 150$800 \mathrm{~m}$ on the Caribbean Islands and $325-2300 \mathrm{~m}$ in the Andes.

Sticherus bifidus is one of the most commonly misapplied names in the genus. It has been used for almost any specimen with a scaly indument on the abaxial segment surface in most herbaria, and by, e.g., Tryon \& Stolze (1989) and Moran (1995). Østergaard \& Øllgaard (2001) in their treatment of the genus Sticherus for Ecuador already noted that "S. bifidus" comprised several distinct species and described $S$. aurantiacus and $S$. brevitomentosus as new species. I here further treat S. ferrugineus, $S$. fulvus, $S$. decurrens, and $S$. ovatus as separate species. As a result, the present concept of $S$. bifidus is much narrower than that of previous workers and includes not only fewer collections but also only a single synonym (versus four synonyms cited by Østergaard \& Øllgaard (2001)). All these species form a group of closely related taxa that probably involves hybrid complexes. In fact, the variability of $S$. bifidus s. str. suggests that it may itself be of hybridogenic origin. This hypothesis needs to be corroborated by cytotanomic and/or molecular studies.

Sticherus bifidus is recognized by the combination of the following characters: the distal axes are linear to slightly lanceolate, aphlebiae are lacking, the proximal internal segments are lacking (the first segments are ca. 1-2 cm away from the bud), the indument is of a matted, whitish color, and the bud scales are glandtipped. Further diagnostic characters are the lax, grated, hyaline, ciliate bud scales which have more rounded basal cells than, e.g., S. ferrugineus. S. bifidus completely lacks hardened, darkened cells in any scale type. In comparison, S. fulvus has shorter, bicolorous scales with darkened cells and has short, but distinct internal proximal segments. S. ferrugineus has aphlebiae, often strongly orange scales, and linearlanceolata bud scales. S. decurrens has bud scales with darkened, twisted apices, and well-spaced segments on the $1^{\text {st }}$ axis.

Maxon $(1909,1912)$ described a monstrous form of $S$. bifidus, collected by himself (Jamaica, Below New Haven Gap, 1500-1600 m, Mar 1920, Maxon 936, US) on Jamaica. It is strikingly distinct in the highly reduced segments, resulting in 3-5 $\mathrm{mm}$ wide, subentire to broadly crenate wings along the axes, rather than the pinnatifid segments typical of $S$. bifidus. In all other characters, this collection is similar to $S$. bifidus. The monstrous specimens were found as a few plants amid a large population of S. bifidus. 
A different monstruous form is represented by several pinnatifid specimens from St. Vincent (Smith \& Smith 907, BM), Guadaloupe, (Herminier s.n., BM), and Trinidad (Tacarigua Ward, El Tucuche massif, 750 m, 7 Aug 1963, Jermy 2680, BM). They have pinnatifid segments, large pinnae that are up to $40 \mathrm{~cm}$ long and 10 cm wide, and slender, trimerous aphlebiae. These specimens may not belong to $S$. bifidus but rather to closely related species such as $S$. pseudobifidus, S. subremotus, and/or S. interjectus, but their identification is difficult because several important characters are hard to evaluate on such monstrous specimens.

2. Sticherus decurrens (Raddi) J. Gonzales, comb. nov.

Mertensia decurrens Raddi, P1. Bras. 1. 73 t. 1825. Type. Rio de Janeiro, Brazilia, Raddi s.n. (holotype, ?; isotype, P).

Gleichenia mathewsii Hook., Sp. Fil. 1: 9. t. 7B. 1844. Mertensia mathewsii (Hook.) Fée, Hist. Foug. Ant. (Mém. Foug. 11): 122. 1866. Sticherus mathewsii (Hook.) Nakai, Bull. Natl. Sci. Mus. 29: 22. 1950. Type. Perú, Mathews 1092 p.p. (holotype, K; isotype, US 01470309).

Mertensia trifurcans Fée, Crypt. Vasc. Br. 1.201 t. 74f. 1. 1869. Type, Brazil, Rio de Janeiro, Tijuca, Glaziou 1697 (holotype, K; isotype, US).

Plants small to medium-sized, slender. Rhizome 1.5-3.5 mm thick, dark brown, sparsely scaly, the scales narrowly lanceolate with two apical setae, (1.4)2.2-3.2 X 0.3-0.6 mm, reddish-brown, the margins with setae $1 / 11 \mathrm{x}$ the scale length, cell texture rigid with hexagonal cells. Petiole ca. 20-60 cm long and (1.5)3-4.5 mm thick, light-castaneous to stramineus. Rachis (12)20-85 cm long between pinnae, subpaleaceus, aphlebiae pinnatifid. Fiddlehead 3-6 mm in diameter, moderately scaly, the scales appressed, matted-whitish to speckled with brown rows. Bud small, appressed, the scales triangular-lanceolate, usually with long, twisted apices, (0.6)1$2(3.4) \times 0.2-0.4(0.6) \mathrm{mm}$, basally usually less than 15 cell rows wide, opaque whitish to speckled with brown apices, the margins with delicate cilia 1/5-1/7 $\mathrm{x}$ the scale length, cell texture hyaline, usually rigid at the apices, the cells rounded to rectangular. Pinnae 25-60 cm long, 2- to 3-forked, $1^{\text {st }}$ axis ca. (2)4-6.5(10) cm long 
and $1.5-2.5 \mathrm{~mm}$ thick, only with internal segments adjacent to the aphlebiae, $2^{\text {nd }}$ axis usually shorter than the $1^{\text {st }}$, opposite pairs of unequal length, ca. 4-10 cm long, when distal ca. $40 \mathrm{~cm}$ long, pectinate, $3-7 \mathrm{~cm}$ wide, segments basally gradually reduced, overlapping, $3^{\text {rd }}$ and last axis ca. 20-40 cm long, lanceolate, $3-5 \mathrm{~cm}$ wide with segments, with ca. 2 segments per $\mathrm{cm}$; scales adaxially mixed, one type triangular to irregularly shaped, 0.2-0.3 x 0.05-0.1 mm, the second type linear, 1.4-2 x 0.3-0.5 $\mathrm{mm}$, both scale types whitish to light orange (specially on young pinnae), deciduous with age, cell texture grated, lax-hyaline; abaxially scaly, the scales laterally arranged, triangular with long, twisted apices, $(0.3) 1.2-2.5 \times 0.2-0.6 \mathrm{~mm}$, the margins basally with cilia $1 / 3$ and apically with setae $1 / 5 \mathrm{x}$ the scale length, cell texture hyaline with hardened cells usually restricted to the apices. Segments linear from a dilatate base, apices pointed, herbaceous to thin chartaceous, 2-4 cm long and 2-3 $\mathrm{mm}$ wide, the margins narrowly revolute; adaxially glabrous; abaxially scaly, the scales covering (15)20-50\% of the segments surface, arachnoid, 0.05-0.3 $\mathrm{mm}$ in diameter; veinlets thin, parallel, slightly raised; midvein scales mixed, one type hairlike, 1-2 $\times 0.05-0.2 \mathrm{~mm}$, the margins with cilia $1 \times$ the scale length, the second type triangular to rhomboid, usually long-aristate, 0.2-0.4 x 0.1-0.2 mm, the margins with cilia $1 \mathrm{x}$ the scale length, both scale types whitish, with grated lax-hyaline cell texture. Sori inframedial, located on the distal half of the segment, slightly nested within arachnoid scales, ca. 8-27 pairs per segment, 3-4(6) sporangia per sorus.

Distribution and ecology. Andes of Venezuela, Colombia, Ecuador, Peru, and Bolivia, Guyana, southeastern Brazil. Very common in Brazil and somewhat less so in Bolivia, but quite rare elsewhere in its range. Grows mainly in open, disturbed habitats such as on landslides and along roadcuts, but is also found in secondary and disturbed forests. $300-2750 \mathrm{~m}$ in the Andes, $1000 \mathrm{~m}$ in Guyana, and 120-1500 $\mathrm{m}$ in Brazil.

This species is closely related to $S$. bifidus and S. ferrugineus, and has long been merged with S. bifidus, e.g., by Tryon \& Stolze (1989) and Østergaard \& Øllgaard (2001). However, S. decurrens can be recognized by its pattern of cell hardening on the bud and abaxial axis scales. Whereas $S$. bifidus lacks hardened cells at all and in S. ferrugineus the hardening starts at the scale base, in S.decurrens the hardening starts at the scale apices. The hardened scale apices on S. decurrens are 
twisted in a very characteristic way that is not found in any other species of Sticherus. A further character of $S$. decurrens is the mixture of arachnoid scales (as found in S. bifidus) and fibrillose scales (as found in S. lanuginosus and allies) on the abaxial segment surface. With respect to the aphlebiae, $S$. decurrens is intermediate between S. bifidus (which lacks them) and S. ferrugineous (which has welldeveloped aphlebiae), having short, vestigious aphlebiae. Overall, S. decurrens is a fairly short species with short pinnae with somewhat lanceolate distal axes.

As defined here, $S$. decurrens is a rather variable species. While many specimens are typical for the species, other collections may be hybrids with $S$. bifidus, S. ferrugineus, S. nigropaleaceus, and possibly others. The problem in distinguishing "true" $S$. decurrens from such hybrids is that the characters defining $S$. decurrens are intermediate between those of the species cited above. It is conceivable that $S$. decurrens is of hybridogenic origin, but there is no doubt that today it is a distinct, viable species. The variability of this species and the similarity of the putative hybrids has prompted the description of several species that I consider to be synonymous to $S$. decurrens ( $S$. mathewsii, $S$. trifurcans and possibly also $S$. immersus, see under doubtful names). Some of these names may actually apply to hybrids rather than to $S$. decurrens. Cytological and molecular studies are needed to clarify these problems.

3. Sticherus ferrugineus (Desv.) J. Gonzales, comb. nov.

Mertensia ferruginea Desv., Ges. Naturf. Berlin Mag. Neusten Entdeck. Gesamten Naturk. 5: 307. 1811 Type. French Guiana, collector unknown (holotype, P, hb. A.N. Desvaux).

Plants medium-sized, slender to semi-robust. Rhizome 1.8-2.5(3) mm thick, dark brown, deciduously scaly, the scales narrowly lanceolate, acuminate with 1-2 apical setae, (0.8)2.5-3.5 x (0.2)0.4-0.8 mm, dark-brown to reddish, the margins irregularly setose, cell texture rigid with square to hexagonal cells. Petiole $30-80 \mathrm{~cm}$ long and 1.8-2.5(4.5) $\mathrm{mm}$ thick, rough, light castaneous. Rachis 10-35 cm long between pinnae, aphlebiae simple to pinnatifid at the basis. Fiddlehead $1.5-3 \mathrm{~mm}$ in diameter, densely scaly, the scales appressed, matted, orange. Bud small, semi-appressed, the scales lanceolate to narrowly lanceolate, basally truncate, $(0.3) 1.5-3(5) \times(0.2) 0.4-$ 
$0.8(1.3) \mathrm{mm}$, basally ca. 15 cell rows wide, orange to bicolorous with dark bases, the margins with numerous delicate, undulate cilia 1/3-1/5(1/8) $\mathrm{x}$ the scale length, cell texture grated hyaline, usually basally rigid, with square to linear cells. Pinnae 30$50(70) \mathrm{cm}$ long, 2- to 3-forked, $1^{\text {st }}$ axis shorter than the others, $1.5-10 \mathrm{~cm}$ long and $1.5-3 \mathrm{~mm}$ thick, only with proximal, internal segments adjacent to the aphlebiae, $2^{\text {nd }}$ (sometimes distal) axis 4-8(40) $\mathrm{cm}$ long and $1 \mathrm{~mm}$ thick, 4-7 $\mathrm{cm}$ wide with segments, opposite axes of unequal length, $3^{\text {rd }}$ and usually distal axis $12-40 \mathrm{~cm}$ long and $1 \mathrm{~mm}$ thick, pectinate-pinnatifid, $4-5 \mathrm{~cm}$ wide with segments, with 2-2.5 segments per $\mathrm{cm}$; adaxially with mixed, deciduous scales, one type triangular to arachnoid, 0.05-0.4 x 0.01-0.1 mm, with numerous, delicate and contorted cilia $1 \mathrm{x}$ the scale length, the second type linear, 1-1.8 x 0.1 mm, basally hair-like, apically wider with numerous delicate cilia 1/3-1/2 x the scale length, both scale types lax-hyaline, whitish to light orange (specially on young pinnae); abaxially with laterally arranged, often imbricate scales, the scales lanceolate to linear lanceolate, basally truncate, apically fringed or glandular, (0.5)1.6-2.6 x (0.1) 0.2-0.7 mm, basally ca. 10 rows wide, whitish to orange, the margins with numerous, delicate, and contorted cilia 1/2-1 x the scale length, cell texture grated-hyaline with rectangular cells. Segments (0.6)1.3-2.5(3.6) x 0.2-0.3 mm, linear from a dilatate base, apices rounded, semi-chartaceous, the margins narrowly revolute; adaxially glabrous; abaxially moderately to densely scaly, the scales covering $25-70 \%$ of the leaf surface, arachnoid $0.05-0.3 \mathrm{~mm}$ in diameter; veinlets thin, parallel, slightly raised; midvein scales triangular to rhomboid, (0.3)0.6-1.4(2) x 0.05-0.1(0.2) mm, ca. 3-5 cells wide, the margins with long, contorted cilia 2-3 x the scale length, cell texture lax-hyaline; abaxially with arachnoid scales; adaxially glabrous. Sori inframedial, superficially nested within arachnoid scales, 12-28 pairs per segment, 3-5 sporangia per sorus.

Distribution and ecology. Widespread in mountains of the West Indies, Central America, and South America: Mexico, Guatemala, Honduras, El Salvador, Nicaragua, Costa Rica, Panama, Jamaica, Haiti, Dominican Republic, Puerto Rico, St. Kitts, Montserrat, Guadeloupe, Dominica, St. Lucia, St. Vincent, Martinique, Grenada, Trinidad and Tobago, Colombia, Venezuela, Ecuador, Peru, Bolivia, and southeastern Brazil. Common in northern Mesoamerica and on the Caribbean Islands, but increasingly rare southwards. At (150)300-1300(2300) $\mathrm{m}$ in the West Indies, (90)600-1700(3300) $\mathrm{m}$ in Mesoamerica, (150)400-2050 $\mathrm{m}$ in the Andes, and 
350-950 $\mathrm{m}$ in southeastern Brazil. In lowland and montane forests, clearings, on landslides, and along roadsides, often forming large colonies mixed with other species of Sticherus.

This common and widespread species is characterized by its long, pinnatifid aphlebiae, thin, grated-hyaline, basally hardening scales, and rectangular to twisted, contortedly ciliate scales abaxially on the axes. Specimens of this species were formely included in S. bifidus (e.g., by Moran, 1995), but that species has narrower bud scales with truncate bases, lacks aphlebiae and proximal internal segments on the basal 1-2 $\mathrm{cm}$ of each axis, has a matted-whitish indument, and has laxer, more appressed axis scales. Generally speaking, S. ferrugineus replaces $S$. bifidus further north, but there is considerable overlap in the ranges of both species.

There is some geographical variation in the coloration of the indument within S. ferrugineus. Specimens from Mexico are brilliantly orange while in the rest of Middle America the specimens are paler in color.

4. Sticherus cubensis (Underw.) J. Gonzales, comb. nov.

Dicranopteris cubensis Underw., Bull. Torrey Bot. Club 34: 253. 1907. Type. Cuba, Barbacoa, El Yunque, March, 1903, Underwood \& Earle 1416 (holotype, NY).

Plants medium-sized, slender. Rhizome 2-2.5 mm thick, dark brown, deciduously scaly, the scales narrowly lanceolate, $1.2-2 \times 0.2-0.3 \mathrm{~mm}$, dark-brown, the margins with irregularly arranged setae, cell texture stoutly hyaline to rigid with linearhexagonal cells. Petiole ca. $35 \mathrm{~cm}$ long and 3-4 mm thick, rough, dark brown. Rachis ca. $30 \mathrm{~cm}$ long between pinnae, aphlebiae long and narrowly trimerous, or absent. Fiddlehead 2-3.5 mm in diameter, densely scaly, the scales appressed, matted, dark orange to speckled with dark brown rows. Bud small, appressed, the scales narrowly lanceolate, basally truncate, apically usually glandular, $1.6-3 \times 0.3-0.4 \mathrm{~mm}$, orange to speckled with dark brown rows, the margins with few, delicate, contorted cilia 1/8 x the scale length, cell texture hyaline to mixed with hardened cells at the apices or in the center, the cells square to irregularly shaped. Pinnae $25-30 \mathrm{~cm}$ long, 3 -forked, $1^{\text {st }}$ axis $2.7-4.5 \mathrm{~cm}$ long and ca. $2 \mathrm{~mm}$ thick, shorter than the $2^{\text {nd }}$, not pectinate, $2^{\text {nd }}$ axis ca. $5 \mathrm{~cm}$ long and ca. $1 \mathrm{~mm}$ thick, not pectinate or only with distal scattered 
segments, $3^{\text {rd }}$ axis ca. $22 \mathrm{~cm}$ long and ca. $1 \mathrm{~mm}$ thick, pectinate-pinnatifid, lanceolate, bases unequally truncate, internal proximal segments absent, apically with gradually reduced segments, (3)4-5 cm wide, with ca. 2 segments per $\mathrm{cm}$; adaxially glabrous; abaxially deciduously scaly, the scales laterally arranged, linearlanceolate, apically glandular and usually twisted, 0.6-1 x 0.1-0.2 mm, orange to bicolorous with blackish apices, the margins with delicate and contorted cilia $1 / 3 \mathrm{x}$ the scale length, cell texture hyaline with hardened cells at the scale apices or centers, cells hexagonal. Segments (1.5)3-4 cm long and ca. $2 \mathrm{~mm}$ wide, linear from a dilatate base, apically obtuse, semi-chartaceous, the margins slightly revolute; adaxially glabrous; abaxially moderately scaly, the scales covering $40-60 \%$ of the leaf surface, arachnoid, 0.05-0.1 mm in diameter; veinlets thin, diverging, slightly raised; midvein scales deciduous, mixed, one type triangular to irregularly shaped, usually with glandular apices, ca. $0.2 \times 0.1 \mathrm{~mm}$, the margins with cilia $1-2 \times$ the scale length, the second type linear, ca. $1 \times 0.2 \mathrm{~mm}$, the margins with cilia $1 / 3 \times$ the scale length, both scale types whitish, lax-hyaline with irregular cells. Sori inframedial, superficially nested, 10-15 pairs per segment, 3-4 sporangia per sorus.

Distribution and ecology. Cuba. Ecology unknown.

This enigmatic species is for certainty only known from the type. It has an apical scale hardening pattern similar to that of $S$. decurrens, but the pinna arquitecture is similar to that of $S$. ferrugineus. It is conceivable that this represents a hybrid or a species of hybridogenic origin, but there is no unambiguous evidence for this. The taxonomy of S. bifidus and its allies on Cuba is highly complex, involving numerous taxa that hybridize and that have disjunct, slightly morphologically divergent populations. Detailed study is needed here.

5. Sticherus chocoensis J. Gonzales sp. nov.

Type. Colombia, Chocó, Istmia, Pepé, “cerca del río Peradó”, 1500 m, Fernández, García \& Velayos 8515, 5 May 1990 (holotype, BM).

Sticherus species statura delicata, pinnibus longe-lanceolatis, indumento paginae abaxialis segmentorum ferrugineo. Aphlebiae subtiles, tripartitae, squamae 
gemmorum basi induratae cellulis rotundatis, squamae costae stellatae margine ciliis induratis provisae.

Plants medium to large. Rhizome 2.5-3 mm thick, dark brown, deciduously scaly, the scales appressed, lanceolate, 3-4.5 x 1.5-2 mm, bicolorous, brown in the center with clear margins, the margins weak or ciliate, cell texture stoutly grated-hyaline, more rigid in the scale center, basally with rounded cells. Petiole ca. $70 \mathrm{~cm}$ long and $3 \mathrm{~mm}$ thick, dark brown, brittle. Rachis ca. $30 \mathrm{~cm}$ long between pinnae, subpaleaceus, aphlebiae long and narrowly trimerous. Fiddlehead ca. $6 \mathrm{~mm}$ in diameter, densely scaly, the scales appressed, dusty orange to brown, matted. Bud small, ascending, the scales narrowly lanceolate to linear, $1.4-3.2 \times 0.4-0.7 \mathrm{~mm}$, ca. 12 cells wide at the base, bicolorous orange-dusty with darker bases, the margins with slightly curled with cilia $1 / 8-1 / 3 \times$ the scale length, cell texture grated-hyaline to stoutly hyaline to rigid at the bases, the cells rectangular to irregular with dark and thicker cells walls, semiclathrate. Pinnae ca. 50-70 cm long, 2- to 3-forked, $1^{\text {st }}$ axis shorter than the $2^{\text {nd }}$, 3-5 cm long and 2-2.5 mm thick, only with proximal internal, overlapping segments adjacent to the aphlebiae, $2^{\text {nd }}$ axis ca. $8 \mathrm{~cm}$ long and $2 \mathrm{~mm}$ thick, when distal ca. 60 $\mathrm{cm}$ long, opposite axes of unequal length, partly or fully pectinate, $3^{\text {rd }}$ axis ca. $50 \mathrm{~cm}$ long and $1.5 \mathrm{~mm}$ thick, pectinate-pinnatisect, 5-10 cm wide with segments, long lanceolate with overlapping proximal and internal segments, with 3 segments per cm; adaxially scaly, the scales mixed, one type linear, basally hair-like, apically fringed, $0.8-1.8 \times 0.05-0.1 \mathrm{~mm}$, the second type square, $0.1-0.2 \times 0.05-0.1 \mathrm{~mm}$, the margins with numerous and straight with cilia 1-2 $\mathrm{x}$ the scale length, both scale types dark orange, cell texture grated-hyaline with linear to irregular cells; abaxially densely scaly, matted, the scales mixed, one type deciduous, arachnoid, appressed, the second type laterally arranged, spreading, linear lanceolate, apically fringed and/or glandular or extended to a long hair, 0.8-1.6 x 0.2-0.5 mm, the margins with cilia $1 / 4-1 / 2 \times$ the scale length, both scale types dark orange to cinnamon, cell texture grated-hyaline, the cells square to irregular. Segments $3-5 \times 2 \mathrm{~mm}$, linear, apically pointed, the margins narrowly revolute and ciliate with arachnoid scales; adaxially glabrous; abaxially sparsely scaly, the scales covering $20-35 \%$ of the leaf surface, arachnoid, 0.05-0.3 mm in diameter; veinlets thin, parallel, raised; midvein scales triangular to rhomboid, $0.2-0.4 \times 0.1-0.2 \mathrm{~mm}$, dark orange to cinnamon, the margins with thick 
and straight cilia 1/2-1 $\mathrm{x}$ the scale length (thus looking star-shaped when seen directly above the veins), cell texture grated-hyaline with well-defined irregular cells. 


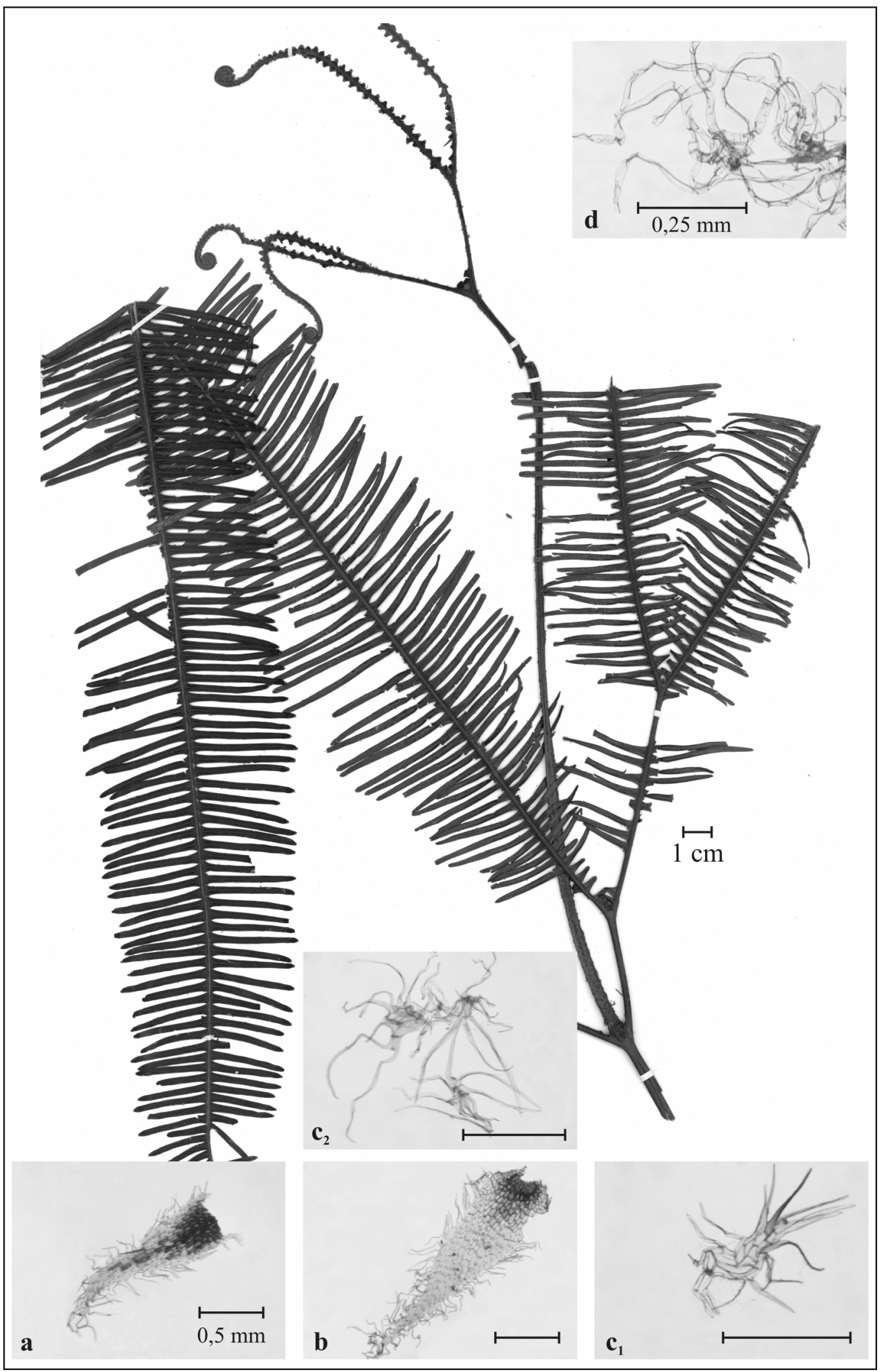

Fig. 12. Sticherus chocoensis J. Gonzales sp. nov., a) abaxial axis scales; b) bud scales, c1) midvein scales; c2) adaxial axis scales; d) arachnoid scales; Fernández, García \& Velayos 8515 (holotype, BM). 
Sori inframedial, restricted to the center of the segments, nested within arachnoid scales, 15-21 pairs per segment, 3-4 sporangia per sorus.

Distribution and ecology. In wet forest from sea level to $1500 \mathrm{~m}$ in western Colombia and adjacent Panama (Darién) and Ecuador (Esmeraldas), with a single record from Trinidad. Mostly grows in open situations, e.g., along roads, often on nutrient-deficient soils.

Sticherus chocoensis is a relatively delicate species with long-lanceolate and slender axes that is characterized by a completely orange-rusty indument, and starshaped, marginally hard-ciliate midvein scales. The specimens of $S$. chocoensis were previously identified as $S$. bifidus, but $S$. chocoensis is characterized in having aphlebiae, bearing proximal internal segments on the $1^{\text {st }}$ axes, in having overlapping segments on the distal axes, and in having grated-hyaline to basally rigid, strongly dusty to bicolorous bud scales. In contrast, S. bifidus lacks aphlebiae and internal proximal segments, has nonoverlapping segments, and has whitish, lax bud scales. In accordance with the harder scale texture, the marginal cilia in $S$. chocoensis are stouter and more widely spaced, while those of $S$. bifidus are much more delicate. This is perhaps most readily visible on the midvein scales, which in $S$. chocoensis appear distinctly star-shaped while those of S. bifidus are diffuse and appear lanose. Accordingly, both species can often be most easily distinguished by studying the abaxial midveins.

Sticherus chocoensis may also be confused with some specimens of $S$. ferrugineus, specially those from Mexico, by the similar orange-dusty indument coloration. However, S. ferrugineus has generally more robust axes, longer, laxer scales with rectangular cells, and pinnatifid aphlebiae, whereas $S$. chocoensis has shorter scales with rounded cells, and trimerous aphlebiae. Other similar species are S. maritimus and S. tepuiensis. The scales of $S$. chocoensis resemble those of $S$. maritimus in size and shape, but the latter species lacks the hardened cells that typically occur at the scale base in S. chocoensis. Sticherus tepuiensis, on the other hand, is much shorter, with shorter and usually completely rigid scales.

The only specimen of $S$. chocoensis with rhizomes shows very characteristic scales which are unique in the genus. They are rigid with dusty centers and whistish, 
hyaline margins that are highly abraded. All other species of Sticherus have concolorous or basally hyaline rhizome scales with usually well-preserved margins.

6. Sticherus interjectus (Jermy and T. Walker) J. Gonzales comb. nov.

Gleichenia interjecta Jermy \& T. Walker, Bull. Brit. Mus. (Nat. Hist.), Bot. ser. 13: 2. 1985. Type. Trinidad, Arima-Blanchisseuse Road, ca. $10^{\circ} 58^{\prime} \mathrm{N}, 61^{\circ} 10^{\prime} \mathrm{W}, 60 \mathrm{~m}$, Jermy 11164 (holotype, BM).

Plants large, semirobust. Rhizome ca. 1-3 mm thick, rough, with short squamophores, dark brown, the scales semideciduous, spreading, erect, linear-lanceolate, basally cordate, apically long-acuminate with 2 setae, 1.5-3 x 0.3-0.4 mm, dark orange to brown, the margins setose, cell texture rigid-subclathrate with rectangular to linear cells. Petiole 15-55 cm long and (1.5)3-4 mm thick, dark-brown, brittle. Rachis 10$25 \mathrm{~cm}$ long between pinnae, subpaleaceus with bicolorous to dark scales, aphlebiae trimerous with narrow, long segments, overlapping. Fiddlehead 2-3 $\mathrm{mm}$ in diameter, densely scaly, the scales appressed, matted, dark brown to speckled with dark brown rows. Bud small, ascending and opening rapidly, the scales lanceolate, basally rounded, apically narrowly long-acuminate with a long hair, (0.6)1.5-2.2 x (0.2)0.4$0.6 \mathrm{~mm}$, orange to bicolorous with brown bases and whitish margins, the margins with numerous, thick cilia 1/6-1/4 $\mathrm{x}$ the scale length, cell texture grated, stoutlyhyaline to centrally rigid, cells rounded. Pinnae $25-50 \mathrm{~cm}$ long, $2-$ to 3 -forked, $1^{\text {st }}$ axis shorter than the $2^{\text {nd }}, 5-10 \mathrm{~cm}$ long, remotely pinnatisect, segments interconnected by narrow, chartaceous wings, $2^{\text {nd }}$ axis, when plant 3 -forked often unequal, ca. $10 \mathrm{~cm}$ long, when distal ca. 20-40 cm long and 5-10 cm wide, pectinatepinnatisect, $3^{\text {rd }}$ and usually distal axis to ca. $45 \mathrm{~cm}$ long and 1.6-2(3) $\mathrm{mm}$ thick, 5-7 $\mathrm{cm}$ wide with segments, long-linear to lanceolate; adaxially deciduously scaly, the scales hair-like, ca. $1 \times 0.05-0.1 \mathrm{~mm}$, ca. 2 cell rows wide, orange to whitish, the margins with few cilia $1 / 5 \mathrm{x}$ the scale length, cell texture grated-hyaline, cells rectangular to linear; abaxially the scales covering $30-60 \%$ of the axes, mixed, one type appressed, triangular to rhomboid, apically fringed or glandular, 0.4-0.8 x 0.1$0.5 \mathrm{~mm}$, orange to whitish, margin with few, thick cilia 1-2 $\mathrm{x}$ the scale length, cell texture grated-hyaline, the cells rectangular to irregular, the second type laterally arranged, scattered, lanceolate with rounded to auriculate bases, apically long- 
aristate, $1-1.6 \times 0.3-0.5 \mathrm{~mm}$, up to 7 cell rows wide, dusty orange to bicolorous with bases and whitish margins, the margins with thick, curled cilia 1/5-1/3 $\mathrm{x}$ the scale length, cell texture stoutly hyaline to mixed, rigid in the center with stoutly hyaline margins, cells rectangular to linear. Segments (0.6)1-3.5 cm long and 2-2.5 mm wide, linear, pointed, chartaceous, the margins narrowly revolute, ciliate; adaxially glabrous; abaxially papillose and scatteredly scaly, the scales covering $15-25 \%$ of the surface; veinlets parallel, slightly raised, scatteredly scaly, the scales arachnoid to fibrillose, usually apically glandular, 0.5-1.5 x 0.01-0.05 mm; midvein scales triangular to rhomboid, apically fringed, 0.3-1.5 x 0.01-0.05 mm, orange to whitish, the margins with few, thick, straight cilia $1 / 2-1 \times$ the scale length, cell texture gratedhyaline with irregular cells. Sori medial, slightly nested in arachnoid scales, 10-21 pairs per segment, 3-4 sporangia per sorus.

Distribution and ecology. Forms mixed colonies with Sticherus ferrugineus and $S$. remotus along forest edges and roadsides at 60-300 m mainly in the northern mountain range of Trinidad. Also known from single specimens from Surinam and northern Venezuela, and to be looked for elsewhere where the parent species grow together, i.e., in Central America, northern South America, and the Caribbean Islands.

This species was described by Jermy and Walker (1985) based on a survey of the caryology of the S. bifidus complex in Trinidad. They recognized S. interjectus as a tetraploid of allopolyploid origin with $S$. ferrugineus and $S$. remotus as parent taxa. Accordingly, morphologically this species is intermediate between $S$. ferrugineus and $S$. remotus. It can be distinguished from $S$. ferrugineus by its robust growth with visibly thicker axes, longer and overlapping aphlebiae, more chartaceaous laminae, longer and often somewhat curved segments, and more remote segments on the 1st axis. Relative to $S$. remotus, this species has more closely spaced segments (except on the 1st axis), is larger and more robust, has generally larger scales, more and paler scales on the fiddleheads, and sometimes bears arachnoid scales on the abaxial segment surface. Further diagnostic characters are found among the scales. Typically, S. interjectus has scales on the buds and abaxially on the axes that are bicolorous with almost black scale bodies and whitish margins. The bud scales have widened bases and long-acuminate apices, whereas $S$. ferrugineus has uniformely 
lanceolate scales with square bases and $S$. remotus has short, triangular scales. The abaxial midvein scales are star-shaped, usually whitish, and sometimes have hardened, darkened cilia. Sticherus remotus has similar scales, while those of $S$. ferrugineus are larger and lax. Sticherus interjectus is also very similar to, and possibly conspecific with, $S$. nigropaleaceus, which see for further details.

Sticherus interjectus may also be confused with the triploid hybrid taxa occurring in Trinidad, $S$. x subremotus and $S$. x pseudobifidus. This is specially due to the fact that the hybrids are morphologically quite variable. Usually, they have axes of unequal length with somewhat irregularly placed segments. However, the main character distinguishing $S$. interjectus are the bud and adaxial axis scales that have more regularly defined outlines, cell patterns, and patterns of coloration. In $S$. x subremotus and $S$. x pseudobifidus adjacent scales on a given bud are highly variable with respect to shape and coloration and have irregular cell patterns. Jermy and Walker (1985) also described differences in the indument density on the abaxial segment surface between these three taxa, but closer examination of more specimens has convinced me that this is not a reliable character.

7. Sticherus nigropaleaceus (J. W. Sturm) J. Gonzales comb. nov.

Mertensia nigropaleacea J. W. Sturm, Fl. Bras. 2: 222. 1859. Gleichenia nigropaleacea (J. W. Sturm) Rosenst. Type. Brasil, Rio de Janeiro, Poeppig s.n. (holotype, B).

Plants large, semirobust. Rhizome 2.5-4 mm thick, rough, dark brown, the scales spreading, lanceolate with 2 apical setae, 1.5-2.5 x 0.2-0.3 mm, dark brown, the margins setose, cell texture rigid with rectangular cells. Petiole ca. $20-50 \mathrm{~cm}$ long and 1.5-3.5 mm thick, dark-brown, brittle. Rachis subpaleaceus, with orange to bicolorous-brown scales, aphlebiae pinnate to trimerous. Fiddlehead $1.5-3 \mathrm{~mm}$ in diameter, the scales appressed, matted, whitish to speckled with dark brown rows. Bud ascending and rapidly opening, the scales lanceolate to narrowly lanceolate, 1$2(3.2) \times 0.2-0.5(0.7) \mathrm{mm}$, usually bicolorous, basally orange with dark brown apices, the margins with cilia and setae $1 / 5$ to $1 / 10 \mathrm{x}$ the scale length, cell texture stoutly hyaline with rigid apices to entirely hardened. Pinnae $25-60 \mathrm{~cm}$ long, 2- to 3-forked, $1^{\text {st }}$ axis shorter than the $2^{\text {nd }}, 3.5-9 \mathrm{~cm}$ long, remotely pectinate, $2^{\text {nd }}$ axis $5-10 \mathrm{~cm}$ long 
when 3-forked, 20-45 cm long and 3-7 cm wide with segments when distal, opposite axes of unequal length, $3^{\text {rd }}$ axis ca. $45 \mathrm{~cm}$ long and 5-7 cm wide with segments, deeply pectinate to remotely pinnatisect, interconnected by slender, membranaceous wings projecting laterally from the axis, proximal internal segments long, overlapping, distal axes linear-lanceolate; adaxially with mixed, deciduous scales, one type irregularly shaped, $0.4-0.8 \times 0.1-0.5 \mathrm{~mm}$, the margins with cilia $1-2 \times$ the scale length, the second type ca. $1 \times 0.05-0.1 \mathrm{~mm}$, both scale types hyaline, whitish to orange; abaxially scatteredly scaly, the scales laterally arranged, covering 5-10(25)\% of the surface, narrowly lanceolate to triangular, long acuminate with fringed apices, $0.5-1.5(2) \times 0.1-0.3(0.6) \mathrm{mm}$, orange to bicolorous with dark-brown bases, the margins with thick cilia $1 / 3 \mathrm{x}$ and/or setae $1 / 5 \mathrm{x}$ the scale length, cell texture hyaline, rigid at the scale apices, with hexagonal cells. Segments 1-3(4) x 2-3 mm, linear from dilatate bases, apically obtuse, chartaceous, the margins slightly revolute and scatteredly ciliate; glabrous; veinlets parallel and slightly raised, loosely covered with reduced or simple hair-like scales; midvein scales triangular to rhomboid, 0.3$0.4 \times(0.06) 0.1-0.2 \mathrm{~mm}$, the margins with few and contorted cilia 1/2-1 $\mathrm{x}$ the scale length, cell texture grated-hyaline with irregular cells. Sori medial, loosely nested in arachnoid scales, 10-22 pairs per segment, 3-4 sporangia per sorus.

Distribution and ecology. Fairly common in humid forest at 300-800 $\mathrm{m}$ in southeastern Brazil, with isolated, outlying populations in southwestern Brazil (Mato Grosso do Sul) and Bolivia (La Paz). This peculiar geographical distribution pattern is also found in other unrelated plants, e.g., the cactus Rhipsalis cereuscula Haw. (Ibisch et al., 2000), and the bird genus Phibalura (Snow, 1982).

Sticherus nigropaleaceus is very similar to $S$. interjectus, and the only difference of importance between both taxa is the pattern of cell hardening on the scales of the bud and the lateral and abaxial axes. In S. nigropaleaceus the process of cell hardening and darkening proceeds from the scale apex towards the base, whereas in $S$. interjectus the process starts from the scale base. Both taxa may have some completely darkened scales, but close examination will always reveal some scales that are bicolorous. Sticherus nigropaleaceus further has somewhat less markedly revolute segment margins than $S$. interjectus. Since the pattern of cell hardening is an important character distingushing other species of Sticherus, e.g., S. decurrens and $S$. 
fulvus, at present I consider that this difference warrants the separation of $S$. nigropaleaceus and $S$. interjectus as distinct species. However, detailed cytological and/or molecular analyses would be desirable to confirm this.

8. Sticherus fulvus (Desv.) Ching, Sunyatsenia 5: 238. 1940.

Mertensia fulva Desv., Mém. Soc. Linn. Paris 6: 201. 1827. Dicranopteris fulva (Desv.) Underw., Bull. Torrey Bot. Club. 34: 255. 1907. Type. Jamaica, Blue Mts, collector unknown, (holotype, P).

Gleichenia brevipubis H. Christ., Bull. Herb. Bossier sér. 2, 6: 280. 1906. Sticherus brevipubis (H. Christ.) A.R. Smith, Amer. Fern. J. 70: 27. 1980. Type (designated by Lellinger, Proc. Biol. Soc. Wash. 89: 713. 1977). Costa Rica, Wercklé s.n. (lectotype, $\mathrm{CR}$; isolectotype, US).

Plants medium-sized, slender. Rhizome 1.8-2(3,5) mm thick, dark brown, deciduously scaly, the scales lanceolate with 2 apical setae, 1.4-1.6(2) x 0.3-0.4(0.5) $\mathrm{mm}$, dark-brown to reddish, the margins with irregularly arranged setae, cell texture rigid and sometimes hyaline at the bases with rectangular cells. Petiole $15-20 \mathrm{~cm}$ long and 2-3.5(4.5) $\mathrm{mm}$ thick, castaneous, brittle. Rachis 7-36 cm long between pinnae, subpaleaceus, the scales whitish to bicolorous with dark rows, aphlebiae absent or short and trimerous. Fiddlehead $1.5 \mathrm{~mm}$ in diameter, the scales matted, light brown-dark to speckled bicolorous with dark rows and dots. Bud small, appressed, the scales lanceolate, 0.3-1(2) x 0.2-0.8 mm, basally less than 15 cell rows wide, orange to bicolorous with dark apices or speckled with brown dots, the margins with delicate, contorted cilia $1 / 3 \times$ or setae $1 / 8-1 / 5 \times$ the scale length, cell texture grated lax-hyaline to mixed with usually rigid apices or with scattered darkened cells, cells rounded to rhomboid. Pinnae 25-50(60) cm long, axes 1 - to 3 -forked, $1^{\text {st }}$ axis $14-60 \mathrm{~cm}$ long, only with internal proximal segments, $2^{\text {nd }}$ axis (often unequally) 3$35(60) \mathrm{cm}$ long and $0.5-1,5 \mathrm{~mm}$ thick, when 3-forked, last axes 20-40 cm long, linear-lanceolate, with semicircular to wing-like proximal internal segments, $2-6 \mathrm{~cm}$ wide with segments, with 2-3 segments per $\mathrm{cm}$; scales adaxially deciduous, mixed, one type arachnoid, ca. 0.1-0.2 mm in diameter, the second type linear, $0.5 \times 0.05$ $\mathrm{mm}$, both scale types light orange to whitish, hyaline with rectangular or irregular 
cells; scales adaxially glabrous or with a mixture of arachnoid and linear scales, both scale types completely hyaline and whitish; abaxially moderately scaly, the scales usually mixed, one type on the surface, the scales ovate to star-shaped, ca. 0.2 in diameter, the second type lateral, lanceolate, 0.3-1.6 x 0.1-0.5 mm, basally about 4-8 cell rows wide, both scale types orange to bicolorous, grated hyaline to mixed with rigid apices, cells rectangular to irregular. Segments 0.8-2(40) x 2-3 mm, linear from a dilatate base, apically obtuse, chartaceous, the margins narrowly revolute; adaxially glabrous; abaxially scatteredly to densely scaly, the scales arachnoid, $0.05-0.4 \mathrm{~mm}$ in diameter, pale orange; veinlets diverging, obscure; midvein scales mixed, one type linear, $1-2 \times 0.05-0.01(0.1) \mathrm{mm}$, the margins with cilia $1 / 3 \times$ the scale length, the second type triangular to rhomboid, 0.2-0.4 $\times 0.1 \mathrm{~mm}$, the margins with numerous cilia 1-3 x the scale length, both scale types light orange, lax-grated hyaline, sometimes with star-shaped rigid parts (specimens from Jamaica), the cells irregular, globular. Sori inframedial, nested within arachnoid scales, 6-15(27) pairs per segment, 3-5 sporangia per sorus.

Distribution and ecology. A northern Neotropical species, widespread in Mesoamerica and the Caribbean: Mexico, Guatemala, Belize, Honduras, El Salvador, Nicaragua, Costa Rica, Panama, Cuba, Jamaica, Haiti, Dominican Republic, Puerto Rico, Guadeloupe, Dominica, Martinique, St. Lucia, and northern Colombia. Generally rather uncommon but locally abundant in montane forest, often along roadsides, forming large, uniform colonies, at (360)1400-2000 m.

This is a problematic species that was treated under the name of S. brevipubis by Smith (1975), Stolze (1976), Lellinger (1989), and Moran (1995). It is closely related and quite similar to $S$. bifidus, but is recognized by having reduced, rounded to winglike, distinct proximal internal segments, and by having completely dark or bicolorous, partly hardened bud, axis, and midvein scales. In comparison to $S$. bifidus, in $S$. fulvus these scales are fairly short, but with relatively larger cells, resulting in fewer cell rows across the scale bases ( $<15$ cells $v s .15-25$ cells in $S$. bifidus). The marginal cilia on the bud scales of $S$. fulvus are also quite characteristic. They are denser and more twisted than those of S. bifidus, which has more delicate cilia. On the hardened scale parts of $S$. fulvus the cilia are replaced by much shorter, 
stouter setae, whereas in S. bifidus and S. ferrugineus such hardened setae are lacking.

The arachnoid scales on the abaxial segment surface also show important differences relative to closely related species, namely, S. bifidus, S. ferrugineus, $S$. arachnoideus, $S$. aurantiacus, and $S$. brevitometosus. The arachnoid scales of $S$. fulvus are shorter and more closely adpressed to the segment surface than in the other taxa. As a result, the surface scales contrast at a first glance with the larger, more spreading ones on the midveins. This is not apparent in the other species. In common with $S$. ferrugineus, $S$. aurantiacus, and S. brevitomentosus, the arachnoid scales of $S$. fulvus are orangish in color (as indicated by the name), whereas $S$. bifidus and $S$. arachnoideus have whitish scales.

The pattern of hardening of the bud scales is geographically uneven in $S$. fulvus (Stolze 1976). Populations in Mexico and Costa Rica usually show an apical hardening with distinct dark upper and pale lower scale portions, while populations in Guatemala and the Caribbean islands show a mosaic pattern, with dark cells scattered over the scale surface and giving a speckled appearance. The taxonomic significance of this variation is unknown.

In South America, S. fulvus is generally replaced by S. brevitomentosus, which differs in having hyaline margins on the rigid bud scales, and in often lacking segments on the 1 st axes.

I have seen a number of putative hybrids between $S$. fulvus and $S$. ferrugineus. These are recognized by having the general size and aspect of $S$. ferrugineus and by bearing aphlebiae, but have reduced, rounded internal proximal segments and partly hardened bud scales showing the typical pattern of S. fulvus. In fact, the lectotype of $S$. brevipubis selected by Lellinger (1977) is atypical of $S$. fulvus in bearing well-developed aphlebiae. It may well represent a hybrid involving S. ferrugineus. In this case, it would strinctly speaking not be a synonym of $S$. fulvus. However, since caryological studies cannot be conducted on the herbarium material, this problem is likely to remain unresolved. 
9. Sticherus fuscus J. Gonzales sp. nov.

Type. Costa Rica, Limón, Cordillera de Talamanca, Atlantic slope, Cerro Tararia, 2400-2600 m, “elfin forest”, 10 Sep 1984, G. Davidsen et al. 28845 (holotype, MO; isotype, CR).

Sticherus species statura pro genere media, frondes $15-30 \mathrm{~cm}$ longae, aphlebiae breves, simplices. Rhachides squamulis fuscis persistentibus provisae, rhachides distales breves, lamina lanceolata, segmentis planis indumento (in pagina abaxiali) dense arachnoideo rufo-brunneo, rhachides abaxiales squamis lateralibus fuscis instructae.

Plants small to medium-sized. Rhizome unknown. Petiole 2-3 mm thick, reddish brown, brittle. Rachis ca. $14 \mathrm{~cm}$ long between pinnae, subpaleaceus, the scales erect, dark brown, aphlebiae short, simple. Fiddlehead ca. $3 \mathrm{~mm}$ in diameter, matted, the scales dense, spreading, orange to dark reddish brown. Bud ascending and opening rapidly, the scales lanceolate, 1.6-2.6 x 0.4-0.6 mm, brilliant orange to reddish brown, the margins with short setae or with cilia $1 / 10 \mathrm{x}$ the scale length, cell texture stoutly hyaline to rigid with hexagonal cells or ill-defined and dark. Pinnae $15-30 \mathrm{~cm}$ long, 2- to 3 -forked, $1^{\text {st }}$ axis $3.5-5 \mathrm{~cm}$ long and ca. $2 \mathrm{~mm}$ thick, not pectinate, $2^{\text {nd }}$ axis 1.5-3 cm long and ca. $1.5 \mathrm{~mm}$ thick, with gradually reduced, usually overlapping internal segments, $3^{\text {rd }}$ axes $12-20 \mathrm{~cm}$ long and ca. $1.5 \mathrm{~mm}$ thick, fully pectinatepinnatisect, narrowly lanceolate, $2-3.5 \mathrm{~cm}$ wide with segments, with 2-3 segments per cm; adaxial scales deciduous, mixed, one type rectangular, ca. $0.2 \times 0.05 \mathrm{~mm}$, the second type arachnoid, $0.05 \mathrm{~mm}$ in diameter, both scale types orange to whitish, hyaline; abaxial scales lateral, narrowly lanceolate, apically fringed, 1-2 x 0.3-0.4 $\mathrm{mm}$, brilliant orange to reddish brown, the margins with cilia $1 / 5 \mathrm{x}$ the scale length or with short setae, basally hyaline and usually with rigid apices. Segments oblong, chartaceous, 1-3.2 x 1-1.5 mm, flat; adaxially glabrous; abaxially densely scaly on midvein and veinlets; midvein scales mixed, one type linear, 1-2 x 0.05-0.01(0.1) $\mathrm{mm}$, orange, hyaline, the margins with few cilia, the second type triangular to square, 0.3-0.6 $\times 0.3-0.4 \mathrm{~mm}$, orange to dusty, the margins with cilia $1 / 2 \times$ the scale length, hyaline with rigid apices, the cells square to irregular; veinlets raised, completely covered with scales, the scales arachnoid, matted, brilliant orange to reddish. 


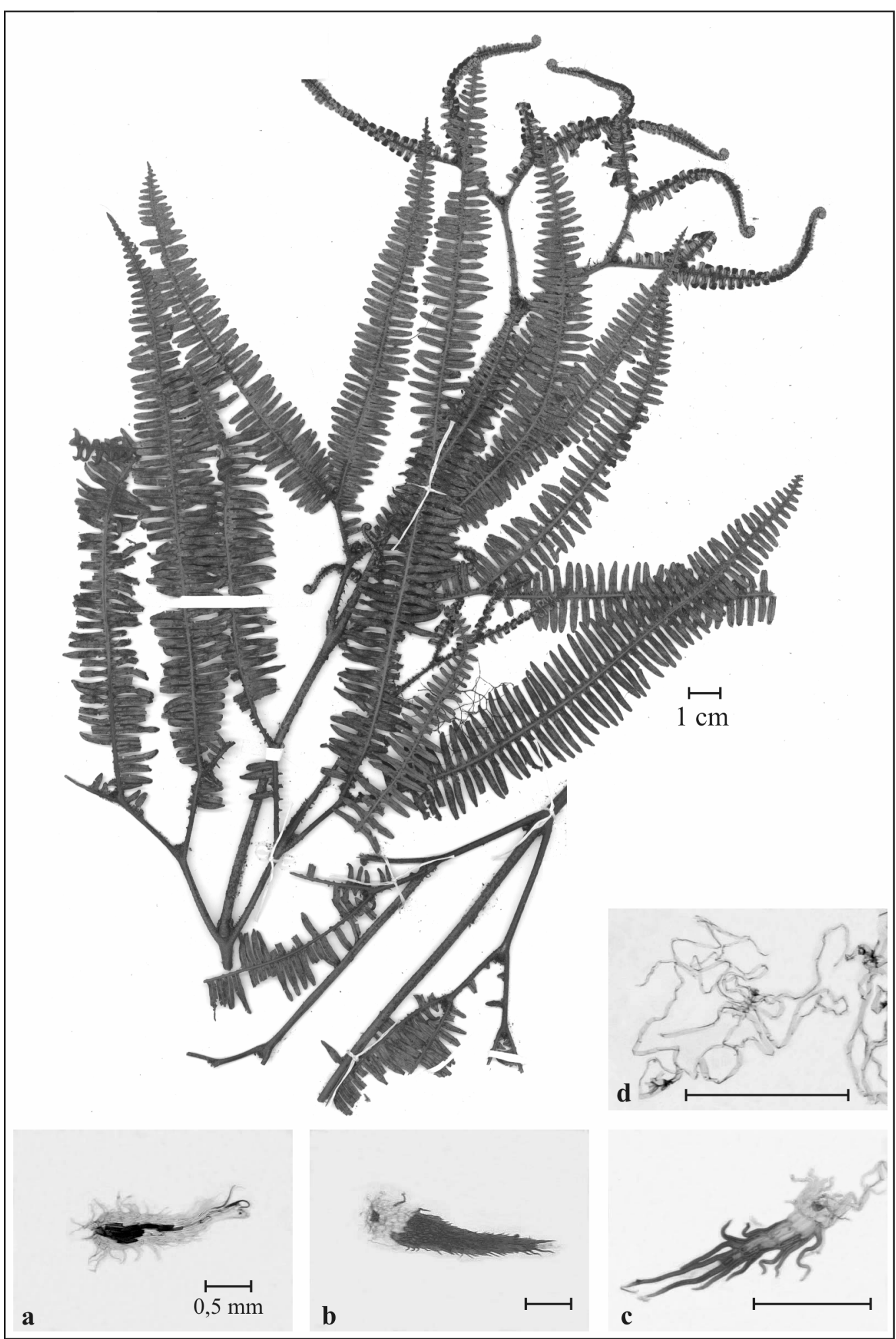

Fig. 13. Sticherus fuscus J. Gonzales sp. nov., a) abaxial axis scales; b) bud scales; c) midvein scales; d) arachnoid scales; Davidsen et al. 28845 (holotype, MO). 
Sori inframedial, nested within arachnoid scales, 6-15(27) pairs per segment, 3-5 sporangia per sorus.

Distribution and ecology. Endemic to the Cordillera de Talamanca in Costa Rica; to be looked for in adjacent Panama. Rarely collected, in disturbed humid montane forest (with Quercus spp.) at 2400-2500 m.

Sticherus fuscus is a medium-sized species with $15-30 \mathrm{~cm}$ long pinnae, short, simple aphlebiae, persistent dark scales on the rachis, rather short, lanceolate distal axes with flat segments, and abundant, dark lateral scales on the abaxial axes. These dark axial scales contrast with the dusty-colored arachnoid scales of the segment surfaces. The bud scales are narrowly lanceolate and mostly rigid with hyaline bases while the midvein scales are rectangular and only apically rigid (specially the proximal ones).

Sticherus fuscus may be confused with S. brevipubis, S. tepuiensis, $S$. aurantiacus, and S. fulvus. The first of these species differs from S. fuscus in being larger overall, having much more reduced or even lacking aphlebiae, reduced internal proximal segments on all axes (i.e., the segments do not overlap as in S. fuscus), more revolute segment margins, and paler segment scales. Sticherus tepuiensis lacks aphlebiae, has narrower and longer axes, glabrous rachises, and has shorter and scattered lateral scales abaxially on the axes. Sticherus aurantiacus differs in having longer, more linear distal axes, reduced proximal internal segments, and has scales of generally paler, more matted colors and laxer texture. The pattern of scale hardening of $S$. fuscus resembles that of $S$. fulvus, and specially specimens with strongly rigid scales of the latter species may be confused with S. fuscus. However, S. fulvus is larger overall, has shorter and more ovate scales, more strongly reduced, auricle-like, non-overlapping proximal internal segments, and usually lacks aphlebiae.

Sticherus fuscus is only known from two collections from Costa Rica Still, I do not hesitate in describing it as new, because it has several distinct diagnostic characters (see above). It is very unlikely that the type specimens represents a hybrid, because the only potential parent taxa in Costa Rica would be $S$. brevipubis and $S$. ferrugineus and the confirmed hybrids I have seen between these two species are much larger than S. fuscus and have larger aphlebiae. It is, however, conceivable that S. fuscus hybridises with S. fulvus, because some specimens placed under that 
species have unusually dark axial scales as well as atypically large internal proximal segments. The confusion surrounding this species complex (see also Stolze, 1981) can only be resolved through a detailed biosystematic study involving cytotaxonomic and molecular data.

A collection from Guyana (Cuyuni-Mazaruni Region, Mt. Ayanganna, 2 km transect along summit ridge, $05^{\circ} 23^{\prime} \mathrm{N}, 59^{\circ} 59^{\prime} \mathrm{W}, 1800-2000 \mathrm{~m}$, Henkel 105, U, US) is similar to S. fuscus in size, shape of the axes and segments, and in the general scale coloration and patterns. It differs somewhat in having less rigid scales, bicolorous bud scales with hyaline margins, and less divided pinnae. Considering the geographical distance between both collections, with closely related S. tepuiensis occurring between them, and the slight, but potentially significant morphological differences, I am hesitant to include this specimen under $S$. fuscus. On the other hand, I find no marked differences that would warrant placing it in a taxon of its own.

10. Sticherus tepuiensis A.R. Sm., Ann. Missouri Bot. Gaard. 77: 253. 1990.

Type. Venezuela, Bolívar, Meseta del Jaua, Cerro Sarisariñama, "porción NE, bosque enano por encima y al borde de la Sima Mayor", 441'40”N, 64¹3'20”'W, 1320 m, 13 Feb 1974, Steyermark et al. 109036 (holotype, US).

Plants small to medium-sized. Rhizome unknown. Petiole 1.5-3.5 mm thick, castaneous, brittle. Rachis $15-25 \mathrm{~cm}$ long between pinnae, subpaleaceus, with appressed scales, aphlebiae absent. Fiddlehead ca. $5 \mathrm{~mm}$ in diameter, loosely scaly, the scales dusty orange. Bud small, appressed, the scales triangular-lanceolate, 0.8$1.6 \times 0.3-0.6 \mathrm{~mm}$, brilliant orange to reddish brown, the margins with short, irregularly arranged cilia and/or setae, cell texture stoutly hyaline to rigid. Pinnae 30$50 \mathrm{~cm}$ long, 2- to 3-forked, $1^{\text {st }}$ axis 4-7 cm long and 1.5-2 mm thick, not pectinate, $2^{\text {nd }}$ axis $3-5(10) \mathrm{cm}$ long and $1-1.5 \mathrm{~mm}$ thick, only with semicircular to winglike internal segments, $3^{\text {rd }}$ axis linear, 25-55 $\mathrm{cm}$ long and $1.5 \mathrm{~mm}$ thick, pinnatisect, 3-4 $\mathrm{cm}$ wide with segments, with 2.5-3 segments per $\mathrm{cm}$, basally with wing-like internal segments; the scales adaxially deciduous, arachnoid, triangular, or rounded, ca. $0.1 \mathrm{x}$ 0.1-0.05 mm, orange to bicolorous with dark margins, the margins with cilia 1-2 $\mathrm{x}$ the scale length ciliate, sometimes some cilia hard and brown, cell texture hyaline; 
abaxial scales lateral, triangular to narrowly lanceolate with two curled and semirigid apical cilia, $0.6-1.2 \times 0.3-0.5 \mathrm{~mm}$, dusty orange to reddish-brown, cell texture stoutly hyaline to rigid, cells square with thick cell-walls. Segments 1-1.7 cm long and 2-3 $\mathrm{mm}$ wide, oblong, the margins flat to narrowly revolute, deeply pinnatisect to slightly remote; adaxially glabrous; abaxially with thick midveins and parallel, raised veinlets, densely scaly; midvein scales triangular and rectangular, 0.2-0.4 x 0.1-0.2 $\mathrm{mm}$, dusty orange to reddish brown, stoutly hyaline to semirigid, the margins with cilia 1/2 the scale length; veinlet and surface scales arachnoid, 0.01-0.05 $\mathrm{mm}$ in diameter, forming a matted surface, pale orange to reddish brown, hyaline to stoutly hyaline. Sori inframedial, filling the entire segment, slightly nested in arachnoid scales, 15-25 pairs per segment, 3-4 sporangia per sorus.

Distribution and ecology. Endemic to montane forest at 1300-2100 $\mathrm{m}$ in southeastern Venezuela in Bolívar (Cerro Jaua, Cerro Sarisariñama) and Amazonas (Cerro Duida).

Sticherus tepuiensis is a medium-sized species (pinnae $25-50 \mathrm{~cm}$ long) lacking aphlebiae, it is usually pectinate only on the distal axes and has linear, short segments. The internal proximal segments may either be gradually reduced and winglike (as in S. fulvus and S. aurantiacus), or lacking (as in S. bifidus). Important characters for the identification of Sticherus tepuiensis are found in the color, shape, and texture of the scales. All scales are stoutly hyaline to rigid with clearly differentiated cells and with a tendency towards apical hardening. In accordance with the pattern of apical hardening, the scales are often basally ciliate and apically setose. Possibly, the degree of hardening is correlated with elevation, with darker scales predominating at higher elevations. The bud scales generally appear black to the naked eye while the scales of the axes and midvein are scattered and appressed. The midvein scales are short, triangular in outline, and have straight, sometimes darkened marginal cilia. 
11. Sticherus aurantiacus Østergaard \& B. Øllgaard, Flora of Ecuador, No. 66 pp.124-125, 2001.

Type. Ecuador, Morona-Santiago, road Santa Susana de Chiaviasa-Panecillo, 1300 m, Øllgaard \& Navarrete 2670 (holotype, QCA; isotype, AAU).

Plants large, slender. Rhizome 2-3.5 mm thick, dark brown to black, sparsely scaly, the scales lanceolate, 1-3.5 $\times 0.4-0.8 \mathrm{~mm}$, dark-brown to reddish, the margins setose, cell texture rigid with rectangular cells. Petiole ca. 20 long and $2.5-5 \mathrm{~mm}$ thick, castaneous to stramineus, subpaleaceus. Rachis ca. 15-20 cm long between pinnae, subpaleaceus, the scales bicolorous, aphlebiae absent. Fiddlehead 3-5 $\mathrm{mm}$ in diameter, the scales matted, light brown-dark or speckled with dark. Bud small, ascending, opening rapidly, the scales narrowly lanceolate, apically fringed and/or glandular, (0.7)1.2-2.5 x 0.3-0.5 mm, bicolorous, dark brown in the center and orange to whitish on the margins, the margins with setae or with long, delicate, contorted cilia $1 / 2-1 \mathrm{x}$ the scale length, cell texture usually mixed, stoutly hyaline to rigid in the center, marginally hyaline, the cells rectangular. Pinnae ca. $25-50 \mathrm{~cm}$ long, axes 2- to 3-forked, $1^{\text {st }}$ axis (when 3-forked) longer than 2 nd axis, (3)4-6 cm long and 1.5-2 mm thick, brittle, 2nd axis $2-10 \mathrm{~cm}$ long and ca. $1.5 \mathrm{~mm}$ thick, when distal, 30-40 cm long, opposite axes often unequal in length, $3 \mathrm{rd}$ axes $20-35 \mathrm{~cm}$ long and $0.5-1.5 \mathrm{~mm}$ thick, the 1st (usually the proximal two) axes not pectinate or only with internal proximal, semicircular to winglike segments, distal axes pinnatisect, with wing-like internal segments, lacking segments on the first $1-2 \mathrm{~cm}$ from the bud, 1.5-3(4) cm wide with segments, linear, usually with 2-3 segments per cm; adaxial scales deciduous, square to rhomboid, (0.2)0.4-1(1.6) x 0.1-0.2 mm, orange to brown bicolorous, the margins ciliate; abaxially moderately scaly, usually with mixed scales, one type on the axis surface, reduced, appressed, 0.1-0.6 $\times 0.01-0.2 \mathrm{~mm}$, the second type lateral, narrowly lanceolate to linear, $1-2(3) \times 0.2-0.5 \mathrm{~mm}$, orange to bicolorous, the margins with long, twisted cilia $1 / 2 \times$ the length of scale, cell texture hyaline to hardened in the center and/or on the apex, the cells long, rectangular. Segments narrowly rectangular, semichartaceous, 0.9- 30 × 2-4 mm, the margins narrowly revolute; veinlets slightly raised; adaxially glabrous; abaxially moderately to densely scaly, the scales arachnoid, 0.3-0.6 x ca. $0.1 \mathrm{~mm}$; midvein scales mixed, one type narrowly rectangular, $0.4-0.8 \times 0.1-0.2 \mathrm{~mm}$, the second type linear, apically 
fringed, $1-2 \times 0.05-0.1 \mathrm{~mm}$, hyaline or light orange, the margins with dense, twisted cilia $1 / 2 \times$ the scale length. Sori medial, nested within arachnoid scales, 7-14 pairs per segment, 4 spotangia per sorus.

Distribution and ecology. Disjunctedly along the eastern Andean slope in S Colombia (Serranía La Macarena), S Ecuador (Zamora-Chinchipe) to N Peru (San Martín), and Bolivia (La Paz). Locally common at 750-2500 $\mathrm{m}$ in disturbed montane forest, along roadsides, and along streams, often forming large, uniform colonies.

Sticherus aurantiacus is characterized by its large, reddish, arching axes, small, trimerous aphlebiae, highly reduced, winglike proximal internal segements on the segment-bearing axes, long-lanceolate, bicolorous, dark-centered, long-ciliate bud scales, fimbriate, hyaline or bicolorous (dark-centered) abaxial axis scales, dense, matted, highly dissected, arachnoid scales on the segment surface, fimbriate, lax-hyaline midvein scales.

An important character of Sticherus aurantiacus is the reduction or lack of the internal proximal segments. In this character it resembles $S$. fulvus and $S$. brevitomentosus, but the abaxial axis and bud scales differ between the three species. $S$. aurantiacus has centrally hardened scales, $S$. fulvus has a mosaic pattern, and $S$. brevitomentosus has a basal patterns. Further, the scale margins are always hyaline and densely long-ciliate in $S$. aurantiacus, while in the other two species the margins are hardened as well. Similar dark-centered scales are found in closely realted $S$. fuscus, which differs in having larger, sometimes even overlapping proximal internal segments, and linear, straight axes. A further related species is $S$. tepuiensis which shares the large, arching axes and the reduced proximal internal segments with $S$. aurantiacus, but which has smaller, triangular to rounded, appressed midvein scales with grated-hyaline cell texture and hardened margins, and reddish brown to cinnamon abaxial segment scales. In contrast, the midvein scales of $S$. aurantiacus are large, fimbriate, lax-hyaline to apically hardened, and the surface scales are pale orange. Among the closely related species S. fulvus, S. fuscus, S. aurantiacus, and $S$. tepuiensis, $S$. aurantiacus has the largest, least rigid scales. 
12. Sticherus maritimus (Hieron.) Nakai, Bull. Natl. Sci. Mus. Tokyo 29: 23. 1950.

Gleichenia maritima Hieron., Bot. Jahrb. Syst. 34: 562. 1905. Dicranopteris maritima (Hieron.) Maxon, Contr. U.S. Natl. Herb. 24: 49. 1922. Type. Colombia, El Valle, Buenaventura, Lehmann 4432 (lectotype, B, designed by Lellinger, Proc. Biol. Soc. Wash. 89: 714. 1977).

Plants small. Rhizome 1.5-2 mm thick, dark brown, sparsely scaly, the scales narrowly lanceolate, usually with glandular apices, (0.4)0.8-1.3 x 0.2-0.3 mm, dark brown, the margins setose, cell texture rigid-subclathrate with square cells. Petiole (7.5)9-20 cm long and 1-2 mm thick, castaneous, rough, subpaleaceus. Rachis ca. 5$15 \mathrm{~cm}$ long between pinnae, the scales spreading, dark orange, aphlebiae absents. Fiddlehead ca. $0.5 \mathrm{~cm}$ in diameter, the scales dense, matted, dusty orange. Bud small, appressed, the scales lanceolate to triangular, apically long-ciliate or glandular, (0.6)0.8-1.6 x (0.2) 0.4-0.6 mm, orange, the margins with numerous slightly curled and twisted cilia $1 / 3 \mathrm{x}$ the scale length, cell texture grated-stoutly hyaline with rounded cells. Pinnae 15-30 cm long, 1- to 2-forked, $1^{\text {st }}$ axis when 2-forked 1-2.5(10) $\mathrm{cm}$ long and 0.5-1.5 mm thick, usually with short, rounded segments, $2^{\text {nd }}$ or distal axis 10-25 cm long and 0.5-1 mm thick, linear, pinnatisect, $0.6-1 \mathrm{~cm}$ wide with segments, with ca. 3-3.5 segments per cm; scales adaxially mixed, one type linear, ca. $1 \times 0.1 \mathrm{~mm}$, second type star-shaped to rectangular, $0.2-0.6 \times 0.05-0.2 \mathrm{~mm}$, both scale types whitish with orange centers, hyaline to slighly rigid with rectangular to irregular cells; abaxially and laterally moderately to densely scaly, the scales ovate to broadly rectangular, apically long-ciliate or glandular, (0.4)0.8-1.6 x (0.1)0.2-0.6 $\mathrm{mm}$, orange, the margins with straight, spreading cilia $1 / 7-1 / 3 \times$ the scale length, the cells hyaline, hexagonal. Segments $0.25-0.5 \mathrm{~cm}$ long and $1.5-2 \mathrm{~mm}$ wide, rounded to oval, the margins chartaceous and ciliate, proximal segment gradually reduced; veinlets not raised; adaxially usually with weak scales; abaxially densely scaly; midvein scales ovate to broadly rectangular, apically glandular to tufted, ca. $0.3 \mathrm{x}$ $0.1 \mathrm{~mm}$, ca. 3 cell rows wide, orange, the margins with cilia $1 / 2-1 \mathrm{x}$ the scale length, cell texture grated hyaline; abaxial surface and veinlets densely scaly, the scales mixed, one type arachnoid, the second type triangular to ovate, $0.2-0.4 \times 0.01-0.2$ $\mathrm{mm}$, the margins with cilia $1 / 2-3 \mathrm{x}$ the scale length, both scale types orange to dusty, 
hyaline. Sori medial, densely nested within arachnoid scales, 3-4(5) pairs per segment, 3-4 sporangia per sorus.

Distribution and ecology. Endemic to and apparently rather uncommon on the western Andean slope in Colombia and northern Ecuador (Esmeraldas), along open banks in montane forest at 400-1000 m.

Sticherus maritimus is characterized by its short size, rounded to ovate, revolute segments, densely scaly abaxial segments surfaces with orange to dusty scales, aggregate petioles, and subclathrate rhizome scales. Of all Neotropical species of Sticherus with dense arachnoid scales on the abaxial segment surface, $S$. maritimus is the shortest. Because of this reduced size, the rhizomes are clumped and the petioles appear to be aggregated. The petioles are very long relative to the segments, usually being longer than the individual axes. The segment shape may resemble $S$. revolutus, but that species lacks arachnoid scales abaxially on the segments and has midvein scales that are linear-lanceolate. Sticherus revolutus also tends to occur at higher elevations than S. maritimus. In S. maritimus, most scales, including those of the rhizome, have apical glands and are always grated-hyaline without hardened cells. The shape of the scales resembles that of $S$. chocoensis, which, however, generally has basally hardened and darkened scales. The coloration of the scales also reminds of $S$. rufus, but the scale type in that species is quite different, with larger scales bearing long, lax cilia and with much longer cells.

13. Sticherus rufus J. Gonzales \& A. R. SM sp. nov.

Type. Venezuela, Portuguesa, Ospino: 11-12 km WNW of La Estación, road to Palma Sola, ca. 9²7’N, 69³5’W, ca.1300 m. 10. Nov.1982, Smith 1139 (holotype, UC; isotypes, MO, PORT, UNELLEZ).

Folia tripartita ad sexies partita, rachidibus circiter aequilongis, perfecte pectinatis, laminis (pinnis) linearibus, segmentis oblongis, parvis, aphlebiis simplicibus. Indumentum densum e squamis apice fimbriatis margine longe ciliatis, cellulis elongatis indistinctis; squamae rhizomatis splendide aureo-brunneae, linearilanceolatae, cellulis valde indistinctis. 
Plants medium-sized. Rhizome 3-3.5 mm thick, dark brown, the scales persistent, spreading, linear-lanceolate, basally slightly auriculate, apically long-acuminate with 2 setae, 1.2-2.8 x 0.3-0.5 mm, golden-orange to bicolorous with dark-brown scale centers, the margins with irregularly arranged setae, cell texture rigid with linear cells. Petiole ca. 20-40 cm long and (1.5)2.5-3.5(4.5) mm thick, light-castaneous. Rachis (7.5)12-35 cm between pinnae, subpaleaceus, aphlebiae simple, longer than the adjacent internal segments, usually overlapping. Fiddlehead 4-9 $\mathrm{mm}$ in diameter, densely scaly, the scales brilliant orange. Bud small to medium-sized, ascending, opening rapidly, the scales lanceolate, basally rounded, apically acuminate, fringed, (0.6)1.5-2(3) x 0.2-0.6 mm, basally approximately 18 cells wide, golden and brilliant orange, the margins with irregularly arranged, slightly curled cilia (1/7)1/4-1/2 $x$ the scale length, cell texture grated-hyaline, cells rectangular to narrowly elongate.

Pinnae 25-40(60) cm long, 3- to 5-forked, $1^{\text {st }}$ axis shorter than the $2^{\text {nd }}, 3-11 \mathrm{~cm}$ long, opposite pairs of equal length, only with internal segments, $2^{\text {nd }}$ and $3^{\text {rd }}$ axes equal in size, (4)10-20(35) $\mathrm{cm}$ long and 0.6-1.5 mm wide, pectinate-pinnatisect, (1.5)2-3(4) cm wide with segments, with ca. 3 segments per $\mathrm{cm}$, when 4 - to 5 -forked, $4^{\text {th }}$ and $5^{\text {th }}$ axes linear, shorter than the previous, fully pectinate, proximal internal segments gradually reduced; adaxially withscattered, mixed scales, one type linear, 0.8$1.5(2.7) \times 0.05-0.1 \mathrm{~mm}$, the margins apically with cilia $1 / 4 \times$ the scale length, the second type reduced, $0.06-0.2 \times 0.03-0.1 \mathrm{~mm}$, the margins with cilia $1-2 \times$ the scale length, both scale types brilliant orange, grated hyaline with long rectangular cells; abaxially with mixed scales, one type on the axis surface, deciduous, narrowly triangular to linear, 0.4-0.6 x 0.06-0.2 mm, the second type lateral, basally truncate, apically usually long-fringed to $0.1 \mathrm{~mm}, 1.5-2 \mathrm{~mm} \times 0.1-0.3 \mathrm{~mm}$, both scale types brilliant orange, sometimes darker at the apices, the margins with irregularly arranged, spreading cilia 1/5-1/2 $\mathrm{x}$ the scale length, cell texture grated hyaline, with rectangular or linear cells. Segments oblong, (1.5)3-10(19) x 1.5-2.5 mm, the margins slightly revolute, chartaceous, the margins abaxially ciliate; veinlets parallel, slightly raised; adaxially glabrous; abaxially densely scaly on midvein and veinlets; midvein scales linear to narrowly triangular, apically usually glandular, (0.1)0.3-0.6(1.3) x (0.03)0.06-0.1 mm, brilliant orange, the margins with spreading cilia (1/2)1-2 $\mathrm{x}$ the scale length, cell texture lax, grated hyaline with rectangular to irregular cells; abaxial surface densely scaly, the scales mixed, one type arachnoid, the second type 


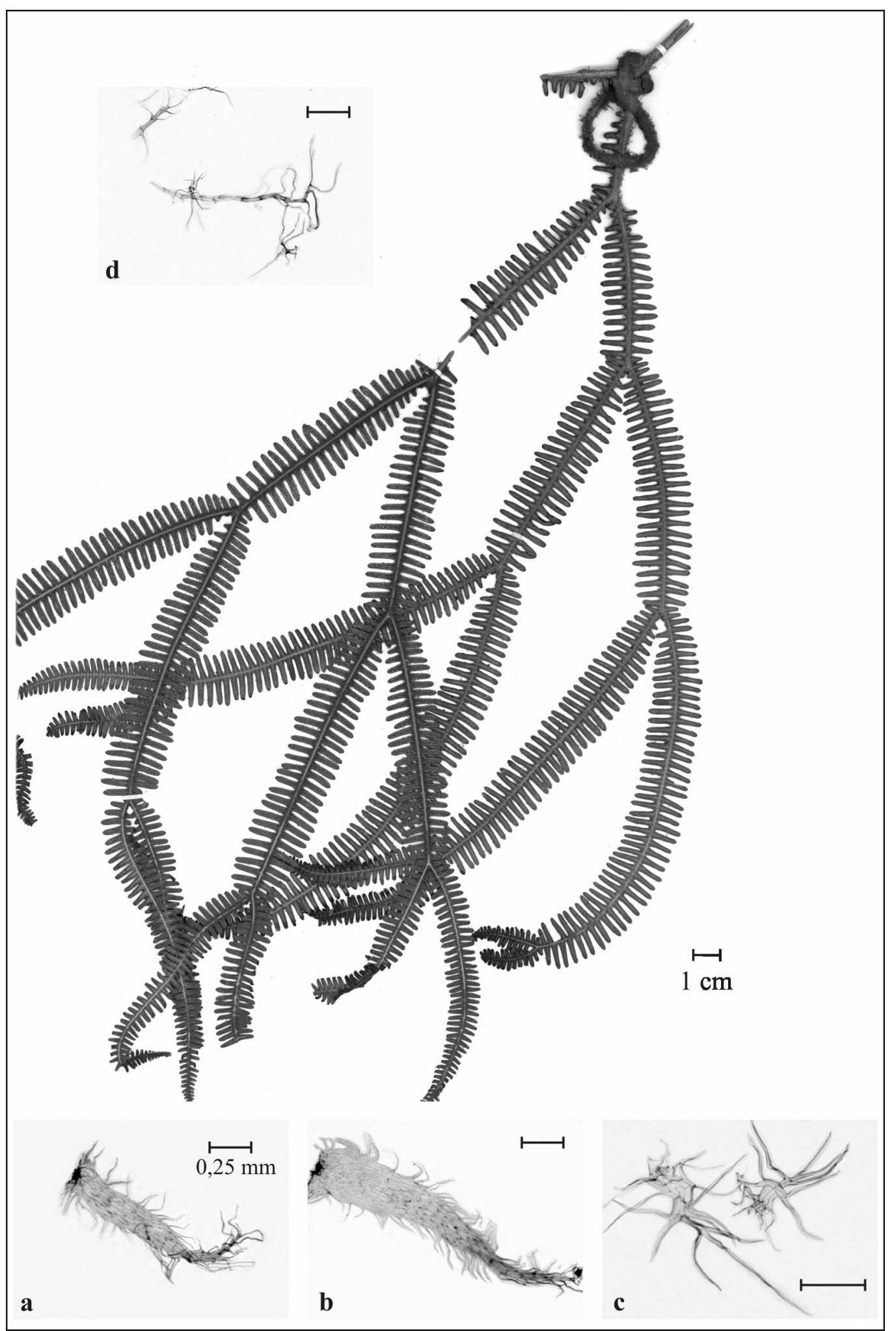

Fig. 14. Sticherus rufus J. Gonzales \& A. R. Smith sp. nov., a) abaxial axes scales; b) bud scales; d) midvein scales. Smith 1139 (holotype, UC). 
linear, 0.2-0.4 x 0.05-0.1 mm, pale orange, lax-hyaline, the margins with cilia 1/2-2 $\mathrm{x}$ the scale length. Sori medial, superficially nested within a few arachnoid scales, 810(15) pairs per segment, 3-4 sporangia per sorus.

Distribution and ecology. El Salvador, northwestern Venezuela and adjacent Colombia, in wet montane forest areas, often forming colonies at forest borders, and on steep, sunny slopes, 1000-1500(3200) m.

Sticherus rufus is a characteristic species with highly divided pinnae (3- to 6forked), linear, fully pectinate axes of roughly similar length, oblong segments, and short, simple aphlebiae. The indument consists of linear-lanceolate, hyaline, brilliant orange, apically fringed scales with long marginal cilia and ill-defined, elongate cells. The rhizome scales are inear-lanceolate, brilliantly golden-brown, and with a barely discernable cell texture.

Relative to otherl species of the genus, the scale color is reminiscent of $S$. chocoensis, S. tepuiensis, and S. maritimus, but all these species differ in numerous respects. Sticherus chocoensis has grated-hyaline to basaly rigid scales, much longer segments, and trimerous aphlebiae. S. tepuiensis is shorter, lacks aphlebiae, and has rigid, dark scales. The dark scales are specially conspicuous on the buds, which can look almost completely black. S. maritimus is much shorter with the axes on 1- to 2forked. It further has oblong segments and lacks aphlebiae.

14. Sticherus arachnoideus Østergaard \& B. Øllgaard, Flora of Ecuador 66: p. 121. 2001.

Type. Ecuador, Zamora-Chinchipe, Rio Sabanilla, at hydroelectric plant $1.5 \mathrm{~km} \mathrm{~W}$ of Sabanilla, 1800 m, Øllgaard 100745 (holotype, AAU; isotypes, NY, UC, US)

Plants medium-sized to large, semirobust. Rhizome 3.5-4 mm thick, dark brown, densely scaly, the scales falcate, linear-lanceolate, (1.5)3.5-6 x 0.4-0.8(1) mm, brown, the margins with thin, curled setae, cell texture rigid, base hyaline with very narrow to linear cells, younger scales often hyaline margins. Petiole 3.5-6 mm thick, castaneous to beige, subpaleaceus. Rachis $15-25 \mathrm{~cm}$ long between pinnae, subpaleaceus, usually with dark brown scales, aphlebiae simple. Fiddlehead ca. 3-4 
$\mathrm{cm}$ in diameter, densely scaly, matted, whitish. Bud large, ascending, opening rapidly, the scales lanceolate to linear, basally truncate, (1.2)1.8-2.5 x 0.4-0.5 mm, dusty whitish to to bicolorous with dark orange bases, the margins with delicate and slightly curled cilia $1 / 4 \mathrm{x}$ the scale length, cell texture grated, stoutly-hyaline, darkened cells restricted to the scale base and center, the cells hexagonal; the shape and size of the bud scales are quite consistent in a given plant. Pinnae $25-50 \mathrm{~cm}$ long, 3-forked, $1^{\text {st }}$ and $2^{\text {nd }}$ axes similar in size, 2-6 cm long and 1-2.5 mm thick, with simple aphlebiae, $1^{\text {st }}$ axis not pectinate, $2^{\text {nd }}$ axis with scattered proximal internal segments, specially on younger axes, $3^{\text {rd }}$ axis linear, 16-36 cm long and 1-1.5 mm thick, pectinate-pinnatifid, (1.2)1.7-3 cm wide with segments, with ca. 3 segments per cm; scales adaxially linear to triangular, $1.5 \times 0.2 \mathrm{~mm}$, the margins ciliate; scales abaxially and laterally dense, lanceolate to linear, apically fringed, (1)1.6-2 x 0.3-0.4 $\mathrm{mm}$, beige to transparent, the margins with transparent, curled cilia 1/4-1/3 the scale length, the cells elongate-oval to irregular. Segments oval, semi-chartaceous, 8-15 x 2-4 mm, the margins somewhat revolute; scales adaxially similar to those adaxially on the axes, sparse, but specially on younger pinnae covering up to $25-50 \%$ of the leaf surface; scales abaxially and marginally arachnoid, densely covering the entire surface, $0.1 \times 0.1-0.5 \mathrm{~mm}$, whitish; midvein scales dense, triangular to rhomboid, the margins with cilia 1-2 $\mathrm{x}$ the scale length, hyaline-whitish, cell texture grated-hyaline, irregular. Sori medial, not nested within scales but protected by the abaxial scales, 410 pairs per segment, 3-4 sporangia per sorus.

Distribution and ecology. Locally common in the Andes of Colombia (Caldas) and southwestern Ecuador (Loja, Morona-Santiago, Zamora-Chinchipe) at 1300-2700 m. In montane forests, clearings, on ridges, and along roadsides, often forming mixed colonies with S. tomentosus.

Sticherus arachnoideus is a little-known species that is recognized by the linear, narrow last axes with uniform segments, and by lacking segments and bearing simple aphlebiae on the 1 st and the 2 nd axes. The entire abaxial surface has a dense, whitish indument, specially on the axes, where the scales overlap. The scale pattern is similar to that of $S$. hispaniolensis, but the scales of $S$. arachnoideus are generally more hyaline with numerous, delicate, longer marginal cilia. Both species further differ in the relative length and segment disposition of the axes. In S. arachnoideus, 
the basal two axes lack segments and are of roughly similar length, while in $S$. hispaniolenis, they are pectinate (at least the 2nd axis) and the 2nd axis is conspicuously longer than the 1st and may even approach the length of the distal axis. Sticherus arachnoideus might also be confused with S. tomentosus, but that species has much longer segments, shorter scales with a more rigidly hyaline cell texture and shorter, broader marginal cilia (specially on the bud and lateral scales).

15. Sticherus tomentosus (Cav. ex Sw.) A.R. Smith, Ann. Missouri Bot. Gard. 77: 255. 1990.

Mertensia tomentosa Cav. ex Sw., Kongl. Vetensk. Acad. Nya Handl. 25: 177. t. 5, f. 4. 1804. Gleichenia tomentosa (Cav. ex Sw.) Spreng., Syst. Veg. 4: 27. 1827. Type. Peru, collector unknown (holotype, S, hb. Cavanilles; US photo).

Plants large, robust. Rhizome 3.5-4 mm thick, dark brown; densely scaly, the scales falcate, ovate-lanceolate, acuminate with 1-2 thin apical setae, 2.8-4.5 x 0.6-1 mm, brown, the margins entire or with thin setae, cell texture rigid with linear, superficially striated cells. Petiole ca. $30 \mathrm{~cm}$ long and 3.5-6.5 mm thick, castaneous, rough, subpaleaceus. Rachis 10-40 cm long between pinnae, the scales usually bicolorous, orange with dark brown bases, aphlebiae simple to pinnatifid with a long segment. Fiddlehead $1.5-2 \mathrm{~cm}$ in diameter, the scales dense, matted, bicolorous with dark brown bases or completely dusty brown. Bud large, ascending and opening rapidly, the scales lanceolate to ovate with rounded to cordate bases, (1.6)2.5-3(5) $\mathrm{x}$ (0.4)0.8-1.2 mm, gradually bicolorous with dark brown bases and dusty orange apices and margins, the margins with numerous, slightly curled, unequally arranged cilia 1/9-1/4 x the scale length, cell texture stoutly hyaline to mixed with rigid bases or entirely dark, the shape and size of the bud scales are quite consistent in a given plant. Pinnae 30-50(80) cm long, 2- to 3-forked, $1^{\text {st }}$ axis $6.5-8.5 \mathrm{~cm}$ long and 2-3(4) $\mathrm{mm}$ thick, not pectinate or with scattered internal segments, $2^{\text {nd }}$ axis longer than the $1^{\text {st }}$, usually distal, (10)35-60 cm long and 1.5-2.5 mm wide, deeply pinnatifid, 4$8.5(12) \mathrm{cm}$ wide with segments, ca. 2 segments per $\mathrm{cm}, 3^{\text {rd }}$ axis lanceolate, (25)35-55 $\mathrm{cm}$ long and 1.2-1.5 mm thick, pectinate, with segments 4-6 $\mathrm{cm}$ wide; scales adaxially mixed, one type rectangular, sometimes with an apical hair, 0.2-0.4(0.6) x $0.05-0.2(0.6) \mathrm{mm}$, the margins with cilia $1 / 2-2 \mathrm{x}$ the scale length, the second type 
linear, apically fringed, 1.2-2(5) x 0.1-0.2 mm, 2-3(5) cell rows wide at the base, the margins with cilia ca. 1/5-1/3 x the scale length, both scale types hyaline or mixed with some hardened cell walls, the cells rectangular to linear; abaxially and laterally moderately to densely scaly, the scales long-lanceolate, usually with cordate bases and tufted apices, 0.6-2.5(4) x 0.1-0.4-0.6(0.8) mm, about 10 cell rows wide at the base, dusty orange to bicolorous with dark brown basis, the margins with spaced, unequal, thin cilia (1/11)1/6-1/4 x the scale length, cell texture opaque-hyaline with narrowly hexagonal to linear cells, usually forming a striated to vermiculate surface. Segments cylindrical, (1.5)3-6(10) cm long and 2.5-4(5) mm wide, subchartaceous, the margins flat to somewhat revolute, ciliate; adaxially with sparse, deciduous, matted scales similar to those of the adaxial axis; abaxially with parallel raised veinlets that are conspicuous despite densely scaly surface, the scales arachnoid, matted, 0.2-0.4 x (0.01)0.05-0.2 mm, orange to brown and marginal ones whitish; midvein densely scaly, the scales proximally narrowly-lanceolate and distally roundlanceolate, apically fringed, (0.4)0.8-(1)1.6 x 0.1-0.3 mm, opaque orange, the margins with numerous, curled cilia 1/5-1/3 x the scale length, cell texture hyaline with rectangular to irregular cells. Sori inframedial to medial, restricted to the segments centers, superficially nested within arachnoid scales or not, 13-35 pairs per segment, 3-5 sporangia per sorus.

Distribution and ecology. Mountains of Guatemala, the Guyana highlands in southeastern Venezuela and adjacent Guyana, and the Andes in northwestern Venezuela, Colombia, Ecuador, and Peru. Locally common along humid forest edges, along roads, on landslides, and along streams at 1700-3000 m.

Sticherus tomentosus forms the geographical center of a complex closely related species that have traditionally been considered to belong to a single, variable species, variously including the names $S$. blepharolepis, $S$. buchtienii, S. lanosus, and S. velatus (Tryon \& Stolze 1989, Østergaard \& Øllgaard 2001). In their study of the genus in Ecuador, Østergaard \& Øllgaard (2001) recognized S. blepharolepis as distinct species. Closer examination of the variability of the group over its entire geographical distribution has convinced me that six morphologically and geographically distinct entities can be recognized, that are here treated as distinct species. In addition to $S$. tomentosus and S. blepharolepis, these are S. hispaniolenis, 
S. jacha, S. lanosus (incl. S. buchtienii), and S. velatus. All these species share a robust growth form, large scales, trimerous to pinnatifid aphlebiae, densely scaly rachises, and arachnoid scales abaxially on the segments. Because of the complexity of this group, the differences between the six species are summarized here (Tab. 1, Fig. 15).

Some of the most important differences among the species are found in the size and shape of the scales (Fig. 15). These are most conspicuous among the midvein scales, where $S$. velatus has by the far narrowest, almost fibrillose scales. Sticherus tomentosus occupies the opposite side of the spectrum, with very wide midvein scales. Between these two extremes are four species with midvein scales of medium width that differ in length: $S$. hispaniolensis has very short scales, $S$. blepharolepis with scales of medium length, and S. lanosus and S. jacha cover a wide range of scale lengths. Relative to the axis scales, several species are quite distinct. Sticherus hispaniolenis has short, narrow scales whose measurements barely overlap with those of S. tomentosus and S. blepharolepis. Sticherus velatus has narrow scales that are mostly narrower than those of $S$. tomentosus and $S$. blepharolepis, but overlaps completely with S. lanosus. In general, the range of axis scale sizes of $S$. lanosus covers almost the entire variability within these six species, except for the longest scales of $S$. tomentosus, $S$. jacha, and S. blepharolepis. Among the bud scales, the overlap between the species is even more pronounced. This is because the shape of these scales is highly consistent in the entire species group and because within a given plant the bud scale size varies on buds of different orders of axial dividions, with more distant buds always having shorter scales. However, despite these problems, there are certain differences in the bud scales between the species. Sticherus blepharolepis, S. jacha, and S. lanosus tend to have the largest scales, while the other three species have shorter scales. It is conspicuous that the relative sizes of scales between the five species are not constant between the different scales types. Sticherus tomentosus, which has the largest axis and broadest midvein scales, has relatively short bud scales, while $S$. velatus, which has the narrowest midvein and very short axis scales, tends to have larger bud scales than $S$. tomentosus. Overall, the least distinctive species with respect to scale parameters is S. lanosus, which in most cases covers almost the entire size range of all other species combined. However, this species is characterized by other characters, e.g., its short segments; midvein scales with tufts of apical cilia, long 2nd axes, and a dense 
indument abaxially on the segments. Other characters are summarized in table 1 and discussed under the respective species.

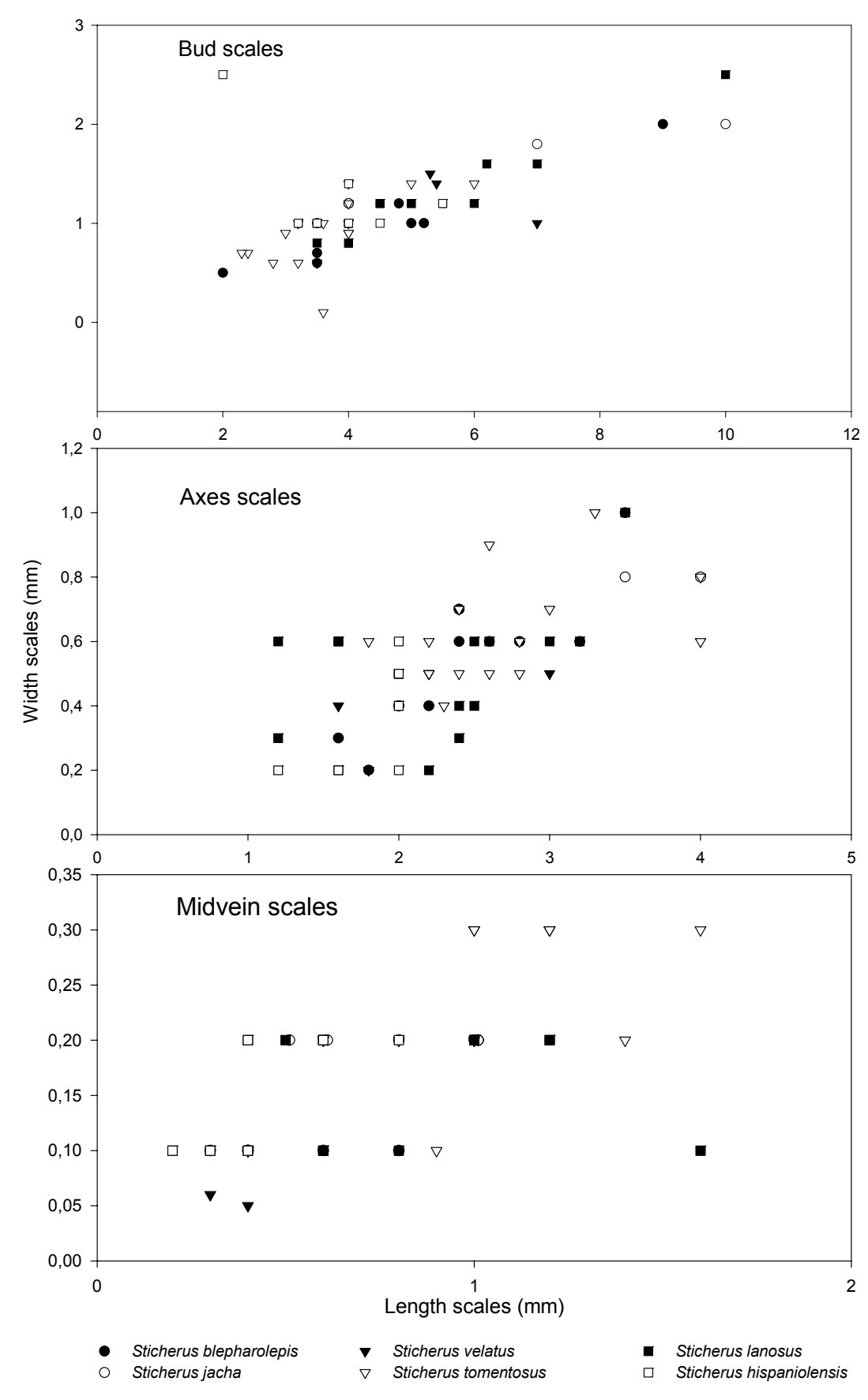

Fig. 15. Scale length and width of axis (a), bud (b), and midvein (c) scales of five closely related species of Sticherus: S. belpharolepis (closed circles), S. jacha (open circles, S. velatus (closed triangles), S. tomentosus (close triangles), S. lanosus (closed squares), S. hispaniolenis (open squares). 
Sticherus tomentosus, in the restricted sense used here, is characterized by its long-lanceolate, thick axes, large, basally pinnatifid to linear aphlebiae, large fiddleheads with conspicuous scales, densely scaly rachis with usually dark-brown scales, a dense, orange to dark orange indument abaxially on the segments, strikingly large proximal scales on the midvein, and parallel, thin, raised veinlets. Sticherus tomentosus may be confused with $S$. lanosus, but that species has much shorter segments (1.5-3 cm vs. (2.5)4-6 cm long), is 3- to 4-forked (vs. usually 2-forked in $S$. tomentosus), and has sparser, paler indument. Another similar species is $S$. velatus, specially in the zone of geographical overlap in Peru and Bolivia, but $S$. velatus has much narrower scales, specially on the midveins, than S. tomentosus. Sticherus tomentous may also be confused with $S$. chocoensis because of their similar indument coloration and size of the axes, but $S$. chocoensis has shorter, laxer scales with grated-hyaline (vs. linear) cells texture, and star-shaped midvein scales. 
Table 1. Comparative characters of Sticherus tomentosus and its close allies.

\begin{tabular}{|c|c|c|c|c|c|c|}
\hline & S. blepharolepis & S. jacha & S. velatus & S. tomentosus & S. lanosus & S. hispaniolensis \\
\hline $\begin{array}{l}\text { Length axis scales } \\
(\mathrm{mm})\end{array}$ & s 1.6-3.2 & $2-4$ & $1.6-3$ & $1.8-4$ & $1.2-3.5$ & $1.2-2$ \\
\hline $\begin{array}{l}\text { Width axis scales } \\
(\mathrm{mm})\end{array}$ & $0.2-0.7$ & $0.4-1$ & $0.2-0.5$ & $0.5-1$ & $0.3-1$ & $0.2-0.5$ \\
\hline $\begin{array}{l}\text { Axis scale color } \\
\text { and cell texture }\end{array}$ & $\begin{array}{l}\text { whitish, stoutly } \\
\text { hyaline }\end{array}$ & $\begin{array}{l}\text { speckled to } \\
\text { bicolorous }\end{array}$ & $\begin{array}{l}\text { whitish to } \\
\text { bicolorous }\end{array}$ & $\begin{array}{l}\text { orange, grated- } \\
\text { hyaline }\end{array}$ & $\begin{array}{l}\text { pale orange, } \\
\text { grated } \\
\text { hyaline }\end{array}$ & $\begin{array}{l}\text { opaque whitish, } \\
\text { stoutly hyaline }\end{array}$ \\
\hline $\begin{array}{l}\text { Length bud scales } \\
(\mathrm{mm})\end{array}$ & $2-9$ & $3.5-10$ & $3.5-5.5(7)$ & $2.3-4(6)$ & $2.4-4.5(10)$ & $3.5-5.5(7)$ \\
\hline $\begin{array}{l}\text { Width bud scales } \\
(\mathrm{mm})\end{array}$ & $0.5-2$ & $1-1.8$ & $0.6-1.4$ & $0.7-1.4$ & $\begin{array}{l}(0.2) 0.8- \\
1.2(2.5)\end{array}$ & $0.6-1$ \\
\hline $\begin{array}{l}\text { Bud scale cell } \\
\text { texture }\end{array}$ & basally rigid & basally rigid & $\begin{array}{l}\text { stoutly } \\
\text { hyaline }\end{array}$ & basally rigid & basally rigid & Stoutly hyaline \\
\hline $\begin{array}{l}\text { Length midvein } \\
\text { scales (mm) }\end{array}$ & $0.4-1$ & $0.5-1$ & $0.3-0.4$ & $0.6-1.6$ & $(0.3) 0.6-1.6$ & $(0.2) 0.4-0.8$ \\
\hline $\begin{array}{l}\text { Width midvein } \\
\text { scales (mm) }\end{array}$ & $0.1-0.2$ & 0.2 & $0.05-0.1$ & $0.1-0.3$ & $0.06-0.2$ & $0.1-0.2$ \\
\hline $\begin{array}{l}\text { Midvein scale } \\
\text { color and cell } \\
\text { texture }\end{array}$ & $\begin{array}{l}\text { brilliant orange } \\
\text { to whitish, } \\
\text { hyaline or with } \\
\text { rigid apices }\end{array}$ & bicolorous & $\begin{array}{l}\text { whitish, } \\
\text { hyaline }\end{array}$ & $\begin{array}{l}\text { dusty orange, } \\
\text { grated hyaline }\end{array}$ & $\begin{array}{l}\text { orange, } \\
\text { hyaline }\end{array}$ & whitish, hyaline \\
\hline $\begin{array}{l}\text { Length of cilia } \\
\text { (relative to scale } \\
\text { length) }\end{array}$ & $1 / 3-1 x$ & $1 / 3-1 / 2$ & $1-3$ & $1 / 5-1 / 2$ & $1 / 3-3$ & $1 / 2-1$ \\
\hline No. axis divisions & & $3-4$ & (3) 4 & $2(3)$ & $3(4)$ & (3) 4 \\
\hline $\begin{array}{l}\text { Relative size of } \\
\text { axes }\end{array}$ & $1^{\mathrm{st}}>2^{\mathrm{nd}}$ & $1^{\text {st }}>2^{\text {nd }}$ & $1^{\text {st }}<2^{\text {nd }}$ & $1^{\text {st }}<2^{\text {nd }}$ & $1^{\text {st }}<2^{\text {nd }}$ & $1^{\text {st }}</=2^{\text {nd }}$ \\
\hline $\begin{array}{l}\text { Length of } \\
\text { segments }(\mathrm{cm})\end{array}$ & $2.5-4$ & $2-3$ & $1.5-2$ & $2.5-6$ & $1.5-3$ & $2-3$ \\
\hline $\begin{array}{l}\text { Width of } \\
\text { segments (mm) }\end{array}$ & $2.5-4.5$ & $2-3$ & 3 & $3.5-4.5$ & $3-4.5$ & $2-3.5$ \\
\hline $\begin{array}{l}\text { Depth of segment } \\
\text { division }\end{array}$ & $\begin{array}{l}\text { pinnatisect to } \\
\text { remote }\end{array}$ & $\begin{array}{l}\text { remote to } \\
\text { deeply } \\
\text { pinnatifid }\end{array}$ & pinnatifid & pinnatifid & pinnatifid & pinnatifid \\
\hline $\begin{array}{l}\text { No. veinlets / } \\
\text { segment }\end{array}$ & $30-40$ & $28-35$ & $23-30$ & $40-60$ & $11.5-15.5$ & $10-16$ \\
\hline Distribution & Ecuador-Bolivia & Bolivia & Peru-Brazil & Guyanas-Peru & Peru-Brazil & Hispaniola \\
\hline Elevation (m) & $1500-2700$ & $1900-2750$ & $900-2000$ & $1250-2800$ & $850-2500$ & $915-2040$ \\
\hline
\end{tabular}


16. Sticherus lanosus (H. Christ) J. Gonzales comb. nov.

Gleichenia lanosa H. Christ, in Schwacke, Pl. Nov. Mineiras 2: 35. 1900. Type. Brazil, Minas Gerais, Schwacke 12475 (holotype, P; photo, US, BM).

Gleichenia buchtienii H. Christ \& Rosenst., Repert. Spec. Nov. Regni Veg. 5: 229. 1908. Sticherus buchtienii (H. Christ \& Rosenst.) Copel., Ann. Cryptog. Phytopatol. 5: 28. 1947. Type. Bolivia, "Yungas australis, Sirupaya prope Yanacachi", Buchtien 496 (holotype, not located, isotype, US).

Plants large, robust. Rhizome 3.5-5 mm thick, dark brown, densely to moderately scaly, the scales lanceolate, acuminate, 1.7-4.7 x 0.4-0.8 mm, dark orange, the margins setose, cell texture rigid with linear cells. Petiole ca. $30 \mathrm{~cm}$ long and 3-6 mm thick, castaneous, subpaleaceus. Rachis ca. 10-30 cm long between pinnae, paleaceus, scales bicolorous orange and dark brown at the bases, aphlebiae pinnatifid with a long central segment. Fiddlehead ca. $1.5 \mathrm{~cm}$ in diameter, densely scaly, the scales pale orange to bicolorous with dark brown bases. Bud large, ascending and opening rapidly, scales (1.5)2.4-3.5(7) x 0.4-0.9(1.7) mm, narrowly lanceolate, gradually bicolorous with opaque dark brown bases to dusty orange, the margins with numerous delicate and slightly curled cilia $1 / 5-1 / 8 \times$ the scale length, cell texture stoutly hyaline to mixed with dark bases or entirely darkened, the cells hexagonal to linear, forming a vernicose texture, darkened cells usually restricted to the scale base; the shape and size of the bud scales are quite consistent in a given plant. Pinnae 46-60(75) cm long, 3- to 4-forked, $1^{\text {st }}$ axis shorter than the $2^{\text {nd }},(2) 8-13$ $\mathrm{cm}$ long and 2-3 mm thick, not pectinate or only with proximal internal, gradually reduced segments adjacent to the aphlebiae, $2^{\text {nd }}$ axis $4-10 \mathrm{~cm}$ long and $1-2 \mathrm{~mm}$ thick, deeply pinnatifid, ca. $3-5 \mathrm{~cm}$ wide with segments, $3^{\text {rd }}$ axis longer than or equal in length to the $2^{\text {nd }},(25) 35-55 \mathrm{~cm}$ long and $1.2-1.5 \mathrm{~mm}$ thick, pectinate, $2-4 \mathrm{~cm}$ wide with segments, with ca. 2-2.7 segments per $\mathrm{cm}$, the first proximal internal segments overlapping, the remaining segments gradually reduced; distal axes are narrower than the previous and linear-lanceolate; adaxially scaly, the scales mixed, one scale type rectangular, $0.2-0.8 \times 0.2 \mathrm{~mm}$, the second type linear to hair-like, ca. $2 \times 0.01 \mathrm{~mm}$, both scale types hyaline and sometimes with darkened cells (specially due to hardened cell walls), the cells rectangular to linear or irregular; abaxially moderately 
to densely scaly, the scales lateral, lanceolate, long acuminate, (0.8)1.4-2(3) x (0.2)0.5-0.8 $\mathrm{mm}$, pale orange to whitish, the margins with twisted, irregularly arranged cilia, cell texture stoutly hyaline with hexagonal to linear cells, forming a verniculose surface, sometimes ill-defined. Segments (7)20-30(48) x 3-4(5) mm, oblong, subchartaceous, the margins slightly revolute to flat; adaxially glabrous; abaxially moderately scaly, the scales arachnoid, orange; midvein scales lanceolate, acuminate, apically fringed, (0.3)0.6-1.5 x ca. 0.06-0.1(0.2) $\mathrm{mm}$, orange to whitish, hyaline, the margins with few, thin cilia 1/2-1 x the scale length; scales of the margins fimbriate, around the sori arachnoid, orange. Sori medial, not reaching segment apex, densely nested within arachnoid scales, (8)16-21(35) pairs per segment, 3-5 sporangia per sorus.

Distribution and ecology. Mountains in Ecuador (Carchi), Peru, Bolivia, and southeastern Brazil. Locally common (specially in Bolivia) along roadside, on stream banks, and on landslides in humid montane forest at 850-2450 m.

Sticherus lanosus is closely related S. tomentosus, but differs in being 3forked (2-forked in S. tomentosus, rarely 3-forked in a few specimens from Peru), in its narrower pinnae, and its linear-lanceolate, fringed, apically long-ciliate, whitish midvein scales (ovate-lanceolate with a simple acuminate apex, dusty golden-orange in $S$. tomentosus). In S. lanosus the relative length of the axes is fairly similar, while in S. tomentosus, the 1st axes are much shorter than the distal ones. Sticherus lanosus has a more southerly distribution than $S$. tomentosus but both overlap in their distribution in Ecuador and Peru.

Sticherus lanosus is most similar to geographically remote $S$. hispaniolensis from Hispaniola, but the latter has laxer, shorter, more ovate midvein scales. Sticherus lanosus may also be confused with $S$. velatus, but that species all scales are narrower and have longer, more curled cilia, the midvein scales are fibrillar, and the axes diverge at a wider angle, leading to a more open, palmate appearance of the plants. 
17. Sticherus hispaniolensis J. Gonzales sp. nov.

Type. Dominican Republic, Prov. La Estrelleta, Sierra de Neiba, 31-34 km by road NNW of La Descubierta, 11-14 km N of Angel Felix, 1850-1900 m, 21 Feb 1983, Mickel 8748 (holotype, NY).

Affinis S. lanoso, differt squamis rhachidis et costae laxioribus et pallidioribus, cellulis squamarum rhachidis rotundatis, marginibus ciliis longioribus et tenuioribus provisis.

Plants large, robust. Rhizome (2)3-5 mm thick, dark orange to brown, densely to moderately scaly, the scales narrowly lanceolate, long acuminate, 3-6 x 0.4-0.8 mm, dark orange, the margins with thin setae, cell texture semi-rigid with linear cells. Petiole 3-6 mm thick, castaneous. Rachis ca. 15-25 cm long between pinnae, paleaceous, scales pale orange to whitish or bicolorous with dark orange at the bases; aphlebiae simple or pinnatifid with a long central segment. Fiddlehead ca. $1.5 \mathrm{~cm}$ in diameter, densely scaly, the scales large, pale orange to bicolorous. Bud medium sized, appressed, the scales lanceolate with rounded bases, 1.5-2(3) x 0.4-0.6(1) mm, gradually bicolorous with dark orange bases and whitish margins, the margins always hyaline with numerous, delicate, , slightly curled cilia $1 / 5-1 / 8 \mathrm{x}$ the scale length, cell texture grated, stoutly-hyaline to mixed with semi-rigid bases, the cells rectangular to narrowly hexagonal; the shape and size of the bud scales are quite consistent in a given plant. Pinnae 30-60 cm long, 3-(4-)forked, $1^{\text {st }}$ axis 6-11 cm long and 2-2.5 mm thick, occasionally with scattered proximal internal segments adjacent to the aphlebiae, $2^{\text {nd }}$ axis (3.5)6-15 $\mathrm{cm}$ long and 1.5-2 $\mathrm{mm}$ thick, opposite axes of unequal length, longer than the $1^{\text {st }}$ and ca. $1 / 3-1 / 2 \times$ the length of the distal axis, pinnatifid, $3^{\text {rd }}$ axis $20-35 \mathrm{~cm}$ long and 1-1.5 mm thick, deeply pinnatifid, (1.8)2.5-4.5 $\mathrm{mm}$ wide with segments, with 2.5-3 segments per $\mathrm{cm}$, proximal internal segments gradually reduced, not overlapping, fusiforme to acerose; scales adaxially mixed, one type arachnoid, 0.2-0.8 $\times 0.2 \mathrm{~mm}$, the second type linear, ca. $2 \times 0.01 \mathrm{~mm}$, whitish, usually with dark centers, cell texture hyaline with rectangular-linear to irregular cells; abaxially moderately scaly, the scales lanceolate with rounded bases or narrowly lanceolate with truncate bases, $1-2 \times 0.2-0.4(0.5) \mathrm{mm}$, whitish to finely speckled orange, the margins with long, delicate and usually twisted cilia 1/4-1/2 $x$ 
the scale length, cell texture hyaline with square to long hexagonal cells forming a grated texture. Segments (0.9)1.5-2.3 cm long and 2-2.5 mm wide, oblong to cylindrical, subchartaceous, the margins flat to narrowly revolute; adaxially glabrous; abaxially with parallel, thick and raised veinlets, these conspicuous despite being covered by scales; veinlet scales arachnoid, ca. 0.4 x $0.1 \mathrm{~mm}$; midvein scales dense, narrowly lanceolate to rectangular, apically fringed, 0.4-0.6(1) x 0.1-0.2 mm, whitish, the margins erose with long, twisted cilia 1/2-1 x the scale length, hyaline with rectangular to irregular cells. Sori inframedial, restricted to the segment center, nested within arachnoid scales, 8-16 pairs per segment, 3-4 sporangia per sorus. 


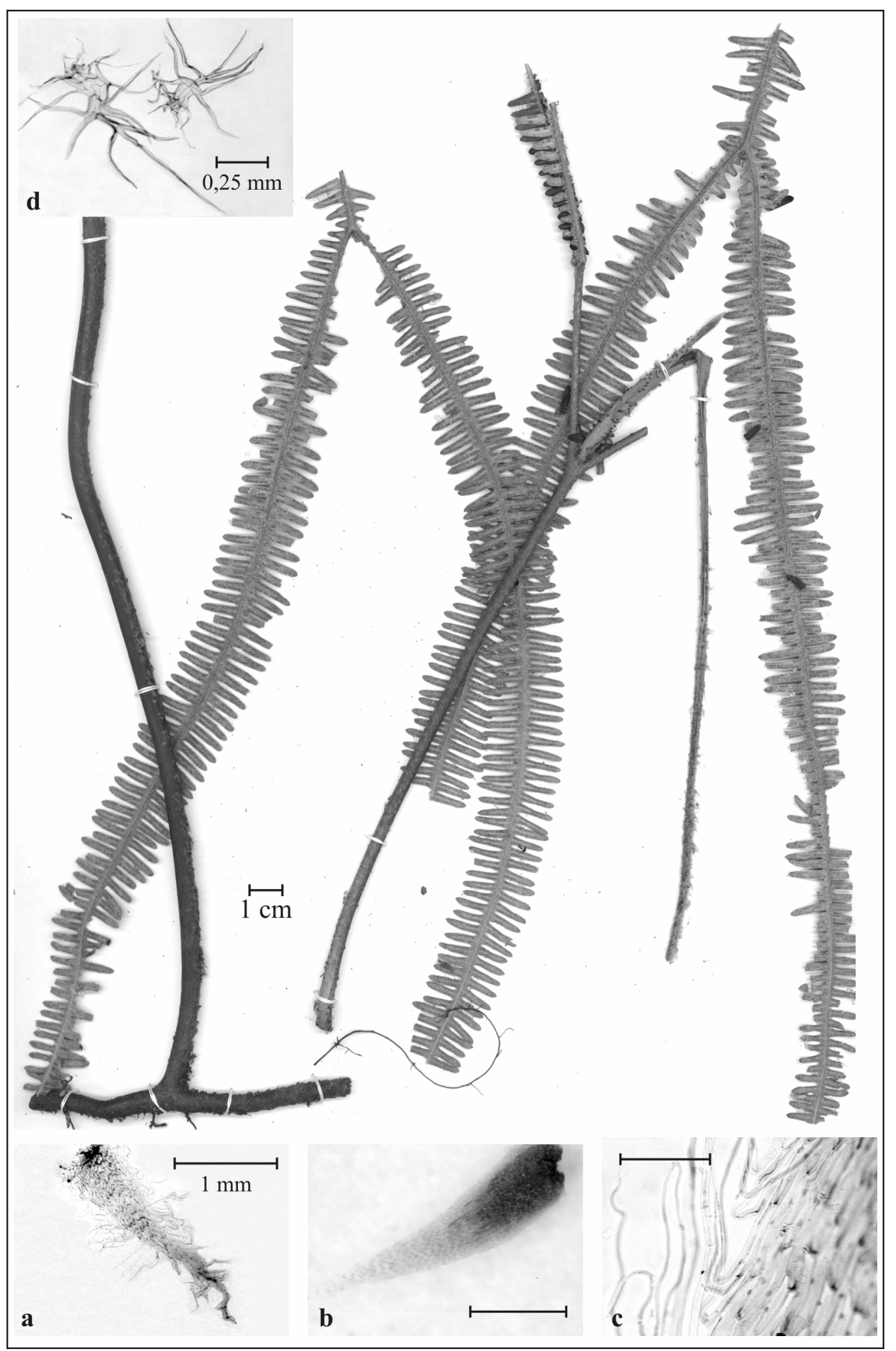

Fig. 16. Sticherus hispaniolensis J. Gonzales sp. nov., a) abaxial axis scales; b) bud scales; c) detail of the bud scale margin; d) midvein scales. Mickel 8748 (holotype, NY). 
Distribution and ecology. A common endemic to humid montane forest at 900-2800 $\mathrm{m}$ in the Dominican Republic and Haiti. Possibly also in Cuba.

Sticherus hispaniolensis is closely related to S. lanosus, but differs in having laxer, paler axis and midvein scales, narrower and shorter segments, more rounded cells of the axis scales, and less rigid scale margins with longer, delicate cilia (Tab. x). Sticherus hispaniolenis frequently has highly diverging segment lengths on axes of different order on the same plant, with long segments on the $1^{\text {st }}$ axis and shorter segments on the distal axes. In S. lanosus (and S. tomentosus) the segment length is more constant on a given plant. For practical purposes, both species cannot be confused because of their widely disjunct ranges.

Most specimens of $S$. hispaniolenis were formerly identified as $S$. ferrugineus because both species have aphlebiae and lax, hyaline midvein scales, but the relationship among these two species is probably not very close. Sticherus hispaniolensis is readily distinguished from $S$. ferrugineus by the much larger, basally partly rigid bud scales with shorter, more densely packed cells, thicker axes, shorter, more ovate segments, and abaxially parallel, thick, and raised veinlets. In most cases, both species can be recognized at a first glance by the relatively much longer 2nd axes (relative to the 1st axes) and shorter segments of S. hispaniolensis, which gives this species a different appearance.

A specimen from Cuba (Southern Oriente, Pico Tuquino, Jul 1922, León $11106, \mathrm{NY}$ ) resembles $S$. hispaniolensis but has a more reddish indument. More collections needed to evaluate its taxonomic position.

18. Sticherus blepharolepis (Sodiro) Ching, Sunyatsenia 5: 282. 1940

Gleichenia blepharolepis Sodiro, Recens. Crypt. Vasc. Quit. 5. 1883. Gleichenia pubescens var. blepharolepis (Sodiro) Sodiro, Anal. Univ. Centr. Ecuador 6 (47): 376. 1892. Type. Ecuador, Prov. Pichincha, "Canzacoto a las orillas del rio Yamboya", 1800 m, Sodiro s.n. (not found).

Plants large, robust. Rhizome 3.5-5 mm thick, dark brown, densely scaly, the scales falcate, lanceolate, acuminate, 3-4(6) x 1-1.4 mm, dark brown, the margins with regulary arranged setae, cell texture rigid with linear cells. Petiole 3-5 mm thick and 
$30 \mathrm{~cm}$ long, castaneous, rough, subpaleaceus. Rachis ca. 20-40 cm long between pinnae, the scales dark brown; aphlebiae large, trifoliate. Fiddlehead ca. $1.5 \mathrm{~cm}$ in diameter, densely scaly, the scales large, whitish to dusty orange. Bud large, ascending and opening rapidly, the scales lanceolate to ovate with rounded to cordate bases, (1.8)2-3(4) x 0.5-0.8 mm, gradually bicolorous with dark brown bases and whitish margins, the margins with numerous thin and slightly curled cilia $1 / 10 \mathrm{x}$ the scale length, cell texture stoutly-hyaline to gradually rigid, the cells hexagonal to linear, forming an opaque surface; the shape and size of the bud scales are quite consistent in a given plant. Pinnae $35-60 \mathrm{~cm}$ long, axes 3- to 4 -forked, $1^{\text {st }}$ axis 7-14 $\mathrm{cm}$ long and 2-3.5 mm thick, not pectinate; $2^{\text {nd }}$ axis $10-15 \mathrm{~cm}$ long and $1.5-3 \mathrm{~mm}$ thick, pectinate, $3^{\text {rd }}$ or distal axis linear-lanceolate, $30-50 \mathrm{~cm}$ long and $1-1.5 \mathrm{~mm}$ thick, deeply pinnatifid, 5-8 cm wide with segments, with 1.8 segments per cm; adaxial scales mixed, one type triangular, 0.4-0.6 x $0.1 \mathrm{~mm}$, the second type linear, hair-like, 3-5 x 0.01-0.1 mm, both scale types hyaline with dark orange parts formed by hardened cell walls, the cell rectangular to linear or irregular; lateral scales moderately dense to dense, mixed, one type square with a long, twisted apex, the second type lanceolate, 1-3 x 0.2-0.6 mm, brilliant orange; abaxial scales moderately dense to dense, mostly bicolorous, the margins straight with short, irregular cilia, the cells hexagonal to irregular and very narrow cells with thick walls projecting to the surface. Segments linear-oval, subchartaceous, all the proximal internal segments overlapping, the first proximal segment longer than the adjacent segment, (3)4-6 x 2$3.5 \mathrm{~mm}$, the margins chartaceous, ciliate; adaxially glabrous; abaxially with scales only on the midvein, the margins and around the sori; midvein scales triangular with an apical hair, ca. $0.2 \times$ ca. $0.1 \mathrm{~mm}$, ca. 4-7 irregular cell rows wide, brilliant orange to whitish, the margins with few, thick cilia $1 / 2-1 / 3 \times$ the scale length, hyaline; scales of the margins and around the sori arachnoid, orange-dusty. Sori medial, not reaching segment apex, densely nested within arachnoid scales, 13-24 pairs per segment, 4-5 sporangia per sorus.

Distribution and ecology. Endemic to the western Andean slope of Colombia (Chocó, Antioquia) and northern Ecuador (Pichincha) in humid montane forest at ca. $1700-2300 \mathrm{~m}$. 
Sticherus blepharolepis is typically characterized by lacking scales on the adaxial segment surface, except as scale nests around the sori, whitish to bicolorous, opaque, broadly lanceolate axis scales with shortly fringed apices, very long $1^{\text {st }}$ axes (to twice as long as the $2^{\text {nd }}$ ), densely scaly axes and rachises with bicolorous scales with hyaline margins and long, delicate cilia, and narrowly parallel, raised veinlets. The midvein scales are quite characteristic, being broadly lanceolate with a long apical hair or a long tuft of apical hairs. Sticherus blepharolepis is most similar to $S$. tomentosus in overall size, segment length and rachis scale density. However, $S$. blepharolepis has more highly divided leaves with longer axes, paler scales, more divided and shorter midvein scales, more deeply pinnatisect axes, and typically lacks scales abaxially on the segment surface.

Sticherus blepharolepis shows some confusing geographical variation in the density, coloration, and texture of the scales. In Ecuador, the segments are glabrous abaxially (except around the sori), the axis scales are whitish with an ill-defined cell texture, the midvein scales are hyaline, and the bud scales are lanceolate with erose margins (Østergaard \& Øllgaard, 2001). At the other extreme of the range, in Bolivia, the segments are scatteredly scaly abaxially, the axis scales are bicolorous with rigid, dark apices, the midvein scales are rigid with dark cilia, and the bud scales are broadly lanceolate with long-ciliate margins. Both forms have narrow marginal scales that give the impression of cilia, but in Ecuadorean material these are much more conspicuous because they contrast with the glabrous lamina surface, while in Bolivian specimens similar scales are also found on the veinlets. These differences would appear to suggest that both populations should be considered to be taxonomically distinct. However, all differences are fairly variable within the populations and it is quite possible that some of it can be attributed to hybridization with other species. Thus the Ecuadorean material partly approach more $S$. melanoblastus, while in Bolivia, some specimens resemble S. lanosus. Until the morphological and geographical variability and it underlying causes are better understood, it seems best to treat all specimens as one variable species.

The type specimen of S. blepharolepis has not been located and I follow the concept of Østergaard \& Øllgaard (2001) who studied material assigned by Sodiro to this species. 
19. Sticherus jacha J. Gonzales sp. nov

Type. Bolivia, La Paz, Prov. Nor Yungas, 5 km Chuspipata hacia Coroico, $16^{\circ} 23^{\prime} \mathrm{S}$, 67²8'W, 2750 m, 18 Sep 1997, Kessler et al. 11971 (holotype, UC; isotypes, LPB, GOET).

Affinis S. blepharolepidi, sed differt segmentis laminae angustioribus, linearibus, margine leviter revolutis in pagina abaxiali sparse squamatis. Rhachis primaria usque ad duplus longitudinis rachidis secondariae, remote pectinata, in pagina abaxiali dense squamata et squamis bicoloribus (non albidis).

Plants medium-sized to large, robust. Rhizome unknown. Petiole 3-5 mm thick, over $30 \mathrm{~cm}$ long, castaneous, subpaleaceous. Rachis ca. 20-40 cm long between pinnae, densely scaly, the scales usually bicolorous, brown with whitish margins; aphlebiae trifoliate with narrow, long segments. Fiddlehead $1-1.5 \mathrm{~cm}$ in diameter, densely scaly, bicolorous whitish to pale orange with dark brown rows. Bud large, ascending, closed, the scales lanceolate with rounded bases, 1.4-3.2 x 0.5-1.2 mm, the margins with numerous thin, straight to slightly curled cilia $1 / 4-1 / 8 \times$ the scale length, cell texture mixed, basally rigid and sometimes with scattered darkened apical cells to opaque with hyaline margins, cells rectangular, bicolorous with whitish margins and dark centers of varying extent; the youngest bud scales are usually more hyaline. Pinnae 35-60 cm long, 3- to 4-forked, $1^{\text {st }}$ axis longer than the $2^{\text {nd }}, 10-25 \mathrm{~cm}$ long and 2-3 mm thick, when pectinate only with internal, long, remotely pinnatisect segments, $2^{\text {nd }}$ axis $8-12 \mathrm{~cm}$ long and $1.5-3 \mathrm{~mm}$ thick, usually fully pectinate with remote segments, $3^{\text {rd }}$ or distal axis $10-30 \mathrm{~cm}$ long and $1 \mathrm{~mm}$ thick, pinnatisect, both axes 5-6 cm wide with segments, $4^{\text {th }}$ and last axis lanceolate, apically gradually decreasing to a conform apex, 15-25 cm long, deeply pinnatifid, with 1.5-2.5 segments per cm, proximal segments gradually reduced and overlapping internally; adaxially with mixed scales, one type linear, 1-2.5 x 0.1-0.05 mm, the margins with short cilia, the second type rectangular, 0.2-0.6 x 0.1-0.2 mm, the margins with cilia $1 / 2-1 \times$ the scale length, both scale types pale orange to whitish, cell texture hyaline with rigid parts formed by some hardened cell walls, the cells rectangular to irregular; abaxially and laterally densely scaly, the scales lanceolate, (1)2-4 x (0.2)0.6-1 mm, usually pale orange on last and bicolorous on $1^{\text {st }}$ axes, the margins 
with delicate cilia, cell texture hyaline with rectangular cells, sometimes with darkened cells at the bases and/or the apices. Segments linear, 1.8-3.2 x 0.4-0.2 mm, the margins chartaceous, revolute; adaxially glabrous; abaxially densely scaly on midvein and veinlets; midvein scales mixed, one type linear to hair-like, 1-3.2 x ca. $0.5 \mathrm{~mm}$, the second type rectangular, 0.2-0.6 $\times 0.1-0.2 \mathrm{~mm}$, both scale types whitish to orange or speckled, the margins with usually curled cilia $1 / 2-1 \times$ the scale length, cell texture hyaline with linear to irregular cells; veinlets angular, raised, scatteredly scaly, the scales coarsely star-shaped,ca. $0.2-0.3 \mathrm{~mm}$ in diameter, marginally ciliate. Sori medial, not reaching segment apex, nested within arachnoid scales, 13-24 pairs per segment, 4-5 sporangia per sorus. 


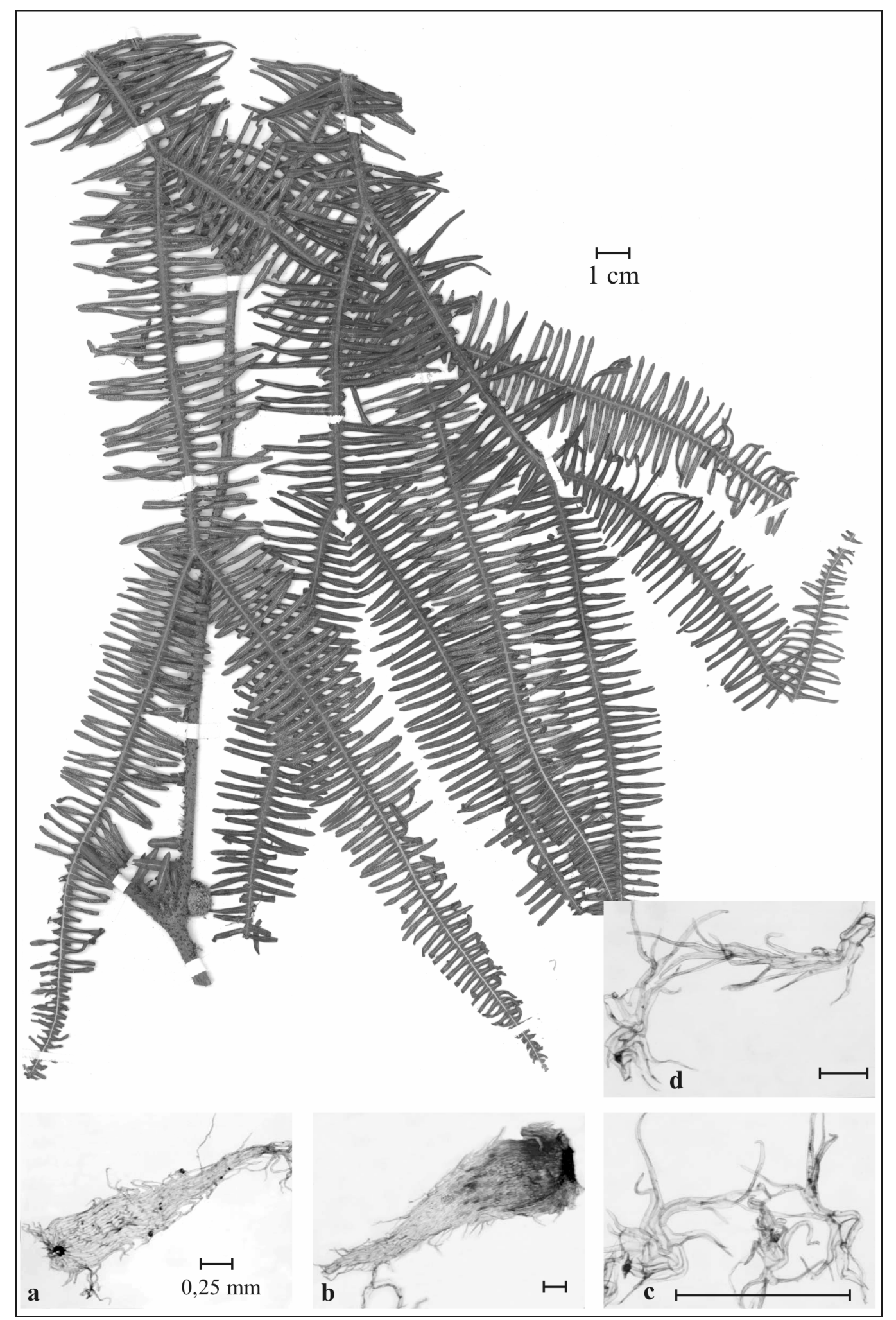

Fig. 17. Sticherus jacha J. Gonzales sp. nov., a) bud scales; b) midvein sclaes; c) and d) scales on the abaxial segment surface. Kessler et al. 11971 (holotype, UC). 
Distribution and ecology. Endemic to humid montane forest at $1900-2750 \mathrm{~m}$ in Bolivia (La Paz, Cochabamba). Locally common along roadsides and on landslides.

Sticherus jacha is characterized by the densely scaly rachises and axes with bicolorous scales, the long 1 st axes that may be up to twice as long as the $2^{\text {nd }}$, and the last pectinate axes that are narrower than the previous. The proximal bud scales are bicolorous with dark, rigid bases and whitish, hyaline margins and apices. Sticherus jacha is most similar to $S$. blepharolepis but differs in having narrower, more linear, marginally slightly revolute; abaxially sparsely scaly segments, remote to pectinate (vs. deeply pinnatifid) proximal axes, and denser, bicolorous (vs. whitish) scales on the abaxial axes. Both species have fine, raised veinlets, but in $S$. jacha these are placed at a steeper angle to the midvein. The scales on the midvein and veinlets in $S$. jacha are crumpled and reminiscent of the scales of S. peruvianus.

Superficially, $S$. jacha also resembles $S$. melanoblastus, but $S$. jacha is a more robust plant with conspicuous aphlebiae and larger scales. The scale hardening in $S$. jacha proceeds from the base of the scales as in S. tomentosus, whereas in $S$. melanoblastus it starts at the scale center and proceeds towards the apex and margin and usually leaves the bases hyaline. Sticherus jacha and S. blepharolepis always have hyaline margins with delicate cilia, while in $S$. melanoblastus the margins have thick, short setae.

The name "jacha" is the word for "large" in the high-Andean Aymara language that is spoken in the range of this species.

20. Sticherus velatus (Kunze) Copel., Ann. Cryptog. Phytopatol. 5: 28. 1947.

Mertensia velata Kunze, Linnaea 9:15. 1834. Gleichenia velata (Kunze) Mett., Fil. Hort. Bot. Lips. 113. 1856. Dicranopteris velata (Kunze) Maxon, Contr. U.S. Natl. Herb. 24: 50. 1922. Type. Peru, Huanuco, Pampayacu, Jul 1829, Poeppig s.n. (holotype, W; the fragment of Poeppig s.n. at US annotated as isotype of S. velatus is in fact S. lanosus).

Plants medium-sized to large. Rhizome 5-7 mm thick, lustrous, dark brown, the scales somewhat deciduous, falcate, oblong to lanceolate, acuminate with 2 apical setae, $2.8-4.5 \times 0.6-1 \mathrm{~mm}$, brown, the margins with short, regularly arranged setae, 
cell texture fine, rigid with rectangular cells. Petiole $30-60 \mathrm{~cm}$ long and 4-4.5 mm thick, light-castaneous to stramineus, subpaleaceus. Rachis ca.35 cm long between pinnae, the scales large, whitish; aphlebiae trifoliate to pinnatifid. Fiddlehead 4-7 $\mathrm{mm}$ in diameter, matted, the scales dense, white to yellow. Buds of proximal axes large and of distal axes shorter, ascending, semi-open, the scales narrowly lanceolate, basally truncate, apically fringed and/or long-ciliate, (1.5)3-4(6.5) x 0.4-0.8(1.4) mm, bicolorous with orange bases and centers and whitish margins, the margins with straight, regularly arranged cilia $1 / 5-1 / 3 \times$ the scale length, cell texture grated with short, narrowly hexagonal cells and linear marginal cells. Pinnae 30-60 cm long, axes 3- to 4-forked, $1^{\text {st }}$ and $2^{\text {nd }}$ axes shorter than the distal ones, (5)6-15 cm long and 2-3.5 $\mathrm{mm}$ thick, both axes with trifoliate aphlebiae, the $1^{\text {st }}$ axis not pectinate, $2^{\text {nd }}$ axis pectinate, ca. $4 \mathrm{~cm}$ wide with segments, the internal segments gradually reduced, $3^{\text {rd }}$ axis $18-34 \mathrm{~cm}$ long and $1.5-2 \mathrm{~mm}$ thick, $4.5-5 \mathrm{~cm}$ wide with segments, $4^{\text {th }}$ axis ca. 20 $\mathrm{cm}$ long and ca. $1.5 \mathrm{~mm}$ thick, lanceolate, $3-3.5 \mathrm{~cm}$ wide with segments, with ca. 2.5 segment per $\mathrm{cm}$, each opposite pair of axes unequal in size; adaxial scales mixed, one type linear, $2.5-5 \times 0.8-1.2 \mathrm{~mm}$, hyaline to light orange, the second type rectangular, 0.4-0.5 x $0.05 \mathrm{~mm}$, both scale types with rectangular-linear or irregular cells; abaxial and lateral scales lanceolate, narrow, apically with 3 long cilia, a tuft of cilia, or with the middle cilium prolonged to a pectinate hair, 0.6-1.6(3) x 0.2-0.3(0.5) $\mathrm{mm}$, about 7 cell rows wide, whitish to dull hyaline, the margins with long, curved cilia 1/3-1/2 $\mathrm{x}$ the scale length, cell texture homogeneously grated with hexagonal cells. Segments linear to oval, chartaceous, (1.4)1.8-2.4 x 2.5-3(3.5) $\mathrm{mm}$, the margins slightly revolute, ciliate; abaxial scales only on the veins, covering $15-60 \%$ of the leaf surface; midvein scales fimbriate, hyaline to light orange, mixed, one type linear, 2.5-3.2 $\times 0.1 \mathrm{~mm}, 2$ cell rows wide, the margins with a few cilia about $1 / 3 \times$ the scale length, the cells rectangular, very large, the second type rectangular, sometimes with a pectinate apical hair up to $2.4 \mathrm{~mm}$ long, $0.5-0.8 \times 0.3 \mathrm{~mm}, 3$ to 4 cell rows wide, the cells elongate, rectangular, each bearing a marginal cilium, the third type reduced, fimbriate, ca. $0.5 \times 0.1 \mathrm{~mm}, 2-4$ cell rows wide, the margins with wavy cilia 3-4 x the scale length; abaxial scales restricted to the secondary veins, scattered, covering about $40 \%$ of the surface, arachnoid, 0.05-0.3 $\mathrm{mm}$ in diameter; adaxially glabrous or with a few fimbriate scales similar to, but paler than, those on the midvein. Sori medial, nested superficial within arachnoid scales, 9-16 pairs per segment, 3-5 sporangia per sorus. 
Distribution and ecology. Disjunct on the Guyanan Shield of southeastern Venezuela, the Andes of Peru and Bolivia, and in southeastern Brazil. In montane forests, clearings, and along roadsides at $1500-2400 \mathrm{~m}$, down to $900 \mathrm{~m}$ in Brazil.

Sticherus velatus is readily recognized by its fibrillose midveins scales, and is further characterized by its rather sparse abaxial indument, broad, pale, entire rhizome scales, and its rather pale axis scales with thin, long, contorted marginal cilia. Sticherus velatus is most similar to S. lanosus in the leaf arquitecture and size, but that species has much broader midvein scales and a thicker lamina texture. Sticherus velatus has long been considered to be synonymous with $S$. tomentosus but differs in its shorter scales, shorter segments, more highly divided leaves, and paler scales (Tab. x). Sticherus velatus may also be confused with $S$. squamosus but that species has dark orange, more rigid scales, narrower axis and bud scales, and is almost glabrous abaxially on the lamina surface. These two species, and $S$. lanuginosus, all have rather similar, broadly lanceolate, golden-brown, entire rhizome scales, that are strikingly different from the narrowly lanceolate, dark reddish brown, ciliate rhizome scales of $S$. tomentosus and its allies. Whether this similarity in the rhizome scales among $S$. velatus, $S$. squamosus, and S. lanuginosus is indicative of a close relationship among these species is unclear.

21. Sticherus squamosus (Fée) J. Gonzales comb. nov.

Mertensia squamosa Fée, Crypt. Vasc. Bresil, p. 232, t. 72, f. 2. Type. Brasil, Minas Gerais, 8 Apr 1868, Glaziou 2279 (holotype, P).

Gleichenia paulistana Rosenst., Repert. Nov. Sp. Fedde 21: 343. 1925. Sticherus paulistanus (Rosenst.) Copel., Ann. Cryptog. Phytopatol. 5: 28. 1947. Type. Brazil, São Paulo, Serra do Mar, 26 Apr 1914. Brade 6924 (holotype, S; isotype, US).

Plants medium-sized, semirobust. Rhizome 5-9 mm thick, dark brown, the scales deciduous, lanceolate, basally truncate, 3-5.5 x 0.5-0.8 mm, orange, the margins with somewhat irregularly arranged setae, cell texture grated with linear cells. Petiole 30$50 \mathrm{~cm}$ long and 4-7 mm thick, castaneous to stramineus. Rachis $\mathrm{ca} .20-40 \mathrm{~cm}$ long 
between pinnae, subpaleaceus, the scales dusty orange; aphlebiae trifoliate with narrow, long segments. Fiddlehead ca. 3-5 mm in diameter, moderately scaly, the scales dark orange to cinnamon. Bud ascending and opening rapidly, the scales narrowly lanceolate, acuminate with long-ciliate and/or fringed apices, (1.4)2-3.2 x $0.2-0.5 \mathrm{~mm}$, orange, the margins with slightly curled cilia $1 / 10 \mathrm{x}$ the scale length, cell texture semirigid with hexagonal cells, forming an opaque surface; the shape and size of the bud scales are quite consistent in a given plant. Pinnae $25-50 \mathrm{~cm}$ long, $4-$ to 6forked, $1^{\text {st }}$ axis 3-8 $\mathrm{cm}$ long and 2-3 $\mathrm{mm}$ thick, only with scattered proximal internal segments adjacent to the aphlebiae, $2^{\text {nd }}$ axis $7-10 \mathrm{~cm}$ long and $1.5-2 \mathrm{~mm}$ thick, pectinate, $4-5.5 \mathrm{~cm}$ wide with segments, with 2 segments per $\mathrm{cm}, 3^{\text {rd }}$ axis $12-25 \mathrm{~cm}$ long and 1-2 mm thick, pectinate, $3-5 \mathrm{~cm}$ wide with segments, $4^{\text {th }}$ and $5^{\text {th }}$ axes shorter and narrower than the previous, $5-20 \mathrm{~cm}$ long and $0.5-1 \mathrm{~mm}$ thick, $2-3 \mathrm{~cm}$ wide with segments; the scales adaxially mixed, one type rectangular, 0.4-0.5 x 0.05$0.1 \mathrm{~mm}$, the second type linear to hair-like, 2-3 x 0.01-0.1 mm, both scale types (1)23 cells wide, hyaline, cell texture rectangular-linear or irregular, the margins with few straight, spreading cilia $1 / 2 \mathrm{x}$ the scale length; abaxially and laterally moderately scaly, the scales linear-lanceolate, apically fringed or with along hair, 1-2 x 0.2-0.4 $\mathrm{mm}$, whitish orange, the margins with straight cilia $1 / 4 \times$ the scale length, cell texture grated, opaque, with long, irregular cells. Segments linear, the proximal ones usually of irregular length, internal segment overlapping or not, 5-22 x 2-3 mm, the margins ciliate, revolute; adaxially glabrous; abaxially densely scaly on the midvein, the scales fimbriate, usually with two longer apical cilia, $0.4-0.8 \times 0.1 \mathrm{~mm}$, orangedusty, the margins with a few cilia 1/2-1 $\mathrm{x}$ the scale length, with rectangular to irregular cells; veinlets with a few fimbriate scales; Sori inframedial, not reaching segment apex, nested within a few fimbriate scales, ca. 13 pairs per segment, 3-4 sporangia per sorus.

Distribution and ecology. Endemic to southeastern Brazil (Minas Gerais, Sao Paulo, Paraná, Santa Catarina). Locally common in humid forest from sea level to $600 \mathrm{~m}$.

Sticherus squamosus is characterized by the fibrillose, strongly orange-dusty midvein scales, simple, fibrillose veinlet scales, very narrow, linear axis scales with a single apical hair, large, narrow, trimerous aphlebiae, and 3- to 5-forked pinnae with axes of roughly similar length (except for the longer ultimate axis). Specimens of $S$. 
squamosus in herbaria have mostly been identified as $S$. lanuginosus, probably in part because both species have similar, thick rhizomes with dense, large, entire scales. However, S. squamosus has more strongly hardened midvein scales, shorter and straighter marginal cilia on the axis scales, longer axes and segments, and more widely diverging axes than $S$. lanuginosus. Sticherus squamosus is probably most closely related to $S$. velatus as evidenced by the fibrillose midvein scales and the overall similarity in size and arquitecture, but Sticherus velatus differs in having much broader, lanceolate, bicolorous bud scales, and paler, laxer, and larger axis and midvein scales. Given their similarity, it is conceivable that $S$. squamosus evolved from a marginal population of more widespread S. velatus.

22. Sticherus lanuginosus (Fée) Nakai, Bull. Natl. Sci. Mus. 29: 20. 1950.

Gleichenia lanuginosa Moric. ex Fée, Crypt. Vasc. Brésil 1: 202. 1869. Gleichenia pennigera var. lanuginosa (Moric. ex Fée) Moore, Index Fil. 20: 381. 1862. Type. Brazil, Bahía, Blanchet \& Claussen 88 (isotype, US).

Plants small to medium-sized, robust. Rhizome (3.5)4-5(6.5) mm thick, dark brown, the scales deciduous, lanceolate, (1.5)2-3.6(5) x 0.4-0.8(1) mm, dark brown, the margins with inconspicuous cilia, cell texture semirigid, with hexagonal to linear illdefined cells. Petiole ca. $50 \mathrm{~cm}$ long and (2)3-4(7.5) mm thick, light castaneus to stramineus, subpaleaceus. Rachis ca. $25-50 \mathrm{~cm}$ long between pinnae, subpaleaceus, the scales usually whitish to slightly bicolorous with dark orange bases; aphlebiae trifoliate. Fiddlehead ca. $0.5 \mathrm{~cm}$ in diameter, densely scaly, the scales whitish. Bud ascending and opening rapidly, the scales narrowly lanceolate to linear, basally rounded, apically acuminate, with long cilia and/or fringed, (1)1.2-2.6(4) x 0.3-0.8 $\mathrm{mm}$, whitish to orange, the margins hyaline with numerous delicate and slightly curled cilia 1/4-1/6 x the scale length, cell texture hyaline to lax-hyaline, the cells usually ill-defined, hexagonal; shape and size of the bud scales are quite consistent in a given plant. Pinnae 5-20 cm long, axes (3)4- to 5-forked, forming very close angles, $1^{\text {st }}$ axis $1.5-2.5(4) \mathrm{cm}$ long and $1.5-3 \mathrm{~mm}$ thick, shorter than the $3^{\text {rd }}$ and $4^{\text {th }}$, not pectinate, with conspicuous aphlebiae, $2^{\text {nd }}$ axis $1-2.5(4) \mathrm{cm}$ long and $1.5-3 \mathrm{~mm}$ thick, shorter than the $3^{\text {rd }}$ and $4^{\text {th }}$, occasionally with internal proximal segments adjacent to the aphlebiae, $3^{\text {rd }}$ and $4^{\text {th }}$ axes the longest, (3)4-7(12) $\mathrm{cm}$ long and 0.4-1 
mm thick, pectinate, $1.2-2(3) \mathrm{cm}$ wide with segments, with ca. 3 segments per $\mathrm{cm}, 5^{\text {th }}$ axis usually narrower than the previous, (6)8-10 cm long and 0.4-0.5 mm thick, pectinate, 1-1.5 cm wide with segments, with 3-4 segments per $\mathrm{cm}$; adaxially the scales mixed, one type fimbriate, broadly rectangular, sometimes with an apical hair 1-2 mm long (specially on Brazilians specimens), 0.1-0.8 x 0.05-0.1 mm, the second type hair-like, $1-3.5 \times 0.02-0.2 \mathrm{~mm}$, both scale types hyaline, orange, the margins with irregularly arranged, scattered cilia $1 / 5-1 \mathrm{x}$ the scale length, cell texture rectangular-linear or irregular; abaxially and laterally moderately to densely scaly, the scales linear-lanceolate ith a long apical hair and/or a fringed, the scales mixed, one type apically fringed or with a hair 0.4-1 mm long, 0.2-0.8 x 0.1-0.2 $\mathrm{mm}$, the second type with an apical hair 0.6-1.5 mm long, (1)2-4 x 0.2-0.4 mm, both scale types whitish to orange, the margins with curved cilia 1/4-1 x the scale length, cell texture grated with narrow cells. Segments linear to oval, subchartaceous, (1.5)4$7(14) \times 1.5-2.2 \mathrm{~mm}$, proximal internal segments gradually slightly overlapping, the margins chartaceous, revolute, ciliate; adaxially glabrous; abaxially densely to scatteredly scaly on veinlets, surface, and margin, the scales mixed, one type shortfibrillose, $0.2-0.8 \times 0.05-0.1 \mathrm{~mm}$, the other type long-fibrillose, 2-4 x 0.01-0.05 mm, both scales types with the margins with cilia 1/7-1/2 x the scale length. Sori inframedial, usually restricted to the middle of the segment, not nested within scales, 3-7 pairs per segment, 3-5 sporangia per sorus.

Distribution and ecology. Hispaniola, Venezuela, Colombia, Ecuador, Peru, Bolivia, eastern and central Brazil, and adjacent Paraguay. Often common in montane pastures and savannas, specially in burnt habitats. At 1000-1250 m on Hispaniola, 800-3000 m in the Andes, and 700-1650 m in Brazil and Paraguay.

Sticherus lanuginosus is a familiar species that has long been known under the name of $S$. penniger, but close examination of the holotype of $S$. penniger at $\mathrm{M}$ has convinced me that it represents the same species as $S$. pruinosus. This confusion has probably arisen because pteridologists working on this species have usually only seen the photographs at US of the type collections of $S$. penniger. These photographs shows plants of a habit roughly similar to S. lanuginosus, but they do not allow a study of the diagnostic scale characters, which clearly show that the type material of $S$. penniger belongs to $S$. pruinosus. To complicate things even further, Sturm (1840) 
and Sehnem (1970) used the name Gleichenia pubescens Humb. \& Bonpl. ex Willd. for $S$. lanuginosus. However, the name G. pubescens was misapplied, because it is a synonym of S. bifidus. Sturm (1840) and Sehnem (1970) used the name S. penniger for a taxon distinct from $S$. pruinosus, but in my view the characters they use for distinguishing these two species are not consistent, and I believe it is best to combine them under the name S. pruinosus (which see for further discussion).

Sticherus lanuginosus is characterized by the very narrow angle between diverging axes and short $1^{\text {st }}$ to $2^{\text {nd }}\left(3^{\text {rd }}\right)$ axes, resulting in the pinnae held conspicuously upwards. It further is 4 - to 5-forked, has fimbriate, hyaline bud and axis scales, and fibrillose midvein scales. Sticherus lanuginosus may be confused with $S$. velatus, but that species has longer and more spreading axes, larger segments, and larger and broader midvein scales. These two species, and S. squamosus, all have conspicuously similar rhizomes. These are thick and bear large, broadly lanceolate, dark orange, and entire scales. Sticherus pruinosus, with which S. lanuginosus has been confused in the past (see above), differs in having more slender rhizomes with narrowly lanceolate, dark, setose scales, being shorter overall, and in its shorter, more rounded to triangular segments.

Sticherus lanuginosus varies considerably in size, presumably in response to habitat conditions. Specimens from dry and sunny (and also perhaps from nutrientpoor) sites are shorter, with more closely held axes, and have more coriaceous segments with more strongly revolute margins. In addition, there appears to be a geographical component to the size variation, with specimens from Venezuela and southeastern Brazil being on average somewhat larger than those from the central Andes. This may perhaps be partly due to hybridisation with other species, e.g., with S. velatus in Brazil.

One collection from Peru (San Martín, Zepelacio near Moyobamba, 1200$1600 \mathrm{~m}$, Klug 3458, MO, US), has filamentous, contorted, dark orange midvein and veinlet scales that contrast with the matted, pale orange to whitish axis and bud scales. This scale pattern is reminiscent of S. lanuginosus and S. velatus. However, the proximal axes are long and the overall architecture is similar to S. jacha, but with all axes remotely pinnatisect and linear segments. It was identified as $S$. lanosus by Morton in 1968 and as S. bifidus by Stolze in 1986, but is neither of these species. This collection thus does not correspond to any of the species recognized here. The spores appear to be normal and the specimen does not show the typical characters of 
hybrids (unequal axes, irregular scales, hybrid vigour). Its taxonomic placement must await further collections.

23. Sticherus compactus (H. Christ) Nakai, Bull. Nation. Sc. Mus. Tokyo 29 : 15. 1950.

Gleichenia compacta H. Christ, Bull. Boiss. II 5:254. 1905. Type. Costa Rica, La Palma, Werckle s.n. (holotype, BAS).

Gleichenia mellifera H. Christ, Bull. Boiss. II 6: 281, 1906. Sticherus mellifer (H. Christ) Nakai, Bull. Nation. Sc. Mus. Tokyo 29: 15. 1950. Type. Costa Rica, Rio Navarro, 1400 m, Werckle s.n. (holotype, P).

Gleichenia bradeorum Rosenst., Rep. Sp. Fedde 10: 274. 1912. Type. Costa Rica, La Palma, C. Brade 501 (holotype, BM).

Plants large, robust. Rhizome 4-6 mm thick, dark brown, moderately to densely scaly, the scales falcate, lanceolate, long acuminate, 4.5-5.5 x 1-1.5 mm, golden-brown, the margins with thin, regularly arranged setae, cell texture semirigid with linear cells. Petiole over $50 \mathrm{~cm}$ long and 5-8 mm thick, castaneous, subpaleaceus. Rachis ca. 35$45 \mathrm{~cm}$ long between pinnae, subpaleaceus, the scales brown; aphlebiae trifoliate with narrow, long segments. Fiddlehead ca. $0.5-10 \mathrm{~mm}$ in diameter, moderately scaly, the scales large, bicolorous dusty orange with dark brown streaks. Bud slender, ascending and opening rapidly, the scales lanceolate, narrowly acuminate, (0.8)1.5$3(5) \times(0.1) 0.5-1.2 \mathrm{~mm}$, usually bicolorous with the golden-orange centers and dark brown margins, the margins with numerous setae or straight cilia $1 / 10 \mathrm{x}$ the scale length, cell texture stoutly hyaline, rigid along the scale margins, cells rectangular to linear. Pinnae 50-70 cm long, 3- to 4-forked; $1^{\text {st }}$ axis 8-15 cm long and 3.5-4 mm thick, usually longer than the $2^{\text {nd }}$, not pectinate, $2^{\text {nd }}$ axis $5-15 \mathrm{~cm}$ long and $2-3 \mathrm{~mm}$ thick, not pectinate, $3^{\text {rd }}$ axis $5-15 \mathrm{~cm}$ long, $4^{\text {th }}$ or distal axis lanceolate, $20-30 \mathrm{~cm}$ long and 1-2 mm thick, both last axes pinnatisect, 3-4 cm wide with segments, with 2-2.5 segments per cm; scales adaxially mixed, one type star-shaped, $0.5 \times 0.1 \mathrm{~mm}$, the second type linear to hair-like, ca. 4 x $0.1 \mathrm{~mm}$, both scale types hyaline to semirigid, the margins with few cilia; abaxially and laterally moderately scaly, the scales 
narrowly lanceolate, usually long acuminate, always with 2 unequal apical setae, (0.6)1-3(5) x 0.2-0.5 mm, basally ca. 8 cells rows wide, the lateral scales larger than those on the surface, bicolorous golden-orange to brown, the margins usually with a mixture of cilia and setae $1 / 10 \mathrm{x}$ the scale length, cell texture usually mixed, hyaline on the scale centers, marginally rigid, the cells square. Segments $1.5-3 \mathrm{~cm}$ long and 2.5-4 mm wide, cylindrical, pinnatisect, herbaceous, all the proximal internal segments overlapping, the margins chartaceous, ciliate; adaxially glabrous; abaxially sparsely scaly; midvein scales mixed, one type rectangular to triangular, 0.3-0.5 x 0.05-0.1 mm, the second type long-linear, 2-5 x 2-3 cell rows, both scale types orange and sometimes with dark brown margins, the margins with a few cilia or setae $1 / 2-1 \times$ the scale length, cell texture mixed hyaline with rigid margins; veinlets parallel, slightly raised, scaly, the scales short, star-shaped, orange to whitish, lax hyaline, the margins with a few cilia. Sori medial to inframedial, not reaching the tip of the segment, not nested in scales, 14-19 pairs per segment, 3-5 sporangia per sorus.

Distribution and ecology. Mountains of Costa Rica and Panama. In open habitats in humid montane forest at $850-1600 \mathrm{~m}$.

Sticherus compactus is very similar to $S$. furcatus and the specimens in many herbaria are misidentified. The main difference between them is that in S. compactus the axis and bud scales are hardened from the margins, while in S. furcatus the hardening is basal. Further differences are detailed under the latter species. $S$. compactus may also be confused with $S$. rubiginosus which also has marginally hardened scales, but $S$. rubiginosus has larger, long-lanceolate axis and bud scales, is shorter overall, and has narrwoly linear midvein scales. Sticherus compactus is often easily recognized in adult specimens by the blackish bud and rachis scales. It is perhaps the largest Neotropical species of the genus, with petioles of up $8 \mathrm{~mm}$ thick.

24. Sticherus furcatus (L.) Ching, Sunyastenia 5: 283. 1940.

Acrostichum furcatus L., Syst. Nat. ed. x. 2. 1321.1. 1759. Mertensia furcata (L.)

Willd., Kongl. Vatensk. Acad. Nya handl. 166. 1804. Gleichenia furcata (L.)

Spreng., Syst. 4: 26. 1827. Type. PlumierTab. 28. 
Mertensia palmata W. Schaffn. ex E. Fourn., Mem. Foug. 9: 40. 1857. Gleichenia palmata (W. Schaffn. ex E. Fourn) Moore, Ind. Fil.: 380. 1862. Dicranopteris palmata W. Schaffn. ex E. Fourn., Bull. Torrey Bot. Club 34: 259. 1907. Sticherus palmatus (W. Schaffn. ex E. Fourn.) Copel. Gen. Fil. (Ann. Cryptog. Phytopatol. 5:) 28. 1947. Type. Mexico, 1857, Schaffner s.n. (Morton Neg. No. 4529) (holotype, P; photo, US).

Plants medium-sized, semirobust. Rhizome 4-5 mm thick, dark brown, rough, densely scaly, the scales falcate, lanceolate with auriculate bases, 2.5-5.5 x 1-1.5 $\mathrm{mm}$, golden-orange, the margins shortly setose, cell texture semirigid with short, linear cells. Petiole over $30 \mathrm{~cm}$ long and 3-7 mm thick, castaneous, subpaleaceus. Rachis ca. 20-30 cm long between pinnae, densely scaly, the scales dark orange; aphlebiae trifoliate with narrow, long segments. Fiddlehead ca. $10 \mathrm{~mm}$ in diameter, densely scaly, the scales large, membranaceous, dusty orange. Bud large, ascending and relatively closed, the scales lanceolate, basally truncate, (1.5)2-3(5) x 0.5-1 mm, gradually bicolorous, dusty orange in the center with whitish margins, the margins with numerous, straight and thick cilia $1 / 5-1 / 10 \times$ the scale length, cell texture stoutly hyaline with short, rectangular, sometimes ill-defined cells. Pinnae 30-40(50) cm long, 4- to 5-forked, $1^{\text {st }}$ axis sometimes longer than the $2^{\text {nd }}, 3.5-7 \mathrm{~cm}$ long and $1.5-3.5$ $\mathrm{mm}$ thick, not pectinate, $2^{\text {nd }}$ axis $2.5-6.5 \mathrm{~cm}$ long and $1-2.5 \mathrm{~mm}$ thick, occasionally with scattered proximal internal segments, $3^{\text {rd }}$ axis $4-20 \mathrm{~cm}$ long and $1-2 \mathrm{~mm}$ thick, pectinate but lacking proximal internal segments on the first $0.5-1.5 \mathrm{~cm}, 3.5-4.5 \mathrm{~mm}$ wide with segments, $4^{\text {th }}$ and usually distal axis (7)20-30 $\mathrm{cm}$ long and (0.5)1.5-2 mm thick, lanceolate, distally deeply pinnatifid, (2)3.5-5 cm wide with segments, with ca 2.5 segments per cm, proximal internal segments overlapping; adaxial scales linear lanceolate to lanceolate with truncate bases, 1.7-2.7(4) x 0.1-0.2 mm, orange to whitish, the margins with cilia ca. 1/8 x the scale length, cell texture stoutly hyaline; abaxial moderately to densely scaly, the scales lanceolate, basally truncate, apically glandular or with a long, twisted hair, (0.5)1-2.6(3) x (0.1)0.3-0.7 mm, bases ca. 5 cell rows wide, orange, the margins with numerous and straight cilia 1/4-1/2 $\mathrm{x}$ the scale length, cell texture stoutly hyaline with short, rectangular cells. Segments 1-2.5 cm long and (1.5)2-3.5 mm wide, cylindrical, herbaceous, pinnatisect to slightly remote, the margins ciliate, slightly revolute; adaxially glabrous; abaxially scaly on 
midvein and veinlets; midvein scales fibrillar to star-shaped, (0.06)0.2-1(2) x 0.01$0.06 \mathrm{~mm}$, pale orange to whitish, the margins with few, thick cilia 1/3-3 x the scale length, hyaline; veinlets slightly raised, sparsely covered with star-shaped to hair-like scales, whitish and hyaline. Sori medial to inframedial, not reaching the tip of segments, not nested in scales, 17-21 pairs per segment, 3-6 sporangia per sorus.

Distribution and ecology. Mountains in Mexico, Guatemala, Belize, Honduras, El Salvador, Nicaragua, Costa Rica, Cuba, Jamaica, Guadaloupe, and northern Venezuela. Wet montane forest at $800-2400 \mathrm{~m}$ on the mainland, and $750-1600 \mathrm{~m}$ on the Caribbean Islands.

Sticherus furcatus is characterized by the slender axes, short, trimerous aphlebiae, lanceolate last axes, thin-textured, pinnatisect segments with scatteredly ciliate margins, narrowly lanceolate, stoutly hyaline axis scales, usually bicolorous, basally dark, marginally hyaline and ciliate bud scales, scatteredly scaly midveins with simple to forked scales, and obscure veinlets with whitish, lax, star-shaped scales. It is most similar to $S$. compactus, which is larger overall, has thicker, more strongly protruding axes, pinnatisect to remote segments, rigid to stoutly hyaline, marginally hardened axis and bud scales, darkened and somewhat raised veinlets with somewhat thicker scales, and partly rigid, star-shaped midvein scales.

25. Sticherus albus J. Gonzales sp. nov.

Type. St. Vincent, Richmond Peak, Morne Garou Mountains, 900-1050 m, 15 Apr 1947, Morton 4946 (holotype, US).

Rhachis crassa, squamis persistentibus, aphlebiis trimeris provisa, perfecte pectinata. Gemma apicalis magna, perspicue squamata. Indumentum segmentorum paginae abaxialis densum (praecipue ad costam, sparse ad venulas), squamae longe lanceolatae, concolores pallide aurantiacae, hyalinae, membranaceae, cellulis rectangularibus ad linearibus, apice fimbriata, marginibus ciliatis.

Plants medium to large, robust. Rhizome unknown. Petiole 3-5 mm thick, castaneous, subpaleaceus. Rachis ca. $15 \mathrm{~cm}$ long between pinnae, the scales large, pale orange; 
aphlebiae trifoliate. Fiddlehead $1.5-2 \mathrm{~cm}$ in diameter, completely covered with large and usually concolorous pale orange scales. Bud large, ascending and opening rapidly, the scales narrowly-long lanceolate, basally rounded, apically fringed, 2.5-4 x 0.5-0.8 mm, gradually bicolorous, brown to opaque whitish margins, usually the darkened cells are restricted to the bases but sometimes found in the scale center, the margins hyaline with numerous, delicate cilia $1 / 8 \times$ the scale length, cell texture stoutly hyaline and basally relatively rigid, cells hexagonal to linear, forming a linear to ill-defined texture; the shape and size of the bud scales are quite consistent in a given plant. Pinnae $35-40 \mathrm{~cm}$ long, 2- to 3 -forked, $1^{\text {st }}$ axis $3.5-6 \mathrm{~cm}$ long and 2-3 mm thick, usually shorter than the $3^{\text {rd }}$, not pectinate, $2^{\text {nd }}$ axis $5-6 \mathrm{~cm}$ long and $2-2.5 \mathrm{~mm}$ thick, pectinate, usually with short aphlebiae, $3^{\text {rd }}$ and distal axis (10)25-30 cm long and 1-1.5 mm thick, pinnatisect, 4-7 cm wide with segments, lanceolate, with 2.5-3 segments per $\mathrm{cm}$, proximal internal segments gradually reduced and overlapping; scales adaxially mixed, one type star-shaped, $0.1 \mathrm{~mm}$ in diameter, lax, the margins with a few cilia $1-2 \times$ the scale length, the second type linear, ca. $2 \mathrm{~mm} \times 0.1 \mathrm{~mm}$, the margins with few, short cilia; abaxially and laterally densely scaly, the scales lanceolate, basally truncate, apically fringed, $1.5-3 \times 0.2-0.6(1) \mathrm{mm}$, the shorter ones usually on the abaxial surface and the larger and narrower ones lateral, pale orange, the margins with unequal and thin cilia $1 / 10 \mathrm{x}$ the scale length, cell texture opaque-hyaline, the cells narrowly hexagonal to linear, sometimes ill-defined, forming a vermiculate surface. Segments $2.5-4.5 \mathrm{~cm}$ long and 2-2.5 mm wide, linear, semi-chartaceous with margins narrowly revolute; adaxially glabrous; abaxially with slightly raised veinlets, glabrous or sparsely scaly, the scales spreading, lax, starshaped, whitish, hyaline; midvein densely scaly, the scales proximally linearlanceolate and distally round-lanceolate, apices long-fringed, 0.8-1.5 x 0.2-0.5 mm, pale orange, the margins with straight, thin cilia $1 / 4 \times$ the length of scale, cell texture hyaline with rectangular to irregular cells. Sori medial, not reaching the segment apices, not nested within scales, 10-15 pairs per segment, 3-5(6) sporangia per sorus. 


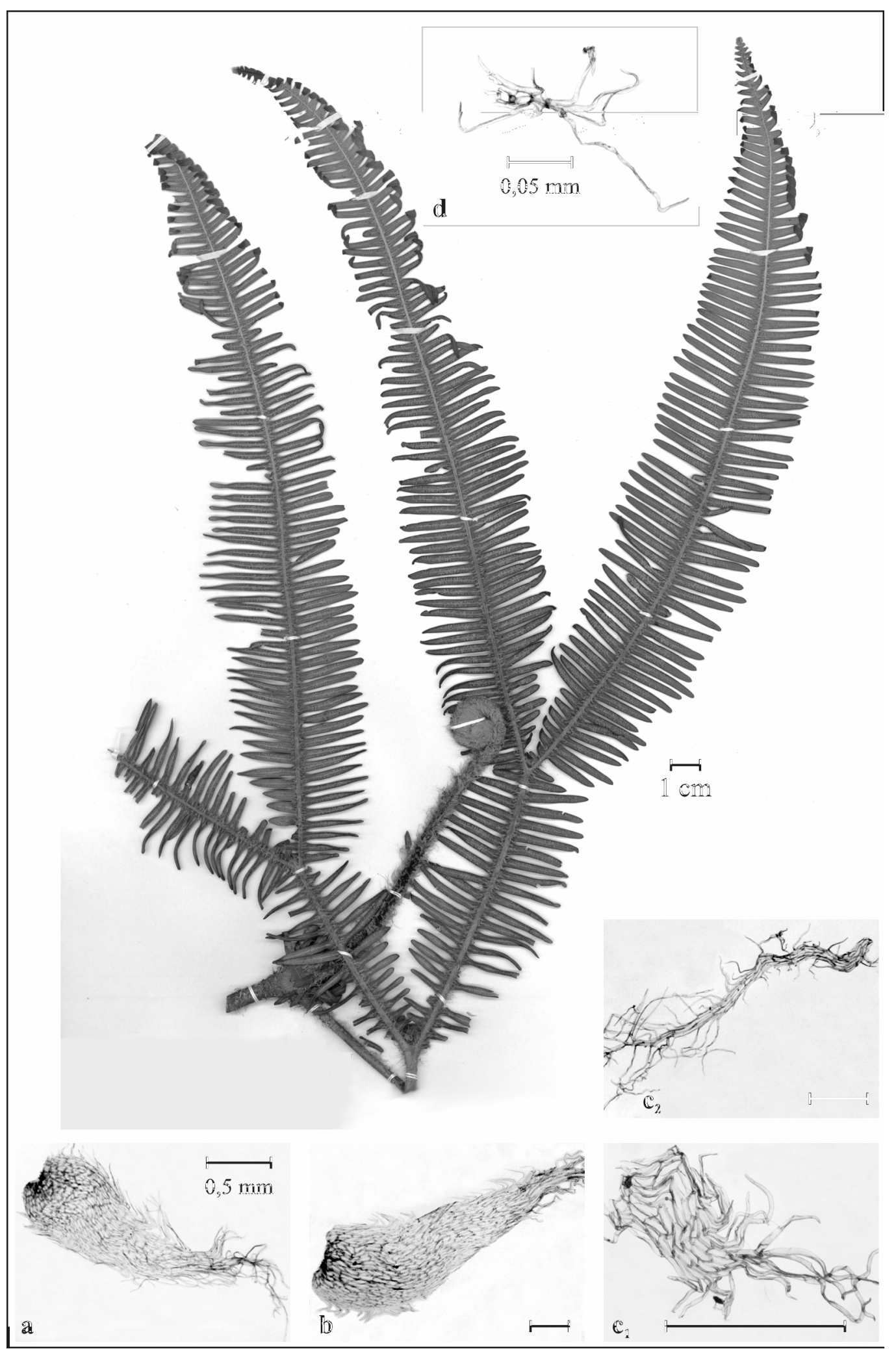

Fig 18. Sticherus albus J. Gonzales sp. nov., a) abaxial axis scales; b) bud scales; $c_{1}$ ) midvein scales; $c_{2}$ ) linear midvein scales; d) veinlets scales. Morton 4946 (holotype US). 
Distribution and ecology. Mountains of Honduras (900-2000 m) and the Caribbean islands of Hispaniola, St. Kitts, Nevis, Dominica, Guadaloupe, and Martinique (600$1100 \mathrm{~m}$ ). Locally common in humid montane forest, often in mossy ridge forest and along banks.

This species characterized by a combination of thick axes, fully pectinate, broadly lanceolate ultimate two axes, dense, persistent scales on the rachis, large, trimerous aphlebiae, large fiddleheads with conspicuous scales, a dense indument abaxially on the segments, densely scaly midveins, and sparse scales on the veinlets. The scales are mostly long-lanceolate with fringed apices, concolorous pale orange, opaque-hyaline with rectangular to linear cells, and have densely ciliate margins. Some bud scales have darkened bases. Sticherus albus is most similar to $S$. pallescens in general aspect and scale pattern, but that species has the ultimate two axes totally glabrous, relatively broader scales, and narrower midvein scales. It also resembles $S$. tomentosus because of its large size, scales, aphlebiae, and the scale texture, but $S$. tomentosus has a much denser indument abaxially, more prominent veinlets, larger, darker midvein scales, and mostly bicolorous scales.

This species has been identified in herbaria mostly as Sticherus furcatus (L.) Ching. However, that name is based on a plate by Plumier that cannot with certainty be assigned to any of the four species of Sticherus related to $S$. ferrugineus and $S$. albus that are currently known from the Lesser Antilles (see also under doubtful names).

26. Sticherus pallescens (Mett.) Vareschi, Fl. Venez. 1: 180. 1969.

Gleichenia pallescens Mett., Ann. Sci. Nat. Bot. Sér. 5, 2: 267. 1864. Type.

Colombia, Lindig 273 (holotype. P; Photo BM).

Gleichenia bicolor H. Christ, Bull. Herb. Boissier II, 6: 279. 1906. Type. Costa Rica, Rio Navarro, Werckle s.n. (holotype, P not seen).

Plants large, robust. Rhizome 3.5-5 mm thick, dark brown, densely scaly, the scales falcate, lanceolate, acuminate, 3-4(6) x 1-1.4 mm, dark brown, the margins with short setae, cell texture rigid with linear cells. Petiole over $30 \mathrm{~cm}$ long and 3-5 mm 
thick, castaneous, rough, subpaleaceous. Rachis ca. 20-40 cm long between pinnae, the scales dark brown; aphlebiae trifoliate. Fiddlehead ca. $1.5 \mathrm{~cm}$ in diameter, densely scaly, the scales appressed, large, whitish to pale orange. Bud large, ascending and opening rapidly, the scales lanceolate, basally rounded to cordate, (1.8)2-3(4) x 0.5-0.8 mm, bicolorous with dark brown bases or completely dark with whitish margins, the margins with numerous, delicate, slightly curled cilia $1 / 10 \mathrm{x}$ the scale length, cell texture stoutly-hyaline, the cells hexagonal to linear, forming an opaque surface; the shape and size of the bud scales are quite consistent in a given plant. Pinnae $35-60 \mathrm{~cm}$ long, 3- to 4-forked, $1^{\text {st }}$ axis 7-14 $\mathrm{cm}$ long and 2-3.5 mm thick, occasionally longer than the $2^{\text {nd }}$, not pectinate, $2^{\text {nd }}$ or $3^{\text {rd }}$ axes $10-15 \mathrm{~cm}$ long and 1.5-3 mm thick, when 4-forked, $4^{\text {th }}$ axis lanceolate, ca. $50 \mathrm{~cm}$ long pinnatifid, 3$5 \mathrm{~cm}$ wide with segments, with 2 segments per $\mathrm{cm}$; scales adaxially mixed, one type triangular, 0.4-0.6 x $0.1 \mathrm{~mm}$, the second type linear, hair-like, $3-5 \times 0.01-0.1 \mathrm{~mm}$, both scale types hyaline with dark orange parts formed by some hardened cell walls, cell texture rectangular-linear or irregular; abaxially moderately to densely scaly, the surface scales ovate to linear, the lateral scales mixed, one type square with a long and twisted apex, the second type lanceolate, 1-3 x 0.2-0.6 mm, brilliant orange; abaxial scales mostly bicolorous, the margins straight with short, irregular cilia, the cells hexagonal to irregularly very narrow, the cell walls thick, protruding from the scale surface. Segments linear-oval, subchartaceous, all the proximal internal segments overlapping, the first proximal segment longer than the adjacent segment, (3)4-6 x 2-3.5 mm, the margins chartaceous, ciliate; adaxially glabrous; abaxially with scales only on the midvein, the margins, and around the sori; midvein scales triangular with an apical hair, ca. $0.2 \mathrm{x}$ ca. $0.1 \mathrm{~mm}$, ca. $4-7$ irregular rows of cells wide, hyaline to brilliant orange, the margins with few, thick cilia 1/2-1/3 x the scale length; scales of the margins and around sori arachnoid, orange-dusty. Sori medial, not reaching segment apex, densely nested within arachnoid scales, 13-24 pairs per segment, 4-5 sporangia per sorus.

Distribution and ecology. Mountains in Costa Rica, Panama, Colombia, and Venezuela. Locally common inside forest, on bluffs, and along roadsides in humid montane forest at $1200-2200 \mathrm{~m}$. 
Sticherus pallescens is a large species with inframedial sori, thin-textured segments with translucent, thin veinlets, pinnatifid segments, abaxially densely scaly proximal axes grading into glabrous distal axes, large fiddleheads with conspicuous, long, whitish scales, lanceolate, whitish axis and bud scales with short, slender cilia and finely grated, hexagonal to linear cells, and basally hardened bud scales. It is most easily confused with $S$. albus, which, however, has scaly axes and midveins.

Two specimens from Bolivia (Bolivia, La Paz, Caranavi, Serranía Bella Vista, 1500 m, Kessler 11280, LPB, GOET, UC; Bautista Saavedra, Pauji-Yuyo, between Apolo and Charazani, 1200 m, Kessler 10054, LPB, GOET, UC) resemble S. pallescens, but have abaxial axis scales on the last axes, while $S$. pallescens generally has glabrous last axes. Unfortunately, the Bolivian material is fragmentary and sterile, and while it may represent a distinct taxon, it is for now best maintained under S. pallescens.

27. Sticherus rubiginosus (Mett.) Nakai, Bull. Natl. Sci. Mus. 29:28, 1950.

Gleichenia rubiginosa Mett. Ann. Sci. Nat. Bot., sér. 5, 2: 267. 1864. Dicranopteris rubiginosa (Mett.) Maxon, Contr. U.S. Natl. Herb. 24: 50. 1922. Type. Colombia, Puente Nacional, 1650 m, Lindig 71 (holotype, B; isotype, US).

Plants medium-sized. Rhizome 1-2(3) mm thick, dark brown, the scales deciduous, spreading, lanceolate, acuminate, 2-3(4.5) x 0.3-0.6 mm, dark brown, the margins with uniformly arranged setae, cell texture mixed, rigid with usually hyaline bases, the cells narrowly hexagonal cells. Petiole 1.5-2.5(3.5) mm thick, 10-60 cm long, dark castaneous, rough. Rachis ca. 20-40 cm long between pinnae, subpaleaceous, the scales bicolorous, dusty orange with dark brown rows; aphlebiae trifoliate to simple. Fiddlehead ca. $8 \mathrm{~mm}$ in diameter, moderately scaly, the scales matted, speckled, dark orange with blackish rows. Bud large, blackish, ascending and opening rapidly, the scales narrowly lanceolate, (1)2-4 x (0.2)0.4-0.8 mm, usually bicolorous orange with dark brown margins, the margins with setae $1 / 25 \mathrm{x}$ the scale length, and/or with basal cilia 1/11 x the scale length, cell texture stoutly hyaline, rigid on the scale margins, the cells rectangular to linear; shape and size of the bud scales are quite consistent in a given plant but scales of old ends are completely rigid. Pinnae 20-50 cm long, 2- to 4-forked, $1^{\text {st }}$ axis (2.5)4-7(9) $\mathrm{cm}$ long and 1.5-2 mm 
thick, with trifoliate to simple aphlebiae, not pectinate, $2^{\text {nd }}$ axis (3)7-30(50) $\mathrm{cm}$ long and 1-1.5 mm thick, occasionally with proximal, internal segments, $3^{\text {rd }}$ axis (6)20-40 $\mathrm{cm}$ long and 1-1.5 $\mathrm{mm}$ thick, $1.8-40 \mathrm{~mm}$ wide with segments; $4^{\text {th }}$ axis linearlanceolate, 9-20 cm long, 0.5-1 $\mathrm{mm}$ thick, pectinate, 10-26 mm wide with segments, basally and apically with gradually reduced segments; scales adaxially mixed, one type square to irregularly shaped, 0.2-0.7 x 0.05-0.2 $\mathrm{mm}$, the second type linear, 1.5$3 \times 0.03-0.2 \mathrm{~mm}$, both scale types hyaline with dark brown parts formed by some hardened cell walls, the cells hexagonal to linear; abaxially and laterally moderately to densely scaly, the scales lanceolate to linear, apically fringed or with 2 long cilia, (0.8)1.7-2.5(4.7) x 0.2-0.4 mm, orange to usually bicolorous with brown margins and orange bases, the margins with few cilia $1 / 6 \mathrm{x}$ and setae $1 / 13 \mathrm{x}$ the scale length, cell texture mixed, usually marginally hardened, centrally hyaline with rigid parts. Segments linear-oval, subchartaceous, proximal internal segments gradually decreasing, the first proximal segment shorter than the adjacent, 3-4(4.5) cm long and (4)9-17(25) mm wide, the margins slightly revolute; adaxially glabrous; abaxially scaly only on the midveins; midvein scales mixed, one type triangular with two apical cilia, 0.3-0.6 $\times 0.01-0.1 \mathrm{~mm}$, the second type linear, 2 cell rows wide, both scale types orange-dusty to dark brown, the margins ciliate or setose, cell texture hyaline with hardened parts, specially apically, the cell rectangular to irregular. Sori medial to inframedial, not reaching the segment apex, not nested within scales, (5)819 pairs per segment, (3)4-6 sporangia per sorus.

Distribution and ecology. Locally common in the mountains of Guatemala, Costa Rica, Puerto Rico, Trinidad, Venezuela, Colombia, Ecuador, Peru, and Bolivia. Inhabits open habitats in humid montane forest, along roads, on landslides, and near streams at (800)1400-3250 m.

Sticherus rubiginosus belongs to a group of five closely related species, $S$. rubiginosus, S. brittonii, S. strictissimus, S. farinosus, and S. boliviensis, that have frequently been considered to be conspecific (e.g., by Tryon \& Stolze, 1989, Østergaard \& Øllgaard, 2001). All of them have lanceolate axis and bud scales with a marginal to central pattern of scale hardening, but they differ from each other in the degree of separation of the segments, the shape of the midvein scales, the differentiation of the veinlets, and to some degree in the pattern of scale hardening 
(Tab. x). Also confusingly similar, but probably not as closely related are $S$. melanoblastus, S. peruvianus, and S. lechleri. Their differences are discussed under the respective species.

Sticherus rubiginosus is recognized by the inframedial sori that reach the segment apex, raised veinlets, trimerous aphlebiae, deeply pinnatifid segments, rigid, spreading bud scales, densely scaly abaxial axes with narrowly lanceolate, bicolorous scales, linear, apically rigid midvein scales, and rhizomes lacking squamophores. It may be confused with $S$. lechleri, which lacks hardened scales, and S. melanoblastus, which lacks aphlebiae and has nested sori.

A collection by Lehmann (s.n., prob. Colombia, V, no. BT 1024) represents a monstruous form of presumably this species with reduced segments resembling the plant described by Maxon $(1909,1912)$ for S. bifidus.

28. Sticherus brittonii (Maxon) Nakai Bull. Natl. Sci. Mus. 29: 15. 1950.

Dicranopteris brittonii Maxon, Contr. U.S. Natl. Herb. 24: 47. 1922. Gleichenia brittonii (Maxon) C. Chr., Index Fil. Suppl. 3: 106. 1934. Type. Trinidad, Mount Tocuche, Britton et al. 1352 (holotype, US; isotype, NY).

Plants medium-sized to large, semirobust. Rhizome unknown. Petiole 0.3-0.5 mm thick and ca. $50 \mathrm{~cm}$ long, dark castaneous, rough. Rachis ca. 20-35 cm long between pinnae, subpaleaceous, the scales dusty orange to brown; aphlebiae pinnatifid.

Fiddlehead ca. $5 \mathrm{~mm}$ in diameter, densely scaly, the scales spreading, speckled, dark orange with blackish cell rows. Bud large, usually dark orange to castaneous, ascending and opening rapidly, the scales narrowly lanceolate, long acuminate, apically fringed, $1.8-3 \times 0.3-0.6 \mathrm{~mm}$, dark orange to bicolorous with dark castaneus apices or completely dark brown, the margins with setae or with short, straight cilia ca. $1 / 15 \mathrm{x}$ the scale length, cell texture fully hardened or mixed stoutly hyaline with rigid peripheral and distal parts of the scale body, the cells narrowly hexagonal; shape and size of the bud scales are quite consistent in a given plant but scales of older parts are usually more rigid. Pinnae 30-50 cm long, 2- to 3-forked, axes usually whitish and/or shiny brown, $1^{\text {st }}$ axis 3-5 $\mathrm{cm}$ long and 1.5-2 $\mathrm{mm}$ thick, not pectinate, $2^{\text {nd }}$ axis 5-12 cm long and ca. $1.5 \mathrm{~mm}$ thick, usually only with scattered internal segments, subpaleaceus, $3^{\text {rd }}$ axis linear, $20-30 \mathrm{~cm}$ long and ca. $1 \mathrm{~mm}$ thick, 
pinnatisect, $2.7-4 \mathrm{~cm}$ wide with segments, with 2-3 segments per $\mathrm{cm}$, proximal segments gradually reduced; adaxially glabrous; abaxially and laterally moderately scaly, the scales $1.5-3 \times 0.3-0.5 \mathrm{~mm}$, dusty orange to bicolorous with darker apices, similar in shape and hardening pattern to the bud scales but usually hyaline with only the apical margin hardened and fringed. Segments linear-oval, 1.3-2 cm long and 2.5$3 \mathrm{~mm}$ wide, subchartaceous, the margins narrowly revolute, abaxial surface whitish, glabrous; adaxially glabrous; midvein scales scattered, Y-shaped, ca. 0.4 x $0.05 \mathrm{~mm}$, whitish and hyaline; veinlets raised, bearing simple, whitish fibrillae. Sori inframedial to medial, reaching the segment apex, not nested, 7-15 pairs per segment, (3)4-5 sporangia per sorus.

Distribution and ecology. Endemic to Mount Tocuche on Trinidad. Elevation and habitat unknown.

This species is very similar to $S$. rubiginosus and has usually been considered to be conspecific, but it differs in its thicker axes and larger overall size, medial sori, pinnatisect to remote segments, linear, apically forked, orange midvein scales, simple fibrillae on the veinlets, and a papillaceous abaxial segment surface. It is also similar to $S$. strictissimus, but that species is much smaller with more triangular segments and has thicker, whitish midvein scales.

29. Sticherus farinosus (Kaulf.) J. Gonzales comb. nov.

Mertensia farinosa Kaulf., Wes. Farnkr. 37. 1827. Gleichenia farinosa (Kaulf.) Hook., Sp. Fil. 1: 9. 1844. Type. Guadalupe?, collector unknown (holotype, P).

Mertensia subtrisperma Fée, Mem. Foug. 11: 122, t. 32. f. 2. 1866. Type.

Guadeloupe, L' Herminier s.n. (holotype, P).

Plants medium-sized, semirobust. Rhizome 1.5-2.5 mm thick, dark brown, the scales deciduous, spreading, lanceolate, long acuminate, 3-5.5 x 0.3-0.6 mm, speckled orange with dark brown, the margins with few, thin setae and/or cilia, cell texture mixed, marginally rigid. Petiole $1.5-2 \mathrm{~mm}$ thick and 8-20 cm long, dark castaneous, rough. Rachis ca. (3)5-10 cm long, subpaleaceous, the scales orange to dusty whitish; 
aphlebiae long, simple. Fiddlehead ca. $5 \mathrm{~mm}$ in diameter, the scales dusty orange. Bud small, ascending and opening rapidly, the scales lanceolate to triangular, 1.22.5(4) x 0.2-0.5 mm, usually bicolorous, orange with dark brown margins, the margins with setae and/or cilia ca. 1/12 x the scale length, cell texture hyaline with rigid margins, the cells rectangular to linear; the shape and size of the bud scales are quite consistent in a given plant but scales of older parts are usually more rigid. Pinnae 10-25 cm long, 2-forked, $1^{\text {st }}$ axis 1-2 cm long and 0.5-1 mm thick, internal segments persistent, $2^{\text {nd }}$ axis $7-12 \mathrm{~cm}$ long and $0.5-1 \mathrm{~mm}$ thick, lanceolate, pectinate, 1.5-2.5 mm wide with segments, with ca. 4 segments per $\mathrm{cm}$; adaxially glabrous; abaxially and laterally moderately to densely scaly, the scales narrowly lanceolate, apically fringed, 1-3 x 0.2-0.6 mm, orange to bicolorous with dark orange margins, the margins with few cilia and/or setae 1/5-1/9 the scale length, cell texture hyaline to mixed with hardened scale margins. Segments narrowly oval, subchartaceous, the margins slightly revolute, proximal internal segments gradually decreasing, usually overlapping, $0.5-1.5 \mathrm{~cm}$ long and 1-1.7 mm wide; adaxially glabrous; abaxial surface densely papillose; midvein scaly, the scales linear-triangular to irregularly shaped, $0.1-0.3 \times 0.1-0.05 \mathrm{~mm}$, orange, the margins with few cilia 1-2 $\mathrm{x}$ the scale length, cell texture hyaline with linear cells; veinlets raised, parallel, brown, bearing simple, orange fibrillae. Sori medial, 7-10 pairs per segment, 3-4 sporangia per sorus.

Distribution ane ecology. Guadeloupe and Martinique in the Lesser Antilles. At 900-1500 m in wet forest, sometimes on boggy ground with Sphagnum.

This is yet another species closely related to S. rubiginosus, and in particular to $S$. brittonii. Relative to that species, it is much smaller overall but with longer midvein scales. Among S. rubiginous and its allies, this is the only one with squamophores on the rhizome. It is also the only representative of this group on the Lesser Antilles, while the others occur on Trinidad, in the Andes, and in southeastern Brazil. 
30. Sticherus strictissimus (H. Christ) Copel., Ann. Cryptog. Phytopatol. 5: 28. 1947.

Gleichenia strictissima H. Christ, Bull. Herb. Boissier, sér. 2, 5: 13. 1905.

Dicranopteris strictissima (H. Christ) Underw., Bull. Torrey Bot. Club 34: 261. 1907. Type. Costa Rica, Wercklé 215 (holotype, P; isotype US).

Gleichenia glaucina H. Christ, Bull. Herb. Boissier, sér. 2, 6: 283. 1906. (Type, Costa Rica, La Palma, Werckle s.n. (holtype, ?).

Plants small to medium-sized. Rhizome 1-1.5 mm thick, dark brown, the scales deciduous, spreading, lanceolate, acuminate, (1.3)1.8-2.2 x 0.3-0.6 mm, dark brown, the margins with regulary arranged setae, cell texture rigid with rectangular narrow cells. Petiole 10-35 cm long and 1-1.5 mm thick, dark castaneous, subpaleaceous. Rachis ca. 8-20 cm long between pinnae, subpaleaceous, the scales dark brown; aphlebiae absent. Fiddlehead large, ca. $3 \mathrm{~mm}$ in diameter, moderately scaly, the scales brilliant dark brown. Bud small, closed, the scales narrowly lanceolate, apically long-acuminate, 1-3 x 0.2-0.4 mm, usually bicolorous, orange with dark brown margins, the margins with cilia $1 / 10 \mathrm{x}$ and/or setae $1 / 17 \mathrm{x}$ the scale length, cell texture hyaline, marginally hardened, the cells rectangular to linear; shape and size of the bud scales are quite consistent in a given plant. Pinnae 10-30 cm long, 1- to 3forked, $1^{\text {st }}$ axis (2)4-13(21) cm long and $1 \mathrm{~mm}$ thick, pectinate, $2^{\text {nd }}$ axis $5-14 \mathrm{~cm}$ long and $0.5-1 \mathrm{~mm}$ thick, $3^{\text {rd }}$ axis $5-8 \mathrm{~cm}$ long and $0.5 \mathrm{~mm}$ thick, pinnatifid, $1-2 \mathrm{~cm}$ wide with segments, with 3 segments per $\mathrm{cm}$, distal axes narrowly lanceolate; adaxially glabrous or scaly, the scales long-linear, ca. $2.2 \mathrm{~mm}$ x 0.1 mm, 2-3 cell rows wide, the margins short-ciliate; abaxially and laterally moderately to densely scaly, the scales narrowly lanceolate, (1.2)1.6-2.4(3) x 0.2-0.4 mm, orange to bicolorous, usually with brown margins, the margins with few cilia $1 / 8 \mathrm{x}$ or setae $1 / 14 \mathrm{x}$ the scale length, cell texture mixed with rectangular to linear cells. Segments triangular, subchartaceous, proximal segments gradually decreasing, 0.7-1.4 cm long and 2-3 $\mathrm{mm}$ wide, the margins revolute; adaxially glabrous, papillate, scales abaxially only on the midvein; midvein scales in Y-shaped, ca. 0.4 x $0.05 \mathrm{~mm}$, whitish, hyaline. Sori inframedial, reaching the segment apex, not nested within scales, 10-15 pairs per segment, (3)4-5 sporangia per sorus. 
Distribution and ecology. Mountains of Costa Rica, Venezuela, Colombia, Ecuador, and Bolivia; to be expected in Peru. Locally common in Costa Rica and Ecuador, apparently rare elsewhere. Disturbed habitats in humid montane forest at 1400-2400 $\mathrm{m}$.

This species has usually been considered to be conspecific with $S$. rubiginosus of which it basically represents a dwarf form. Østergaard \& Øllgaard (2001) therefore believed that S. strictissimus and Gleichenia salesiana (see under doubtful names) represent precociously fertile specimens of $S$. rubiginosus. However, in addition to size, S. strictissimus also differs from S. rubiginosus in its shorter segments with pointed apices, less densely scaly rhizomes, simple to forked, thick, whitish fibrillae on the midvein, obscure veinlets with thick, whitish fibrillae, and abundant papillae on the segment surface. Based on all these differences it seems best to consider both forms as distinct species.

31. Sticherus remotus (Kaulf.) Chrysler, Amer. J. Bot. 31: 383. 1944.

Mertensia remota Kaulf. Enum. Fil. 39. Hook. Spec. Fil. I. 132. 1824. Dicranopteris remota (Kaulf.) Maxon, Contr. U.S. Natl. Herb. 24: 50. 1922. Gleichenia remota (Kaulf.) Sprengel, Syst. Veg. 4: 27. 1927. Type. Brazil, Ilha de Santa Catarina, Chamisso s.n. (holotype, LZ destroyed; isotype, LE? only description).

Gleichenia trachyrhizoma H. Christ., Bull. Herb. Boissier, sér. 2, 6: 280. 1906. Type. Costa Rica, Valle del Rio Navarro, Werckle s.n. (holotype, S).

Dicranopteris williamsii Maxon, Amer. Fern J. 2: 21. 1912. Type. Panama, Cana, $R$. S. Williams 917. (holotype, US).

Plants medium-sized to large, robust. Rhizome 2.5-3.5(4) mm thick, dark brown, rugose with squamophores ca. $0.2 \mathrm{~mm}$ long, the scales spreading, narrowly lanceolate, $1.5-2.5(4.2) \times 0.2-0.4(0.5) \mathrm{mm}$, dark brown to red, the margins setose, cell texture rigid with linear cells. Petiole 20-100 cm long and (1.5)2.5-3.5 mm thick, castaneous. Rachis ca $12-30 \mathrm{~cm}$ long between pinnae, subpaleaceous to deciduously 
scaly, the scales bicolorous, whitish and blac;, aphlebiae large, narrowly pinnatifid, overlapping. Fiddlehead ca. $0.5 \mathrm{~cm}$ in diameter, the scales deciduous, bicolorous. Bud small and opening rapidly, the scales triangular to lanceolate, apically fringed, (0.6)1.5-3 x (0.1)0.2-0.6 mm, completely black or usually bicolorous, basally orange and apically dark brown, the margins basally with cilia, distally with setae ca. $1 / 4 \mathrm{x}$ the scale length, cell texture mixed, basally hyaline and apically rigid to completely rigid with rectangular cells. Pinnae $30-50 \mathrm{~cm}$ long, 2- to 3-forked, $1^{\text {st }}$ axis (2.5)6-10 $\mathrm{cm}$ long and 1-2 mm thick, with trifoliate aphlebiae, pectinate or only with the internal segments, $2^{\text {nd }}$ and usually distal, axis (3)10-30(50) cm long and 1-2 mm thick, pectinate, $3^{\text {rd }}$ axis (14)25-40 $\mathrm{cm}$ long and 0.6-1.5 $\mathrm{mm}$ thick, remotely pinnatisect, (3)4.5-8(10) cm wide with segments, with (1.5)2-2.5 segments per $\mathrm{cm}$, linear-lanceolate; adaxially glabrous; abaxially and laterally moderately scaly, the scales mixed, one type reduced, 0.2-0.5 x ca. $0.1 \mathrm{~mm}$, the second type narrowly lanceolate, (0.8)1-1.7 x 0.2-0.7 mm, ca. 8 cell rows wide, both scale types bicolorous, the margins with irregular cilia $1 / 4 \mathrm{x}$ the scale length or setose with a long apical cilium, cell texture mixed, basally orange and hyaline, the rest of the scale rigid, dark brown. Segments (1.5)2.5-4.5 x 1.5-2(3) mm, linear, the margins flat to revolute, subchartaceous, the proximal internal segments usually overlapping, the margins chartaceous; veinlets thin, abaxially raised; adaxially glabrous; abaxially midvein and veinlets scaly; midvein scales mixed, one type triangular to rectangular, $0.2-0.8 \times 0.1-0.2 \mathrm{~mm}$, distally concolorous and proximally usually bicolorous with hyaline to rigid, dull cells, the margins with a few cilia 1/2-2 $x$ the scale length, the second type linear, ca. 2 x ca. $0.1 \mathrm{~mm}$, to 3 cell rows wide, the margins with few, short cilia; veinlets scales star-shaped, hyaline. Sori medial to inframedial, not nested in scales, (5)7-11 pairs per segment, 3-4 sporangia per sorus.

Distribution and ecology. Lower montane zone of Costa Rica, Panama, Trinidad, Venezuela, Guyana, Ecuador, Peru, Bolivia, and southeastern Brazil. Widespread but apparently nowhere common in humid forest, often nears streams, mostly at 400$1200 \mathrm{~m}$ but down to $100 \mathrm{~m}$ in Panama and up to $2450 \mathrm{~m}$ in Bolivia.

Sticherus remotus is readily identified species by its pinnatisect to remote, linear, narrowly revolute segments with slightly raised veinlets, narrow, elongate, trifoliate aphlebiae, apically hardening scales, rhizomes with large squamophores, 
short and dark abaxial axes scales, and hyaline, orange, triangular midvein scales, usually with rigid apices. The relationships of this species are presumably with $S$. nigropaleaceus, which has a similar pattern of scale hardening but has pectinate last axes and wider segments, and perhaps with $S$. chocoensis, which is of similar size and also has narrow, trifoliate aphlebiae but is densely scaly abaxially on the segments. S. remotus hybridised with $S$. ferrugineus to produce the tetraploid $S$. interjectus.

32. Sticherus melanoblastus (Alston) Østergaard \& B. Øllgaard, Flora of Ecuador No. 66, p. 144, 2001.

Gleichenia melanoblasta Alston, J. Wash. Acad. Sci. 48: 230, 1958. Type.

Colombia, Nariño, Putumayo, Quebrada Blanca, “along camino Precipicio, Río Afiladores", 2130 m, Ewan Joseph A. 16280, (holotype, BM, isotype, US).

Plants medium-sized, semirobust. Rhizome 2-3.5 mm thick, dark-brown, rugose with squamophores, the scales decisuous, spreading, lanceolate, acuminate with two apical setae, 1.6-3 x 0.3-0.6 mm, dark brown, the margins setose, cell texture rigid with hyaline base. Petiole ca. $25 \mathrm{~cm}$ long and 2.5-4.5 $\mathrm{mm}$ thick, castaneous to dark brown, rough. Rachis ca. 10-20 cm long between pinnae, subpaleaceous, deciduously scaly; aphlebiae absent. Fiddlehead ca. 3-5 mm in diameter, moderately scaly, the scales appressed, bicolorous, whitish with dark brown patches, cell texture hyaline to rigid. Bud small, ascending and opening rapidly, the scales narrowly lanceolate, basally truncate, $1-1.8 \times 0.2-0.5 \mathrm{~mm}$, dark brown to bicolorous with orange-hyaline parts, the margins with setae or cilia $1 / 10 \mathrm{x}$ the scale length, cell texture rigid to semiclathrate, the cells short and rectangular with hardened cell walls; the shape and size of the bud scales are quite consistent on a given plant, but scales of old parts are usually more rigid. Pinnae $20-55 \mathrm{~cm}$ long, axes 2 - to 3 -forked, $1^{\text {st }}$ axis $3-6 \mathrm{~cm}$ long and 2-2.5 $\mathrm{mm}$ thick, not pectinate, $2^{\text {nd }}$ axis $3-10(30) \mathrm{cm}$ long and ca. $1.5 \mathrm{~mm}$ thick, when pectinate, lacking the first proximal segments, $4.5-6.5 \mathrm{~cm}$ wide with segments, $3^{\text {rd }}$ axis lanceolate, usually apically conform, $14-35 \mathrm{~cm}$ long and $1-1.5 \mathrm{~mm}$ thick, fully pectinate, 3-4(6) $\mathrm{cm}$ wide with segments, with ca. 3 segments per $\mathrm{cm}$; adaxial scales mixed, one type stellate, ca. $0.5 \times 0.05-0.1 \mathrm{~mm}$, orange-hyaline to bicolorous, apically and marginally hardened, entire or with a few hyaline cilia ca. $1 \mathrm{x}$ the scale 
length, the second type linear, 1-1.8 $\times 0.1-0.2 \mathrm{~mm}$, ca. 2 cell rows wide, hyaline, the margins with cilia ca. $1 / 5 \mathrm{x}$ the scale length; abaxial scales mixed, one type lateral, narrowly lanceolate, 1-2-1.6 x 0.2-0.4 mm, brown to bicolorous with hyaline bases, the margins setose, the cells very narrowly rectangular, the second type on the axis surface, stellate or lanceolate, reduced, both scale types apically fringed. 
has aphlebiae, deeply pinnatifid segments, unnested sori, more lanceolate scales, and a marginal hardening pattern of scales.

33. Sticherus peruvianus (Maxon) A. R. Sm., M. Kessler \& J. Gonzales. Amer. Fern J. 89: 244-266. 1999.

Gleichenia peruviana (Maxon) Lell. Fieldiana, Bot. Pteridophyta of Peru I, 45, 1989. Dicranopteris peruviana, Maxon, Amer. Fern J. 33: 133. 1943. Type. Peru, Huanaco, Playapampa, Macbride 4510, (holotype, F; isotype, US)

Plants medium-sized, slender. Rhizome 2-3 mm thick, dark brown, the scales deciduous, narrowly lanceolate, acuminate, 1-2 mm x 0.3-0.6 mm, dark brown, the margins setose, cell texture rigid with rectangular to linear cells. Petiole ca. $20 \mathrm{~cm}$ long and 2-3.6 mm thick, castaneous, rugose. Rachis $\mathrm{ca} .14 \mathrm{~cm}$ long, subpaleaceous, the scales orange to brown; aphlebiae trifoliate with narrow segments. Fiddlehead 4$8 \mathrm{~mm}$ in diameter, moderately scaly, the scales spreading, brilliant-orange to speckled with dark brown rows. Bud ascending and opening rapidly, the scales longtriangular, (0.5)1.2-2 x (0.1)0.3-0.6 mm, orange to bicolorous with dark bases or completely dark with orange margins, the margins with short, thick cilia/setae, cell texture stoutly hyaline to semirigid with rectangular to irregular cells; shape and size of the bud scales are quite consistent in a given plant, but scales of old ends usually have a more rigid consistence. Pinnae $15-30 \mathrm{~cm}$ long, 2- to 4-forked, $1^{\text {st }}$ axis (3)5$8(11) \mathrm{cm}$ long and 1.2-2.2 $\mathrm{mm}$ thick, not pectinate, when more than 2-forked, $1^{\text {st }}$ axis longer than $2^{\text {nd }} ; 2^{\text {nd }}$ axis (3.5)4-8 cm long and 1-1.5 mm thick, not pectinate or when distal, 25-45 cm long and 0.8-1.5 mm thick, with segments $2-4.5 \mathrm{~cm}$ wide; $3^{\text {rd }}$ axis 2$4 \mathrm{~cm}$ long and $1 \mathrm{~mm}$ thick or when distal 15-30 cm long, 1-1.2 mm thick, with segments $1.8-3 \mathrm{~cm}$ wide; when 4-forked, usually $3^{\text {rd }}$ and $4^{\text {th }}$ axis equal in size, $8-22$ $\mathrm{cm}$ long and 0.5-1 $\mathrm{mm}$ thick, $1.5-2 \mathrm{~cm}$ wide with segments, narrowly lanceolate; adaxial scales mixed, one type square, 0.1-0.6 $\times 0.1-0.2 \mathrm{~mm}$, the second type linear, 1-1.6 $\times 0.08-1 \mathrm{~mm}$, both scale types hyaline, the margins short-ciliate, the cells rectangular; abaxially and laterally densely scaly, the scales triangular to lanceolate, apically fringed or with a long, contorted cilium, (0.3)0.6-1(1.8) x 0.1-0.4 mm wide, orange to speckled with dark brown bases, the margins whitish to orange with few cilia $1 / 6 \mathrm{x}$ the scale length, cell texture thick-hyaline with rectangular to irregular 
cells. Segments linear-oval, subchartaceous, pinnatisect, proximal internal segments gradually decreasing, usually overlapping, (0.8)1.2-2.5(3) cm long and (1.5)2-3.5 $\mathrm{mm}$ wide, the margins slightly revolute; adaxially glabrous; abaxially with scales usually only on the midvein; midvein scales triangular to irregular, $(0.2) 0.5-0.8(1) \mathrm{x}$ 0.1-0.2 mm, the margins ciliate, cell texture rectangular to irregular. Sori inframedial, not reaching the segment apex, not nested in scales, 13-19 pairs per segment, (3)4-6 sporangia per sorus.

Distribution and ecology. Andes of southern Ecuador (Zamora-Chinchipe), Peru, and Bolivia. Common, forming dense colonies in cloud forest, elfin forest, or on exposed ridges at 2000-3400 m.

This species has inframedial sori that do not reach the distal end of the segments and that lack arachnoid nest-forming scales, obscure veinlets that diverge at a wide angle, conspicuous, trimerous aphlebiae, deeply pinnatifid segments, and moderately dense, bicolorous axis, bud, and midvein scales that harden from the base and maintain hyaline margins with long, contorted cilia. The abaxial axis scales are lanceolate, and long-acuminate with fringed apices, while the bud scales are lanceolate with rounded bases. Most specimens examined of this species have a distinctive, up to $1 \mathrm{~mm}$ long, black fungal bodies on the abaxial segment surface.

Sticherus peruvianus is most similar to $S$. melanoblastus as both have bicolorous scales, but the latter species has parallel, raised veinlets, lacks aphlebiae, has more remote segments, nested sori, rhizomes with squamophores, thicker axes, and dark, setose scale margins. In S. peruvianus, the last axis is lanceolate with gradually reduced apices and bases, while in S. melanoblastus the bases are truncate.

34. Sticherus revolutus (Kunth) Ching, Sunyatsenia 5: 284. 1940

Gleichenia revoluta Kunth in H.B.K., Nov. Gen. Sp. P1. 1: 29. 1815. Mertensia revoluta (Kunth) Desv., Mém. Soc. Linn. Paris 6: 200. 1827. Type. Ecuador, Loja, Saraguro, Humboldt \& Bonpland s.n. (holotype, P; isotype B, US).

Gleichenia affinis Kuhn, Linnaea 36: 167. 1869. Dicranopteris affinis (Kuhn) Maxon, Cont. U.S. Natl. Herb. 24: 47. 1922. Sticherus affinis (Kuhn) Nakai, Bull. 
Natl. Sci. Mus. 29:13. 1950. Type. Peru, Puno, San Gabán, Lechler 2265 (holotype, $\mathrm{B}$; isotype, US).

Gleichenia affinis Kuhn var. bogotensis Hieron. Hedwigia 48: 286. 1909. Type. Colombia, Bogota, Stübel 421 (holotype, B).

Gleichenia affinis Kuhn var. pachensis Hieron. Hedwigia 48: 286. 1909. Type. Colombia, Bogota, 2900 m, Lindig 116 (holotype, B).

Gleichenia subandina Sodiro, Recenst. Crypt. Vasc. Quit. 5. 1883. Sticherus subandinus (Sodiro) Nakai, Bull. Natl. Sci. Mus. 29: 1950. Type. Ecuador, Pichincha, El Corazón and Atacazo, Sodiro s.n. (holotype, K; photo, BM, US).

Dicranopteris costaricensis Underw., Bull. Torrey Bot. Bot. Club 34: 253. 1907, Gleichenia costaricensis (Underw.) C. Chr., Index Fil. Suppl. 1: 44. 1913. Sticherus costaricensis (Underw.) Chrysler, Amer. J. Bot. 31: 483. 1944. Type. Costa Rica, Alajuela, Volcan Póas, Smith 6859 (holotype, NY; isotypes: B, MO, US).

Plants small to medium-sized, slender. Rhizome (1.5)2-4 mm thick, dark-brown, rough, with squamophores, densely scaly, the scales often deciduous, longlanceolate, (1.4)2-3(4) x 0.5-0.8 mm, orange to dark-brown, the margins setose, cell texture rigid with rectangular cells. Petiole $3-5 \mathrm{~mm}$ thick and more than $30 \mathrm{~cm}$ long, castaneous. Rachis ca. 20-40 cm long between pinnae, deciduous, brittle, dark brown to reddish; aphlebiae pinnatifid to lobulate. Fiddlehead ca. 3-5 $\mathrm{mm}$ in diameter, densely scaly, the scales large, golden-orange. Bud small, ascending and opening rapidly, the scales lanceolate to narrowly lanceolate, bases cordate to truncate, apically extended to a long pectinate hair or fringed cilium 0.2-0.7(0.9) $\mathrm{mm}$ long, (0.6)1.5-2.5(4) x 0.4-1 mm, brilliant orange to dark brown-reddish, the margins with numerous, delicate, slightly curled cilia ca. $1 / 4 \mathrm{x}$ the scale length, cell texture stoutly hyaline, with rectangular, well-defined cells. Pinnae 15-30 cm long, 3- to 5-forked, $1^{\text {st }}$ axis usually longer that $2^{\text {nd }}$ axis, (2)4-10 cm long and $1-1.5 \mathrm{~mm}$ thick, not pectinate, $2^{\text {nd }}$ and $3^{\text {rd }}$ axis shorter than the $1^{\text {st }}, 2-6 \mathrm{~cm}$ long and $0.5-1 \mathrm{~mm}$ thick, $2^{\text {nd }}$ usually not pectinate but the last two distal axes pectinate, $4^{\text {th }}$ axis narrowly linear, (8) 10-20(30) $\mathrm{cm}$ long and 0.5-1 mm thick, deeply pinnatifid, (0.6)1-2 cm wide with 
segments, with 3-4 segments per cm; scales adaxially sometimes deciduous, proximally rectangular, $0.2-0.7 \times 0.1 \mathrm{~mm}$, the margins with a few cilia $1 / 2-1 \times$ the scale length, distally long, hair-like, sometimes with a tiny basal scale body, 2-7 x 0.06-0.01 mm, both scales types found usually in Andean specimens, the color varying geographically: brilliant orange in Central America, dark orange to dusty in the Andes, cell texture hyaline with rectangular cells; abaxially and laterally moderately to densely scaly, the scales long-lanceolate, apically with a pectinate hair 0.5-1(2) mm or long-fringed (usually in specimens from Costa Rica), (0.7)1.5-3(5) x (0.2)0.4-0.7 mm, usually concolorous brilliant orange or bicolorous with dark orange bases, the margins with cilia 1/4 the scale length, cell texture grated-hyaline, sometimes with hardeneds basal cells (usually Andean specimens). Segments 0.5-1 $\mathrm{cm}$ long and (1.5)2-2.5 mm wide, triangular to oval, the margins strongly revolute, coriaceous; veinlets diverging, glabrous; adaxially glabrous; abaxially densely scaly on the midvein, the scales narrowly long-lanceolate to linear, with one or two apical cilia (0.3)0.6-1.5 mm, 1-2(4) $\times(0.06) 0.1-0.2 \mathrm{~mm}$, the margins with scattered cilia 1/4-1 x the scale length. Sori medial to supramedial, 4-6(14) pairs per segment, 3-5 sporangia per sorus.

Distribution and ecology. High mountains in Costa Rica, Panama, Venezuela, Guyana, Colombia, Ecuador, Peru, Bolivia, and southeastern Brazil. Common in open habitats in humid montane forest, around timberline, and in shrubby páramos at (1000)1400-3300 m.

Sticherus revolutus is characterized by the short, oval to triangular segments with strongly revolute margins, abaxially densely scaly midveins with longlanceolate to linear scales, deeply pinnatifid to pinnatisect segments covered halfway by the abaxial axis scales, hair-like scales on adaxial axes, and long-acuminate, hairlike apices on the scales of the abaxial axes and buds. All scales of this species lack hardened parts. It is most similar to S. pruinosus and S. nervatus, both of which were considered to be conspecific by previous workers, but $S$. pruinosus bears segments on all axes, has sparser scales, and lacks squamophores on the rhizome, while $S$. nervatus has thicker, raised veinlets, more rounded segments, broader, roundedlanceolate abaxial axis scales that often cover almost the entire segment, and also bears segments on all axes. 
This is the most widespread Neotropical species of the genus. Accordingly, it also shows some morphological variation, notably in overall size. Stable characters are the segmented hair-like scales adaxially on the axes, pectinate distal axes, large, trimerous aphlebiae on the proximal axes, and the relative length of the axes. However, on Hispaniola there are some distinct, small specimens with rugose rhizomes, very short squamophores, 1- to 2-forked pinnae, reduced or lacking aphlebiae, and fully segmented axes (Dominican Republic, De la Vega, Loma Rosilla, 2600 m, 1912, Fuentes 1786, G, U; Parque Nac. J. A. Bermúdez, entre Compartición y Pico Duarte, 2400-2700 m, 1987, Zanoni et al. 37724, NY; Valle Nuevo on the road to San José de Ocoa, 2500 m, 1967, Gerald et al. 727, NY; Haiti, Ouest, $1700 \mathrm{~m}, 1955$, Proctor 10894, US). Since the scales are identical to those of $S$. revolutus, these aberrant specimens are provisionally maintained under that species.

35. Sticherus nervatus J. Gonzales sp. nov.

Type. Bolivia, La Paz, Nor Yungas, 8 km from Chuspipata to Coroico, Kessler M., $J$. Gonzales, K. Bach \& A. Portugal 12113 (holotype UC; isotypes LPB, GOET).

Affinis S. revoluto, differt venulis in pagina abaxiali evidenter prominentibus, fere parallelis, squamis reductis, frondibus 4- ad 6-furcatis, rhachidibus fere perfecte pectinatis, rhachide primaria longa, rhachides sequentes valde excedente. Aphlebiae et squamophori deficientes. Pagina abaxialis rhachidorum dense squamata, squamis obtegentibus minimum dimidium segmentis vicinis.

Plants small to medium-sized. Rhizome 1.5-2 mm thick, dark-brown, lustruous, deciduously scaly, the scales lanceolate, $1.5-2$ x 0.2-0.4 mm, dark brown, the margins with slender setae, cell texture rigid with hexagonal to linear cells. Petiole ca. $25 \mathrm{~cm}$ long and 1-3 mm thick, dark brown to reddish, brittle. Rachis ca. 20-35 cm long between pinnae, subpaleaceus, the scales orange; aphlebiae absent. Fiddlehead ca. 2-5 $\mathrm{mm}$ in diameter, densely scaly, the scales opaque brown. Bud small, appressed, the scales lanceolate, basally rounded, apically glandular or with a short hair, 1-3.2 x 0.2-0.6(1) mm, opaque orange, the margins with short, often abraded cilia, cell texture hyaline to stoutly-hyaline with rectangular cells. Pinnae $15-35 \mathrm{~cm}$ 
long, axes (2)4- to 6- forked, pectinate from the $2^{\text {nd }}$ axis onwards, $1^{\text {st }}$ axis longer than the following, 5-15 cm long and 1-3 mm thick, usually only with proximal internal segments, $2^{\text {nd }}$ and $3^{\text {rd }}$ axes (2)6-10 $\mathrm{cm}$ long and $1-2.5 \mathrm{~mm}$ thick, $4^{\text {th }}$ axis the longest, $4-15(20) \mathrm{cm}$ long and $0.8-1 \mathrm{~mm}$ thick, $5^{\text {th }}$ and $6^{\text {th }}$ axes narrowly linear and uniform, ca. 5-10 cm long and (5)9-13 mm wide with segments, the last two axes usually of similar length; scales adaxially usually deciduous, proximally rectangular, ca. $0.4 \mathrm{x}$ $0.2 \mathrm{~mm}$, the margins with very few cilia $1 \mathrm{x}$ the scale length, distally long-linear, sometimes apically long-ciliate, (1.2)2.5-4 x (0.05)0.1-0.5 mm, ca. 2-3 cells row wide, the margins with few cilia ca. $1 / 12 \mathrm{x}$ the scale length, all scales whitish to orange, cell texture hyaline with rectangular cells; scales abaxially and laterally dense, ovate-lanceolate to narrowly lanceolate, apically usually glandular or bearing a short, pectinate hair, (0.8)1.4-3(4) x (0.2)0.4-0.8(1) mm, concolorous, beige-brown, the margins with cilia $1 / 15 \mathrm{x}$ the scale length, cell texture grated-hyaline. Segments (2)5-7 x (1)1.5-2.5 mm, oval, the margins strongly revolute, coriaceous; adaxially glabrous; veinlets nearly parallel, abaxially strongly raised; abaxially densely scaly on the midvein and scatteredly scaly on the veinlets; midvein scales narrowly lanceolate, apically usually glandular, (0.8)1-2 x (0.1)0.2-0.4 mm, the margins with scattered cilia $1 / 5-1 / 3 \mathrm{x}$ the scale length; veinlet scales mixed, one type simple to pectinate, hair-like, the second type (0.4)0.6-1 x 0.05-0.1 mm, the margins with scattered cilia $1 \mathrm{x}$ the scale length, hyaline. Sori medial, usually placed distally on the segment, 4-6 pairs per segment, 3-4 sporangia per sorus. 


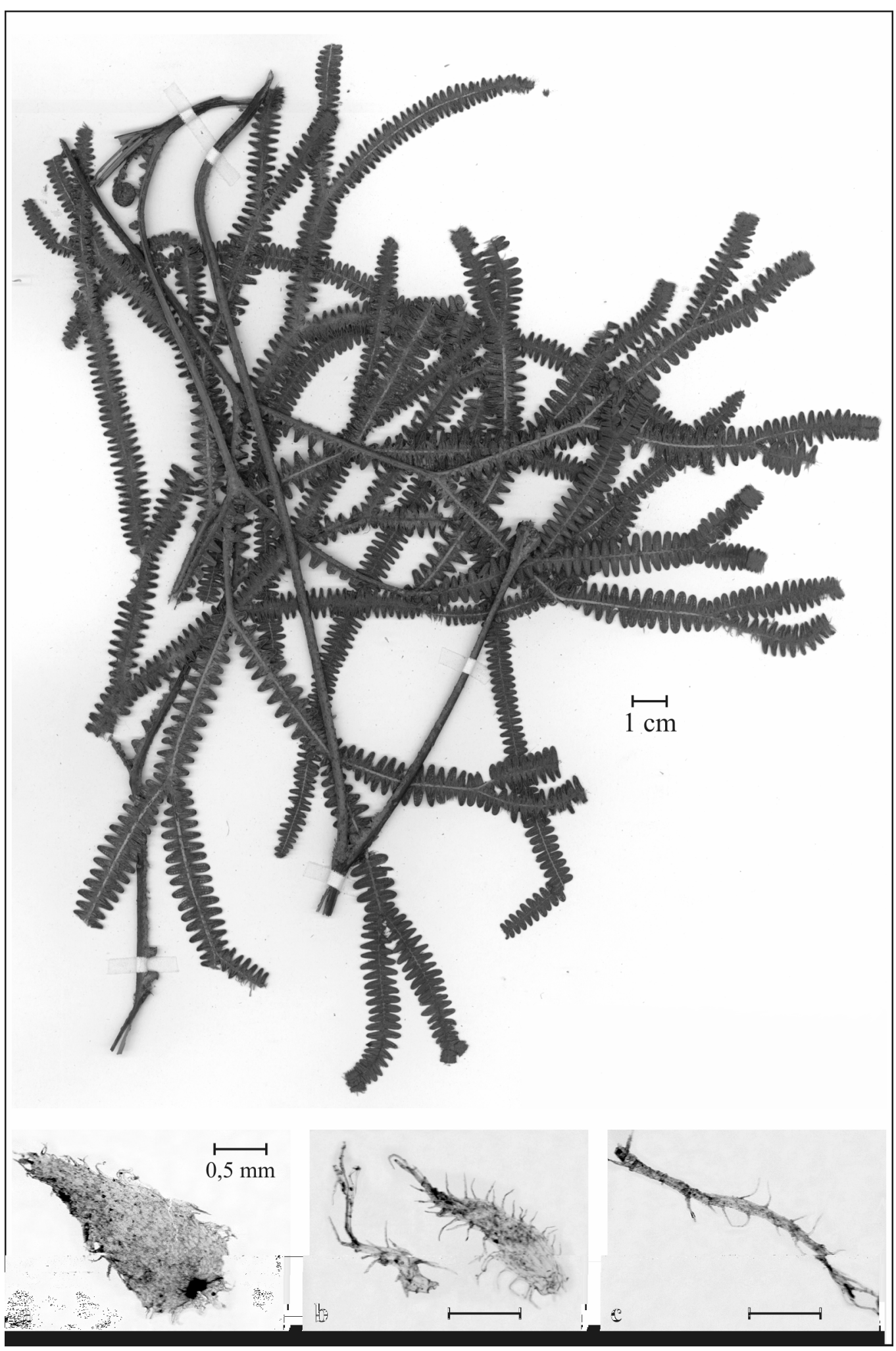

Fig. 19. Sticherus nervatus J. Gonzales sp. nov., a) abaxial axis scales; b) bud scales; c)adaxial axis scales. Kessler et al. 12113 (holotype UC). 
Distribution and ecology. Guyanan Shield in Guyana and southeastern Venezuela, and and Andes in northwestern Venezuela, Colombia, Ecuador, Peru, and Bolivia. Open habitats in humid montane forest at 1200-2800 m.

Sticherus nervatus is very similar to $S$. revolutus and is here recognized for the first time as a distinct species. It differs from $S$. revolutus by the abaxially strongly raised, nearly parallel veinlets with reduced scales, the usually 4- to 6forked, almost fully pectinate axes lacking aphlebiae, by lacking squamophores, and by the densely scaly abaxial axes, with the scales covering at least $50 \%$ of the adjacent segments. In contrast, $S$. revolutus has weakly marked, diverging, glabrous veinlets, usually 2- to 4-forked, aphlebiate axes bearing segments only on the last two axes, conspicuous squamophores, and less densely scaly abaxial axes, with the scales covering less than $50 \%$ of the adjacent segments. S. nervatus is further recognized by long 1 st axes, which generally greatly exceed the following axes in length, and by the uniform length of all axes from the 2nd onwards. Specimens from Colombia and Venezuela have relatively short abaxial axis scales that do not cover the entire segments, while in Peru and Bolivia the scales are much longer and usually cover the segments entirely. The name of the species refers to the conspicuously raised veinlets.

36. Sticherus pruinosus (Mart.) Ching, Sunyastenia 5: 284. 1940.

Mertensia pruinosa Mart., Icon. P1. Crypt. 109. 1834. Gleichenia pruinosa (Mart.) Mett., Ann. Mus. Bot. Lugd.-Bat. 1: 49. 1863. Dicranopteris pruinosa (Mart.) Maxon, Contr. U.S. Natl. Herb. 24: 29. 1922. Type. Brazil, Minas Gerais Freyreiss s.n. (holotype, M; photo, S).

Mertensia pennigera Mart., Icon. Pl. Crypt. 130, t. 59, f. 1. 1834. Gleichenia pennigera (Mart.) Moore, Index Fil. 20: 381. 1862. Dicranopteris pennigera (Mart.) Maxon, Contr. U.S. Natl. Herb. 24: 48. 1922. Sticherus penniger (Mart) Copel., Ann. Cryptog. Phytopathol. 5: 27. 1947. Type. Brazil, Minarum, in Serra de San Geraldo, Martius s.n. (holotype, M). 
Mertensia angusta Klotzssch ex Sturm, Fl. Bras. 1(2): 225. 1859. Type. Brazil, Sello s.n. (holotype ?, isotype, US).

Mertensia longipes Fée, Crypt. Vasc. Brés., II. 87. t. 105 f. 2. 1872-73. Gleichenia longipes (Fée) Christ in Schwacke, Pl. Min. Nov. 2. 35. 1900; Bull. Boiss. II. 2. 690. 1902. Type. Brasil, Brasilia, Serra do Pico, Glaziou 5235 (holotype, P).

Plants small to medium-sized. Rhizome 1.5-2.5(3.5) mm thick, dark-brown, lacking squamophores, moderately scaly, the scales narrowly lanceolate, long acuminate, (1)2.5-4 x (03)0.4-0.6 mm, reddish-brown, the margins setose, cell texture rigidsubclathrate, sometimes basally hyaline with rectangular cells. Petiole $15-50 \mathrm{~cm}$ long and (1)1.5-2.5 mm thick, castaneous, rugose. Rachis ca. (2)5-10 cm long between pinnae, brittle, subpaleaceus; aphlebiae simple, larger than the adjacent proximal internal segments. Fiddlehead ca. 2-3 mm in diameter, densely scaly, the scales orange. Bud small, ascending and opening rapidly, the scales narrowly lanceolate, long acuminate with fringed apices 0.4-0.6 mm long, (0.6)1.6-2.5 x (0.2)0.5-0.8 mm, brilliant orange to bicolorous with dark brown bases, the margins with spreading and straight cilia 1/8-1/10 $\mathrm{x}$ the scale length, cell texture stoutly-hyaline with rectangular cells. Pinnae ca. $20 \mathrm{~cm}$ long, 3-to 5-forked, all axes pectinate, $1^{\text {st }}$ and $2^{\text {nd }}$ axes the shortest, $1-2 \mathrm{~cm}$ long and 0.8-1.5 mm thick, $3^{\text {rd }}$ and $4^{\text {th }}$ axes (2)4-10(15) $\mathrm{cm}$ long and (0.3)0.5-0.7 $\mathrm{mm}$ thick, and the $5^{\text {th }}$ axis linear, 5-10 $\mathrm{cm}$ long and $0.3-0.8 \mathrm{~mm}$ thick, all axes pectinate and deeply pinnatifid, (4)5-11 mm wide with segments, with 3-4 segments per cm; adaxially with deciduous pectinate hair-like scales 1.5-3 mm long, composed of long, cylindrical to flattened cells; abaxially and laterally moderately to densely scaly, the scales covering ca. $75 \%$ of the segment surface, lanceolate, bearing a 0.5-1 mm long, pectinate apical hair, (0.7)1.7-2.5(3) x (0.2)0.4-0.5 mm, usually concolorous yellow to orange or bicolorous with darker bases, the margins with cilia $1 / 6-1 / 10 \times$ the scale length, cell texture grated-hyaline sometimes with hardened basal cells. Segments (1)2-4(6) cm long and (0.5)1-2 mm wide, triangular, the margins strongly revolute, subcoriaceous, usually whitish abaxially; veinelts diverging, slightly or not raised, glabrous; adaxially glabrous; abaxially densely scaly on the midvein, the scales long-lanceolate with a pectinate apical hair (0.3)0.6-1.5 mm long, (0.8)1-2.5 x (0.01)0.05-0.1 mm, the margins with scattered cilia 1/2-1/4 $\mathrm{x}$ the scale length. Sori supramedial, 3-4 pairs per segment, 3-4 sporangia per sorus. 
Distribution and ecology. Mountains in Surinam, Guyana, central and eastern Brazil, Ecuador, Peru, and Bolivia. Common (specially in Brazil) in open habitats in humid forest at (100?)700-2450 m.

Sticherus pruinosus is characterized by the large, oval to triangular segments with strongly revolute margins and by the abaxially densely scaly midvein with longlanceolate to hair-like scales. All the axis are pectinate and the $1^{\text {st }}$ axis is usually the shortest. It differs from $S$. revolutus by lacking squamophores, by the relative length of the axes, bearing segments on all axes, and having glabrous to scatterdly scaly axes and midveins, and from $S$. nervatus by the diverging, obscure, glabrous veinlets, the shorter overall size, and the narrowly lanceolate axis scales. Sticherus pruinosus is a rather variable species with respect to the degree of forking (3- to 5-forked), the length of the axes and the overall size of the plants, and the density of the axis and midvein scales (glabrous to moderately dense). The causes for this variation are unknown, but possible relate to environmental factors. In any case, the variation is responsible for the large number of names under which this species has been published.

37. Sticherus underwoodianus (Maxon) Nakai, Bull. Natl. Sci. Mus. 29: 31. 1950.

Dicranopteris underwoodiana Maxon, in Britton et al., N. Amer. Fl. 16: 59. 1909. Type. México, Chiapas, Ghiesbreght 271 (holotype, NY).

Plants medium-sized. Rhizome 2-3.5 mm thick, dark brown, the scales deciduous, semierect, linear-lanceolate, basally cordate, apically long-acuminate with 2 long apical setae, $1.3-3.7 \times 0.5-0.8 \mathrm{~mm}$, dark-brown, the margins with somewhat irregularly arranged setae, cell texture rigid. Petiole 1.2-2.5 mm thick and 12-40 cm long, light-castaneous to stramineus. Rachis $15-25 \mathrm{~cm}$ long between pinnae, stramineous, subpaleaceus; aphlebiae pinnatifid. Fiddlehead 2-5 $\mathrm{mm}$ in diameter, densely scaly, matted, the scales orange. Bud small to medium-sized, appressed, the scales linear-lanceolate, basally subtruncate, apically cilia 2-3 mm long, 0.6-1.3(3) x $0.1-0.5(0.6) \mathrm{mm}$, basally $10-15$ cell rows wide, golden-orange to bicolorous with darker bases, the margins with numerous and straight cilia 1/7-1/4 x the scale length, 
cell texture stoutly hyaline, basally semirigid, the cells rounded to hexagonal, forming a verniculose surface. Pinnae $18-40 \mathrm{~cm}$ long, 3(4)-forked, the 2 proximal axes short, opposite axes slightly unequal in length, (2)7.5-11 cm long, not pectinate or occasionally with internal segments, $3^{\text {rd }}$ axis linear-lanceolate, $28-40 \mathrm{~cm}$ long, 2-5 cm wide, deeply pinnatifid, 3-4 cm wide with segments, with 2-3 segments per cm; adaxial scales spreading, linear to fimbriate, $1-8 \times 0.07-0.1 \mathrm{~mm}$, orange to light brown (white with age), the margins with curled cilia $1 / 4 \mathrm{x}$ the scale length, cell texture hyaline with long, linear cells; abaxially and laterally with spreading scales resembling those of the bud, (0.5)1.7-4.5 $\mathrm{x}(0.1) 0.2-0.5 \mathrm{~mm}$ with apical cilia 0.3-0.7 $\mathrm{mm}$ long, further away from the bud and specially on larger axes the scales are more strongly hardened with straighter cilia. Segments linear, slightly narrowed at base, herbaceous, (4)8-15 x 1.5-2(3.5) mm, abaxially glabrous or with sparse scales; midvein scales long-fimbriate, $0.3-1 \times 0.06-0.3 \mathrm{~mm}, 3-5$ cell rows wide, orange, the margins with cilia (1/3)1/2-1(2) x the scale length, the cells well defined; abaxial surface scales star-shaped or fimbriate, dark orange; adaxially glabrous; midvein scales proximally large and well-developed but distally irregularly star-shaped. Sori medial, nested within a few fimbriate scales, (4)6-10(12) pairs per segment.

Distribution and ecology. Mountains of Mexico, Guatemala, Honduras, El Salvador, Costa Rica, and Cuba. In wet montane clouded forests, pine-oak forest, clearings, and along roadsides, often forming large colonies on stony ground, at 1600-3000 m, down to $1350 \mathrm{~m}$ on Cuba.

Sticherus underwoodianus is related to S. revolutus, as is evidenced by the general pattern of the axis, bud, and midvein scales, and both species have been much confused. S. underwoodianus, however, has apically densely fringed axis and bud scales, often basally hardened bud scales, broader midvein scales, rectangular to linear adaxial axis scales, and flat segments. Further, the $1^{\text {st }}$ axis is shorter to equal to the $2^{\text {nd }}$ in length, while in $S$. revolutus the $1^{\text {st }}$ axis is generally longer. $S$. underwoodianus may also be confused with $S$. furcatus which differs by its shorter, bicolorous bud scales, deeply pinnatifid segments, ciliate segment margins, and laxhyaline, star-shaped midvein scales. 
38. Sticherus jamaicensis (Underw.) Nakai, Bull. Natl. Sci. Mus. 29: 31. 1950.

Dicranopteris jamaicensis Underw. Bull. Torrey. Club 34: 258. 1907. Type. Jamaica, Blue Mountains, Underwood 1511 (holotype, NY).

Plants small to medium-sized. Rhizome 2-3 mm thick, dark brown, brittle, moderately scaly, the scales semierect, lanceolate, basally cordate, apically longacuminate, $3-4$ x $0.6-0.8 \mathrm{~mm}$, dark-brown, the margins setose to entire, cell texture rigid. Petiole 3-4 mm thick, 15-30 cm long subpaleaceus, light-castaneous, stramineus. Rachis 10-25 cm long between pinnae, subpaleaceus, the scales bicolorous; aphlebiae large, pinnatifid. Fiddlehead ca. $5 \mathrm{~mm}$ in diameter, densely scaly, the scales orange to bicolorous with brown bases. Bud medium-sized, appressed, the scales lanceolate, basally rounded, apically acuminate, fringed, 1.8-3.5 x 0.4-1 mm, dusty orange to bicolorous with a brown scale center, the margins with cilia ca. $1 / 7 \mathrm{x}$ the scale length, cell texture stoutly hyaline to mixed with semirigid bases, the cells square to long-hexagonal. Pinnae 10-25 cm long, axes 3- to 4-forked, $1^{\text {st }}$ axis $4.5-6 \mathrm{~cm}$ long and $1.5-2 \mathrm{~mm}$ thick, longer than the second, $2^{\text {nd }}$ axis $3.5-4.5$ $\mathrm{cm}$ long and 1-2 mm thick, shorter than or equal to the next when 4-forked, only with internal segments, $3^{\text {rd }}$ or distal axis $3.5-16 \mathrm{~cm}$ long, $4^{\text {th }}$ axis to $15 \mathrm{~cm}$ long and ca. 1 $\mathrm{mm}$ thick, narrowly lanceolate, pinnatisect to remotely pinnatisect, $2-2.5 \mathrm{~cm}$ wide; adaxial scales deciduous, narrowly lanceolate, ca. 0.6 x $0.7 \mathrm{~mm}$, opaque hyaline, orange to whitish; abaxially moderately scaly, the scales lanceolate, basally rounded, apically acuminate, narrowly fringed, 1.2-2.5 x 0.3-0.6 mm, pale orange, the margins with short, straight cilia, cell texture grated hyaline with square cells. Segments $0.8-$ 1.5 x $2.5 \mathrm{~mm}$, cylindric, laterally slightly revolute, thick-herbaceous; adaxially glabrous; abaxial surface obscurely papillose; midvein thick, sparsely scaly, the scales simple, hair-like, hyaline, whitish, occasionally the scales rectangular with fringed apices, $0.4-0.6 \times 0.1-0.2 \mathrm{~mm}$, orange, the margins with dense cilia $1 \mathrm{x}$ the scale length, cell texture grated hyaline; veinlets obscure, diverging, with scattered, acicular, whitish hair-like scales. Sori medial, not nested within scales, 8-10 pairs per segment, 3-4 sporangia per sorus. 
Distribution and ecology. Endemic to the Greater Antilles (Cuba, Jamaica, Hispaniola) where common in open habitats in humid montane forest at 1400-2000 m.

This species is very similar to $S$. underwodianus in most characters, but differs by having glabrescent midveins, simple, persistent, fibrillae on the abaxial segment surface, and sparser, shorter cilia on the abaxial axis and bud scales. In contrast, $S$. underwoodianus has moderately to densely scaly midveins, and larger, deciduous scales on the abaxial segment surfaces. Both species are certainly closely related but are geographically separated and thus best treated as distinct species.

The conspicuosly trifoliate aphlebiae and the relative length of axes resemble $S$. revolutus, but $S$. jamaicensis has lanceolate scales abaxially on the axes like $S$. underwoodianus. The trichomes on the abaxial segment surface are reminiscent of those of $S$. farinosus and S. brittonii.

39. Sticherus simplex (Desv.) Ching, Sunyatsenia 5: 285. 1940.

Mertensia simplex Desv., Dict. Sci. Nat. 62(2), t. 91.1827 ; Mém. Soc. Linn. Paris 6: 200. 1827 (diagnosis). Gleichenia simplex (Desv.) Hook., Icon. Pl., t. 92. 1837. Dicranopteris simplex (Desv.) Maxon, Contr. U.S. Natl. Herb. 24: 50. 1922. Type. Peru, collector unknown (holotype, P, US photo ex P).

Plants small. Rhizome 1.5-2 mm thick, castaneus, rugose, densely scaly, the scales lanceolate, basally cordate, apically long-acuminate with single long, thin apical seta, 2.5-4 x $1 \mathrm{~mm}$, golden-castaneus, the margins with thin setae, cell texture rigid with rectangular to linear cells. Petiole ca. $1 \mathrm{~mm}$ thick and 4.5-15 cm long, castaneous, brittle, subpaleaceus. Fiddlehead ca. $1 \mathrm{~cm}$ in diameter, densely scaly, the scales golden-orange. Pinnae simple, not forked, $20-30 \mathrm{~cm}$ long, remotely pectinate, 1-2.5 $\mathrm{cm}$ wide with segments, with ca. 3 segments per $\mathrm{cm}$, linear-truncate, apically gradually reduced; adaxially with scattered pectinate hair-like scales; abaxially densely scaly, the scales lanceolate, acuminate, usually with a single, long apical hair, 1.5-4 x 0.6-0.8 mm, golden-orange, the margins with thin and straight cilia 1/5 $\mathrm{x}$ the scale length, cell texture hyaline with well defined rectangular to irregular cells, sometimes forming a verrucose surface. Segments $5-10 \times 1.5-2.5 \mathrm{~mm}$, oblong, the 
margins chartaceous, revolute; veinlets diverging, obscure; adaxially glabrous; abaxially only scaly on the midveins, the scales linear to pectinate-acicular, $0.5-1 \mathrm{x}$ ca. $0.1 \mathrm{~mm}$, the margins with few long and unequally arranged cilia. Sori medial, not nested, 5-10 pairs per segment, 4-5 sporangia per sorus.

Distribution and ecology. High mountains of Colombia, Ecuador, and Peru. Locally common in humid páramo and shrubby habitats at 2400-4000 m.

This unmisteable species is the only species of Sticherus with simple leaves. The leaves have determinate growth but often bear large fiddleheads and then are reminiscent of unrelated Jamesonia (Pteridaceae). The scales of S. simplex are similar to those of $S$. revolutus, and this is possibly the most closely related species. There are also putative hybrids between both species (see under hybrids). The segment shape is reminiscent of $S$. jamaicensis and some specimens of that species bear midvein scales similar in size, shape, color, and texture to those of S. simplex. However, $S$. jamaicensis has divided leaves, and hair-like scales and simple papillae on the abaxial segment surface.

40. Sticherus lechleri (Mett. Ex Kuhn) Nakai, Bull. Natl. Sci. Mus. 29: 21. 1950.

Gleichenia lechleri Mett. Ex Kuhn, Linnaea 36: 167. 1869. Type. Peru, Puno, Tabina, Lechler 2040 (holotype, B).

Gleichenia leucocarpa Sodiro, Recens. Crypt. Vasc. Quit. 8. 1883. Sticherus leucocarpus (Sodiro) Nakai, Bull. Natl. Sci. Mus. 29: 21. 1950. Type. Ecuador, Pichincha, Canzacoto and San Florencio, Sodiro s.n. (Lectotype, K, US).

Gleichenia yungensis Rosenst., Repert. Spec. Nov. Regni Veg. 5: 228. 1908. Dicranopteris yungensis (Rosenst) Maxon, Contr. U.S. Natl. Herb. 24: 50. 1922. Sticherus yungensis (Rosenst.) Copel., Ann. Cryptog. Phytopathol. 5: 28. 1947. Type. Bolivia, Yungas, Unduavi, Buchtien 902 (holotype, S).

Plants small to medium-sized. Rhizome 2-3.5 mm thick, dark brown, rough, with short squamophores, moderately scaly, the scales narrowly lanceolate, long 
acuminate, (1.5)2.5-3(4) x 0.3-0.8 mm, dark brown, the margins with regularly arranged setae, cell texture rigid with rectangular cells. Petiole $1.8-3.5 \mathrm{~mm}$ thick and 20-50 cm long, dark brown to castaneous. Rachis ca. 10-30 cm long between pinnae, subpaleaceus, the scales usually brown; aphlebiae trifoliate with short segments. Fiddlehead 3-4 mm in diameter, moderately scaly, the scales dark orange. Bud small, ascending and opening rapidly, the scales triangular to lanceolate, apically with a thin, pectinate hair, (1)2.5-3(4) x 0.3-0.8 $\mathrm{mm}$, brilliant orange to brown-reddish, the margins with numerous, thin, slightly curled cilia $1 / 7 \mathrm{x}$ the scale length, cell texture grated, stoutly-hyaline with hexagonal to linear cells. Pinnae $25-35 \mathrm{~cm}$ long, axes 3to 5 -forked, $1^{\text {st }}$ axis longer than the $2^{\text {nd }}, 3.5-10 \mathrm{~cm}$ long and $1.5-2 \mathrm{~mm}$ thick, not pectinate, $2^{\text {nd }}$ axis $3-8 \mathrm{~cm}$ long and 1-1.5 $\mathrm{mm}$ thick, with reduced trifoliate aphlebiae, not pectinate, $3^{\text {rd }}$ axis $2-10(20) \mathrm{cm}$ long and 0.8-1.5 mm wide, with aphlebiae, pectinate, $4^{\text {th }}$ axis (4)13-20 cm long and ca. $1 \mathrm{~mm}$ wide when distal, (1.6)2-4.5 cm wide with segments, $5^{\text {th }}$ axis occasionally present, short-lanceolate, $10-20 \mathrm{~cm}$ long and ca. $0.8 \mathrm{~mm}$ thick, pectinate, ca. $2 \mathrm{~cm}$ wide with segments; adaxially glabrous or scaly, the scales long, narrow, (1.6)2-3 x 0.1-0.3 mm, whitish, hyaline, the margins with few cilia; abaxially and laterally moderately to densely scaly, the scales narrowly lanceolate with a long and septate apical hair, (1.5)2.5-3(4) x 0.3-0.6 mm, brilliant orange, the margins thin, with few, straight cilia, the cells hexagonal and narrow to basally irregular. Segments herbaceous (usually with scaly midveins) to slightly chartaceous (usually glabrous and glaucous), the first proximal internal segments usually covering the bud, $0.8-1.6(2) \mathrm{cm}$ long and $1.5-3 \mathrm{~mm}$ wide; veinlets slightly raised abaxially; adaxially glabrous; abaxially glabrous or scaly on the midvein; midvein scales linear with one or two apical cilia, 0.3-1 x 0.05-0.1 mm, ca. 2-3 irregular cell rows wide, the margins with few cilia 1/2-1 $\mathrm{x}$ the scale length; scales of veinlets and around sori fimbriate to pectinate, hair-like, brilliantly orange to dusty. Sori medial, not reaching segment apex, on a receptacle with septate, short hairs that are only visible when the sori are missing, (4)7-15 sori, 3-6 sporangia per sorus.

Distribution and ecology. Andes from southern Colombia (Putumayo) to Ecuador, Peru, and Bolivia. Common in the south, uncommon in the north, in humid montane forest, along roadside, and on river banks, at 1100-3300 m. 
Sticherus lechleri is characterized by its large trimerous aphlebiae on the lower two axes that otherwise lack segments, flat segments, sparsely scaly abaxial axes with lanceolate, long-acuminate, orange, hyaline scales, glabrous or very sparsely scaly midveins with linear scales, stoutly-hyaline, usually basally hardened bud scales with short cilia or setae, and sometimes simple fibrillae on the veinlets. It may be confused with $S$. rubiginosus which is of similar size and has similarly shaped axis scales, but $S$. lechleri has squamophores, and axis scales that are never hardened and have scattered, short cilia. Further, the axes are more widely spreading, and even somewhat arching in S. lechleri, while in S. rubiginosus they are straight. Another similar species is $S$. revolutus, which has revolute segment margins, densely scaly midveins, and orange bud scales lacking hardened parts.

There is quite a bit of morphological variability within S. lechleri, presumably related to environmental conditions. Specimens growing inside forests are more slender and have more dense midvein scales, while those of sunny sites are stouter, have glabrous midveins and larger aphlebiae, and are often conspicuously glaucuous underneath.

41. Sticherus boliviensis (Maxon \& C.V. Morton) J. Gonzales comb. nov.

Dicranopteris boliviensis Maxon \& C.V. Morton, Bull. Torrey Bot. Club.66: 44. 1939. Type. Bolivia, La Paz, Yungas, Cocopunco, 3050 m, Tate, G.H.H. 351 (holotype, NY; isotype, US).

Plants small, slender. Rhizome 2-2.5 mm thick, dark brown to reddish, rugose with squamophores to $3 \mathrm{~mm}$ long, moderately to densely scaly, the scales semierect, triangular to lanceolate, acuminate, $2-5 \times 0.4-0.9 \mathrm{~mm}$, dark brown, the margins setose, cell texture rigid with linear cells. Petiole 1.8-3 mm thick, ca. 20-50 cm long, castaneous to orange, brittle. Rachis ca. 10-25 cm long, subpaleaceous, the scales usually brown to whitish; aphlebiae absent. Fiddlehead ca. 4-6 $\mathrm{mm}$ in diameter, densely scaly, the scales spreading, dusty orange to bicolorous. Bud large, ascending and opening rapidly, the scales, triangular to lanceolate, (1)2.5-5 x 0.3-0.8 mm, bicolorous, dusty orange with dark brown bases or completely blackish with pale margins, the margins with numerous thin, slightly curled cilia $1 / 4 \mathrm{x}$ the scale length, 
cell texture stoutly hyaline to mixed with semirigid bases and centers or wholly darkened, the cells hexagonal to linear, forming an ill-defined surface. Pinnae 15-45 cm long, axes (2-)3- to 4-(5-) forked, $1^{\text {st }}$ axis 2.5-5(10) $\mathrm{cm}$ long and 1-2 $\mathrm{mm}$ wide, not pectinate, $2^{\text {nd }}$ axis (1.6)3-5(18) $\mathrm{cm}$ long and 0.5-1.5 mm thick, occasionally with internal segments, ca. $1.7 \mathrm{~cm}$ wide with segments, $3^{\text {rd }}$ or distal axis, $3-16 \mathrm{~cm}$ long and 0.7-1.5 mm thick, an occasional $4^{\text {th }}$ and distal axis narrowly-lanceolate, truncate, 15-20 $\mathrm{mm}$ long and 0.5-0.8 $\mathrm{mm}$ thick, pinnatisect, 1.2-2.5 $\mathrm{cm}$ wide with segments, with 3-3.5 segments per $\mathrm{cm}$, pectinate axes lacking proximal internal segments; adaxial scales mixed, one type rectangular, 0.1-0.4(0.6) x $0.05-0.1 \mathrm{~mm}$, the second type linear, 1-2.5 x (0.05)0.1-0.2 mm, both scale types apically fringed, orangehyaline, cell texture semirigid to hyaline; abaxially and laterally moderately to densely scaly, the scales triangular to lanceolate with long-fringed apices, (1)2-2.5(3) x 0.2-0.4(0.6) $\mathrm{mm}$, orange to bicolorous, speckled with a mixture of rigid and hyaline parts, the margins straight with irregularly arranged cilia $1 / 4 \mathrm{x}$ the scale length.

Segments oblong to triangular, pectinate; veinlets abaxially raised; segments pectinate, (7)10-14 x $2 \mathrm{~mm}$; adaxially glabrous; midvein scales dense, rectangular to linear, wavy, (0.3)0.6-1.4 x ca. $0.1 \mathrm{~mm}$, ca. 2 cell rows wide, orange to opaque, the margins with few, thick cilia 1/2-1 x the scale length, semi-hyaline; veinlets abaxially moderately scaly, the scales fimbriate, orange-dusty. Sori medial, not reaching segment apex, not nested within scales, 3-6 pairs per segment, 3 sporangia per sorus.

Distribution and ecology. Common in humid montane forest at (1500)2200-3300 m in southernmost Peru (Puno) and Bolivia.

Sticherus boliviensis is characterized by its tiny, round aphlebiae, deeply pinnatifid segments, lanceolate, copiously ciliate axis and bud scales with a basal hardening pattern always leaving the margins hyaline, and specially by the linear, wavy, 1- to 2-cells wide midevein scales with a few cilia. It has been confused Sticherus rubiginosus and $S$. revolutus because these have a similar habitat and size, and linear midvein scales. However, S. rubiginosus has inframedial sori, strongly raised veinlets, larger, trimerous aphlebiae, and setose axis and bud scales with a marginal hardeining pattern, while $S$. revolutus has shorter, more rounded segments, conspicuous aphlebiae, hair-like scales adaxially on the axes, and long-acuminate, 
lanceolate, short-ciliate axis and bud scales without hardening. S. boliviensis may also be confused with $S$. peruvianus which has a similar shape of the last axes and similar overall size, but the latter species has trimerous aphlebiae and lanceolate midvein scales.

42. Sticherus longipinnatus (Hook.) Ching, Sunyastenia 5: 238. 1940

Gleichenia longipinnata Hook., Sp. Fil. 1: 9. 1844. Mertensia longipinnata (Hook.) Klotzsch, Linnaea 18: 537. 1844. Dicranopteris longipinnata (Hook.) Maxon, Contr. U.S. Natl. Herb. 24: 48. 1922. Type. Surinam, Hostmann 238 (holotype BM; isotype K, US)

Plants medium-sized to large, slender. Rhizome $1.5-5 \mathrm{~mm}$ thick, densely scaly, the scales falcate, long-lanceolate, acuminate, (2)3-7 x 0.4-0.6 mm, light brown to orange, the margins setose, cell texture semirigid with linear cells. Petiole 3-7 mm thick and 15->50 cm long, castaneous, brittle, subpaleaceus. Rachis ca. $30 \mathrm{~cm}$ long between pinnae, the scales semirigid; aphlebiae pinnatifid. Fiddlehead ca. $1 \mathrm{~cm}$ in diameter, matted, moderately scaly, the scales cinnamon to dark brown. Bud large, narrow, ascending and opening rapidly, the scales linear-lanceolate, basally rounded to truncate, apically with a long, usually complex hair, (2)5-8 x (0.2)0.4-0.8 mm, dark brown to cinnamon, the margins with short setae, cell texture semirigidsubclathrate with rounded to hexagonal cells. Pinnae to $>50 \mathrm{~cm}$ long, 2- to 3-forked, $1^{\text {st }}$ axis (1.5)2-3 cm long and 1.5-3 mm thick, pectinate, $2^{\text {nd }}$ axis long-lanceolate, usually the distal, (15)35-60(100) cm long and 1-2 mm thick, pinnatisect to remotely pinnatisect, (5)8-10 cm wide with segments, with ca. 2-2.5 segments per cm; scales adaxially mixed, one type rectangular to linear, $1-3 \mathrm{x}$ ca. $0.1 \mathrm{~mm}$, the second type long-lanceolate, $0.2-0.8 \times 0.1 \mathrm{~mm}$ with a $1-1.5 \mathrm{~mm}$ long apex, both scale types semirigid; abaxially and laterally moderately to densely scaly, the scales linearlanceolate to filiform or hastate, (1)3-5(8) x 0.1-0.3 mm, shiny-orange, the margins with scattered cilia or setae ca. $1 / 6 \mathrm{x}$ the scale length, cell texture semiclathrate with hexagonal cells, sometimes marginally rigid. Segments (1)3-4.5(6) x 2-4 mm, narrowly linear, subchartaceous, the margins revolute, ciliate, the first proximal segment longer than the adjacent, overlapping; adaxially glabrous; abaxially scaly on the midvein, veinlets and margins; midvein scales hastate, $0.2-0.8 \times 0.1-0.3 \mathrm{~mm}$ with 
a 0.1-0.4 mm long apex, orange to brown cinnamon, cell texture rigid to semiclathrate; veinlet scales reduced, long-lanceolate, hyaline; marginal scales starshaped, whitish, hyaline. Sori inframedial, restricted to the segment centers, 15-30 pairs per segment, 3-5 sporangia per sorus.

Distribution and ecology. Surinam, Guyana, northern Brazil, Ecuador. Rather uncommon along roadsides and in other open habitats in humid forest at 600-1100 $\mathrm{m}$.

Sticherus longipinnatus is a distinctive, large species with very short $1^{\text {st }}$ axes, slender, trimerous aphlebiae, narrowly lanceolate, long-acuminate, cinnamon abaxial axis and bud scales, pinnatisect segments, anchor-shaped midvein scales with two lateral cilia and a long apical cilium, and abaxial segment surfaces with thin, moderately raised veinlets and very scattered, star-shaped scales. The scales of the segment surface sometimes protrude beyond the segment margins and these then appear to be ciliate. The size and coloration of this species are reminiscent of $S$. chocoensis, but that has a densely scaly abaxial segment surface and overall broader, more opaque scales.

43. Sticherus nudus (Moritz) Nakai, Bull. Natl. Sci. Mus. 29: 23. 1950.

Mertensia nuda Moritz, Akad. Wiss. Wien, Math.- Naturwiss. K1., Denkschr. 17 (2): 28, t 1, f 1-4, 1859. Type. Venezuela, Caracas „In sylvis reg. subalp. loc. Aperetis“, 1856, Tovar \& Moritz 452 (holotype, W).

Plants medium-sized. Rhizome 3-4 mm thick, dark brown, the scales deciduous, ovate-lanceolate, $2-2.5 \times 0.8 \mathrm{~mm}$, dark brown, the margins setose, cell texture rigid to semiclathate with rectangular cells. Petiole 2.5-3(4) mm thick and more than 30 cm long, castaneous-orange, brittle. Rachis ca. (9)15-30(40) cm long between pinnae, deciduously scaly. Fiddlehead ca. 3-5 mm in diameter, loosely scaly, green or dark green. Bud small, appressed, drop-shaped, the scales ovate-lanceolate, basally rounded, apically cuspidate, (0.8)1-2(3) x 0.5-1.2 mm, orange to bicolorous with orange bases, the margins entire to ciliate with thin and straight cilia $1 / 8 \mathrm{x}$ the scale length, cell texture hyaline with square to rounded cells. Pinnae $35-45 \mathrm{~cm}$ long, axes 
3 - to 4 -forked, $1^{\text {st }}$ axis usually longer than the $2^{\text {nd }}, 4-6(8) \mathrm{cm}$ long and $1.2-2 \mathrm{~mm}$ thick, not pectinate; $2^{\text {nd }}$ axis $3-4(5) \mathrm{cm}$ long and 1-1.5 mm thick, not pectinate or occasionally with scattered segments, $1-6 \mathrm{~cm}$ wide with segments, $3^{\text {rd }}$ and distal axis ca. 6-25(35) $\mathrm{cm}$ long and 1-1.5 mm thick, pectinate, 3-5 cm wide with segments, with ca. 2 segments per $\mathrm{cm}$, occasionally a $4^{\text {th }}$ axis present, lanceolate, basally truncate, 15-25 cm long and 1-1.2 mm thick, 2-4 cm wide with segments, 2.5-3 segment per $\mathrm{cm}$, last axis pinnatisect, lacking proximal internal segments on the first 0.5-2 cm; adaxial scales deciduous, ovate, highly reduced, $0.2 \times 0.04-0.06 \mathrm{~mm}$, whitish, the margins with irregularly arranged, long cilia, hyaline; abaxial scales lateral, scattered, rounded to ovate-lanceolate, apically tufted and sometimes glandular, (0.4)0.9-1(1.7) x (0.2)0.4-0.8 mm, orange, the margins hyaline, entire or with a few cilia $1 / 5-1 / 3 \times$ the scale length, cell texture hyaline with square to rounded cells. Segments (0.6)1.5-3 cm long and (1.5)2-3.5 mm wide, oblong, pinnatisect, the margins chartaceus undulate; veinlets abaxially raised; midvein abaxially scaly, the scales gradually reduced, proximally ovate with usually glandular apices, ca. $0.3 \mathrm{~mm}$ in diameter, distally apically long-linear, ca. $1.5 \mathrm{~mm}$ long; abaxial surface glabrous or scaly, the scales scattered, highly reduced, arachnoid, orange to whitish, the margins entire or with cilia 1/3-1/2 x the scale length, hyaline. Sori inframedial not reaching segment apex, nested within arachnoid scales, 9-17 pairs per segment, 4-5-6 sporangia per sorus.

Distribution and ecology. Andes in Colombia and Venezuela. Forms dense colonies in open habitats in montane forest at 1600-2700 m.

Sticherus nudus belongs to a group of four confusingly similar Mesoamerican and Andean species, together with $S$. brevitomentosus, S. ovatus, and S. pteridellus. These species all have ovate segments, unpectinate proximal axes, pinnatisect, usually flat segments, generally rather sparsely scaly axes, ovate-lanceolate to ovate scales that appear papyraceous and dusty whitish to dark when dry, and lack aphlebiae. The main characters separating the species are listed in Table $\mathrm{x}$.

Sticherus nudus is characterized by abaxially protruding last axes, 1 staxes longer than the $2^{\text {nd }}$, arched axes, petioles and rachises much thicker than the pinna axes, thick rhizomes with scattered, rigid scales, cartilaginous, undulate segment margins, abaxially glabrous segments with raised, parallel veinlets, sparse, reduced, 
mixed rounded and linear scales restricted to the midvein and sometimes around the inframedial sori, and ovate to rounded axis and bud scales with usually glandular apices. The arched axes are reminiscent of $S$. aurantiacus and $S$. tepuiensis, but these species are densely scaly with narrowly lanceolate scales.

Tab. 2. Comparative characters of $S$. nudus, S. brevitomentosus, S. ovatus, and $S$. pteridellus.

\begin{tabular}{|c|c|c|c|c|}
\hline & S. nudus & S. brevitomentosus & S. ovatus & S. pteridellus \\
\hline Texture of bud scales & $\begin{array}{l}\text { hyaline, cells round, } \\
\text { short }\end{array}$ & $\begin{array}{l}\text { stoutly hyaline, cells } \\
\text { square to hexagonal }\end{array}$ & $\begin{array}{l}\text { hyaline, cells } \\
\text { rounded }\end{array}$ & $\begin{array}{l}\text { stoutly hyaline with } \\
\text { semirigid bases, cells } \\
\text { square }\end{array}$ \\
\hline Shape of bud scales & ovate & ovate-lanceolate & irregularly ovate & ovate-lanceolate \\
\hline Midvein scales & $\begin{array}{l}\text { reduced, lanceolate to } \\
\text { linear }\end{array}$ & reduced, lancelate & ovate, glandular & $\begin{array}{l}\text { reduced, lanceolate to } \\
\text { star-shaped }\end{array}$ \\
\hline Segment size (mm) & $15-30 \times 2-3.5$ & $10-22 \times 2.5-4$ & $15-30 \times 2-3.5$ & $15-20 \times 2-2.5$ \\
\hline $\begin{array}{l}\text { Abaxial segment } \\
\text { surface }\end{array}$ & glabrous & densely scaly & densely scaly & $\begin{array}{l}\text { glabrous to scatteredly } \\
\text { fibrous and } \\
\text { papiliaceous }\end{array}$ \\
\hline Veinlets & thin, raised & thin, moderately raised & thick, raised, dark & obscure \\
\hline $\begin{array}{l}\text { Rhizome diameter } \\
(\mathrm{mm})\end{array}$ & $3-4$ & $2-5$ & $2.5-3.5$ & $1.5-2$ \\
\hline Rhizom scales & $\begin{array}{l}\text { lanceolate, semirigid } \\
\text { to semiclathrate, } \\
\text { margins setose }\end{array}$ & $\begin{array}{l}\text { lanceolate, semirigid, } \\
\text { margins setose }\end{array}$ & ovate, hyaline, enti & $\begin{array}{l}\text { eovate, stoutly hyaline, } \\
\text { entire }\end{array}$ \\
\hline Axes & $\begin{array}{l}\text { long, arching, 2- to } 3 \text { - } \\
\text { forked }\end{array}$ & $\begin{array}{l}\text { - long, arching, 2- to 3- } \\
\text { forked }\end{array}$ & $\begin{array}{l}\text { long, arching, 2- } \\
\text { forked }\end{array}$ & $\begin{array}{l}\text { short, straight, 3- to } 4- \\
\text { forked }\end{array}$ \\
\hline Distribution & $\begin{array}{l}\text { Venezuela to } \\
\text { Colombia }\end{array}$ & Venezuela to Bolivia & $\begin{array}{l}\text { Venezuela to } \\
\text { Ecuador }\end{array}$ & Nicaragua, Costa Rica \\
\hline
\end{tabular}


44. Sticherus ovatus J. Gonzales sp. nov.

Type. Colombia, Santander, Páramo de Fontibon, Pamplona, 2400 m, 25 Feb 1939, Alston 7279 (holotype, BM; isotypes, COL, MO).

Affinis S. bifido, differt statura minori, pinnis brevioribus latioribusque, squamis brevioribus, distincte rotundatis, ciliis brevioribus vel fere nullis (praecipue in squamis costae).

Plants small to medium-sized. Rhizome 2.5-3.5 mm in diameter, brittle, the scales somewhat deciduous, ovate, ca. $2 \times 1 \mathrm{~mm}$, orange, the margins entire, cell texture hyaline with rounded cells. Petiole $2.5-3.5 \mathrm{~mm}$ thick and ca. $30 \mathrm{~cm}$ long, dark brown, brittle. Rachis ca. 10-20 cm long between pinnae, subpaleaceous, the scales ovate, bicolorous whitish to orange; aphlebiae absent. Fiddlehead 2-3 $\mathrm{mm}$ in diameter, sparsely scaly, the scales opaque brown. Bud small, rounded and closed, the scales ovate to rounded, apically erose or glandular, $1.5-3.2 \times 0.8-1.5 \mathrm{~mm}$, orange to slightly bicolorous with dark orange bases, the margins with delicate, straight to contorted cilia 1/5-1/4 x the scale length, cell texture grated hyaline with usually stoutly hyaline bases, the cells rounded with thickened cell walls at the scale bases. Pinnae ca.15-30 cm long, 2- to 3-forked, when 3-forked the $1^{\text {st }}$ axis usually longer than the second, $1^{\text {st }}$ axis $3-6 \mathrm{~cm}$ long and $1.5-2 \mathrm{~mm}$ thick, not pectinate, opposite $2^{\text {nd }}$ axes usually of unequal length, the shorter one $2.5-5 \mathrm{~cm}$ long and 1-2 mm thick, scatteredly pectinate, the longer and the $3^{\text {rd }}$ axes lanceolate to long-triangular, 20$30(40) \mathrm{cm}$ long and 1-1.5 mm thick, pectinate but lacking proximal internal segments on the first $0.5-2.5 \mathrm{~cm}, 2.5-4 \mathrm{~cm}$ wide with segments, with 2-3 segments per $\mathrm{cm}$; scales adaxially mixed, one type rectangular, ca. $0.5 \times 0.2 \mathrm{~mm}$, the margins with cilia $1 / 2-1 \times$ the scale length, the second type fibrillose, both scale types completely hyaline, whitish; abaxially and laterally moderately scaly, the scales ovate to rounded, 0.6-2 x (0.2) 0.4-0.8 mm, orange, the margins hyaline with delicate cilia, cell texture hyaline with rounded to irregular cells. Segments $1.5-3 \mathrm{~mm}$ x 2-3.5 mm, long-ovate, subchartaceous, the margins slightly revolute, proximal internal segments usually not overlapping; veinlets parallel, dark, abaxially raised; adaxially glabrous; 
abaxial midvein scales ovate to rounded, apically usually glandular, 0.3-1.5 x 0.3-0.6 $\mathrm{mm}$, orange to whitish, the margins with few, delicate cilia $1 / 2-1 \mathrm{x}$ the scale length,

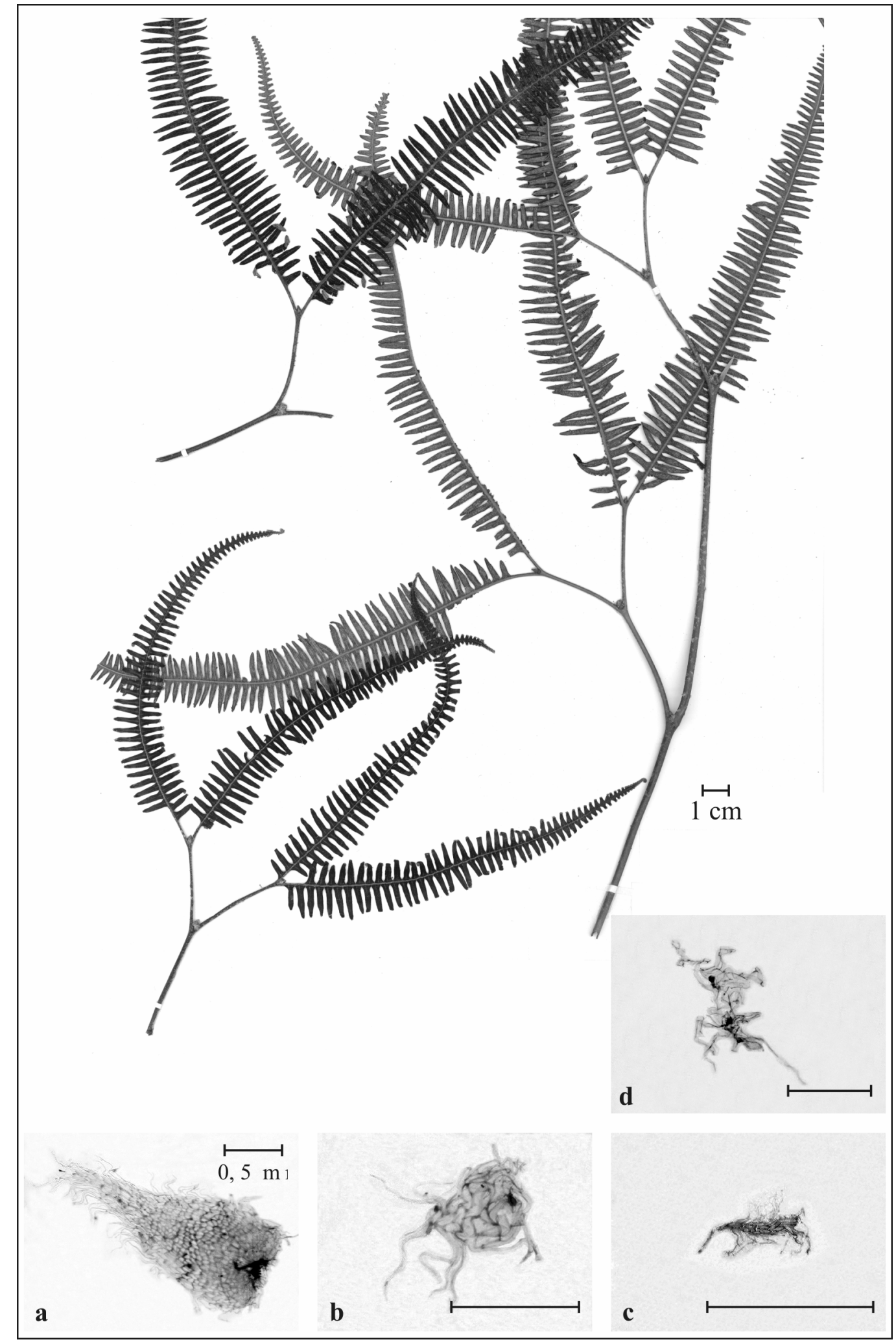

Fig. 20. Sticherus ovatus J. Gonzales sp. nov., a) abaxial axis scales, b) midvein scales; c) adaxial axis scales; d) arachnoide scales. Alston 7279 (holotype, BM). 
cell texture grated hyaline with rounded to irregular cells; abaxial scales on the surface between the veinlets arachnoid. Sori inframedial, restricted to the segment centers, nested within arachnoid scales, 9-15 pairs per segment, 3-4 sporangia per sorus.

Distribution and ecology. Mountains of northern Venezuela, Colombia, and Ecuador. Locally common in open habitats in humid montane forest at ca. 1500-2700 $\mathrm{m}$.

Sticherus ovatus is characterized by lacking aphlebiae and internal proximal segments, in having lanceolate segments with truncate bases and often almost conform apices, and in bearing ovate scales (hence the species name) with a lax, hyaline texture and rounded cells. Specially on the midvein scales, this gives a papyraceaous appearance to the indument. The bud and midvein scales bear glandular apices. Sometimes the bud scales are bicolorous with a dark base, but this is based only on the darker coloration of the cell walls and not (as is usually the case in Sticherus) on a thickening of the walls.

Because of its dense abaxial segment indument and due to lacking proximal internal segments, Sticherus ovatus is most similar to S. bifidus, and previous workers identified the respective collections as that species. However, there are some clear, consistent differences between these taxa. Sticherus ovatus is shorter overall, has shorter, more rounded scales with shorter cilia (specially on the midvein scales), and has shorter, relatively broader pinnae. Sticherus ovatus is probably most closely related to $S$. nudus, but that species completely lacks scales abaxially on the segments, has lanceolate, rigid to subclathrate rhizome scales, and has the sori restricted to the central part of segments.

45. Sticherus brevitomentosus Østergaard \& B. Øllgaard, Flora of Ecuador 66: 132. 2001. Type. Ecuador. Zamora-Chinchipe, Yangana-Valladolid, km 29, 2580 m, Østergaard A. E. 10728 (holotype, QCA; isotypes, AAU).

Plants medium-sized, slender. Rhizome 2-5 mm thick, dark brown, the scales deciduous, narrowly lanceolate, $1.5-3.5 \times$ x 0.3-0.5 mm, dark brown, the margins setose, cell texture mixed, rigid with hyaline parts, the cells rectangular. Petiole ca. 
$30 \mathrm{~cm}$ long and ca. $3 \mathrm{~mm}$ thick, castaneous, brittle. Rachis ca. $20 \mathrm{~cm}$ long between pinnae, sparsely scaly; aphlebiae absent. Fiddlehead ca. $0.5 \mathrm{~cm}$ in diameter, densely scaly, the scales orange to brown. Bud small, closed, the scales lanceolate to longlanceolate, 1.2-2 $\times 0.5-0.8 \mathrm{~mm}$, orange to bicolorous with slightly darker bases, the margins with abundant, irregularly arranged cilia $1 / 5 \mathrm{x}$ the scale length, cell texture hyaline to stoutly hyaline or with rigid bases, the cells rounded to rectangular. Pinnae ca. $40 \mathrm{~cm}$ long, 2- to 3 -forked, $1^{\text {st }}$ and $2^{\text {nd }}$ axis of similar length, (2)3.5-8 cm long and 1-2 mm thick, not pectinate but sometimes $2^{\text {nd }}$ axis scatteredly pectinate, $3^{\text {rd }}$ axis linear-lanceolate, basally truncate, $20-40 \mathrm{~cm}$ long and $1-1.5 \mathrm{~mm}$ thick, pinnatisect, 2.5-4 cm wide with segments, with 2-3 segments per $\mathrm{cm}$, lacking proximal internal segments on the first $0.5-2.5 \mathrm{~cm}$; adaxial scales irregularly shaped, (0.1)0.2-1 x 0.05$0.1 \mathrm{~mm}$, whitish, the margins with cilia 1-3 x the scale length, hyaline; abaxially and laterally moderately densely scaly, the scales lanceolate with irregular apices, 0.6-1.8 x 0.4-0.8 mm, orange and sometimes speckled with brown dots, the margins irregularly ciliate, cell texture hyaline, sometimes with scattered dark cells, the cells rounded to irregular. Segments 1-2.2 x 2.5-4 mm, long-oval, subchartaceous, the margins slightly revolute, proximal internal segments gradually or abruptly decreasing in length; veinlets parallel, dark, abaxially raised; adaxially glabrous; abaxially densely scaly on midvein, veinlets, and surface; midvein scales narrowly triangular to acicular with a short apical hair, ca. $2 \times 0.1 \mathrm{~mm}$, orange, the margins with few and thin cilia $1 / 4 \mathrm{x}$ the scale length, cell texture hyaline with irregular cells; veinlet and surface scales arachnoid, orange, the margins with few cilia 1-2 $x$ the scale length, cell texture hyaline. Sori inframedial, restricted to the segment center, densely nested within arachnoid scales, 9-20 pairs per segment, 4-5 sporangia per sorus.

Distribution and ecology. Andes from Venezuela to Bolivia. Apparently rather uncommon and local along forest edges and road banks in humid montane forest at 600-2900 m.

This species was described as distinct from S. bifidus by Østergaard \& Øllgaard (2001) because it has arched, unpectinate proximal axes, bicolorous axis and bud scales, and relatively broader and shorter, less tapering segments with usually flat margins and rounded apices. Among the species recognized here, $S$. 
brevitomentosus is most similar to $S$. ovatus due to the segments restricted to the distal axes, lanceolate last axes with truncate bases, and the densely scaly abaxial segment surface with arachnoid scales, but $S$. brevitomentosus has lanceolate, rigid rhizome scales, ciliate, more lanceolate abaxial axis and midvein scales, and thinner, less strongly raised veinlets. $S$. brevitomentosus may also be confused with $S$. aurantiacus because both have arched, unpectinate proximal axes, but $S$. aurantiacus has narrowly lanceolate abaxial axis and bud scales, reduced proximal internal segments, more orangish scale coloration, and usually more revolute segment margins. Other similar species are S. nudus and S. pteridellus (see Tab. x).

46. Sticherus pteridellus (H. Christ) Copel., Gen. Fil., Ann. Cryptog. Phytopathol. 5: 28.1947.

Gleichenia pteridella H. Christ, Bull. Herb. Boissier sér. 2, 6: 284, 1906.

Dicranopteris pteridella (H. Christ) Underw. Bull. Torrey Bot. Club 34: 260. 1907. Type. Costa Rica, Werklé s.n. (holotype, P, photo BM).

Plants medium-sized to large, slender. Rhizome 1.5-2 mm thick, dark brown, the scales deciduous, lanceolate, $1.5-2 \times 0.5-0.8 \mathrm{~mm}$, brown to orange, the margins entire to apically setose, cell texture semirigid with rectangular cells. Petiole over $60 \mathrm{~cm}$ long and 0.4-0.7 mm thick, castaneous, subpaleaceus. Rachis ca. 15-25 cm long between pinnae, the scales usually dusty whitish to blackish; aphlebiae absent. Fiddlehead ca. $4 \mathrm{~mm}$ in diameter, green, turning brown, loosely scaly. Bud large, pyramidal, closed, the scales ovate to oblong, basally rounded to cordate, $1.5-2.5 \mathrm{x}$ 0.5-1 mm, the margins membranaceous with short, thick cilia $1 / 8 \mathrm{x}$ the scale length, cell texture hyaline with dark brown bases, the cells rectangular to irregular, forming a diffuse pattern, sometimes including darkened cells. Pinnae ca. $35 \mathrm{~cm}$ long, (2)3to 4 -forked, $1^{\text {st }}$ and $2^{\text {nd }}$ axes short, not pectinate, $2^{\text {nd }}$ axis usually shorter than the $1^{\text {st }}$, $3-5 \mathrm{~cm}$ long and $1.5-2 \mathrm{~mm}$ thick, $2^{\text {nd }}$ axis $2-3 \mathrm{~cm}$ long and $1-1.5 \mathrm{~mm}$ thick, $3^{\text {rd }}$ or last axes lanceolate, basally truncate, $15-20 \mathrm{~cm}$ long and $1 \mathrm{~mm}$ thick, with lateral membranaceus projections, pinnatisect, lacking proximal segments on the first 0.5-2 $\mathrm{cm}, 2.5-4.5 \mathrm{~cm}$ wide with segments, with 3 segments per $\mathrm{cm}$; scales adaxially linear, 1.5-2 x 0.1-0.2 mm, 4-6 cell rows wide, whitish, the margins irregularly ciliate, cell texture hyaline, the cells rectangular; abaxially and laterally moderately scaly, the 
scales ovate with an apical hair, $0.5-2 \times 0.4-0.8 \mathrm{~mm}$, brilliant orange to bicolorous, opaque at the scale base and center, the margins with irregular short cilia. Segments linear-oval, subchartaceous, proximal internal segments overlapping, 1.5-2 x 2-2.5 $\mathrm{mm}$, the margins chartaceous, usually revolute; veinlets, raised, parallel; adaxially glabrous; abaxially with scales on the midvein, fimbriate and/or papillate on the surface; midvein scales triangular with an apical hair ca. $0.6 \mathrm{~mm}$ long, 0.2-0.4 x ca. $0.2 \mathrm{~mm}$, hyaline to brilliant orange, the margins hyaline, irregularly ciliate; surface scales reduced or fimbriate, hyaline. Sori medial to inframedial, not reaching segment apex, ca. 5-10 pairs per segment, (3)4-6 sporangia per sorus.

Distribution and ecology. Mountains of Nicaragua and Costa Rica. Locally common in open habitats in humid montane forest at 1100-2100 m.

Sticherus pteridellus is characterized by having the $1^{\text {st }}$ axes as long as to slightly longer than the $2^{\text {nd }}$, thin rhizomes with scattered, ovate, stoutly hyaline scales, protruding abaxial axes with scattered, dusty-whitish scales, lanceolate-ovate, stoutly hyaline, usually basally slightly hardened bud scales with short marginal cilia and a ciliate or glandular apex, narrowly revolute segment margins, irregularly rounded midvein scales, obscure veinlets with sparse, simple, fibrillae, and sometimes papillae on the segment surface. It differs from $S$. nudus by the more slender axes, shorter, straight $1^{\text {st }}$ axes, narrower segments, fibrillose and/or papillate segments, and thinner rhizomes with hyaline, ovate scales.

47. Sticherus hypoleucus (Sodiro) Copel., Ann. Cryptog. Phytopathol. 5: 28, 1947.

Gleichenia hypoleuca Sodiro, Recens. Crypt. Vasc. Quit. 8. 1883. Type. Ecuador, Pichincha, Sodiro s.n. (hololectotype, SI, selected by R.C. Moran, Flora Mesoamericana $1: 60.1995$; isolectotype, K)

Gleichenia lehmannii Hieron., Bot. Jahrb. Syst. 34: 562. 1905. Dicranopteris lehmannii (Hieron.) Maxon, Proc. Biol. Soc. Wash. 43: 83. 1930. Sticherus lehmannii (Hieron.) Nakai, Bull. Natl. Sci. Mus. 29: 21. 1950. Type. Colombia, Popayán, Lehmann 6963 (holotype, ?; isotype, US). 
Gleichenia nitidula Rosenst., Repert. Spec. Nov. Regni Veg. 10: 275. 1912. Sticherus nitidulus (Rosenst.) Copel., Ann. Cryptog. Phytopathol. 5: 28. 1947. Dicranopteris nitidula (Rosenst.) Suess. Ex Losch, Mit. Bot. Staatssamml. München1: 24. 1950. Type. Costa Rica, Alajuela, San Carlos-Buena Vista, Brade 503 (Holotype, S; isotype, US).

Plants small to medium-sized, slender. Rhizome 1-2 mm thick, dark brown, sparsely scaly, the scales lanceolate, basally rounded, acuminate, (1.2)2-3 x 0.4-0.6 mm, dark brown, the margins dentate, cell texture rigid with linear cells. Petiole ca. (8)20-50 $\mathrm{cm}$ long and 1-2 mm thick, castaneous to beige, sometimes brittle. Rachis $15-50 \mathrm{~cm}$ long between pinnae, brittle, deciduously scaly; aphlebiae simple. Fiddlehead ca. 0.5 $\mathrm{cm}$ in diameter, loosely scaly. Bud slender, ascending, opening rapidly, the scales lanceolate, basally rounded, apically long-acuminate, $(0.8) 1.5-2.5 \times(0.2) 0.4-0.7 \mathrm{~mm}$, golden-orange to brown, the margins short-dentate to entire, cell texture hyaline to semirigid-subclatrhade, the cells rectangular with thick cell walls. Pinnae $15-50 \mathrm{~cm}$, 3- to 4-(5-)forked, $1^{\text {st }}$ axis usually longer than the $2^{\text {nd }}, 2-7(15) \mathrm{cm}$ long and 0.5-1.5 $\mathrm{mm}$ thick, occasionally scatteredly pectinate, $2^{\text {nd }}$ axis $2-7(15) \mathrm{cm}$ long and $0.5-1 \mathrm{~mm}$ thick, sometimes pectinate, $3^{\text {rd }}$ and $4^{\text {th }}$ axis usually longer, (4)10-17 cm long and 0.5$1 \mathrm{~mm}$ thick, pinnatifid, occasionally with a $5^{\text {th }}$ axis, ca. $10 \mathrm{~cm}$ long and $0.5 \mathrm{~mm}$ thick, usually shorter than the previous, lanceolate, $0.8-1(1.2) \mathrm{cm}$ wide with segments, with 3.5-4.5 segments per cm; scales adaxially and abaxially absent. Segments (1.5)3$6(12) \times 1.5-2 \mathrm{~mm}$, oval to triangular, subchartaceous to herbaceous, the margins revolute, usually the first proximal internal segments reduced, glabrous; abaxially surface papillose, midvein and veinlets usually dark but not raised. Sori supramedial, reaching or starting at the apex, 4-9 pairs per segment, 3-5 sporangia per sorus.

Distribution and ecology. Mountains of Costa Rica, Panama, Colombia, and Ecuador, perhaps south to Bolivia. Common at (500)800-2500 m in montane forest on sandy or rocky surfaces, and along road banks. Grows solitarily or in small groups.

Sticherus hypoleucus is characterized by the glabrous abaxial axes and segments, spreading, narrowly lanceolate, long-acuminate, stoutly hyaline to clathrate, entire bud scales, narrowly lanceolate, rigid, entire rhizome scales, short, 
triangular aphlebiae, short, triangular, pinnatifid segments, and abaxially obscure veinlets. The clathrate texture of the bud scales leads to a characteristic pectinate appearance of the elongate scale apices. This species may be confused with $S$. gracilis which also has short, hastulate segments, but that species has ciliate, basally hardening bud scales, pinnatisect segments, and pectinate proximal axes (Tab. $\mathrm{x}$ ).

Some specimens from Guyana (Cuyuni-Mazaruni, Pakaraima Mts., NE Plateu of Mt., 5²3’N, 5958'W, 1500-1650 m, 1 Nov, 1992, Heckel 77, NY, US) and Colombia (Chocó, Bolivar-Quibdo hwy., 540’N, 76³0’W, Km 134.5, 1070 m, 13 Apr 1983, Juncosa 931, MO, US) are overall similar to S. hypoleucus, but have a scaly abaxial axis and whitish, forked midvein scales. These latter scales are otherwise only found in S. strictissimus and it is conceivable that these atypical specimens are hybrids between $S$. hypoleucus and S. strictissimus.

A collection from Bolivia (Santa Cruz, Florida, $5.5 \mathrm{~km}$ by road $\mathrm{N}$ of Campamento La Yunga of Paruqe Nacional Amboró, $0.5 \mathrm{~km}$ (by air) NE of Mairana, $18^{\circ} 04^{\prime} \mathrm{S}, 63^{\circ} 54^{\prime} \mathrm{W}, 2270 \mathrm{~m}, 6$ Jun 1998, Nee 49659, LPB, NY, USZ) is similar to $S$. hypoleucus, but has scales abaxially on the axes and thus approaches $S$. gracilis.

Tab. 3. Comparative characters of S. hypoleucus, S. gracilis, and S. gnidioides.

\begin{tabular}{llll}
\hline & S. hypoleucus & S. gracilis & S. gnidioides \\
\hline Axes & 2- to 3-forked & 1- to 3-forked & 4- to 5-forked \\
Segments present on & last axes & all axes & last axes \\
Abaxial axis scales & lacking & only proximal & lacking \\
Bud scale margins & entire & ciliate & entire \\
Pattern of bud scale hardening & marginal & basal & restricted to cell walls \\
Rhizom scales & linear-lanceolate & lanceolate & linear-lanceolate \\
Distribution & Central America to & southeastern Brazil & northern Andes \\
& central Andes & & \\
\hline
\end{tabular}

48. Sticherus gracilis (Mart.) Copel. Gen. Fil. 27. 1947

Mertensia gracilis Mart., Icon. P1. Crypt. Brasil 107. Tab. 59. 1834. Gleichenia gracilis (Mart.) Moore, Ind 378. 1862. Type. Brasil, Santa Catarina, Martius s.n. (holotype, M?, not found). 
Plants small. Rhizome 3-4 mm thick, rugose, dark-brown, usually densely scaly, the scales narrowly lanceolate, $2-2.5 \times 0.2-0.3 \mathrm{~mm}$, orange, the margins with few, thin cilia, cell texture semirigid with square to rectangular, along the margins with illdifferentiated cells. Petiole 1-2.5 mm thick and 20-50 cm long, light brown to beige. Rachis ca. 7-10 cm long between pinnae, deciduously scaly; aphlebiae absent. Fiddlehead ca. 5-7 mm in diameter, densely scaly, the scales golden-orange. Bud medium-sized, ascending and opening rapidly, the scales narrowly lanceolate, basally truncate, apically long-acuminate, $1.5-3 \times 0.3-0.5 \mathrm{~mm}$, orange to bicolorous with dark brown bases or completely dark (including the margins), the margins with straight cilia or setae $1 / 10 \mathrm{x}$ the scale length, cell texture stoutly-hyaline to rigid, the cells rectangular, ill-defined. Pinnae $15-40 \mathrm{~cm}$ long, axes 3 - to 4 -forked, $1^{\text {st }}$ axis longer that the $2^{\text {nd }}, 3-4 \mathrm{~cm}$ long and $0.5-1 \mathrm{~mm}$ thick, usually only with internal proximal segments, $2^{\text {nd }}$ to $4 \mathrm{~cm}$ long and 0.5-1.2 mm thick, $3^{\text {rd }}$ axes (5) $10-18 \mathrm{~cm}$ long and ca. $1 \mathrm{~mm}$ thick, usually distal, $4^{\text {th }}$ axis $5-15 \mathrm{~cm}$ long and ca. $0.5 \mathrm{~mm}$ thick, the last two axes usually of similar length, deeply pinatifid to pinnatisect, from the $2^{\text {nd }}$ axis onwards narrowly lanceolate, (7)14-25 mm wide with segments; scales adaxially lacking; scales abaxially and laterally lacking or present only near the bud, similar to those of the bud. Segments $0.9-1.5 \times 1.5-3 \mathrm{~mm}$, long-triangular, the margins slightly revolute, subcoriaceous; adaxially and abaxially glabrous; veinlets abaxially weakly marked, brown and diverging, glabrous. Sori medial, placed on the segment center and apex, nested within fimbriate to hair-like, whitish, hyaline scales, (3)5-9 pairs per segment, 3-5 sporangia per sorus.

Distribution and ecology. Endemic to central and southeastern Brazil (Distrito Federal, Minas Gerais, Rio de Janeiro, Sao Paulo, Paraná, Santa Catarina). In semihumid forest and along forest margins in the cerrado region, at ca. 1100-1300 m.

Sticherus gracilis resembles $S$. hypoleucus, but has ciliate, basally hardening bud scales, pinnatisect segments, pectinate proximal axes, scaly midveins, and thicker, more densely scaly rhizomes (Tab. x). Most specimens of S. gracilis have previously identified as $S$. lanosus (using the synonym name $S$. penniger), but $S$. lanosus has 4- to 6-forked axes, shorter proximal axes, and densely scaly pinnae with narrowly lanceolate to fimbriate scales. 
49. Sticherus gnidioides (Mett.) Nakai. Bull. Natl. Sci. Mus. 29: 18. 1950.

Gleichenia gnidioides Mett., Ann. Sci. Nat. Bot. Sér 5, 2: 226. (repr. 348). 1864.

Type. Colombia, Chocó, Acostadero, Triana 659 (holotype, BM).

Plants small, slender. Rhizome 2-3 mm thick, light brown, sparsely scaly, the scales lanceolate, long-acuminate, $1-3 \mathrm{x}$ ca. $0.3 \mathrm{~mm}$, golden-yellow, the margins denticulate, cell texture grated, the cells, large, narrow, ill-differentiated. Petiole over $20 \mathrm{~cm}$ long and 3.5-5 mm thick, brown, subpaleaceus. Rachis ca. $10 \mathrm{~cm}$ long between pinnae, deciduously scaly; aphlebiae simple. Fiddlehead ca. $0.5 \mathrm{~cm}$ in diameter, with few scales. Bud large, ascending, opening rapidly, the scales lanceolate, basally rounded, apically long-acuminate with a complex hair 1 to 2 cell rows wide, (0.5)2-3 x 0.1-0.3 mm, dusty orange, the margins dentate, cell texture semiclathrate, the cells square. Pinnae ca.15-25 cm long, axes usually 5-forked, $1^{\text {st }}$ axis longer than the $2^{\text {nd }}$ to $4^{\text {th }}, 3.5-6.5 \mathrm{~cm}$ long and $1.5-2 \mathrm{~mm}$ thick, with only a simple, inconspicuous to reduced internal segment; $2^{\text {nd }}$ axis $2-4 \mathrm{~cm}$ long and $0.8-1$ $\mathrm{mm}$ thick, not pectinate; $3^{\text {rd }}$ and $4^{\text {th }}$ axis $2-3 \mathrm{~cm}$ long and ca. $1 \mathrm{~mm}$ thick, pinnatisect, lacking proximal segments on the first $0.5-1 \mathrm{~cm}, 5^{\text {th }}$ axis pinnatifid, $7-18 \mathrm{~cm}$ long and ca. 0.5 mm thick, 3-3.5 mm wide with segments, with 4-5 segments per cm; adaxially glabrous; abaxially and laterally sparcely scaly, the scales lanceolate, longacuminate with an apex ca. $4 \mathrm{x}$ the length of the scale body, $0.8-1.2 \mathrm{x}$ ca.0.2 mm, 4 cell rows wide, orange-brown, the margins entire, cell texture semiclathrate with square cells. Segments triangular, obliquely hastulate, wider on the acroscopic side, (0.5)1.5-2(3) x 1-1.5(3) mm, thick, opaque, margins revolute; adaxially glabrous; abaxially with papillae covering the midvein and veinlets; veinlets basally 1 -forked, apically simple, usually glabrous but sometimes with hyaline, hair-like scales. Sori grouped at the segment base, 3-4 pairs per segment, 4-5 sporangia per sorus.

Distribution and ecology. Western Andean slope and adjacent lowlands in Colombia and Ecuador. Rheophytic along rivers on rocks and sand. Shows rheophytic adaptations such as the narrow angles of the axes, the thick petiole, and the robust rhizome. Rare and local at 0-600 $\mathrm{m}$, but possibly also higher. 
Due to its rheophtic ecology, Sticherus gnidioides has a unique appearance within the genus. The segments are very shortly triangular and the last axes appear as serrate. It is further recognized by its relative thick petiole and rachis with slender axes, 4- to 5-forked axes, long $1^{\text {st }}$ axes, spreading, linear-lanceolate, subclathrate bud scales, and glabrescent segments. It is probably most closely related to $S$. pteridellus but that species is larger overall and has ovate, hyaline bud scales. Both species may possibly hybridise in Panama, producing plants resembling $S$. gnidioides but with ovate bud scales (see under hybrids).

50. Sticherus retroflexus (J. Bommer ex H. Christ) Copel., Gen. Fil. (Ann. Cryptog. Phytopathol. 5: 28) 1947.

Gleichenia intermedia Baker var. flexuosa Baker, Journal of Botany British and Foreing 25: 24. 1887. Gleichenia retroflexa J. Bommer ex H. Christ, Bull. Herb. Boissier. 4: 657. 1896. Type. Costa Rica, La Palma, Pittier 1471 (holotype, BR).

Plants small to medium-sized, slender. Rhizome 1-1.5 mm thick, brittle, brown, deciduously scaly, the scales ovate to rounded, basally cordate, ca. 0.5 x 0.3-0.5 mm, the margins entire, cell texture hyaline-semiclathrate. Petiole ca. $30 \mathrm{~cm}$ long and 1 $\mathrm{mm}$ in diameter, brittle. Rachis to $15 \mathrm{~cm}$ long between pinnae, castaneous, glabrous; aphlebiae trifoliate, pinnatifid. Fiddlehead ca. $0.5 \mathrm{~cm}$ in diameter, blackish, glabrous or with a few scales. Bud small, completely covered by the aphlebiae, loosely scaly, the scales ovate to rounded, basally cordate, apically cuspidate, ca. $0.7 \times 0.5 \mathrm{~mm}$, orange to bicolorous with dusty orange bases, the margins entire, cell texture hyaline with short, square to irregular cells. Pinnae 15-30 cm long, to 2-forked (rarely 3forked), $1^{\text {st }}$ axis $1-3 \mathrm{~cm}$ long and $0.5-1 \mathrm{~mm}$ thick, not pectinate, $2^{\text {nd }}$ axis and usually distal $10-20 \mathrm{~cm}$ long and ca. $0.5 \mathrm{~mm}$ thick, flexuous, pectinate, with a single segment placed at each angle, distal axes usually with conform apices; adaxially and abaxially glabrous. Segments linear with hastulate bases, acroscopic lobule larger, segments separated by $0.5 \mathrm{~cm}$, the margins crenate; adaxially glabrous; abaxially papillose, whitish; veinlets greenish to slightly brown, not raised. Sori medial, usually restricted to the segment center, if reaching the segment apex, then the sori remain immature or have abortive sporangia, 15-20 pairs per segment, 3-6 sporangia per sorus. 
Distribution and ecology. Nicaragua, Costa Rica, and Panama. On steep slopes along forest margins, landslides, and road banks, forming thickets in open disturbed sites, often mixed with other species of Gleicheniaceae, at 1100-2800 m.

This species belongs to a group of four closely related species, together with S. hastulatus, $S$. orthocladus, and $S$. intermedius. They all have scales entirely restricted to the buds and rhizome, hastulate, in some species short-petiolate segments, accessory segments on the pinna bases, 2- to 3-forked veinlets on the auriculate segment bases, obscure veinlets, abaxial papillae in most species, slightly to strongly undulate segment margins, and ovate, entire, hyaline to stoutly hyaline scales. The characters separating the species are listed in Tab. x. All four species cooccur in Costa Rica and often form mixed populations. They grade into each other, with $S$. retroflexus and $S$. intermedius as the most distinct forms and $S$. hastulatus and $S$. orthocladus as intermediate forms. It is conceivable that the latter are hybrids between $S$. retroflexus and $S$. intermedius, but more detailed studies are needed to evaluate this matter.

Sticherus retroflexus is recognized by its slender, strongly flexuous, widely spreading axes with a single segment placed on each axis angle, and slender, shiny, aggregated rhizomes. In dense natural populations, the flexuous, spreading axes of many individuals form dense, intertwined masses. It is most similar to $S$. hastulatus which mainly differs in its shorter, short-petiolate segments. 
Tab. 4. Comparative characters of $S$. retroflexus, $S$. hastulatus, $S$. orthocladus, and $S$. intermedius.

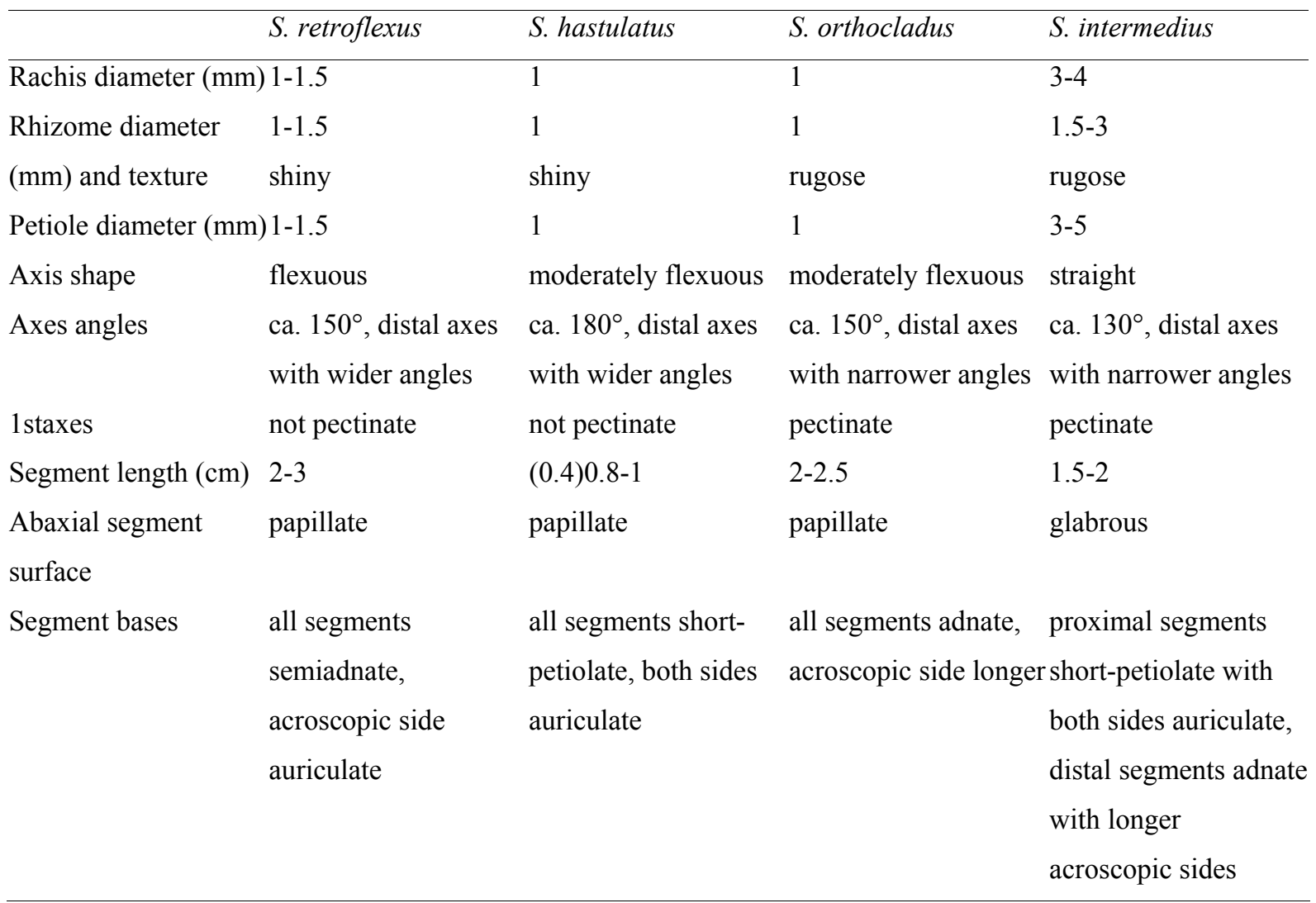

51. Sticherus orthocladus (H. Chist) Chrysler, Amer. J. Bot. 31: 483. 1944.

Gleichenia orthoclada H. Chist, Bull. Herb. Boissier, ser. 2, 5: 16. 1905.

Dicranopteris orthoclada (H. Chist) Underw., Bull. Torrey Bot. Club 34: 259. 1907.

Type. Costa Rica, 1903, Wercklé 212. (holotype, P; photo, BM).

Gleichenia intermedia var. dissitifolia Baker, J. Bot. 25: 24. 1887. Gleichenia dissitifolia (Baker) L. D. Gomez, Brenesia 12-13: 69. 1977. Type. Costa Rica, Cartago, Valle de Estrella, 1600-1800 m, Cooper s.n. (holotype, K; isotype, GH, US).

Plants small, slender. Rhizome 1-1.5 mm thick, aggregate, rugose, blackish, the scales deciduous, ovate, basally cordate, $0.5-1 \times 0.3-0.4 \mathrm{~mm}$, dusty orange, the margins entire, cell texture stoutly hyaline with square to rounded cells. Petiole ca. $30 \mathrm{~cm}$ long and 1-1.5 mm thick, castaneous. Rachis ca. $10 \mathrm{~cm}$ long between pinnae, 
glabrous; aphlebiae large, trifoliate, basiscopic. Bud very small, closed, loosely scaly, the scales ovate to rounded, basally cordate, $0.1-0.2 \mathrm{~mm}$, orange, the margins entire, cell texture hyaline with rounded cells. Pinnae $15-25 \mathrm{~cm}$ long, axes slightly flexuous, 1 - to 2-forked, forming angles less than $150^{\circ}, 1^{\text {st }}$ axis $2-3 \mathrm{~cm}$ long and $1 \mathrm{~mm}$ thick, with internal segments, $2^{\text {nd }}$ axis $10-15 \mathrm{~cm}$ long and ca. $0.5 \mathrm{~mm}$ thick, pinnatisect, 2-5 cm wide with segments, with ca. 2 segments per cm; adaxially and abaxially glabrous. Segments adnate, hastulate, acroscopic side longer, 1-2.5 cm long and 1.5-2 mm wide, the margins chartaceous to slightly serrate; adaxial surface glabrous; abaxially surface scatteredly papillate; veinlets dark, obscure, basally on the acroscopic side sometimes 2-forked. Sori medial, ca. 10 pairs per segment, 3-4 sporangia per sorus.

Distribution and ecology. Rare in open habitats in humid montane forest at 1600$1800 \mathrm{~m}$ in Costa Rica.

Sticherus orthocladus is morphologically intermediate between S. retroflexus and S. intermedius, and may be of hybrid origin between those two species. It differs from $S$. retroflexus in its slightly flexuous axes with narrow angles, pectinate $1^{\text {st }}$ axes, rugose rhizomes, and adanate segments (Tab. x). From $S$. intermedius, it can be distinguished by its much narrower rachises and rhizomes, narrower segments, slightly flexuous axes, and papillose abaxial segment surfaces.

52. Sticherus hastulatus (Rosenst.) Nakai, Bull. Natl. Sci. Mus. 29: 18. 1950.

Gleichenia hastulata Rosenst. Repert. Spec. Nov. Regni. Veg. 10: 274. 1912. Type. Costa Rica, La Palma, in udis, apricis, graminosis, 1400 m, 1910, Brade 502, (holotype, S; photo, BM).

Plants small, slender. Rhizome not differenciated from the petiole, ca. $1 \mathrm{~mm}$, brittle, brown, sparsely scaly, the scales ovate, basally sagittate, $0.8-1 \times 0.07-0.6 \mathrm{~mm}$, the margins entire, cell texture hyaline with well differentiated wall cells. Petiole to ca. $20 \mathrm{~cm}$ long, castaneous. Rachis ca. $10 \mathrm{~cm}$ long between pinnae, glabrous; aphlebiae basiscopic. Bud small, closed, the scales scattered, ovate to rounded, (0.4)0.6-1 x 0.07-0.6 mm, concolorous, orange, the margins entire, cell texture hyaline, the cells 
square to rounded. Pinnae $7-25 \mathrm{~cm}$ long, 2 - to 3 - forked, spreading at $>90^{\circ}$ angle, $1^{\text {st }}$ axis the shortest, $0.6-2 \mathrm{~cm}$ long, $0.5 \mathrm{~mm}$ thick, with aphlebiae to $10 \mathrm{~mm}$ long, not pectinate; $2^{\text {nd }}$ axes forming angles to $170^{\circ}, 6-20 \mathrm{~cm}$ long and $0.2-0.5 \mathrm{~mm}$ thick, slightly flexuosus, pinnatisect, $1.5-4.2 \mathrm{~cm}$ wide with segments, with ca. 3 segments per cm; adaxially and abaxially glabrous. Segments basally constricted, hastulate, bases unequal, the acroscopic lobule slightly longer and usually overlapping the axis, (0.4)0.8-2.3 cm long, the margins chartaceous to slightly serrate, adaxially and abaxially glabrous; veinlets adaxially dark but not raised. Sori inframedial, ca. 4 pairs per segment, 3-4 sporangia per sorus.

Distribution and ecology. Endemic to the mountains of Costa Rica and Panama, in montane forest at 1100-1500 m. Local and uncommon on steep banks below waterfalls, in windswept places with shrubby vegetation, or on rocky surfaces.

Sticherus hastulatus is a rare species that is closely related to $S$. retroflexus and S. orthocladus (Tab. 4). It differs from the first of these in its shorter size, more widely spreading, less flexuous, somewhat narrower axes, and specially in its shorter, short-petiolate, auriculate segments. Relative to $S$. orthocladus, S. hastulatus lacks segments on the 1st axes, has shiny rhizomes, and has shorter segments.

53. Sticherus intermedius (Baker) Chrysler, Amer. J. Bot. 31: 483. 1944

Gleichenia intermedia Baker, Journ. Bot. Brit. \& For. 25: 24. 1887. Gleichenia intemedia Baker var. intermedia, Hooker's J. Bot. 24. 1887. Dicranopteris intermedia (Baker) Underw., Bull. Torrey Club 34: 258. 1907. Type. Costa Rica, Cooper 17 (holotype, K).

Gleichenia axialis H. Christ, Bull. Herb. Boiss. II. 5: 14. 1905. Type. Costa Rica, Werckle s.n. (Morton Neg. No. 4494) (holotype, P; photo BM).

Gleichenia trachyrhizoma Christ, Bull. Boiss., II, 6: 280. 1906. Type. Costa Rica, Werckle s.n. (Morton Neg. No. 4541) (holotype, P; Photo, BM). 
Plants medium-sized, robust. Rhizome 3-4 mm thick, dark brown, sparsely scaly, the scales ovate, cuspidate, 1.3-2.8 x 1.3-1.7 mm, dark brown, the margins entire, cell texture clathrate with square cells. Petiole over $30 \mathrm{~cm}$ long and $3-5 \mathrm{~mm}$ thick, orange to castaneous. Rachis ca. $25 \mathrm{~cm}$ long between pinnae; aphlebiae large, trifoliate. Fiddlehead ca. $1 \mathrm{~cm}$ in diameter, sparsely scaly. Bud small, closed, the scales ovate, basally cordate, 1.3-1.9 x (0.1)0.7-1.3 mm, concolorous, orange, cell texture hyaline with short rectangular to rounded cells. Pinnae to $30 \mathrm{~cm}$ long, 1- to 2-(3-)forked, $1^{\text {st }}$ axis the shortest, $2-4 \mathrm{~cm}$ long and ca. $1.5 \mathrm{~mm}$ thick, with trifoliate aphlebiae, pinnatisect; $2^{\text {nd }}$ axis $15-20 \mathrm{~cm}$ long and ca. $1 \mathrm{~mm}$ thick, pinnatisect, $2.5-4 \mathrm{~cm}$ wide with segments, with ca. 2 segments per $\mathrm{cm}$. Segments triangular, subchartaceous, the margins revolute; abaxially with whitish to orange, slightly raised veinlets, first proximal veinlets to 4-forked. Sori medial, 5-12 pairs per segment, 3-5 sporangia per sorus.

Distribution and ecology. Endemic to the mountains of Costa Rica and adjacent Panama. Locally distributed in humid montane forest at 1500-2200 m, growing in open thickets on hillsides, on road banks, and on eroded slopes. Often co-occurs with S. retroflexus.

Sticherus intermedius is a very distinctive species related to $S$. retroflexus and its allies, but is by far the largest species in this group. It is characterized by its straight, fully pectinate axes, smooth abaxial segment surfaces, and short-petiolate, auriculate segments on the proximal axes while the distal axes have adnate segments. In the field, it has a very distinctive, erect habit quite unlike any other species of the genus. 


\section{HYBRIDS}

Only formally named hybrid taxa are fully described here, for the other hybrids only a brief discussion is given. See also the general discussion on hybridisation in the introduction.

54. Sticherus x pseudobifidus (Jermy \& T. Walker) J. Gonzales, comb. nov.

Gleichenia x pseudobifidus Jermy \& T. Walker, Bull. Brit. Mus. (Nat. Hist.), Bot. ser. 13: 2. 1985. Type. Trinidad, Arima-Blanchisseuse Road, ca. $10^{\circ} 58^{\prime}$ N, 6110' W, 450 m, Walker 6414 (holotype, BM).

Plants large, robust. Rhizome 1.5-3 mm thick, dark brown, sparsely scaly, the scales lanceolate, basally truncate, apically acuminate, $0.5-1 \times 0.2-0.3 \mathrm{~mm}$, dark brown to reddish, the margins setose, cell texture rigid to semiclathrate, the cells rectangularwith thick walls. Petiole ca. $80 \mathrm{~cm}$ long and $2.5-4 \mathrm{~mm}$ thick, dark brown, brittle. Rachis $>30 \mathrm{~cm}$ between pinnae, subpaleaceus; aphlebiae trifoliate with narrow, long, usually overlapping segments. Fiddlehead ca. 4-6 mm in diameter, densely scaly, the scales matted, dusty brown. Bud small, appressed, the scales narrowly lanceolate, usually apically glandular, (0.8)1-2.2 x $0.3-0.4 \mathrm{~mm}$, orange to bicolorous with brown bases, the margins with straight, thin cilia $1 / 5-1 / 3 \times$ the scale length, cell texture grated hyaline to mixed, the cells square. Pinnae 30-65 cm long, 2- to 3-forked, $1^{\text {st }}$ axis 4-7 $\mathrm{cm}$ long and 2-3 $\mathrm{mm}$ thick, opposite axes of unequal length, not pectinate or remotely pectinate, $2^{\text {nd }} 8-30 \mathrm{~cm}$ long and $1-2 \mathrm{~mm}$ thick, opposite axes of unequal length, usually remotely pectinate, with 1.4 to 2.3 segments per $\mathrm{cm}, 3^{\text {rd }}$ and last axis $13-40 \mathrm{~cm}$ long and $0.8-1 \mathrm{~mm}$ thick, pinnatisect, (4)7-10 cm wide with segments, with 1.6-2 segments per cm; adaxial scales deciduous, mixed, one type fimbriate, $0.5-0.8 \times 0.05 \mathrm{~mm}$, the second type reduced, lanceolate, $0.2-1.4 \mathrm{x}$ $0.1 \mathrm{~mm}$, both scale types whitish to light orange (specially on young pinnae), hyaline; abaxial scales ca. $0.4 \times 0.2 \mathrm{~mm}$, orange, the margins with cilia ca. $3 \times$ the scale length, cell texture grated-hyaline with square cells; lateral scales lanceolate to triangular, apically fringed and sometimes glandular, 1-1.4 x 0.2-0.3 $\mathrm{mm}$, orange, the margins with cilia 1/3-1/2 $x$ the scale length, cell texture grated-hyaline with square cells. Segments linear, obtuse from a broadened base, herbaceous, 3-5 cm long and 
1.5-3 mm wide, the margins narrowly revolute; scales abaxially sparse, covering $15 \%$ of the leaf surface; midvein scales mixed, one type hair-like, ca. $1 \times 0.05 \mathrm{~mm}$, the second type star-shaped, usually with a long apical cilium, 0.2-0.5 x 0.1-0.2 mm, the margins with cilia 1/3-1 x the scale length, cell texture grated-hyaline; abaxial surface sparsely scaly, the scales arachnoid, ca. 0.05-0.3 $\mathrm{mm}$ in diameter. Sori inframedial, slightly nested within arachnoid scales, ca. 10-15 pairs per segment, 3-4 sporangia per sorus, spores usually abortive, dusty orange.

Distribution and ecology. Best known in Trinidad, where fairly common along roadsidses in humid forest on the northern mountain range at $200-450 \mathrm{~m}$, but also known from scattered specimens from Panama, Cuba, Dominica, Grenada, and northern and southeastern Venezuela. Likely to be more common and widespread than currently known.

This triploid hybrid between $S$. interjectus and $S$. ferrugineus was described by Jermy \& Walker (1986) on the basis of cytotaxonomic studies of the ferns of Trinidad. It is similar in size to $S$. interjectus but has a much denser indument abaxially on the segments, thus approaching $S$. ferrugineus. On the other hand, $S . \mathrm{x}$ pseudobifidus differs from $S$. ferrugineus species in having irregularly hardened parts on the bud and axis scales, while $S$. ferrugineus has completely hyaline or only basally hardened scales. Sticherus x pseudobifidus has conspicuously irregular segment lengths, a character shared by $S$. x subremotus. Also, both hybrid taxa have strikingly unequally developed 2 nd axes, i.e., opposite pairs of axes have different lengths.

55. Sticherus x subremotus (Jermy \& T. Walker) J. Gonzales, comb. nov.

Gleichenia x subremota Jermy \& T. Walker, Bull. Brit. Mus. (Nat. Hist.), Bot. 13: 2. 1985. Type. Trinidad, Blanchisseus Ward, 450 m, Walker 6416 (holotype, BM).

Plants large, robust, similar to $S$. remotus in size and habit. Rhizome unknown. Petiole $4.5 \mathrm{~mm}$ thick, brown. Rachis subpaleaceous; aphlebiae trimerous to simple. Fiddlehead 1.5-3 mm in diameter, densely scaly, matted, the scales brown. Bud small, slightly appressed, the scales lanceolate, long-acuminate with an apex ca. 1 
mm long, 1-2 x 0.4-0.6 mm, basally ca. 12 cell rows wide, bicolorous with dark orange centers and whitish margins, the margins with twisted, thick, contorted cilia $1 / 5 \mathrm{x}$ the scale length, cell texture stoutly hyaline to mixed with hardened scales restricted to the center and apex, the cells square to rounded. Pinnae $30-50 \mathrm{~cm}$ long, 3 -forked, $1^{\text {st }}$ axis ca. $9 \mathrm{~cm}$ long and $0.3 \mathrm{~mm}$ thick, only with internal proximal segments, $2^{\text {nd }}$ axis longer, opposite axes of unequal length, ca.14-27 cm long and 2.5 $\mathrm{mm}$ thick, pectinate, with segments unequal in size and irregularly arranged, interconnected by chartaceous, brown wings, $3^{\text {rd }}$ axis ca. $45 \mathrm{~cm}$ long and $1.7 \mathrm{~mm}$ thick, linear-lanceolate, pectinate, $5.8-7 \mathrm{~cm}$ wide with segments, with 1-2 segments per $\mathrm{cm}$, proximal internal segments gradually reduced, overlapping; adaxial scales covering ca. $15 \%$ of the axes, linear, whitish-hyaline, with erose margins; abaxially similar to those of the bud, but (1)1.2 $\mathrm{mm} \times 0.4-0.5 \mathrm{~mm}$, whitish-hyaline to light orange, the margins ciliate with a fringed or tufted apex, the cells rectangular to irregular. Segments linear, chartaceous, 0.8-3.4 x $2 \mathrm{~mm}$, the margins narrowly revolute; adaxially glabrous; abaxial scales covering ca. $10-15 \%$ of the surface, reduced, arachnoid, whitish; midvein scales mixed, one type hair-like, $1.6 \times 0.1 \mathrm{~mm}$, orange to hyaline, the cells long and narrow, the second type triangular to irregularly shaped, $0.4 \times 0.2 \mathrm{~mm}$, whitish-hyaline, the cells irregular, both scale types with marginal cilia 1/2-1 x the scale length. Sori inframedial, nested within a few reduced or hair-like scales, ca. 23 pairs per segment, 3 sporangia per sorus.

Distribution and ecology. Trinidad and Jamaica, likely to be more widespread. On open bank at forest edge or along roadsides, forming mixed colonies with $S$. interjectus and S. remotus at 60-600 $\mathrm{m}$.

This hybrid between $S$. interjectus and $S$. remotus was cytologically studied and described by Jermy and Walker (1985). It differs from $S$. interjectus by the more rounded and broader bases of the bud scales, from $S$. remotus by the approximate segments, scatteredly indumented abaxial segment surfaces, and from both these species by its less regularly shaped and hardened cells. While many species in this species complex have unequally developed $2^{\text {nd }}$ axes, this pattern in particularly conspicuous in $S$. x subremotus. 
56. Sticherus $x$ leonis (Maxon) J. Gonzales comb. nov.

Dicranopteris leonis Maxon, Jour. Wash. Acad. Sci. 12: 439. 1922. Gleichenia x leonis (Maxon) C. Chr., Ind. Fil. Suppl. 3: 106. 1934. Type. Cuba, Oriente, high Sierra Maestra, Pico Turquino, León 11092 (holotype, US, isotype NY).

Plants medium-sized, robust. Rhizome 3-5 mm thick, densely scaly, the scales falcate to long lanceolate, $4-5 \times 1 \mathrm{~mm}$, dark brown, the margins setose, cell texture rigid with linear cells. Petiole $>30 \mathrm{~cm}$ long and ca. $4 \mathrm{~mm}$ thick, opaque, castaneous. Rachis ca. 15-25 cm long between pinnae, subpaleaceus, the scales dark orange; aphlebiae narrowly trimerous. Fiddlehead ca. $1 \mathrm{~cm}$ in diameter, densely scaly, the scales matted, star-shaped, lax-hyaline, golden-orange. Bud large, appressed and opening rapidly, the scales lanceolate, 4-6 x $1 \mathrm{~mm}$, dusty orange with dark brown center and bases, the margins short-ciliate, cell texture stoutly hyaline to mixed with hardened bases, the cells rectangular to linear. Pinnae 30-40 cm long, 3- to 4-forked, $1^{\text {st }}$ axis $3.5-7 \mathrm{~cm}$ long and $1.5-3.5 \mathrm{~mm}$ thick, sometimes longer than the $2^{\text {nd }}$, not pectinate, $2^{\text {nd }}$ axis $2.5-6.5 \mathrm{~cm}$ long and $1-2.5 \mathrm{~mm}$ thick, occasionally with scattered internal segments, both proximal axes usually densely scaly, $3^{\text {rd }}$ axis $4-20 \mathrm{~cm}$ long and 1-2 mm thick, pectinate but lacking proximal internal segments on the first 0.5 $1.5 \mathrm{~cm}, 3.5-4.5 \mathrm{~cm}$ wide with segments, $4^{\text {th }}$ and usually distal axis (7)20-30 $\mathrm{cm}$ long and (0.5)1.5-2 mm thick, lanceolate, basally unequally truncate, (2)3.5-5 cm wide with segments, with ca. 2.5 segments per $\mathrm{cm}$, proximal internal segments overlapping; adaxial scales linear-laneolate to lanceolate, basally truncate, 1.7-2.7(4) $\mathrm{x}$ 0.1-0.2 mm, orange to whitish, cell texture stoutly hyaline, the margins with cilia ca. $1 / 8 \mathrm{x}$ the scale length; abaxially moderately to densely scaly, the scales lanceolate, basally truncate, apically glandular or extended to a long, twisted hair, $(0.5) 1-2.6(3) \times(0.1) 0.3-0.7 \mathrm{~mm}$, ca. 5 cell rows wide at the base, orange, the margins with numerous and straight cilia 1/4-1/2 x the scale length, cell texture stoutly hyaline with short, rectangular cells. Segments 1-2.5 cm long and (1.5)2-3.5 mm wide, cylindrical, herbaceous, pinnatisect to slightly remote, the margins ciliate, slightly revolute; adaxially glabrous; abaxially scaly on midvein and veinlets; midvein scales fibrillar to star-shaped, (0.06)0.2-1(2) x 0.01-0.06 mm, pale orange to whitish, the margins with few and thick cilia 1/3-3 x the scale length, hyaline; veinlets slightly raised, sparsely scaly, the scales star-shaped or hair-like, whitish, 
hyaline. Sori medial to inframedial, restricted to the centers of the segments, not nested in scales, 17-21 pairs per segment, 3-6 sporangia per sorus.

Distribution and ecology. Only known from humid forest edges at $1200-2000 \mathrm{~m}$ in Provincia del Oriente, Cuba, but to be expected where the parent taxa co-occur, e.g., in Mexico, Guatemala, and Jamaica (Duek, 1974).

Specimens studied: Only the type was studied here. Additional specimens at IBH are listed in Duek (1974).

This hybrid was originally described by Maxon (1922) as a distinct species, but Duek (1974) recognized that all specimens appear to be sterile, with few sporangia, and aborted spores. Duek postulated that the parent species are $S$. ferrugineus (called by Duek S. bifidus) and S. furcatus (as S. palmatus). I believe that the parent taxa may actually be $S$. hispaniolensis and $S$. furcatus because the bud scales are large, bicolorous, basally rigid and marginally hyaline, and thus very similar to those of S. hispaniolensis, while the glabrous abaxial segments, and triangular-lanceolate abaxial axis scales are reminiscent of $S$. furcatus.

57. Sticherus gnidioides (Mett.) Nakai x Sticherus pteridellus (H. Christ) Copel.

This specimen resembles $S$. gnidioides but has ovate bud scales as in $S$. pteridellus.

Specimen studied: Panama, Copé, East side to Atlantic, 200-400 m, Hamilton \& Davidse 2608 (BM, MO, U).

58. Sticherus hypoleucus (Sodiro) Copel. $\mathbf{x}$ Sticherus remotus (Kaulf.) Chrysler

This hybrid was recognized by Østergaard \& Øllgaard (2001). It is intermediate between the putative parent taxa and co-occurred with them.

Specimen studied: Ecuador, Morona-Santiago, road Susana de Chiviasa-Panecillo, km 3-4 (NE of Limón), 1300 m, Øllgaard \& Navarrete 2699 (AAU). 
59. Sticherus ferrugineus (Desv.) J. Gonzales x Sticherus furcatus (L.) Ching

This specimen is very similar to $S$. x leonis but has shorter, narrower bud scales, and some indument on the abaxial segment surface. It therefore possibly involves $S$. ferrugineus (rather than $S$. hispaniolensis) as one of the parent taxa.

Specimen studied: Colombia, Karsten, s.n. (B).

60. Sticherus fulvus (Desv.) Ching $\mathbf{x}$ S. retroflexus (J. Bommer ex H. Christ) Copel.

This specimen has a slender rhizom, brittle, glabrous, slightly flexuos axes, linear to hastulate, remotely pectinate segments, and wing-like proximal internal segments.

Specimen studied: Costa Rica, Cartago, Rio Grande de Orosi, 1500-1700 m, 10 Feb 1985, Grayum 5103 (MO).

61. Sticherus melanoblastus (Alston) Østergaard \& B. Øllgaard x Sticherus tomentosus (Cav. ex Sw.) A.R. Smith

This possible hybrid specimen was recognized by Østergaard \& Øllgaard (2001) who hesitated to designate it as such because the spores appeared not be malformed. However, normal spores have also been observed in other hybrid specimens of Sticherus, and the other morphological characters strongly suggest hybridization. The specimen has intermediate morphology between the putative parent taxa, hybrid vigor (segments to $8.5 \mathrm{~cm}$ long), and grew as a single individual among large populations of the putative parents (Østergaard \& Øllgaard, 2001).

Specimen studied: Ecuador, Loja, trail ca. $5 \mathrm{~km}$ ENE of San Pedro de Vilcabamba, from “El Bosque" to Quebrada Romerillos, 2100-2200 m, Øllgaard \& Navarrete 105881 (AAU). 


\section{Sticherus simplex (Desv.) Ching x Sticherus revolutus (Kunth) Ching}

This hybrid was first recognized by Østergaard \& Øllgaard (2001). It is morphologically intermediate between $S$. simplex and $S$. revolutus, and has partly aborted spores. With S. simplex it shares the segment length, and the shape, cell texture of the abaxial axis and bud scales, while the similarities with $S$. revolutus are found in the 1- to 2-forked pinnae, and the hair-like scales on the adaxial axes. The midvein scales are a mixture of star-shaped scales (as in S. simplex), arachnoid scales, and linear scales (as in S. revolutus).

Specimens studied: Venezuela, Mérida, Páramo d ela Negra, above Cañada, 2800, 14 Feb 1939, Alston 7040 (BM); Ecuador, Azuay, N of Paute, 13 Apr 1945, Camp 2589 (AAU, NY); Cuenca, Baños, Yanasacha, 2925 m, 29 Dec 1976, Boeke 676 (NY); Road Cuenca-Cajas, ca. km 8, road to Bosque Protector Río Mazán, 30503150 m, Ulloa 473 (AAU); Llantera-Chiquintad-Saucay-Guandum, 3050 m, Jaramillo 1062 (AAU); Peru, San Miguel, Cajamarca, El Tingo, 2750 m, 20 Jun 1980, Sagástegui et al. 9510 (NY). 


\section{DOUBTFUL NAMES}

Gleichenia salesiana Bosco, Nuovo Giorn. Ital. 45: 151, t. 13, f. 1. 1938. Type not specified by author, name typified by illustration.

I have not seen original material of this species and am therefore uncertain of the application of this name. Østergaard \& Øllgaard (2001) considered it to be similar to S. strictissimus.

Mertensia immersa Kaulf., Enum. Filic. 38. 1824. Gleichnia immersa (Kaulf.) Spreng., Syst. Veg. 4: 27. 1827. Type. Brazil, Est. Santa Catarina, Chamisso s.n. (holotype, not located; isotype, $\mathrm{M}$ ).

The isotype seen merely consists of a pinna fragment. The segment shape and scale patterns suggest that this taxon belongs with $S$. decurrens, but the available material is insufficient evidence.

Sticherus cundinamarcensis (Hieron) Nakai, Bull. Natl. Sci. Mus. 20: 15. 1950. Gleichenia cundinamarcensis Hieron., Hedwigia 48: 286-287. 1909. Type.

Colombia, Cundinamarca, Batatas valley, Stübel 588 (holotype, not located).

No type material of this taxon was located. The original description and illustration show slightly arched axes and possibly aphlebiae. The scale description suggests that $S$. cundinamarcensis may be related to $S$. nervatus (which lacks aphlebiae). 


\section{ACKNOWLEDGEMENTS}

I want to thank my tutors Prof. Dr. S. Rob Gradstein and Dr. Michael Kessler, not only for the orientation they provided, but also for the notable dedication and pacience in directing my work. I especially want to emphasize the dedication of $\mathrm{M}$. Kessler in providing direct criticisms, in translating my work into English, and by making my work pragmatically factible.

I also thank David Lellinger, John T. Mickel, Robbin C. Moran, Benjamin Øllgaard, Else Østergaard Andersen, Carlos Sánchez, Alan R. Smith, and Brigitte Zimmer for invaluable advice and support, and the curators of the herbaria AAU, BM, G, GH, K, L, LPB, MO, NY, U, US, and Z for the loan of specimens. Gerhard Wagenitz graciously translated the Latin diagnoses. This work was conducted under the $\mathrm{PhD}$ exchange programm of the German Academic Exchange Servive (DAAD). My visit to Costa Rica was partly financed by the Organization for Tropical Studies (OTS), Michael Kessler (through a DFG grant), Peter Jørgensen, and John T. Mickel.

I thank Dr. Harald Schneider for his suggestions and insight into fern taxonomy, and Dr. Ursula Hofmann and Dr. Elena Reiner-Drehwald for their help, suggestions on the interpretation of morphological characters, and logistic help. I further thank Kerstin Bach for the technical help in making the figures, a work aided also by Lars Kautchor. Without them, I would only have incomplete figures to show the complexity of these ferns. I also thank Alexander Schmidt-Lebuhn for his help in the arduous task of correcting the format of the descriptions in the last stage of the preparation of the manuscript. The final editing of the manuscript would have been impossible without the help of Joachim Bankmann, who spent many hours at this task, never loosing his patience and good humor. Further help in deiting the manuscript was provided by Thorsten Krömer, Kerstin Veigt, Arnelida Gorrin, Antjie Seeber, and Nadjia Rusch. They helped me when I most needed help, and also great friends. Tania Sic helped with the specimen handling and the scanning of the specimens. I tank my cousin Milenka Aparicio, my friends Diana Marcano and Maria Esther Estevez with their friendship and support helped me to get through the difficult last year of finishing my thesis. Finally, I thank my family for its support and loving communication during several years of distance. 


\section{LITERATURED CITED}

Atkinson, L. R. \& A. G. Stokey. 1964. Comparative morphology of the gametophyte of the homosporous fern. Phytomorphology 14: 51-70.

Barrington, D. S., C.H. Haufler \& C. R. Werth. 1989. Hybridization, reticulation, and species concept in the ferns. Amer. Fern J. 79: 55-64.

Bernhardi, J. J. 1805. Dritter Versuch einer Anordnung der Farrnkräuter. Neues Journal für die Botanik 1: 38 .

Bierhorst, D., 1971. Soral and pinnule ontogeny in Gleichenia linearis. Amer. J. Bot. 58: 417-423.

Ching, R.C. 1940. On the genus Gleichenia Smith. Sunyatsenia Vol. 5: 269-289.

Christensen, C. 1938. Gleicheniaceae. In: Verdoorn, F. ed. Manual of Pteridology. Martius Nijhoff. The Haugue.

Chrysler, M.A., 1943. The vascular texture of the leaf of Gleichenia. I. The anatomy of the branching regions. Amer. J. Bot. 30: 735-743.

- 1944. The vascular texture of the leaf of Gleichenia. II. The petiolar bundle. Amer. J. Bot. 31: 483-491.

Copeland, E. B. 1947. Genera Filicum. Waltham, MassChronica Botanica. USA.

Diels, F. L. E. 1900. Gleicheniaceae. In Engler, A. \& K. Prantl ed. Die Natürlichen Pflanzenfamilien. Wilhelm Engemann. Leipzig. 352-356.

Duek, J. J. 1974. A newly recognized Gleichenia hybrid from Cuba. Amer. Fern J. 64: 74-80.

- 1976. Contribution of the Flora of Cuba: Osmundaceae, Schizaceae and Gleicheniaceae (Pteridophyta). Feddes Repertorium. 87: 325-360.

Gastony, G. J. \& M. D. Windham. 1989. Species concept in Pteridophytes: The treatment and definition of agamosporous. Amer. Fern J. 79: 65-77.

Hagemann, W. \& U. Schulz, 1978. Wedelangelung und Rhizomverweigung bei einigen Gleicheniaceae. Bot. Jahrb. Syst. 99: 380-399.

Haufler, C. H. \& W. W. Adams III 1982. Early gametophyte ontogeny of Gleichenia bifida (Willd.) Spreng.: Phylogenetiy and ecological implications. Amer. J. Bot. 69: 15601565 .

Haufler, C. H. 1989. Species concept in pteridophytes: Introduction. Amer. Fern J. 79: 33-35. - 1989. Species concepts in pteridophytes: Summary and synthesis. Amer. Fern J. 79: 90-93. 
- 2002. Homospory 2002: An odyssey of progress in Pteridophyte genetics and evolutionary biology. Bioscience 52: 1081- 1093.

Heer, O. 1875. Flora Fossilis Artica, III. 2. Die Kreideflora der arktischen Zone. Konigl. Svenska Vetensk. Akad. Handl. 12: 1-138.

Hickey, R. J., W. C. Taylor \& N.T. Luebke. 1989. The species concept in Pteridophyta with special reference to Isoëtes. Amer. Fern J. 79: 78-89.

Holttum, R.E. 1957. Morphology, growth-habit, and classification in the family Glelcheniaceae. Phytomorphology 2: 168-184.

- 1957. Florae Malesianae Precursores XVI: On the taxonomic subdivision of the Gleicheniaceae, with descriptions of new malaysian species and varieties. Reinwardtia 4: $257-280$.

- 1959. Gleicheniaceae. Flora Malesiana II-Pteridophyta: Gleicheniaceae, Schizaeceae and Isoetaceae. 1: 1-36.

- 1964. Distribition of some of the more primitive ferns of Mt. Kinabalu. J. Royal Society London, B. 161: 38-48.

- 1964. The evolution of the vascular system in ferns with special reference to dorsiventral rhizomes. Phytomorphology 14: 477-480.

- 1973. On the typification of Mertensia Willd. Non Roth (Gleichenaiceae) with notes on Sticherus Pres1 and Hicriopteris Presl. Taxon 22: 447-450.

Hieronymus, G. 1852. Organ für Kryptogamenkunde und Phytopatologie nebst Repertorium für Literatur. Hedwigia 24: 285-289.

Ibisch, P.L., M. Kessler, C. Nowicki \& W. Barthlott. 2000. Ecology, biogeography and diversity of the Bolivian epiphytic cacti - with the description of two new taxa. Bradleya 18: 2-30.

Jermy A.C. \& T.G. Walker. 1985. Cytotaxonomic studies of the ferns of Trinidad. Bull. Brit. Mus. Nat. Hist.(Bot.) 13: 185-191, 258-264.

Kramer, K.U. 1990. Gleicheniaceae, in ed. Kubitzki, K. The families and genera of vascular plants, I. Pteridophytes and Gymnosperms. Spring Verlag, Berlin.

Lellinger, D.B. 1989. The fern and fern allies of Costa Rica, Panama and Choco (Part I: Psilotaceae through Dicksoniaceae). Pteridologia 2A: 1-364.

- 2002. A Modern multilingual glossary for Taxonomic Pteridology. American Fern Society. Smithsonian Institution, Washington, D.C. 
Lugardon, B. 1971. Contribution à la connaissance de la morphogénèse et de la texture des parois sporales chez les Filicinées isosporées. 257 pp. PhD thesis, Paul Sabatier University, Toulouse, France.

Luckow, M. 1995. Species concepts: assumptions, methods, and applications. Syst. Bot. 20: 589-605.

Maxon, W. R. 1909. Studies of tropical American ferns, No. 2. Contr. U. S. Natl. Herb. 13.

- 1912. Studies of tropical American ferns, No. 3. Contr. U. S. Natl. Herb. 16.

- 1922. Studies of tropical American ferns, No. 7. Contr. U. S. Natl. Herb. 24.

- 1947. Puerto Rican fern notes. Proc. Biol. Soc. Wash. 60: 123-130.

- 1933. Fern miscellany, II. Proc. Biol. Soc. Wash. 46: 105-108.

Mickel, J. T. \& J. M. Beitel. 1988. Pteridophyte Flora of Oaxaca, Mexico. Memoirs of the New York Botanical Garden 46: 1-568.

Moran, R. C. 1995. Gleicheniaceae, pp. 58-62, in: G. Davidse, M. Sousa S. \& S. Knapp eds., Flora Mesoamericana Vol. 1: Psilotaceae a Salviniaceae, Universidad Nacional Autónoma de México, Missouri Botanical Garden \& The Natural History Museum, London.

Mullenniex, A. T.M. Hardig \& I.M.R. Mester. 1999. Molecular confirmation of hybrid swarms in the ferns genus Polystichum (Dryopteridaceae). Syst. Bot. 23: 421-426.

Nakai, T. 1950. A new classification of Gleicheniales. Bull. Nat. Science Museum, Tokyo 29: $1-71$.

Ortega, F. 1991. Helechos del estado Portuguesa. Biolliana, ed. especial 2: 1-155.

Østergaard, A.E. \& B. Øllgaard. 1996. A Note on some morphological terms of the leaf in the Gleicheniaceae. Amer. Fern J. 86: 52-57.

-2001. Gleicheniaceae pp. 107-169. in Harling, G. \& Andersson, L. (eds.) Flora of Ecuador. No. 66.

Palacios-Rios, M. 1992. Gleicheniaceae, Flora de Veracruz 69: 1-96.

Paris, C.A., F. S. Wagner \& W. H. Wagner, Jr. 1989. Cryptic species, species delimitation, and taxonomic practice in the homosporous Ferns. Amer. Fern J. 79: 36-45.

Pichi Sermolli, R.E. 1977. Tentamen Pteridophytorum genera in taxonomicum ordinem redigendi. Webbia 31: 313-512.

Plumier, Ch. R. P. 1703. Traite des fougeres de 1'Amerique. Paris, l'Imprimiere Royale.

Proctor, G. R. 1985. Ferns of Jamaica. British Museum (Natural History), London.

Punetha, N. 1988. Apical inhibition in the fronds of gleichenioid ferns. Phytomorphology 38: 187-192. 
Sachs, T. \& Thimann, K. V. 1964. Release of lateral buds from apical dominance. Nature 201: 939-940.

Sehnem, A. 1970. Gleicheniaceae. In Reitz R. P. (ed.) Flora Ilustrada Catarinense. Libraria Blumenauense, Brazil.

Schneider, H. 1996. Vergleichende Wurtzelanatomie der Farne. PhD thesis, Zürich University, Switzerland.

Smith, A.R. 1980. New taxa and combinations of pteridophytes from Chiapas, Mexico. Amer. Fern. J. 70: 15-27.

- 1981. Pteridophytes. In Flora de Chiapas, ed. Breedlove, D. E. California Academy of Sciences, San Francisco.

- 1985. Pteridophytes of Venezuela: an annotated list. Dept. of Botany, Herbarium, Univ.

Calif.

Snow, D. 1982. The Cotingas. Cornell Univ. Press, Ithaca, New York

Sodiro, A. S. J. 1893. Cryptogamae vasculares quitenses. Quiti Typis Universitatis.

Stokey, A.G. 1950. The gametophyte of the Gleichenaiceae. Bull Torrey Bot. Club 77: 323339.

Stolze, R.G. 1976. Ferns and ferns allies of Guatemala. Part I. Ophioglossaceae through Cyantheaceae. Fieldiana, Bot. 37: 1-98.

Sturm, J.G. 1840. Gleicheniaceae. Pages 219-238 in F.P.C. Martius, G. Eichler \& I. Urban (eds.), Flora Brasiliensis, Vol. I. München.

Troll, W. 1939. Vergleichende Morphologie der Höheren Pflanzen. I. Borntraeger. Berlin

Tryon R. M. \& Tryon R. G. 1982 Ferns and allied plants. Springer-Verlag, New York.

Tryon, A.F. \& B. Lugardon. 1990. Spores of the Pteridophyta. Springer, Berlin.

Underwood, L. M. 1907. American Ferns VIII. A preliminary review of the North American Gleicheniaceae. Bull. Torrey Bot. Club 34: 243-262.

Van den Heede, C.J., R. L. R. Viane \& N. W. Chase. 2003. Phylogeny genetic analyse of Asplenium subgen. Cterach (Pteridophyta) based of plastid and nuclear ribosomal ITS DNA sequences. Amer. J. Bot. 90: 481-495.

Vareschi, V. 1969. Los Helechos de Venezuela Vol. 1, In Flora de Venezuela, Caracas

Walker, T. G. 1985. Cytotaxonomic studies of the ferns of Trinidad 3. Descriptions of new species and hybrids and a new combination. Bull. Br. Mus. Nat. Hist. (Bot.) 13: 251276, 185-263.

Walker, T. G. \& Ortega, F. 1992. Cytotaxonomic notes on members of Venezuelan Gleicheniaceae. Fern Gazette 14:139-144. 
Wagner, W. H. Jr. 1957. Heteroblastic leaf morphology in juvenile plants of Dicranopteris linearis (Gleicheniaceae). Phytomorphology 7: 1-6.

Wagner, W. H. Jr. \& Wagner, F.S. 1983. Genus communities as a systematic tool in the study af new world Botrychium (Ophioglosaceae). Taxon 32(1): 51-63.

- 1988. The role of new methods of correlating data in pteridology. Proseeding of ISSP: 1720.

Yatskievych, G. \& R. C. Moran. 1989. Primary divergence and species concepts in ferns. Amer. Fern J. 79: 36-45. 


\section{INDEX OF SCIENTIFIC NAMES}

New names and combinations are in boldface. Synonyms are in italics. Numbers indicate the reference to the species.

Acrostichum furcatus, 24

Dicranopteris affinis, 34

Dicranopteris bifida, 1

Dicranopteris boliviensis, 41

Dicranopteris brittonii, 28

Dicranopteris costaricensis, 34

Dicranopteris cubensis, 4

Dicranopteris fulva, 8

Dicranopteris intermedia, 53

Dicranopteris jamaicensis, 38

Dicranopteris lehmannii, 47

Dicranopteris leonis, 56

Dicranopteris longipinnata, 42

Dicranopteris maritima, 12

Dicranopteris nitidula, 47

Dicranopteris orthoclada, 51

Dicranopteris palmata, 24

Dicranopteris pennigera, 36

Dicranopteris peruviana, 33

Dicranopteris pruinosa, 36

Dicranopteris pteridella, 46

Dicranopteris pubescens, 1

Dicranopteris remota, 31

Dicranopteris rubiginosa, 27

Dicranopteris simplex, 39

Dicranopteris strictissima, 30

Dicranopteris underwoodiana, 37

Dicranopteris velata, 20

Dicranopteris williamsii, 31

Dicranopteris yungensis, 40

Gleichenia affinis var. bogotensis, 34

Gleichenia affinis var. pachensis, 34

Gleichenia affinis, 34

Gleichenia axialis, 53

Gleichenia bicolor, 26

Gleichenia bifida, 1

Gleichenia blepharolepis, 18

Gleichenia bradeorum, 23

Gleichenia brevipubis, 8 
Gleichenia brittonii, 28

Gleichenia buchtienii, 16

Gleichenia compacta, 23

Gleichenia costaricensis, 34

Gleichenia dissitifolia, 51

Gleichenia farinosa, 29

Gleichenia furcata, 24

Gleichenia glaucina, 30

Gleichenia gnidioides, 49

Gleichenia gracilis, 48

Gleichenia hastulata, 52

Gleichenia hypoleuca, 47

Gleichenia intemedia var. intermedia, 53

Gleichenia interjecta, 6

Gleichenia intermedia var. dissitifolia, 51

Gleichenia intermedia var. flexuosa, 50

Gleichenia intermedia, 53

Gleichenia lanosa, 16

Gleichenia lanuginosa, 22

Gleichenia lechleri, 40

Gleichenia lehmannii, 47

Gleichenia leucocarpa, 40

Gleichenia longipes, 36

Gleichenia longipinnata, 42

Gleichenia maritima, 12

Gleichenia mathewsii, 2

Gleichenia melanoblasta, 32

Gleichenia mellifera, 23

Gleichenia nigropaleacea, 7

Gleichenia nitidula, 47

Gleichenia orthoclada, 51

Gleichenia pallescens, 26

Gleichenia palmate, 24

Gleichenia paulistana, 21

Gleichenia pennigera var. lanuginosa, 22

Gleichenia pennigera, 36

Gleichenia peruviana, 33

Gleichenia pruinosa, 36

Gleichenia pteridella, 46

Gleichenia pubescens var. Blepharolepis, 18

Gleichenia pubescens, 1

Gleichenia remota, 31

Gleichenia retroflexa, 50

Gleichenia revoluta, 34

Gleichenia rubiginosa, 27

Gleichenia simplex, 39

Gleichenia strictissima, 30

Gleichenia subandina, 34

Gleichenia tomentosa, 15

Gleichenia trachyrhizoma, 31 
Gleichenia trachyrhizoma, 53

Gleichenia velata, 20

Gleichenia x leonis, 56

Gleichenia x pseudobifidus, 54

Gleichenia x subremota, 55

Gleichenia yungensis, 40

Mertensia angusta, 36

Mertensia bifida, 1

Mertensia decurrens, 2

Mertensia farinosa, 29

Mertensia ferruginea, 3

Mertensia fulva, 8

Mertensia furcata, 24

Mertensia gracilis, 48

Mertensia longipes, 36

Mertensia longipinnata, 42

Mertensia mathewsii, 2

Mertensia nigropaleacea, 7

Mertensia nuda, 43

Mertensia palmate, 24

Mertensia pennigera, 36

Mertensia pruinosa, 36

Mertensia pubescens, 1

Mertensia remota, 31

Mertensia revoluta, 34

Mertensia simplex, 39

Mertensia squamosa, 21

Mertensia subtrisperma, 29

Mertensia tomentosa, 15

Mertensia trifurcans, 2

Mertensia velata, 20

Sticherus affinis, 34

Sticherus albus, 25

Sticherus arachnoideus, 14

Sticherus aurantiacus, 11

Sticherus bifidus, 1

Sticherus blepharolepis, 18

Sticherus boliviensis, 41

Sticherus brevipubis, 8

Sticherus brevitomentosus, 45

Sticherus brittonii, 28

Sticherus buchtienii, 16

Sticherus chocoensis, 5

Sticherus compactus, 23

Sticherus costaricensis, 34

Sticherus cubensis, 4

Sticherus decurrens, 2

Sticherus farinosus, 29 
Sticherus ferrugineus x Sticherus furcatus, 59

Sticherus ferrugineus, 3

Sticherus fulvus x S. retroflexus, 60

Sticherus fulvus, 8

Sticherus furcatus, 24

Sticherus fuscus, 9

Sticherus gnidioides $\mathrm{x}$ Sticherus pteridellus, 57

Sticherus gnidioides, 49

Sticherus gracilis, 48

Sticherus hastulatus, 52

Sticherus hispaniolensis, 17

Sticherus hypoleucus, 47

Sticherus interjectus, 6

Sticherus intermedius, 53

Sticherus jacha, 19

Sticherus jamaicensis, 38

Sticherus lanosus, 16

Sticherus lanuginosus, 22

Sticherus lechleri, 40

Sticherus lehmannii, 47

Sticherus leucocarpus, 40

Sticherus longipinnatus, 42

Sticherus maritimus, 12

Sticherus mathewsii, 2

Sticherus melanoblastus x Sticherus tomentosus, 61

Sticherus melanoblastus, 32

Sticherus mellifer, 23

Sticherus nervatus, 35

Sticherus nigropaleaceus, 7

Sticherus nitidulus, 47

Sticherus nudus, 43

Sticherus orthocladus, 51

Sticherus ovatus, 44

Sticherus pallescens, 26

Sticherus palmatus, 24

Sticherus paulistanus, 21

Sticherus penniger, 36

Sticherus peruvianus, 33

Sticherus pruinosus, 36

Sticherus pteridellus, 46

Sticherus pubescens, 1

Sticherus remotus, 31

Sticherus retroflexus, 50

Sticherus revolutus, 34

Sticherus rubiginosus, 27 
Sticherus rufus, 13

Sticherus simplex x Sticherus revolutus, 62

Sticherus simplex, 39

Sticherus squamosus, 21

Sticherus strictissimus, 30

Sticherus subandinus, 34

Sticherus tepuiensis, 10

Sticherus tomentosus, 15

Sticherus underwoodianus, 37

Sticherus velatus, 20

Sticherus x leonis, 56

Sticherus x pseudobifidus, 54

Sticherus x subremotus, 55

Sticherus yungensis, 40 